Gospodarowanie zasobami finansowymi w polskim samorządzie terytorialnym 
蓄 
Ekonomia

\section{Gospodarowanie zasobami finansowymi w polskim samorządzie terytorialnym}

Zofia Dolewka 
Zofia Dolewka - Uniwersytet Łódzki, Wydział Ekonomiczno-Socjologiczny Instytut Gospodarki Przestrzennej, Katedra Gospodarki Samorządu Terytorialnego 90-255 Łódź, ul. POW 3/5

\author{
RECENZENT \\ Krzysztof Kluza \\ REDAKTOR INICJUJĄCY \\ Beata Koźniewska \\ REDAKCJA \\ Dominika Rafa
SKŁAD I ŁAMANIE AGENT PR \\ PROJEKT OKŁADKI \\ AGENT PR \\ Beata Chruścicka
}

(c) Copyright by Zofia Dolewka, Łódź-Kraków 2020

(c) Copyright for this edition by Uniwersytet Łódzki, Łódź-Kraków 2020

(C) Copyright for this edition by AGENT PR, Łódź-Kraków 2020

Wydane przez Wydawnictwo Uniwersytetu Lódzkiego

Wydanie I. W.10130.20.0.M

Ark. wyd. 10,5, ark. druk. 10,375

ISBN 978-83-8220-463-6

e-ISBN 978-83-8220-464-3

ISBN AGENT PR 978-83-64462-78-8

https://doi.org/10.18778/8220-463-6

Wydawnictwo Uniwersytetu Łódzkiego

90-131 Łódź, ul. Lindleya 8

www.wydawnictwo.uni.lodz.pl

e-mail: ksiegarnia@uni.lodz.pl

tel. 426655863 


\section{Spis treści}

Wprowadzenie

Rozdział I

Pojęcia podstawowe i uwagi interpretacyjne

Rozdział II

Samorząd terytorialny jako system gospodarowania i zarządzania

Rozdział III

Specyfika gospodarki samorządu Implikacje ekonomiczne

Rozdział IV

Zarządzanie finansami a proces decyzyjny

Rozdział V

Finansowanie zadań publicznych

Rozdział VI

Budżet jako podstawa wykonywania zadań publicznych

Rozdział VII

Kwestia samodzielności finansowej

Rozdział VIII

Utrzymanie majątku komunalnego i jego rozwój

Rozdziat IX

Finansowanie dziatalności rozwojowej Rola nadwyżki operacyjnej 
Rozdziat XI

Kadencyjność organów a planowanie spłaty długu w czasie

Rozdział XII

Diagnoza sytuacji finansowej jednostek samorządowych

Rozdział XIII

Planowanie długofalowe. Wieloletnia prognoza finansowa

Rozdział XIV

Problem przejrzystości gospodarki finansowej

Rozdział XV

Podstawowe mierniki badania sytuacji finansowej jednostek samorządowych

Rozdział XVI

UŻyteczność polityczna i społeczna raportu o stanie jednostki samorządowej 127

Rozdział XVII

Kierunki zmian systemowych i usprawniających 131

Zakończenie

Bibliografia

Załączniki

Spis tabel 


\section{Wprowadzenie}

Problematyka finansów samorządu terytorialnego jest silnie uwarunkowana przepisami prawa. Regulacje prawne są różnorodne i obejmują akty najwyższej rangi (Europejska Karta Samorządu Lokalnego ${ }^{1}$, Konstytucja $R P^{2}$ - jako ustawa zasadnicza, pozostałe ustawy). Drugą grupę tworzą rozporządzenia, czyli akty wykonawcze do ustaw, a następnie akty prawa miejscowego (uchwały, zarządzenia). Dokumenty prawne zakreślają ramy i podstawowe ustalenia, dotyczące problematyki finansów samorządowych. $Z$ tego względu, wprowadzają duży formalizm do procesów decyzyjnych, rodzących skutki finansowe. Formalizm ten tworzy określony reżim, rygory, zasady i procedury postępowania w związku z gromadzeniem i rozdysponowaniem zasobów finansowych w strukturach jednostek samorządu terytorialnego.

Wiedza o procesach i zjawiskach tworzących gospodarkę finansową w samorządzie terytorialnym jest nadal mało stabilna i w wielu miejscach niepełna. Realna gospodarka finansowa samorządu stanowi odbicie procesu zaspokajania potrzeb społecznych w kontekście rozwoju jednostki samorządowej. Odbywa się to dzięki procesom zarządzania publicznego, w celu dokonania przekształceń gospodarczych dla poprawy warunków życia mieszkańców. Na kształt gospodarki finansowej samorządu istotny wpływ miało też przystąpienie Polski w 2004 r. do Unii Europejskiej (UE), które przyniosło dwie konsekwencje. Pierwszą była i jest możliwość pozyskania części środków finansowych dla zrealizowania wielu przedsięwzięć gospodarczych. Druga konsekwencja akcesji polega na dostosowaniu się do zasad i standardów określonych przez struktury unijne (np. gospodarka odpadami, polityka energetyczna), co prowadzi do wzrostu kosztów działalności. Zaległości cywilizacyjne, różny stopień zaspokajania potrzeb publicznych poprzez świadczenie usług, procesy demograficzne, rozwiązania systemowe oraz różna jakość zarządzania sprawiają, że występuje istotne zróżnicowanie samorządów terytorialnych pod względem majątkowym, dochodowym, infrastrukturalnym, rozwoju przedsiębiorczości itp.

1 Europejska Karta Samorzq̨du Lokalnego sporządzona w Strasburgu dnia 15 października 1985 r. (Dz. U. z 1994 r. Nr 124, poz. 607 ze zm.). Dalej będzie mowa o EKSL.

2 Konstytucja Rzeczypospolitej Polskiej z dnia 2 kwietnia 1997 r. (Dz. U. z 1997 r. Nr 78, poz. 483 ze zm.). 
Obecnie funkcjonujący system finansowy samorządu terytorialnego zawiera dużo ułomności i dysfunkcji. Ich konsekwencją jest przede wszystkim niedobór środków, wynikający m.in. z braku przestrzegania zasady adekwatności i potencjalnego zagrożenia stabilności finansów samorządowych. Uzasadnia to konieczność przebudowy finansów samorządu w Polsce, w kierunku zmian systemowych i usprawniających. Na potrzebę tych zmian wskazują prawie wszyscy specjaliści zajmujący się zagadnieniami finansów samorządowych, z teoretycznego i praktycznego punktu widzenia. Wpływ różnych czynników na gospodarkę samorządu powoduje także (podkreślane wcześniej) zróżnicowanie finansowe poszczególnych jednostek, które w skrajnej, negatywnej formie wyrażają się w:

- zbyt dużym wysiłku inwestycyjnym przy wadliwie określonych priorytetach rozwojowych,

- nadmiernym zadłużeniu (m.in. wystąpienie tzw. pętli zadłużenia, bądź forsownej wyprzedaży majątku komunalnego),

- ryzyku utraty płynności finansowej,

- wykonywaniu zadań publicznych w warunkach koncentracji uwagi na spłacie zaciągniętych zobowiązań długoterminowych, co może skutkować przerwaniem ciągłości świadczenia usług lub rażącym obniżeniem ich jakości (przez programy naprawcze).

Zasygnalizowane powyżej kwestie uzasadniają permanentne zainteresowanie badawcze, zarówno na gruncie teoretyczno-poznawczym, jak i praktycznym. Analiza i ocena zmian zachodzących w gospodarce finansowej samorządów jest istotna i potrzebna, w świetle różnych ocen dotyczących kondycji ekonomicznej oraz finansowej tych jednostek.

Celem opracowania jest specyfikacja podstawowych problemów $i$ wyzwań $w$ dziedzinie finansów lokalnych, identyfikacja czynników determinujących przebieg gospodarki finansowej oraz zaproponowanie zbioru rozwiązań, zwiększajacych efektywność formułowanych ocen finansowych. Zamysłem autorki było nie tylko przeprowadzenie opisu i wyjaśnianie pewnych zagadnień gospodarki finansowej samorządu, lecz zwrócenie szczególnej uwagi na interakcje i wzajemne zależności między różnymi obszarami działalności gospodarczej, przynoszące konsekwencje ekonomiczne. Związki te powinny być brane pod uwagę w procesie decyzyjnym, dotyczącym gospodarki finansowej samorządu. W procedurze badawczej przyjęto wspólny mianownik, że podjęte w analizie i ocenie kwestie szczegółowe w zakresie finansów lokalnych, są mocno zakorzenione w praktyce gospodarczej. Autorka postawiła następującą tezę badawczą: dysfunkcje w gospodarce finansowej samorządu terytorialnego wynikaja nie tylko z niedoboru środków finansowych na zadania własne i zlecone oraz z wadliwego sposobu zarzadzania zasobami majątkowymi, ale również z nieadekwatności źródet dochodów przypisanych jednostkom samorzadu do przekazanych im zadań publicznych.

Punktem wyjścia do rozważań było przyjęcie trzech założeń, pozwalających zakreślić merytoryczny zakres prowadzonej analizy i skonkretyzować podejmowane kwestie. Pierwsze założenie polega na stwierdzeniu, że w istniejącym systemie 
prawnym regulującym planowanie finansowe tkwią już pewne błędy, powodujące nieracjonalność podejmowanych decyzji finansowych. Drugie założenie dotyczy oczywistego powiązania już na etapie planowania, poniesionych nakładów finansowych z oczekiwanymi efektami rzeczowymi. Trzecie założenie odnosi się do istotnego zjawiska w samorządzie, jakim jest nakładanie się wielkości zadłużenia w cyklu inwestycyjnym i w cyklu politycznym (kadencja władz). Odnosząc się już w tym miejscu do przyjętych założeń badawczych można stwierdzić ad hoc, że usunięcie mankamentów stąd płynących, będzie wymagać zmian w porządku prawnym, w celu ich wyeliminowania.

Konstrukcja i struktura pracy wynika z założeń oraz przyjętego celu badania. Opracowanie rozpoczyna wprowadzenie, które ma charakter metodyczny. W książce zawarte są trzy przekroje analizy. Pierwszy przedstawia wyjaśnienie podstawowych pojęć z zakresu finansów lokalnych oraz gospodarkę finansową w kontekście samorządu terytorialnego (punkty 2-6), drugi charakteryzuje i analizuje podstawowe komponenty składające się na system finansowy samorządu (7-11). Ostatni zaś prezentuje opis wybranych zasad i zakresów oceny finansowej (12-17). Pracę kończy sformułowanie kierunków niezbędnych zmian oraz syntetyczne zakończenie. Materiał faktograficzny zawarty w pracy pochodził z następujących źródeł: literatury przedmiotu, przepisów prawa, sprawozdań budżetowych, statystyki publicznej, raportów i opracowań specjalistycznych, stron internetowych samorządów oraz doświadczenia praktycznego autorki. W pracy wykorzystano zbiór metod badawczych, takich jak: krytyczna analiza i ocena regulacji prawnych, przegląd i analiza literatury dotyczącej samorządu terytorialnego oraz jego gospodarki, jak też piśmiennictwa dotyczącego finansów lokalnych, metoda analizy opisowej oraz metody poznania empirycznego, a w szczególności obserwacja, porównanie i pomiar. Rozważania są mocno osadzone w doświadczeniach praktyki gospodarczej (samorządowej). Z tego powodu prowadzone wywody nawiązują często do wcześniejszych stwierdzeń, prezentujących rozwiązania wprowadzone w życie.

Książka dotyczy problematyki gospodarki i polityki finansowej w jednostkach samorządu terytorialnego w Polsce. Pierwszym zamiarem niniejszej pracy było rozpoznanie mechanizmów kierujących procesem gromadzenia i wydatkowania środków finansowych w samorządzie. Drugim zamiarem było zaproponowanie rozwiązań, służących praktyce gospodarczej. Książka jest adresowana do szerokiego kręgu odbiorców, w pierwszym rzędzie do badaczy tej tematyki, polityków, pracowników administracji publicznej, studentów uczelni wyższych oraz tych wszystkich, którzy chcą posiąść wiedzę z dziedziny finansów lokalnych. W przekonaniu autorki niektóre wątki analityczne w rozważaniach mogą stać się przedmiotem odrębnego i bardziej pogłębionego studiowania problemu, ze względu na ich złożony i dyskusyjny charakter (np. kwestia finansowania budownictwa komunalnego przez gminy). 



\section{Rozdział I}

\section{Pojęcia podstawowe i uwagi interpretacyjne}

W analizie i ocenie gospodarki oraz polityki finansowej w samorządzie terytorialnym stosowany jest dość obszerny aparat pojęciowy. Dużo terminów wywodzi się $z$ różnych dyscyplin naukowych, wiele z nich używa się jako zamienników, a znaczna część $\mathrm{z}$ nich jest niejednoznacznie rozumiana $\mathrm{w}$ interpretacji procesów i zjawisk finansowych w samorządzie. Dla stworzenia uproszczonej choć wykładni, najczęściej wykorzystywanych terminów, traktowanych dalej jednoznacznie i czytelnie, zasadny jest przegląd i odniesienie się do podstawowych pojęć używanych w niniejszym opracowaniu.

Gospodarka finansowa w samorządzie obejmuje zespół procesów i zjawisk związanych z przepływem i podziałem środków finansowych, w ramach realizacji zadań własnych. Skupia zatem wszystkie czynności związane z planowaniem, organizacją, realizacją, kontrolą i nadzorem w zakresie gromadzenia oraz wydatkowania środków budżetowych. Polityka finansowa samorządu oznacza świadomą i celową działalność jego organów, polegającą na wyborze (określeniu) celów i zadań społeczno-ekonomicznych oraz ich osiąganiu poprzez dobór środków i metod realizacyjnych. Według E. Ruśkowskiego, polityka finansowa to świadoma i celowa działalność ludzi i instytucji, polegająca na ustaleniu i realizowaniu określonych celów, za pomocą środków finansowych ${ }^{1}$. Stan gospodarki samorządowej znajduje odbicie w sytuacji społeczno-ekonomicznej, obrazującej jej kondycję. Mimo iż prawo zobowiązuje samorządy do racjonalnego gospodarowania środkami budżetowymi to praktyka dowodzi, że występuje wiele niegospodarności i marnotrawstwa w wykorzystaniu pieniędzy publicznych.

Finanse publiczne stanowią jeden z podstawowych elementów systemu finansowania $\mathrm{w}$ gospodarce każdego państwa ${ }^{2}$. Polegają na gromadzeniu środków finansowych, ich podziale (rozdysponowaniu) i wydatkowaniu przez różne podmioty,

1 E. Ruśkowski, Finanse i prawo finansowe, Wydawnictwo „KiK”, Warszawa 1994, s. 261.

2 B. Guziejewska, Finanse publiczne wobec wyzwań globalizacji, Wydawnictwo Poltext, Warszawa 2010, s. 19. 
w celu zaspokajania zbiorowych potrzeb społecznych. Podobnie S. Owsiak, finanse definiuje jako procesy związane z powstawaniem i rozdysponowaniem środków ${ }^{3}$. Finanse samorządowe można definiować w ujęciu węższym i szerszym ${ }^{4}$. W ujęciu węższym rozpatrujemy je zgodnie z podziałem terytorialnym państwa, czyli finanse lokalne i finanse regionalne. $Z$ kolei w ujęciu szerszym są nimi procesy związane z gromadzeniem i wydatkowaniem środków finansowych, ujętych w planie finansowym danej jednostki samorządowej. Finanse samorządowe stanowią istotny element finansów publicznych (państwa) zarówno w ujęciu zadaniowym, jak i finansowym ${ }^{5}$. Finanse lokalne są obszarem, w którym znajdują odbicie rezultaty niesprawnego zarządzania, a jednocześnie to, co się w nim dzieje wpływa na wszystkie inne dziedziny gospodarki samorządu. Zwartą definicję finansów samorządowych podaje B. Filipiak, która w szerszym ujęciu traktuje finanse jako procesy gromadzenia i wydatkowania publicznych środków finansowych jednostek samorządu terytorialnego ${ }^{6}$. Autorka utożsamia finanse samorządowe z finansami lokalnymi (powiatu i gminy).

Na system finansowy samorządu składa się zbiór zasad, procedur i rozwiązań prawnych, regulujących mechanizm funkcjonowania jego władz i administracji $\mathrm{w}$ sferze finansowej. Pojęcie systemu finansowego traktowane jest $\mathrm{w}$ książce zamiennie $\mathrm{z}$ ustrojem finansowym. Mechanizm finansowania to inaczej system funkcjonowania finansów samorządu terytorialnego. Dokumenty opisujące ustrój finansowy samorządu tworzą podstawy gospodarki samorządu oraz stanowią narzędzia wykorzystywane $\mathrm{w}$ prowadzeniu polityki finansowej przez jego organy. System finansów samorządu to inaczej całokształt zasad i instytucji oraz procedur, dotyczących gromadzenia i wydatkowania zasobów pieniężnych jednostek samorządu terytorialnego ${ }^{7}$.

Budżet jednostki samorządowej jest centralną kategorią ekonomiczną w gospodarce finansowej. Jest rocznym planem finansowym, obejmującym cztery podstawowe kategorie finansów: dochody i wydatki oraz przychody i rozchody. Na jego podstawie prowadzona jest gospodarka środkami finansowymi w ramach klasyfikacji budżetowej ${ }^{8}$. Jest on praktycznym wyrazem celów społecznych, ekonomicznych i ekologicznych, które przekształcono w konkretne, liczbowo wyrażone zadania9. W ujęciu C. Kosikowskiego, budżet jest „scentralizowanym zasobem

3 S. Owsiak, Finanse publiczne. Teoria i praktyka, Wydawnictwo Naukowe PWN, Warszawa 1999, s. 19.

4 C. Kosikowski, Finanse lokalne. Zarys wykładu, Wyższa Szkoła Finansów i Zarządzania w Siedlcach, Siedlce 2001, s. 11.

5 B. Filipiak, Finanse samorzq̨dowe. Nowe wyzwania bieżące i perspektywiczne, Wydawnictwo Difin 2011, s. 25.

6 Ibidem, s. 21.

7 Z. Strzelecki (red.), Gospodarka lokalna i regionalna, Wydawnictwo Naukowe PWN, Warszawa 2008, s. 243.

8 S. Owsiak, Finanse publiczne. Teoria i praktyka, Wydawnictwo Naukowe PWN, Warszawa 2005, s. 144.

9 A. Harańczyk, Samorząd terytorialny. Organizacja i gospodarka, Wydawnictwo Uniwersytetu Ekonomicznego w Krakowie, Kraków 2010, s. 82. 
środków pieniężnych, które państwo gromadzi i wykorzystuje w sposób planowy na realizację swoich powinności i wynikających $z$ nich zadan" 10 .

$\mathrm{W}$ ustawie o finansach publicznych $\mathrm{z} 2009 \mathrm{r}{ }^{11}{ }^{1}, \mathrm{w}$ ramach racjonalizacji gospodarki środkami publicznymi, wprowadzono regulacje zobowiązujące władze samorządu terytorialnego do uchwalania dokumentów w zakresie planowania wieloletniego. Po raz pierwszy, obowiązek opracowania wieloletniej prognozy finansowej (WPF) miał miejsce pod koniec $2010 \mathrm{r}^{12}$ Trzeba dodać, że planowanie wieloletnie jest niezbędnym narzędziem nowoczesnego zarządzania finansami publicznymi ${ }^{13}$. Mechanizm planowania w perspektywie kilku lat funkcjonuje w wielu samorządach m.in. takich krajów jak: Dania, Belgia, Portugalia, Nowa Zelandia, Stany Zjednoczone.

Zasady budżetowe traktowane są jako standardy (normy), które należy przestrzegać w gospodarce i polityce finansowej samorządu. Oznaczają one schemat postępowania, związany z gromadzeniem i rozdysponowaniem zasobów finansowych na różne konkurencyjne cele. Większość tych zasad została zapisana w regulacjach prawnych (w ustawach oraz w rozporządzeniach). Procedury budżetowe wyznaczają sformalizowany tok postępowania oparty o określoną sekwencję czynności w procesie planowania, uchwalania dokumentów finansowych, wykonywania budżetu oraz sprawowania nadzoru i kontroli w tym zakresie.

Cele i zadania finansowe - cele finansowe są decyzjami o charakterze kierunkowym, które polegają na określeniu wielkości ekonomicznych przyjętych do wykonania $\mathrm{w}$ odpowiednim horyzoncie czasowym. $\mathrm{Z}$ kolei zadania finansowe stanowią konkretyzację celów w bardziej sprecyzowanym zakresie działania. Można przyjąć, że zadania finansowe mogą być odpowiednikiem celów finansowych w wymiarze szczegółowym.

Nakłady i koszt finansowy to nakłady finansowe obrazujące wielkość zasobów finansowych, wykorzystanych dla realizacji przyjętych celów (efektów). W sensie rzeczowym, nakłady finansowe odzwierciedlają zużycie czynnika wytwórczego lub usługowego. W wyrażeniu pieniężnym odbiciem nakładów finansowych jest koszt finansowy poniesiony w procesie świadczenia usług publicznych. Potencjał finansowy samorządu oznacza zdolność jego organów do tworzenia i podziału zasobów finansowych. Na ogół przyjmuje się, że o wielkości takiego potencjału decyduje wielkość i struktura budżetu jednostki samorządowej oraz umiejętność skutecznego zarządzania poszczególnymi składnikami tego budżetu. Istotny w tym jest również poziom spłat już zaciągniętych zobowiązań, w tym kredytów

10 C. Kosikowski, Pojęcie i charakter prawny budżetu państwa, [w:] Finanse publiczne i prawo finansowe, (red.) C. Kosikowski, E. Ruśkowski, Wydawnictwo Wolters Kluwer business, Warszawa 2008, s. 301-302.

11 Ustawa z dnia 27 sierpnia 2009 r. o finansach publicznych (tekst jednolity: Dz. U. z 2019 r. poz. 869 ze zm.).

12 Nie później niż uchwałę budżetową na 2011 r.

13 Jego atuty akcentowane były w raportach i opracowaniach takich instytucji jak: Bank Światowy, Organizacja Współpracy Gospodarczej i Rozwoju (OECD). 
i pożyczek, oraz wykupu papierów wartościowych i wydatków na obsługę już zaciągniętych zobowiązań ${ }^{14}$.

Efekty ekonomiczne obrazują dokonania i osiągnięcia, w wyniku polityki gospodarczej samorządu. Natomiast efekty społeczne są niejako efektami pochodnymi i konsekwencją realizacji celów ekonomicznych. Najpełniejszym efektem społecznym jest odczuwalna poprawa standardu życia mieszkańców samorządu terytorialnego. Instrumenty finansowe to inaczej narzędzia niezbędne w gospodarowaniu zasobami finansowymi w celu ich racjonalnego wykorzystania. Środki finansowe z punktu widzenia gospodarki samorządowej są zasobami, funduszami, nakładami niezbędnymi dla procesu realizacji zadań publicznych. Czynnik polityczny w samorządzie obejmuje radnych i organy wykonawcze (zarządy, wójtów, burmistrzów i prezydentów miast) oraz niektóre stanowiska kierownicze w urzędzie (np. sekretarz, skarbnik, dyrektor departamentu, kierownik komórki organizacyjnej urzędu). Kadencyjność samorządu dotyczy okresu sprawowania władzy przez jego organy.

Rozwój jednostki samorządowej stanowi cel jej funkcjonowania, czyli mówiąc inaczej rozwój społeczny, polegający na poprawie warunków życia mieszkańców. Przez rozwój samorząu należy rozumieć pozytywne zmiany o charakterze ilościowym (wzrost gospodarczy, ludnościowy) oraz o charakterze jakościowo-strukturalnym. Drogą do tego jest działalność inwestycyjna, rozumiana tradycyjnie jako korzystna zmiana majątkowa lub współcześnie, jako wykorzystanie zasobu gospodarczego, posiadającego tę szczególną właściwość, że generuje on tzw. wartość dodaną. Zgodnie z koncepcją public governance, wartością dodaną jest wartość publiczna dla mieszkańców wspólnoty samorządowej. W szerokim ujęciu zaangażowanie inwestycyjne obejmuje również działania podmiotów prywatnych na skutek zachęt publicznych.

Gospodarowanie i zarządzanie finansami w samorządzie są procesami stanowiącymi dwie strony procesu świadczenia usług publicznych ${ }^{15}$. Gospodarowanie finansami dotyczy transformacji ograniczonych zasobów finansowych $\mathrm{w}$ podaż usług, zaspokajających potrzeby społeczne mieszkańców. Usługi te są bezpośrednimi efektami tego procesu, które następnie uruchamiają efekty pochodne. Warto zauważyć, że na gruncie nauk ekonomicznych gospodarowanie oznacza proces dokonywania wyboru (podejmowania decyzji), zdeterminowany z jednej strony nieograniczonymi potrzebami człowieka, z drugiej zaś ograniczonymi możliwościami (zasobami ekonomicznymi), według kryterium optymalizacji korzyści, jakie wiążą się z tymi decyzjami ${ }^{16}$. Cz. Rudzka-Lorentz i J. Sierak, traktują

14 E. Gubernat-Ulatowski, Potencjat finansowy i inwestycyjny a aktywność inwestycyjna jednostek samorzqdu terytorialnego, ,Zeszyty Naukowe Uniwersytetu Ekonomicznego w Katowicach", nr 294, Katowice 2016, s. 50.

15 E. Wojciechowski, Gospodarka samorządu terytorialnego, Wydawnictwo Difin, Warszawa 2012, s. 68.

16 Zob. E. Taylor, Historia rozwoju ekonomiki, t. 1, Państwowe Wydawnictwo Naukowe, Warszawa 1957; W. Wilczyński, Rachunek ekonomiczny a mechanizm rynkowy, Państwowe Wydawnictwo 
zarządzanie finansami gminy jako proces polegający na podejmowaniu przez organy władzy działań oraz decyzji, służących maksymalizacji ekonomicznych i społecznych efektów, zgodnie z przyjętymi celami ${ }^{17}$.

Sytuacja finansowa samorządu oznacza stan jego gospodarki w wymiarze finansowym. Jest to inaczej obraz kondycji finansowej, podlegającej ocenie (standing finansowy). Kondycja finansowa odzwierciedla stan finansów samorządu w określonym czasie, który jest wynikiem posiadanych dochodów i wydatków oraz ich struktury, stopnia wykorzystania środków zwrotnych, aktywności i skuteczności w pozyskiwaniu środków pozabudżetowych, a także sprawności ogólnego zarządzania posiadanymi zasobami finansowymi i rzeczowymi ${ }^{18}$. Ocenę finansową może przeprowadzać podmiot wewnętrzny (służby finansowe samorządu podległe skarbnikowi, audytorzy wewnętrzni) lub podmioty zewnętrzne o uprawnieniach nadzorczo-kontrolnych (regionalne izby obrachunkowe, Najwyższa Izba Kontroli), bądź wyspecjalizowane agencje rynkowe (analizy, raporty, sporządzanie ratingów). Zdaniem J. Sieraka wyniki analiz finansowych stanowią pewne wyzwania dla władz lokalnych, bowiem stymulują do myślenia opartego na logice ekonomicznej oraz sprzyjają pogłębianiu oceny gospodarki i polityki finansowej ${ }^{19}$. Ocena kondycji finansowej jest formą diagnozy, pozwalającej doskonalić proces decyzyjny w kierunku poprawy efektywności gospodarowania zasobami majątkowymi.

Naukowe, Warszawa 1965; S. Czaja, A. Becla, Ekologiczne podstawy procesów gospodarowania, Wydawnictwo Akademii Ekonomicznej we Wrocławiu, Wrocław 2007; B. Czarny, Podstawy ekonomii, Polskie Wydawnictwo Ekonomiczne, Warszawa 2011; P. Krugman, R. Wells, Mikroekonomia, Wydawnictwo Naukowe PWN, Warszawa 2013; T. Kudłacz, Finansowe aspekty polityki przestrzennej samorządów terytorialnych, [w:] Zrozumieć terytorium. Idea i praktyka, (red.) A. Nowakowska, Wydawnictwo Uniwersytetu Łódzkiego, Łódź 2013.

17 Cz. Rudzka-Lorentz, J. Sierak, Zarzq̨dzanie finansami w gminach, [w:] Zarzq̨dzanie gospodarka i finansami gmin, (red.) H. Sochacka-Krysiak, Szkoła Główna Handlowa w Warszawie, Warszawa 2006, s. 183.

18 A. Standar, Ocena kondycji finansowej gmin oraz jej wybranych uwarunkowań na przykładzie województwa wielkopolskiego przy wykorzystaniu metody TOPSIS, „Wieś i Rolnictwo” 2017, nr 2, s. 69-92.

19 J. Sierak, Regionalne zróżnicowanie wielkości i dynamiki dochodów gmin i miast na prawach powiatu - analiza wskaźnikowa dla lat 2000-2014, „Finanse Komunalne” 2017, nr 1-2, s. 77. 



\section{Rozdział II}

\section{Samorząd terytorialny jako system gospodarowania i zarządzania}

Na gospodarkę finansową samorządu należy patrzeć z szerszej perspektywy, którą określają dwie zasady: decentralizacji i pomocniczości (subsydiarności). Decentralizacja stanowi ogólny trend w zapewnieniu wyższej sprawności działania, w tym efektywności ekonomicznej. Podstawą reformy państwa jest decentralizacja, jako proces przekazywania zadań, środków i uprawnień decyzyjnych, z wyższego do niższego szczebla w systemie organizacji państwa. Ten kierunek zmian zawarty jest w Konstytucji RP oraz w EKSL. Szerszy przegląd pojęcia decentralizacji prezentuje Ryszard P. Krawczyk ${ }^{1}$. Z kolei, H. Sochacka-Krysiak zwraca uwagę na dwa rodzaje decentralizacji: terytorialną i funkcjonalną. Pierwsza dotyczy przekazywania zadań publicznych i środków finansowych jednostkom samorządu terytorialnego. Druga polega na delegowaniu zadań i władzy na niższe poziomy zarządzania w ramach wyodrębnionych struktur organizacyjnych ${ }^{2}$. Zasadę pomocniczości (zawartą w preambule Konstytucji $R P$ i w regulacjach traktatowych Unii Europejskiej) należy rozumieć w dwojaki sposób. Po pierwsze, jako rezultat podziału władzy i administracji publicznej z wydzieleniem sektora samorządu terytorialnego. Po drugie, jako lokowanie decyzji publicznych na tym szczeblu kierowania sprawami publicznymi, który znajduje się najbliżej potrzeb obywatela. Obydwie zasady stanowią generalny standard działania w sferze publicznej i są kontekstem dla gospodarki finansami lokalnymi.

$\mathrm{Na}$ ogół samorząd terytorialny jest traktowany jako układ i forma wykonywania administracji publicznej w postaci zdecentralizowanej. W związku z tym

1 Ryszard P. Krawczyk, Samodzielność w praktyce działania samorządu terytorialnego oraz w orzecznictwie Trybunatu Konstytucyjnego, [w:] Aktualne problemy samorzadu terytorialnego po 25 latach jego istnienia, (red.) Ryszard P. Krawczyk, A. Borowicz, Wydawnictwo Uniwersytetu Łódzkiego, Łódź 2016, s. 46-47.

2 H. Sochacka-Krysiak, Decentralizacja terytorialna w świetle Europejskiej Karty Samorzq̨u Terytorialnego [w:] Gospodarka finansowa jednostek samorzadu terytorialnego w warunkach decentralizacji zarządzania sektora publicznego, (red.) H. Sochacka-Krysiak, Szkoła Główna Handlowa w Warszawie, Warszawa 2008, s. 101. 
w analizie samorządu dominuje problematyka prawno-administracyjna i organizacyjna. Od samego początku reaktywowania instytucji samorządu terytorialnego podkreślany jest jego korporacyjny charakter w sensie prawa, a co za tym idzie formalna interpretacja zachodzących procesów i zjawisk. Tymczasem, samorząd posiada widoczny wymiar ekonomiczny, który determinują dwa kolejne agregatowe procesy: gospodarowanie i zarządzanie. Tworzą one systemy, w których odbywa się realizacja zadań publicznych $\mathrm{w}$ celu zaspokajania zbiorowych potrzeb publicznych. Żadne regulacje prawne nie charakteryzują samorządu w kategoriach podmiotu gospodarczego. $\mathrm{Z}$ punktu widzenia ekonomicznego, samorząd i jego gospodarka tworzą instytucję publiczną dysponującą zasobami, które należy racjonalnie wykorzystywać w dobrze pojętym interesie publicznym, czyli jego mieszkańców. Pod pewnymi względami samorząd terytorialny posiada cechy typowe dla organizacji gospodarczej (spółki kapitałowej). Do kluczowych cech należy zaliczyć:

- podstawowe elementy struktury działania,

- dysponowanie zasobami gospodarczymi, których efektywne wykorzystanie zależy od metod i technik zarządzania zaczerpniętych z sektora prywatnego.

$\mathrm{W}$ samorządzie, podobnie jest $\mathrm{w}$ spółce, odpowiednikiem udziałowców (shareholders) jest ogół mieszkańców określonej wspólnoty. Swoistą „radą nadzorczą" w samorządzie staje się organ stanowiący, grupujący wybranych przedstawicieli (radnych), mających reprezentować interesy różnych grup społecznych i zawodowych. Funkcje zarządu spółki kapitałowej, w samorządzie realizuje jego organ wykonawczy, który może być kolegialny (zarząd powiatu, zarząd województwa) lub jednoosobowy w gminie (wójt, burmistrz, prezydent miasta). Organ wykonawczy w samorządzie realizuje zadania publiczne za pomocą administracji publicznej i jednostek organizacyjnych. Z mocy prawa wszystkie jednostki samorządu terytorialnego zostały wyposażone w osobowość prawną i zasoby gospodarcze w celu wykonywania zadań publicznych. Zasoby obejmują: czynnik ludzki (kadry polityczne, administracyjne i gospodarcze), finanse oraz majątek (mienie) komunalny. Wielkość tych zasobów jest duża zarówno w sensie rzeczowym, jak i wartościowym ${ }^{3}$. Sytuacja ta określa prawne i ekonomiczne warunki podjęcia oraz prowadzenia działalności gospodarczej na rzecz społeczności lokalnej, a jednocześnie zobowiązuje do poszukiwania i doboru skutecznych narzędzi oraz rozwiązań dla efektywnego wykorzystania różnych składników zasobowych.

Samorząd terytorialny może być traktowany jako system gospodarowania dla wytworzenia strumienia dóbr publicznych w postaci produktów i usług. Istotą tego systemu jest mechanizm transformacji czynników (kapitałów) w procesie produkcyjno-usługowym. Wymóg racjonalnego gospodarowania tymi zasobami nakazuje ich wykorzystanie ze szczególną dbałością ekonomiczną

3 E. Wojciechowski, Zarządzanie w samorządzie terytorialnym, wydanie drugie poprawione i rozszerzone, Wydawnictwo Difin, Warszawa 2012, ss.55-56. 
dla wykonywania zadań własnych i zadań zleconych. Należy podkreślić, że główna uwaga w tej działalności powinna być zwrócona na wykonywanie kluczowego segmentu zadań własnych - o charakterze obligatoryjnym i użyteczności publicznej. Pozostałe zadanie własne mogą być realizowane w miarę istniejących potrzeb społecznych i posiadanych możliwości finansowych. Niezrozumiałe jest wprowadzanie w życie nowych rozwiązań (nazywanych często innowacyjnymi) absorbujących wysokie nakłady finansowe, kosztem jakości świadczenia usług w ramach obowiązkowych zadań własnych ${ }^{4}$.

W systemie gospodarowania samorządu istotne jest uwzględnienie podstawowych elementów układających się w określoną sekwencję działań. Są nimi przede wszystkim:

- identyfikacja potrzeb komunalnych i ich struktury (w zakresie usług publicznych), zgłaszanych przez mieszkańców i podmioty gospodarcze oraz wynikających ze stanu technicznego majątku samorządu,

- wyznaczenie głównych kierunków działania i określenie związanych z tym celów, w kontekście przyjętych horyzontów czasowych ich realizacji,

- określenie priorytetów rozwojowych w polityce gospodarczej samorządu,

- analiza nakładów finansowych, wynikających z potrzeb w powiązaniu z własnymi możliwościami budżetowymi,

- w przypadku niedoboru finansowego na realizację zadań, poszukiwanie alternatywnych rozwiązań pozyskania zasobów finansowych, łączących różne źródła kapitału (krajowego i zagranicznego).

Z kolei, samorząd ujmowany jako system zarządzania obejmuje działanie polegające na formułowaniu celów i zadań publicznych oraz harmonijnym doborze instrumentarium $\mathrm{w}$ formie środków i metod ich osiągania oraz realizacji. Proces zarządzania odnosi się do strukturalnego traktowania całokształtu działań polegających na wykonywaniu zadań własnych samorządu. Zarządzanie w samorządzie terytorialnym bardzo przypomina sposoby postępowania, występujące w kierowaniu przedsiębiorstwem prywatnym. Podmiotem zarządzania samorządowego są (tak jak wcześniej wspomniano) jego władze oraz związana z nim ściśle i podległa - administracja publiczna. W celu osiągania wyznaczonych celów i zadań, podmioty te korzystają z podobnego instrumentarium. Trudno nie zauważyć, że rozstrzygającym kryterium oceny w gospodarowaniu jest jego efektywność ekonomiczna, natomiast w zarządzaniu jest nim zapewnienie skuteczności osiągania założonych (planowanych) celów. Procesy gospodarowania i procesy zarządzania są ściśle ze sobą związane, stanowiąc wyraz dwóch aspektów tej samej działalności. W przypadku procesów zarządzania należy podkreślić, że ich treścią jest zarządzanie publiczne, które ze względu na charakter przynosi efekty społeczne i ekonomiczne dla członków wspólnoty.

4 Np. zagospodarowanie przestrzeni publicznej poprzez instalowanie tymczasowych urządzeń (tzw. strefa relaksu, parkiet). 
Istotną cechą ustroju samorządu, mającą duży wpływ na procesy gospodarowania i zarządzania jest element pozaekonomiczny, którym jest czynnik polityczny ${ }^{5}$. W samorządzie zbiorczo tworzy go organ stanowiący i organ wykonawczy. Są oni głównymi mechanizmami sprawczymi, kształtującymi warunki, zasady, cele i procedury postępowania w procesie świadczenia usług publicznych. Nadto, cele formułowane w samorządzie mają charakter polityczny i społeczny, ponieważ wynikają z badania potrzeb obywateli samorządu, którzy delegują do tego swoich przedstawicieli przez demokratyczny proces wyborczy. Z perspektywy analizy instytucjonalnej, samorząd stanowi organizację publiczno-gospodarczą funkcjonującą według określonych reguł gry. W teorii ekonomii zwraca się uwagę na istnienie związku między jakością instytucji a wzrostem gospodarczym.

Najistotniejszym czynnikiem kształtującym jakość instytucji są kwalifikacje i kompetencje zatrudnionych tam osób. Warto zauważyć, że do instytucji publicznych łatwo przenikają osoby legitymujące się słabym przygotowaniem zawodowym, jak też często wątpliwą postawą etyczną, w czym pomaga proporcjonalna ordynacja wyborcza. Od osób zajmujących wysokie stanowiska kierownicze zależy jakość działania całej instytucji. Jeżeli kierownik instytucji nie dysponuje zdolnościami do sprawnego kierowania, to w krótkim czasie doprowadzi do dysfunkcji i niewydolności całej organizacji. Tak jest również w całym sektorze publicznym, a w samorządzie jakość jego organu wykonawczego wpływa bezpośrednio na jakość zatrudnionych w urzędzie i w jednostkach organizacyjnych. Należy dodać, że zmiany zachodzące w bliższym i w dalszym otoczeniu, wywierają wpływ na gospodarkę samorządu. Tendencje światowe, priorytety UE wraz ze zmianą struktury potrzeb publicznych, procesami demograficznymi i społeczno-kulturowymi, wymagają nowych sposobów rozwiązywania problemów, stanowiących doniosłe wyzwania dla organów samorządu. Sama realizacja zadań publicznych wraz z kształtowaniem warunków rozwojowych, to za mało dla nowoczesnego samorządu, który musi brać udział w wypracowaniu nowych koncepcyjnie, metod i technik gospodarowania oraz zarządzania publicznego. Na tym bowiem polega kreatywność i innowacyjność funkcjonowania w złożonym i dynamicznym otoczeniu rynkowym. Wymaga to elastycznego podejścia, współpracy różnych podmiotów, zapewniających wyższą efektywność instytucjonalną na różnych szczeblach zarządzania (multi-level governance).

System gospodarowania i system zarządzania jako komplementarne komponenty struktury samorządu, zespalają się i przenikają. Z poznawczego punktu widzenia systemy te wyrażają dwa aspekty funkcjonowania samorządu: strukturalny (gospodarowanie) i funkcjonalny (zarządzanie). W gruncie rzeczy, gospodarowanie i zarządzanie stanowią dwie strony tego samego medalu, którym jest proces

$5 \mathrm{Z}$ istoty, samorząd terytorialny ma charakter polityczny, ze względu na trzy okoliczności. Po pierwsze, stanowi polityczną organizację społeczeństwa lokalnego; po drugie, jego organami jest władza publiczna wyłaniana bezpośrednio lub pośrednio w wyborach przez mieszkańców według zróżnicowanej ordynacji wyborczej; po trzecie, gospodarowanie i zarządzanie ma charakter publiczny, w których wielu uczestników posiada rodowód partyjny. 
świadczenia usług publicznych i proces kształtowania warunków dla zrównoważonego rozwoju samorządu.

Od kilku lat dyskutuje się i postuluje na temat zmiany paradygmatu w obszarze odejścia od tradycyjnego zarządzania w sektorze samorządowym na rzecz coraz szerszego wykorzystywania rozwiązań rynkowych (koncepcja new public management). Źródłem inspiracji nowych technik i metod zarządzania jest sektor prywatny. Zmiana orientacji, polegająca m.in. na przejściu od nastawienia na nakłady w kierunku podejścia wynikowego, miała służyć poprawie jakości i w dostępności do oferowanych usług publicznych oraz zwiększeniu ich efektywności. Takie działania powinny być nakierowane na wcześniejsze określenie standardów i mierników poszczególnych zadań publicznych, a następnie na kontrolę wyników działalności, czyli mierzenia konkretnych dokonań z uwzględnieniem celów i rezultatów. Krytyka modelu rynkowego funkcjonowania władzy i administracji w wielu krajach legła u podstaw nowej koncepcji określanej mianem public governance. Elementami tego modelu są: koordynacja w strukturach sieciowych, partnerstwo w wypracowaniu decyzji, współdziałanie oraz stosowanie procedur konsultacyjnych, mediacyjnych i negocjacyjnych. W ostatnim czasie, na podstawie zebranych doświadczeń, pojawiła się hybrydowa koncepcja neoweberyzmu, nawiązująca do modelu administracyjnego, rynkowego i sieciowego (partycypacyjnego), która chyba najlepiej (elastycznie) pozwala korzystać z bogatego instrumentarium zarządzania publicznego zgromadzonego $\mathrm{w}$ trzech poprzednich systemach funkcjonowania gospodarki publicznej ${ }^{6}$.

W działalności samorządu większość wyznaczonych celów ma niestety charakter niemierzalny (nie można ich bezpośrednio zmierzyć, tak jak nakłady rzeczowe czy finansowe). Pomiar efektów działalności jednostki samorządowej występuje w wielu dokumentach administracyjnych, mających wpływ na funkcjonowanie i rozwój danej jednostki. Dobrym przykładem może być strategia rozwoju społeczno-gospodarczego lub polityka sektorowa, różne programy i projekty gospodarcze. Do najbardziej popularnych mierników rezultatu, stosowanych w jednostkach samorządu terytorialnego w zakresie rozwoju infrastruktury technicznej, można przykładowo zaliczyć:

- osoby korzystające ze zbiorowego transportu miejskiego,

- ludność przyłączoną do gminnej sieci wodociągowej,

- ludność przyłączoną do sieci kanalizacyjnej,

- ludność przyłączoną do sieci ciepłowniczej.

6 Pierwszą próbą w zapewnieniu wyższej efektywności sektora publicznego była koncepcja New Public Management (NPM) pozostająca w opozycji do tradycyjnego modelu administracji publicznej w ujęciu M. Webera. Celem NPM była wyższa sprawność ekonomiczna działania władz i administracji publicznej. Praktyka pokazała, że nie wszędzie i nie wszystkie rozwiązania tej koncepcji znalazły zastosowanie w sektorze publicznym. Kolejna koncepcja public governance rozwija niejako wątki NPM. 
Mierniki te obrazują zakres dostępności mieszkańców wspólnoty samorządowej do podstawowych usług publicznych. W zakresie rozwoju e-usług podstawą jest dostęp do Internetu przez mieszkańców.

Wyniki działalności trzeba definiować i porównywać z najlepszymi (benchmarking). Warto przypomnieć, że mierzenie rezultatów zapisane jest w budżecie zadaniowym. Instrument ten stanowi, że zarządzanie środkami publicznymi odbywa się przez pryzmat planowanych i osiągniętych efektów poszczególnych zadań. Służy temu system mierników, obrazujących powiązanie kosztów zadań publicznych z ich zakresem rzeczowym. W tym przypadku mieszkańcy uzyskują, istotną $\mathrm{z}$ ich punktu widzenia, informację $\mathrm{w}$ zakresie kosztu poszczególnych usług komunalnych, za co dokładnie płacą i uzyskanych efektów. Ponadto, rozbudowany system wskaźników umożliwia dokonanie analizy porównawczej, w celu przeprowadzenia obliczeń kosztów wykonywania zadań publicznych przez różne jednostki samorządowe. Zgromadzony w ten sposób materiał faktograficzny pozwoli na formułowanie ocen wyższej lub niższej efektywności ekonomicznej struktur organizacyjnych samorządu.

Zagadnieniem, które wpływa na efektywność gospodarki finansowej w samorządzie są jego relacje z centralną administracją publiczną. We współczesnym państwie i w gospodarce rynkowej, samorząd stanowi ustrojowy element państwa i funkcjonuje w otoczeniu rynkowym. Samorząd jako odbicie decentralizacji funkcji państwa realizuje jednocześnie zadania publiczne $w$ formule administracji zdecentralizowanej. W ślad za tym powinna następować decentralizacja finansów publicznych. Według badania M. Poniatowicz, w Polsce występuje średni poziom decentralizacji finansów $(0,30)^{7}$. Najwyższe poziomy osiągają państwa o ustroju federacyjnym (Kanada, Szwajcaria, Niemcy, USA). Autorka przeprowadziła ciekawą i pogłębioną analizę poziomu decentralizacji w wybranych państwach OECD. W tym celu opracowano metodę badawczą pozwalającą na obliczenie miernika syntetycznego MPDF (miernik poziomu decentralizacji fiskalnej). Miernik powstał na podstawie ośmiu cech diagnostycznych, z których tylko jedna miała cechy destymulanty. Po normalizacji cech oraz obliczonej odległości od wzorca i anty wzorca uzyskano wartość wskaźnika syntetycznego, przy średniej wynoszącej 0,37 , odchyleniu standardowym 0,15 i współczynniku zmienności 39,4\%. Znamiennym rysem badań jest kształtowanie się najwyższych wartości wskaźnika w państwach federacyjnych niż w unitarnych. Wartości tego miernika przedstawia tabela 1.

7 M. Poniatowicz, Koncepcja federalizmu fiskalnego w systemie finansów samorzq̨du terytorialnego, Wydawnictwo CeDeWu, Warszawa 2018, s. 267-268. 
Tabela 1. Wybrane państwa OECD wg poziomu decentralizacji (podsektor subnational government; 2015)

\begin{tabular}{|l|l|l|l|}
\hline $\begin{array}{c}\text { Grupa } \\
\text { państw }\end{array}$ & $\begin{array}{c}\text { Poziom } \\
\text { decentralizacji }\end{array}$ & $\begin{array}{c}\text { Zakres wartości } \\
\text { wskaźnika MPDF }\end{array}$ & \multicolumn{1}{|c|}{ Państwa } \\
\hline I grupa & bardzo wysoki & 0,52 i powyżej & $\begin{array}{l}\text { Kanada, Szwajcaria, Niemcy, Stany } \\
\text { Zjednoczone }\end{array}$ \\
\hline II grupa & wysoki & $0,37-0,52$ & $\begin{array}{l}\text { Hiszpania, Japonia, Szwecja, Belgia, } \\
\text { Finlandia, Francja, Australia, Czechy, Dania, } \\
\text { Islandia, Norwegia }\end{array}$ \\
\hline III grupa & średni i niski & $0,22-0,37$ & $\begin{array}{l}\text { Korea, Włochy, Łotwa, Izrael, Stowacja, } \\
\text { Polska, Węgry, Stowenia, Holandia, } \\
\text { Portugalia, Estonia }\end{array}$ \\
\hline IV grupa & bardzo niski & poniżej 0,22 & $\begin{array}{l}\text { Luksemburg, Wielka Brytania, Irlandia, Turcja, } \\
\text { Grecja }\end{array}$ \\
\hline
\end{tabular}

Źródło: M. Poniatowicz, Koncepcja federalizmu fiskalnego w systemie finansów samorzq̨u terytorialnego, Warszawa 2018, s. 270.

Samorząd nie może być traktowany jako system i władza publiczna przeciwstawna państwu i władzy centralnej. W doktrynie prawnej i w literaturze ekonomicznej kluczowe miejsce zajęła teoria państwowa samorządu terytorialnego, traktująca samorząd jako integralny element struktury państwa demokratycznego. Odmiennie do modelu samorządu, w teorii prawa naturalnego (przeciwstawność interesów gminy i państwa) samorząd realizuje cele i interesy, które nie mogą być sprzeczne z celami i interesami państwa jako całości. Wobec tego układ samorządu jest komplementarny wobec układu centralnego w systemie państwa i gospodarki.

Rozwiązania ustrojowe dotyczące samorządu terytorialnego oraz prowadzona polityka makroekonomiczna rządu, z założenia mają tworzyć warunki zapewniające zbieżność interesów samorządu i interesów państwa jako całości. Z punktu widzenia systemowego, samorząd terytorialny tworzy segment regionalny i lokalny w gospodarce, natomiast władze i administracja rządowa - segment centralny. Ostatni segment obejmuje zarówno naczelne, w zakresie regulacji prawnej (ustawy), jak i centralne władze publiczne oraz ich administracje. Prawie we wszystkich krajach na świecie zachodzi „subtelna gra” interesów prowadzonych na wymienionych poziomach zarządzania publicznego. W pewnym stopniu gra ta przybiera postać swoistej walki, rywalizacji w sprawowaniu władzy publicznej (jak np. w Wielkiej Brytanii, w Polsce). 



\section{Rozdział III}

\section{Specyfika gospodarki samorządu Implikacje ekonomiczne}

Gospodarowanie środkami finansowymi i trwałymi w jednostkach samorządowych podlega różnego rodzaju ograniczeniom, nakładającym na władzę i administrację samorządową określone procedury, standardy i reżimy, głównie wynikające z przepisów prawa ${ }^{1}$. Kategorie te mają znaczenie ekonomiczne, ponieważ ich zastosowanie $\mathrm{w}$ praktyce samorządowej wymaga poniesienia odpowiedniego kosztu. Jest on zróżnicowany w zależności od wielkości jednostki samorządowej, jej statusu prawno-administracyjnego oraz czynnika tradycji, kultury, zwyczajów. Otoczeniem dla procesu realizacji zadań własnych samorządu jest gospodarka rynkowa. Należy zauważyć, że również sam samorząd tworzy układy konkurencyjne $\mathrm{w}$ procesie wykonywania zadań, zarówno w działalności bieżącej, jak i inwestycyjnej. Nie wszystkie jednak mechanizmy rynkowe i metody zarządzania w sektorze prywatnym mają efektywne zastosowanie w systemie samorządu. Można to tłumaczyć cechami gospodarki samorządowej, które charakteryzują wyraźnie jej odrębność w świetle obszaru gospodarki rynkowej. Specyfika ta stanowi wyłom od logiki rynkowej i jest organicznie związana z warunkami działalności gospodarczej samorządu. By przejść do opisu podstawowych odrębności konieczne jest przypomnienie o mechanizmach oddziaływania samorządu na gospodarkę i podejmowanych w niej decyzjach.

Tworzenie i funkcjonowanie struktur samorządu odbywa się w dwóch typach oddziaływania na prowadzenie działalności gospodarczej:

- regulacji rynkowej,

- regulacji administracyjnej.

1 Przez procedurę działania należy rozumieć sformalizowany tok postępowania, określony w etapach czasowych. Standard - oznacza przyjęcie określonej normy lub zbioru właściwości, wzorca, którymi należy kierować się w racjonalnej działalności publicznej. Działanie - według reżimu oznacza dostosowanie się do narzuconych zasad i ograniczeń. Wiąże się to z ponoszeniem pewnych wyrzeczeń, dużej dyscypliny, w imię osiągnięcia wyższej efektywności ekonomicznej. O ile procedury porządkują i standaryzują działalność, to stosowanie reżimu jest szczególnie istotne w działalności bieżącej, w której tkwią rezerwy w wykorzystaniu zasobów gospodarczych. 
W założeniu, oddziaływanie mechanizmu rynkowego ma tworzyć presję na producentów dóbr (strona podaży) oraz ich nabywców i konsumentów (strona popytu) w celu podjęcia decyzji, zgodnych z kryteriami racjonalności ekonomicznej i społecznej. Władze samorządowe tworzą instytucjonalne podstawy dla sprawnego działania rynku, zapewniającego warunki konkurencji w obszarze produkcji (podaży) i zapotrzebowania w zakresie produktów i usług publicznych. Nieskrępowany mechanizm rynkowy ma doprowadzić do efektywnej alokacji ograniczonych zasobów gospodarczych pomiędzy konkurencyjne cele (dziedziny gospodarowania). W świetle teorii ekonomii, bezpośrednia konkurencja przy swobodzie wyboru konsumentów przyczynia się m.in. do obniżania cen dóbr, poprawie ich jakości, niższych kosztów wytwarzania, większej podaży - w sensie lepszej dostępności przestrzennej do podstawowych usług komunalnych. W praktyce wpływ mechanizmu rynkowego na gospodarkę samorządu wykazuje wiele ułomności, powodujących jego niesprawności (market failures)2.

Niedoskonałość rynku jest traktowana jako uzasadnienie do ingerencji czynnika administracyjnego w gospodarkę samorządu. Interwencja w procesy i w zjawiska gospodarki samorządowej ma służyć obronie interesu społecznego mieszkańców wspólnoty przed wadliwie funkcjonującym rynkiem. Także obszar oddziaływania władz i administracji samorządowej w sferze gospodarki, charakteryzuje się licznymi słabościami, określanymi w literaturze ekonomicznej jako government failures ${ }^{3}$. Z koncepcyjnego punktu widzenia, mechanizm regulacji rynkowej może wykazać swoje walory tylko w jednym przypadku, gdy na kierowniczych stanowiskach wyższego szczebla będą zatrudnione osoby posiadające wysokie kwalifikacje zawodowe i kierujące się wartościami etycznymi. W każdej sytuacji, czynnik administracyjno-publiczny powinien dokonać kalkulacji, czy koszty ingerencji nie są wyższe od przewidzianych efektów? Za istotne odrębności gospodarowania zasobami w sferze samorządu należy uznać:

- odmienny od logiki biznesu, cel działalności,

- monopolistyczny charakter wielu dziedzin funkcjonowania,

- proces zarządzania (warunki podejmowania decyzji, formalizm, czas, partycypacja społeczna),

- rozproszoną i „rozmytą” odpowiedzialność oraz rozliczalność,

- odrębny reżim i rygory prawne, regulujące procesy gospodarowania zasobami,

- sprawczy wpływ czynnika pozaekonomicznego (politycznego),

- publiczny charakter działalności organów samorządu i jednostek organizacyjnych (jawność).

Istotne znaczenie dla przebiegu procesów decyzyjnych w samorządzie mają podstawy prawne, które wpływają na: sprawność działań gospodarczych i administracyjnych, koszt działalności i elastyczność postępowania. Jak wcześniej

2 Joseph E. Stiglitz, Ekonomia sektora publicznego, Wydawnictwo Naukowe PWN, Warszawa 2004, s. 91-102.

3 Ibidem, s. $10-12$. 
stwierdzono, treść i ramy funkcjonowania oraz rozwoju gospodarki samorządu wyznaczają wartości, standardy i procedury administracyjne $e^{4}$ Wartości są integralnie związane z procesem formułowania celów i zadań publicznych. Standardy traktowane jako swoiste normy postępowania, działań, wytwarzania mają w samorządzie dwoisty charakter. Część z nich jest określona wprost przez krajowe regulacje prawne (np. parametry jakości wody, ścieków), inne natomiast kształtowane są dowolnie przez władze samorządu, na miarę potrzeb i możliwości finansowych (np. usługi transportu zbiorowego, usługi rekreacyjno-wypoczynkowe).

Szczególnej uwagi wymagają procedury administracyjne, określające schemat postępowania w świadczeniu usług publicznych. W samorządzie występuje wielość procedur, które z kolei składają się na procesy zachodzące w poszczególnych ogniwach i branżach gospodarki samorządu. Następną cechą tych procedur jest ich wysoka złożoność, ze względu na rozbudowaną i skomplikowaną strukturę administracji publicznej. Prowadzi to do niskiej przejrzystości w sekwencji zachowań, jeśli odbywa się równocześnie z funkcjonowaniem dużej liczby jednostek organizacyjnych samorządu (uczestników procesów usługowych w gospodarce). W sferze biznesu występują również mocno sformalizowane procedury działania, które w zderzeniu z relatywnie mniejszą liczbą kontrahentów (uczestników), zapewniają wyższą transparentność, a zatem odpowiedzialność.

W odróżnieniu od sektora prywatnego, gospodarka finansowa samorządu jest jawna. Podmioty prywatne zasłaniając się tajemnicą handlową (do czego mają prawo), pilnie strzegą informacji o warunkach i czynnikach wpływających na podejmowane decyzje gospodarcze. W samorządzie, jego publiczny charakter, nakazuje udostępnienie mieszkańcom wspólnoty, wielu informacji o procesie gospodarowania. Ilustracją tego jest prawne zagwarantowanie jawności prowadzenia gospodarki finansowej przez władze samorządu. Według M. Jastrzębskiej, jawność oznacza swobodny dostęp mieszkańców i instytucji do danych finansowych jednostki samorządu ${ }^{5}$. Jawność działania w samorządzie pogłębiona jest przez coraz silniej zaznaczający się proces partycypacji obywatelskiej w podejmowaniu decyzji. Łatwo zauważyć, że w małych samorządach ma miejsce wyższe zaangażowanie mieszkańców w zarządzaniu, a zachodzące tam procesy są bardziej przejrzyste ze względu na rozmiar i strukturę gospodarki lokalnej. W istocie, w niewielkich samorządach, partycypacja obywatelska nie odgrywa tak dużej roli, jak w średnich i w dużych jednostkach terytorialnych, $\mathrm{z}$ uwagi na bezpośredni i częsty kontakt zainteresowanych mieszkańców ze swoimi przedstawicielami.

Przedsiębiorstwa prywatne w swojej działalności skupiają się na kwestiach ekonomicznych, owocujących osiąganiem określonego poziomu zysku. W strukturze swojego działania podmioty te pozbawione są komponentu politycznego, który

4 E. Wojciechowski, Ekonomiczne oblicze samorzq̨du terytorialnego, [w:] Finanse i ryzyko w ksztattowaniu rozwoju regionu, (red.) M. Dylewski, Zeszyty Naukowe Wyższej Szkoły Bankowej w Poznaniu, nr 41, Poznań 2012, s. 205-206.

5 M. Jastrzębska, Jawność i przejrzystość sprawozdawczości jednostek samorzadu terytorialnego - ocena i rekomendacje, „Nierówności Społeczne a Wzrost Gospodarczy” 2018, nr 56, s. 64. 
może zakłócać racjonalne postępowanie na rynku konkurencyjnym. W samorządzie występuje inna sytuacja. Organy samorządu, delegowane przez mieszkańców w procesie wyborczym, mają charakter polityczny. Występuje tutaj dualizm roli i funkcji tych władz, gdyż z jednej strony uzyskują bezpośrednią i pośrednią ( $w$ mniejszym zakresie $\mathrm{w}$ powiecie i w województwie) legitymizację demokratyczną, z drugiej natomiast większość organów posiada rodowód partyjny. W tym ostatnim przypadku może zachodzić sprzeczność interesów i celów popierającej partii politycznej, z interesami oraz celami gospodarki wspólnoty samorządowej, o które ma dbać i osiągać organ wykonawczy.

Gospodarka finansowa jednostek samorządu funkcjonuje i rozwija się pod wpływem zasad, prawnych rygorów, standardów i procedur postępowania. Czynniki te wprowadzają formalizm i sztywność w przebiegu procesów i zjawisk finansowych. Można powiedzieć, że gospodarka finansowa samorządów odznacza się dużo niższą swobodą działania niż gospodarka rynkowa, oparta na wolności gospodarczej i mechanizmie nieskrępowanej konkurencji. Działanie w gospodarce finansowej pod wpływem regulacji pozaekonomicznych i politycznych powoduje, że odbywa się ono w obrębie pewnego reżimu finansowego oraz charakteru użyteczności publicznej znakomitej części zadań publicznych.

W gospodarce finansowej samorządu występuje naturalna sekwencja działań układających się w logiczny ciąg (proces) postępowań i związanych z tym decyzji, począwszy od świadomości regulacji prawnych aż do określenia sposobu finansowania wykonania zadań publicznych oraz przedsięwzięć gospodarczych z tym związanych. W praktyce ciąg tych działań tworzy tzw. zamknięty cykl („koło” zdarzeń), którego treścią jest kształtowanie pożądanych procesów i zjawisk gospodarki finansowej samorządu. Zarysowany układ tworzą następujące zespoły działań:

- podstawy prawne,

- specyfikacja priorytetów rozwojowych i celów publicznych (zarys kierunku),

- gromadzenie informacji o obszarze zadań publicznych i możliwościach pozyskania źródeł ich finansowania,

- partycypacja społeczna w zakresie celów i zadań rozwojowych (konsultacje, debaty, negocjacje),

- planowanie finansowe (instrumenty, zasady, procedury),

- analiza i ocena kształtowania dochodów własnych,

- kluczowe rozstrzygnięcia polityki finansowej samorządu (działalność bieżąca i inwestycyjna),

- budżet obywatelski (obligatoryjność i dowolność),

- rozważenie możliwości finansowania hybrydowego (partnerskiego),

- konstruowanie mechanizmu montażu finansowego (problematyka deficytu i długu),

- realizacja budżetu,

- monitorowanie i nadzór nad przebiegiem wykonywania budżetu,

- sprawozdawczość budżetowa (odcinkowa i całościowa), 
- ocena finansowania i wykonania zadań publicznych (roczne sprawozdanie z wykonania budżetu, sprawozdanie finansowe, raport - wotum zaufania, absolutorium dla organu wykonawczego).

Punktem wyjścia są wspomniane przepisy prawne, które są nadrzędne wobec następnych etapów działań. Cechą charakterystyczną dla decydenta finansowego jest ogrom przepisów prawnych i ich duża zmienność (częste nowelizacje). W szystko to utrudnia wydatnie postępowanie w planowaniu i realizacji gospodarki finansowej samorządu. Nadto, sytuacja ta powoduje powstawanie wielu nieprawidłowości (błędy, uchybienia, naruszenia, nieracjonalność, zaniechanie, niepełne wykorzystanie możliwości $\mathrm{z}$ uwagi na brak informacji lub brak znajomości procedury w tym zakresie). Nadmiar regulacji prawnych oraz ich liczne zmiany, jak też częsta niespójność $\mathrm{w}$ przepisach, wprowadzają $\mathrm{w}$ ich początkowym okresie chaos, dezorientację oraz pewną bezradność we wdrożeniu decyzji finansowych w życie.

Sprawność gospodarki samorządu zależy zatem od warunków i funkcjonowania oraz jakości zarządzania przez organ wykonawczy. Niejako zbiorczą implikacją ekonomiczną $\mathrm{w}$ przedstawionej powyżej specyfice samorządu jest kształtowanie się różnych poziomów efektywności gospodarowania. W teorii samorządu, to kluczowe kryterium oceny w analizie ekonomicznej jest traktowane jako instrument racjonalizujący dokonywane wybory, w przekonaniu, że efektywność gospodarowania zasobami w jednostkach samorządu jest wyższa od efektywności decyzji podejmowanych na poziomie centralnym. Abstrahując w tym miejscu od specyfiki samorządu, można sformułować wniosek, że dominujący wpływ na efektywność ekonomiczną w różnych strukturach samorządu ma czynnik polityczny, a konkretnie organ wykonawczy. Od niego bowiem zależy wybór sposobów wykonywania zadań (choć niektóre z nich są narzucone centralnie), czy wybór metod i narzędzi realizacji polityki samorządowej, z umiejętnością uwzględnienia zarysowanych odrębności. 



\section{Rozdział IV}

\section{Zarządzanie finansami a proces decyzyjny}

Gospodarowanie zasobami finansowymi w samorządzie odbywa się w ramach systemu ekonomicznego oraz polityki finansowej. System ekonomiczny kształtowany jest przepisami prawa i obejmuje strukturę działania, która motywuje do podejmowania racjonalnych decyzji. System finansowy stanowi część systemu ekonomicznego, odzwierciedlający procesy i zjawiska związane z gromadzeniem środków finansowych oraz ich rozdysponowaniem. Odbywa się to według ustalonych procedur postępowania, określanych przez system decyzyjny, który zawiera w sobie proces pozyskiwania informacji, ich oceny, podjęcia decyzji, a następnie przekazanie ich do wykonania. Można powiedzieć, że system decyzyjny stanowi sformalizowany tok podejmowania działań na poszczególnych etapach gospodarki finansowej, regulujący przepływ środków finansowych pomiędzy różnymi ośrodkami decyzyjnymi. System decyzyjny przenika się z systemem zarządzania finansami sprawiając, że występuje w nim pewna specyfika wobec klasycznego procesu decyzyjnego.

Cechą charakterystyczną w samorządzie (tak jak w całym sektorze publicznym) jest złożoność, wieloszczeblowość i względnie długi horyzont czasowy podejmowania decyzji. Specyfika ta wpływa na ponoszenie większego kosztu funkcjonowania i rozwoju jednostki samorządowej. Odrębność procesu decyzyjnego w sektorze publicznym (samorządu) jest zgodna z koniecznością zapewnienia bezpieczeństwa finansowego $\mathrm{w}$ jego gospodarowaniu. System decyzyjny w gospodarce finansowej nie jest odseparowany od podejmowania decyzji w innych dziedzinach gospodarki i życia społecznego. Należy zaznaczyć, że dominująca część decyzji ekonomicznych, niejako z istoty, wywołuje skutki finansowe. System ekonomiczny (finansowy i zarządzania) stwarza możliwości wykonywania zadań, zaś polityka gospodarcza (finansowa) ma charakter realizacyjny, który może w praktyce odbiegać od systemu ekonomicznego. Odrębną rzeczą jest „zawartość” systemu - czyli mechanizm funkcjonowania - który ma zachęcać do podejmowania racjonalnych decyzji finansowych. 
Zarządzanie środkami finansowymi jest aktywne i polega na tworzeniu warunków dla pozyskiwania dochodów oraz ich podziale i wydatkowaniu dla osiągania różnych konkurencyjnych celów (zadań publicznych). Proces zarządzania tymi środkami tworzy zbiór działań podmiotów organizacyjnych, składających się na system. W powiązanych ze sobą elementach zachodzą procesy realizujące podstawowe funkcje zarządzania: organizowanie, planowanie, motywowanie, koordynowanie i kontrola. Organizowanie systemu zarządzania finansami dotyczy specyfikacji podmiotów biorących udział w przepływie środków finansowych systemu. Ważną rzeczą jest jednocześnie określenie zakresu zadań dla podmiotów oraz ustalenie ich hierarchii. Planowanie w zorganizowanym już systemie dotyczy opracowania dokumentów niezbędnych dla prowadzenia gospodarki finansowej samorządu w krótkim i w długim okresie czasowym.

Jak wcześniej zaznaczono, szczególne miejsce w gospodarce publicznej zajmuje gospodarowanie środkami finansowymi. Jest to obszar, w którym (jak w soczewce) kumulują się pozytywne i negatywne zjawiska życia publicznego, polityki oraz biznesu. Nie są od nich wolne i samorządy terytorialne, gdyż stanowią integralny element systemu państwowego i gospodarki. Także tu widać efekty błędnych decyzji, rozrzutności, niegospodarności, inwestycje pozbawione perspektywy czasowej. Samorząd jest również obszarem działań nieracjonalnych. Najwyższa Izba Kontroli dopiero od 1994 r. objęła kontrolą gospodarkę jednostek samorządowych, a kolejne raporty ujawniały nieprawidłowości i naganne praktyki władz oraz administracji ${ }^{1}$. Bez wątpienia w każdej dziedzinie i działalności (szczególnie bieżącej) występują pewne rezerwy środków, a ich wielkość jest jedynie funkcją skali wydatków². Według B. Guziejewskiej, lepsze zarządzanie finansami występuje w ramach samorządu i służy poprawie efektywności. W przypadku konieczności współpracy z innymi podmiotami, efektywność spada ${ }^{3}$. Można domniemywać, iż chodzi tutaj o rozmycie odpowiedzialności i koszty partnerstwa związanego m.in. z koordynacją wspólnych działań. Warto zauważyć, że efektywność zależy też od jakości zarządzania i stopnia przejrzystości, jak też może wiązać się z wielkością jednostki samorządowej (ekonomia skali). Lepsza jakość zarządzania wpływa na wyższy poziom efektywności i przejrzystości. Można zauważyć, że efektywność będzie zapewne wyższa w małych samorządach (transparentność, kontrola, liczba realizowanych projektów), a niższa w dużych samorządach (rozbudowane struktury

1 Por. m.in. Najwyższa Izba Kontroli, Funkcjonowanie spótek komunalnych w województwie tódzkim. Informacja o wynikach kontroli, Warszawa 2014; Najwyższa Izba Kontroli, Przegląd kontroli przeprowadzonych w jednostkach samorządu terytorialnego przez Najwyższą Izbę kontroli w latach 2011-2013. Ważniejsze nieprawidłowości i dobre praktyki, Warszawa 2014.

2 Nieetyczne jest, aby prezes spółki komunalnej zarabiał więcej niż prezydent dużego miasta. Przykładowo, wynagrodzenie prezesa spółki miejskiej jest ponad dwukrotnie wyższe niż prezydenta miasta (Łódź). Należy jednak zwrócić uwagę na relatywnie niskie wynagrodzenia prezydentów dużych miast w stosunku do wynagrodzeń organu wykonawczego w pozostałych gminach. Kwestia ta powinna znaleźć rozwiązanie w stosownej regulacji prawnej.

3 B. Guziejewska, Finanse publiczne wobec wyzwań globalizacji..., s. 164. 
organizacyjne, słaba przejrzystość, brak skutecznej kontroli społecznej, naciski wielu grup interesów). Z teoretycznego punktu widzenia, efektywność powinna być wyższa w dużych samorządach (korzyści skali, wspólne centra usług), za sprawą większej elastyczności działania, pod warunkiem zapewnienia wyższej jakości profesjonalnego zarządzania (wyeliminowaniu czynnika partyjnego).

Istotną dysfunkcją w gospodarce samorządu jest sposób sprawowania nadzoru właścicielskiego. W praktyce w zarządach wielu spółek komunalnych i w ich radach nadzorczych znajdują się osoby, którym stanowiska przypadły ze względów politycznych lub towarzyskich. Można to zaakceptować, pod jednym warunkiem, że są to osoby przygotowane do tego zawodowo. Brak lub słaby nadzór właścicielski obarcza bezpośrednio organy samorządowe, a szczególnie organ wykonawczy. Warto jeszcze raz przypomnieć, że środki publiczne są własnością ogółu mieszkańców wspólnoty samorządowej, a nie pojedynczych osób czy grup interesu. Racjonalne gospodarowanie zasobami finansowymi w samorządzie jest obowiązkiem władz (głównie organu wykonawczego) wybranych przez mieszkańców, a jednocześnie drogą realizacji interesu publicznego.

Trudna sytuacja w samorządzie wymaga podjęcia działań konsekwentnych i gruntownych. Jest to warunek poparcia społecznego i większego zaufania do władzy publicznej, od której oczekuje się, że będzie sprawna i skuteczna w rozwiązywaniu problemów oraz w kształtowaniu warunków wyższej jakości życia. Nade wszystko, konieczne jest zorganizowanie autentycznego wpływu mieszkańców na decyzje ich dotyczące, m.in. poprzez zmianę ordynacji wyborczej na większościowąa ${ }^{4}$ Schodząc do podstawowej jednostki samorządu (gminy), nie zawsze o jej rozwoju decyduje jedynie pozyskanie poważnego inwestora (inwestorów). Równie ważną rzeczą jest systematyczna praca, racjonalizująca i budująca podstawy organizacyjne, ekonomiczne oraz planistyczne dla uzyskania korzystnych efektów społecznych (pro publico bono). Jest to możliwe po przeprowadzeniu zmian ustrojowych w prawodawstwie dotyczącym samorządu terytorialnego w Polsce.

Warto też podkreślić, że racjonalne gospodarowanie środkami publicznymi nie zawsze musi ograniczać się do stosowania w zamówieniach publicznych na dostawy, roboty budowlane, czy usługi - kryterium najniższej ceny. W praktyce powinny być stosowane takie kryteria jak: jakość, funkcjonalność, parametry techniczne, zastosowanie najlepszych dostępnych technologii w zakresie oddziaływania na środowisko, serwis, termin wykonania robót, a w szczególności koszty eksploatacji składnika majątkowego po oddaniu go do użytkowania. O racjonalności w gospodarowaniu środkami budżetowymi świadczyć może stosowanie mechanizmów

4 Niezrozumiałe jest utrzymywanie w samorządzie dwóch różnych ordynacji wyborczych - szczególnie w gminach. Zdaniem autorki, ordynacja większościowa ma zdecydowanie więcej walorów niż ordynacja proporcjonalna, obowiązująca w gminach powyżej 20 tys. mieszkańców. Z obserwacji życia samorządowego wynika, że ordynacja proporcjonalna prowadzi do upartyjnienia samorządów gminnych, głównie w miastach wojewódzkich; por. E. Wojciechowski, Zarządzanie w samorządzie terytorialnym, wydanie drugie poprawione i rozszerzone, Wydawnictwo Difin, Warszawa 2012, s. 76-77. 
umożliwiających uzyskiwanie nowoczesnych i innowacyjnych rozwiązań. Rozsądne postępowanie w działalności samorządu (w procesach gospodarczych), polegające na poprawnym myśleniu oraz skutecznym działaniu powinno dać pożądane efekty. W teorii ekonomii, racjonalne gospodarowanie występuje w dwóch równoważnych wariantach: jako zasada maksymalnej wydajności (największego efektu) oraz jako zasada oszczędności środków (najmniejszego nakładu). Racjonalne gospodarowanie oznacza dążenie do tego, aby przy danym nakładzie środków uzyskać maksymalny stopień realizacji celu - lub przy danym stopniu realizacji celu użyć minimalnego nakładu środków - naturalnie bez obniżenia jakości efektu. Takie pojmowanie racjonalności gospodarowania jest zbyt wąskie i upraszcza jego rzeczywistą naturę. Oznacza bowiem utożsamianie racjonalności z efektywnością, czyli korzystną relacją odpowiednio zdefiniowanych nakładów i efektów. Tymczasem efektywność nie zawsze jest równoznaczna z racjonalnością. Instrumentami zarządzania finansami samorządu terytorialnego są:

- planowanie,

- rachunkowość budżetowa,

- sprawozdawczość budżetowa,

- analiza finansowa,

- kontrola i audyt.

Można powiedzieć, że planowanie i realizacja wydatków ze środków publicznych to jedno $\mathrm{z}$ największych wyzwań związanych z zarządzaniem publicznym. Podczas planowania należy wybrać najlepszą alokację środków publicznych, z uwzględnieniem zgłaszanych potrzeb społeczno-gospodarczych. Przy wyborze celów, które mają być realizowane i osiągnięte za pomocą środków budżetowych, należy uwzględnić możliwości strategicznego rozwoju jednostki samorządowej oraz uwarunkowania wewnętrzne i zewnętrzne w kontekście perspektywy wieloletniej. Zarządzanie finansami samorządowymi to złożony proces, który dotyczy podejmowania różnych wzajemnie powiązanych działań i decyzji, służących maksymalizacji ekonomicznych i społecznych efektów, zgodnie z przyjętymi celami bieżącymi oraz strategicznymi. Obejmuje on kształtowanie dochodów i przychodów oraz wyznaczanie alokacji środków, $\mathrm{z}$ uwzględnieniem potrzeb społeczności lokalnej, przy zachowaniu zasad racjonalnego gospodarowania. Zarządzanie finansami można podzielić na:

- bieżące (operacyjne), związane z bieżącym zarządzaniem działalności jednostki samorządowej w trakcie roku budżetowego,

- strategiczne (wieloletnie), związane z działalnością rozwojową, czyli realizacja inwestycji samorządowych i wykorzystanie zewnętrznych źródeł ich finansowania.

Budżet jako instrument zarządzania finansami samorządowymi spełnia następujące funkcje:

- pomaga określić przyszłe zapotrzebowanie na poszczególne usługi komunalne oraz odpowiednio ukierunkować politykę władz samorządowych na ich wykonanie (funkcja planistyczna), 
- pozwala na prawidłowe wykorzystanie środków finansowych posiadanych przez samorząd (funkcja optymalizacji i nadzorcza),

- umożliwia rozliczenie działalności władz samorządowych (funkcja kontrolna),

- łączy władze samorządowe ze społecznością lokalną, zwłaszcza w fazie planowania budżetu i jego realizacji (funkcja demokratyczna),

- jest instrumentem pomocnym przy realizacji polityki społeczno-gospodarczej jednostki samorządowej (funkcja promocji).

Najważniejszą cechą dobrze opracowanego i wykonanego budżetu jest minimalizowanie rozbieżności między tym, co zostało zaplanowane w budżecie, a tym co zostało osiągnięte. Jednym z kluczowych narzędzi umożliwiających doskonalenie sytemu zarządzania finansami publicznymi - w tym samorządowymi - jest budżet zadaniowy. Jest dokumentem, którego uwaga jest skupiona na stronie wydatkowej i zawiera informacje w zakresie zamierzeń organu wykonawczego, na co zostaną wydatkowane środki publiczne, tj. nie tylko w jakiej wysokości, ale też z podaniem planowanego rezultatu osiągniętego w wyniku dokonanego wydatku. Zatem obejmuje dane mogące służyć do oceny efektywności realizacji zadań. Budżet w układzie zadaniowym wymaga innego podejścia do ewidencji wydatków, niż to ma miejsce w ewidencji tradycyjnej. Ewidencja powinna umożliwić ujęcie wydatków według struktury budżetu, tj. na zadania, podzadania i działania. Wydatki powinny być uporządkowane w sposób umożliwiający ich porównywalność w czasie i pomiędzy różnymi podmiotami sektora finansów publicznych ${ }^{5}$. Do głównych cech budżetu zadaniowego zaliczyć należy: orientacja na wyniki (rezultaty), efektywność, przejrzystość oraz rzetelna informacja o kondycji finansowej samorządu i wydatkowaniu środków budżetowych ${ }^{6}$.

Budżet zadaniowy jest rezultatem tzw. budżetowania programowego wprowadzonego w sektorze publicznym w latach 60. w Stanach Zjednoczonych. Budżet zadaniowy po raz pierwszy w Polsce zastosowało miasto Kraków (1995) oraz ok. 40 gmin ${ }^{7}$. W budżecie zadaniowym są zadania nazwane, opisane i skwantyfikowane pod względem przewidywanych wyników, tj. kosztów i wskaźników efektywności możliwych do osiągnięcia. Budżet ten oparty jest na zasadzie 3 razy E: economy (gospodarność), efficiency (efektywność), effectiveness (skuteczność). Prace nad budżetem zadaniowym w Polsce spowodowały wiele problemów natury metodologicznej i pojęciowej, w ewidencyjnym ujęciu wydatków

5 J. Wąsik, Wydatki budżetowe a koszty realizacji zadań w budżecie zadaniowym, [w:] Budżet zadaniowy metoda racjonalizacji wydatków, (red.) B. Woźniak, M. Postuła, Szkoła Główna Handlowa w Warszawie, Warszawa 2012, s. 105.

6 M. Postuła, Aktualne doświadczenia Austrii we wprowadzaniu budżetu zadaniowego, [w:] Budżet zadaniowy metoda racjonalizacji wydatków, (red.) B. Woźniak, M. Postuła, Szkoła Główna Handlowa w Warszawie, Warszawa 2012, s. 153.

7 Na przykład Szczecin, Ostrów Wielkopolski, Poznań, Lublin, Sandomierz, Koszalin, Zgierz, Starachowice, Mikołajki, Łęczyca, Olecko, Lubań. W Polsce już kilkadziesiąt samorządów stosuje budżetowanie zadaniowe, ale zakres jest zróżnicowany, gdyż w niektórych jednostkach obejmuje pojedyncze obszary działalności, w innych całość. 
budżetowych i powiązania ich z kosztami funkcjonowania jednostek budżetowych oraz oceną efektów realizowanych zadań. Trudno znaleźć, zarówno w literaturze polskiej, jak i zagranicznej, jednoznaczną definicję budżetu zadaniowego (performance budgeting). Zwykle określa się go jako powiązanie wydatków budżetowych z celami. Wprawdzie definicje budżetu zadaniowego podaje zarówno OECD, jak i A. Schick, R. Allen i D. Tommasi oraz T. Lubińska, to wydaje się, że definicja tej ostatniej jest najbardziej odpowiednia. Według T. Lubińskiej budżet zadaniowy to: zarzadzanie środkami publicznymi poprzez cele odpowiednio skonkretyzowane i zhierarchizowane, na rzecz osiagnięcia określonych rezultatów, mierzonych za pomoca ustalonego systemu mierników ${ }^{8}$.

Budżet zadaniowy pozwala ustalić, które zadania są najważniejsze dla realizacji celów oraz za pomocą mierników pokazuje, w jakim stopniu zostały one zrealizowane. Wydatki budżetu zadaniowego klasyfikowane są nie tylko według zadań, ale przede wszystkim przypisane są im efekty, jako kluczowa kategoria budżetu zadaniowego ${ }^{9}$. Powoduje on zatem przejrzystość decyzji i daje obiektywne informacje o efektywności ponoszonych wydatków. Można powiedzieć, że budżet zadaniowy jest instrumentem oceny efektywności pracy. Ocena efektywności wydatków w budżecie zadaniowym odbywa się przez ocenę zastosowanych mierników. Szeroka baza mierników pozwala nie tylko ocenić efektywność wydatków budżetowych, ale także stopień ich realizacji (skuteczność). Umożliwia to prowadzenie aktywnej polityki na przykład przez wprowadzanie korekt w celu osiągnięcia zamierzonych celów. Budżet tradycyjny, skonstruowany według podziałek klasyfikacji budżetowej na części, działy, rozdziały i paragrafy, w porównaniu z budżetem zadaniowym jest mało czytelny i nie uwzględnia celowości i skuteczności ponoszonych wydatków. Budżet zadaniowy wprowadza nowoczesne metody zarządzania środkami publicznymi i jest elementem new public management, w którym wykorzystuje się zasady i modele stosowane w sektorze prywatnym. Należy pamiętać, że budżet jest nie tylko narzędziem zarządzania środkami publicznymi, ale także sposobem komunikacji z mieszkańcami, bowiem daje on wyraz zamierzeń finansowych i programowych danej jednostki samorządu ${ }^{10}$.

Decyzje finansowe $\mathrm{w}$ samorządzie podejmowane są we wszystkich obszarach jego aktywności. Najczęściej podejmowane decyzje skupione są wokół inwestycji strategicznych, finansowania zadań, zarząadzania mieniem komunalnym oraz finansowania deficytu ${ }^{11}$. Do narzędzi zarządzania finansami o charakterze

8 T. Lubińska (red.), Nowe zarządzanie publiczne - skuteczność i efektywność. Budżet zadaniowy w Polsce, Wydawnictwo Difin, Warszawa 2009, s. 41.

9 T. Lubińska, Budżet państwa i budżet zadaniowy w kontekście zasad budżetowych, [w:] Budżet zadaniowy metoda racjonalizacji wydatków, (red.) B. Woźniak, M. Postuła, Wydawnictwo CeDeWu, Warszawa 2012, s. 25.

10 Z. Dolewka, Budżet zadaniowy w gminach jako nowe narzędzie zarządzania finansami samorzq̨dowymi, [w:] Budżet zadaniowy metodą racjonalizacji wydatków..., s. 258.

11 B. Filipiak, Finanse samorzqdowe. Nowe wyzwania bieżace i perspektywiczne, Wydawnictwo Difin, Warszawa 2011, s. 125. 
analitycznym należą: sprawozdawczość, analiza finansowa oraz kontrola i audyt. Sprawozdawczość budżetowa polega na sporządzaniu przez poszczególnych dysponentów środków publicznych, sprawozdań z wykonania planu finansowego. W świetle przepisów prawa, sprawozdawczość jest niezbędnym elementem prowadzenia działalności na potrzeby m.in. rozliczeń podatkowych, kontroli, statystyki itp. Sprawozdania budżetowe i finansowe są ważnym źródłem informacji, ale niestety nie w pełni wystarczającym dla szeregu podejmowanych decyzji, rodzących skutki finansowe, czy ekonomiczne ${ }^{12}$. Sprawozdawczość jednostek samorządu stanowi końcowy etap generowania informacji liczbowych, co daje podstawę dokonywania dalszych analiz i ocen kondycji finansowej tychże jednostek. Obowiązujący system sprawozdawczości posiada wiele wad, które ograniczają jego przydatność $\mathrm{w}$ ocenie sytuacji finansowej samorządu ${ }^{13}$. Jest on nadmiernie rozbudowany (duża szczegółowość), skierowany do wąskiej grupy specjalistów (a przecież gospodarka finansowa jest jawna), której również przysparza trudności w przyjęciu odpowiedniej klasyfikacji budżetowej, pozostawia dużą swobodę w przedstawieniu istotnych informacji (prowadzącą do ogólnych stwierdzeń - dotyczy to sprawozdań opisowych, raportów o stanie gminy) oraz nie obejmuje wszystkich informacji o działalności jednostki samorządowej (zwłaszcza spółek komunalnych).

Analiza finansowa dostarcza informacji niezbędnych do dokonania wyboru, podjęcia decyzji. Podstawą oceny kondycji finansowej samorządu jest analiza zgromadzonego materiału faktograficznego, który obejmuje zbiór dokumentów wymaganych na etapie planowania, a następnie realizacji budżetu. Korzystanie z tych materiałów w analizie finansowej pozwala na ocenę gospodarowania środkami publicznymi. Do zadań analizy finansowej budżetu zalicza się m.in.: informowanie o strukturze dochodów w przekroju źródeł powstawania, kontrolę bieżącą płynności finansowej, równowagi finansowej, ocenę efektywności wydatkowania środków. Z kolei, kontrola porównuje stan faktyczny ze stanem wymaganym, tj. wyznaczonym przez ramy prawa, normy techniczne, ekonomiczne itp. Podstawową funkcją kontroli jest: sprawdzanie, ocenianie i wnioskowanie. Sprawnie działająca kontrola powinna zapewnić m.in.: zgodność działalności z przepisami prawa i wewnętrznymi procedurami, skuteczność i efektywność działania, wiarygodność sprawozdań finansowych i budżetowych, ochronę wszystkich zasobów, efektywność i skuteczność przepływu informacji, przestrzeganie zasad etycznego postępowania, zarządzanie ryzykiem. Kontrola pełni zatem bardzo ważną funkcję w zarządzaniu, m.in. wymuszając efektywność działania ${ }^{14}$.

12 M. Dylewski, B. Filipiak, M. Gorzałczyńska-Koczkodaj, Analiza finansowa w jednostkach samorządu terytorialnego, Wydawnictwo Municipium, Warszawa 2004, s. 65-93.

13 Z. Dolewka, Dokumenty planistyczne i sprawozdawcze do oceny kondycji finansowej gminy, [w:] Finanse i ryzyko w kształtowaniu rozwoju regionu, (red.) M. Dylewski, Zeszyty Naukowe Wyższej Szkoły Bankowej w Poznaniu, nr 41, Poznań 2012, s. 44-45.

14 Z. Dolewka, System kontroli i nadzoru w samorzq̨dzie terytorialnym, „Biblioteka Regionalisty” 2013, nr 13, s. 32-33. 



\section{Rozdział V}

\section{Finansowanie zadań publicznych}

Samorząd terytorialny to jeden z podstawowych segmentów władzy publicznej w Polsce, który realizuje wiele różnorakich zadań publicznych i stanowi najbliższą obywatelowi strukturę administracyjną. Treścią działalności gospodarczej jednostek samorządowych jest wykonywanie zadań publicznych, określonych przepisami prawa ${ }^{1}$. Są one realizowane w celu zaspokajania potrzeb mieszkańców wspólnoty samorządowej. Wśród zadań publicznych samorządu główne znaczenie powinny mieć zadania własne, bowiem stanowią główny element jego działań $^{2}$. Dominująca rola tych zadań jest sensem samorządu, ponieważ należą one do przedmiotu działalności. Ramy i charakter zadań własnych wyznaczają dwa istotne obszary aktywności publicznej. Pierwszym jest zbiór działań, polegających na procesie świadczenia usług publicznych, drugim natomiast zbiór działań nakierowanych na tworzenie warunków rozwoju jednostki samorządowej. Obszary te pozostają wobec siebie w sekwencji, ponieważ od sprawnego świadczenia usług zależy tworzenie rozwiązań rozwojowych. W strukturze zadań dominują zadania własne, o których mowa w tzw. ustawach ustrojowych: o samorzadzie gminnym ${ }^{3}$, o samorządzie powiatowym ${ }^{4}$ i o samorzadzie województwa ${ }^{5}$. Zadania te określają zasadniczy obszar kompetencji jednostek samorządowych. Komplementarną częścią domeny samorządu jest wykonywanie zadań zleconych. Zasadnicza część zadań własnych i zleconych polega na świadczeniu usług, powodując konsekwencje dla ekonomiki i finansów jednostki samorządu.

1 Katalog zadań własnych jest rozległy i wynika z zasady pomocniczości i decentralizacji, a w przypadku gminy otwarty (według zasady domniemania kompetencji).

2 Wskazuje na to art. 166 ust.1 Konstytucji RP z 1997 r., stanowiący, że: „zadania publiczne służace zaspokajaniu potrzeb wspólnoty samorzq̨dowej sq wykorzystywane przez jednostkę samorządu terytorialnego jako zadania własne".

3 Ustawa z dnia 8 marca 1990 r. o samorzadzie gminnym (tekst jednolity: Dz. U. z 2020 r., poz. 713 ze zm.).

4 Ustawa z dnia 5 czerwca 1998 r. o samorządzie powiatowym (tekst jednolity: Dz. U. z 2020 r., poz. 920).

5 Ustawa z dnia 5 czerwca 1998 r. o samorzqdzie województwa (tekst jednolity: Dz. U. z 2020 r., poz. 1668). 
Jak zaznaczono, zadania własne są głównym przedmiotem samorządu, wynikającym $z$ jego natury, ponieważ ich liczba i zakres determinowane są potrzebą istnienia samorządu w ogóle. Przegląd zadań własnych pozwala zgrupować je w kilka bloków tematycznych. Nawiązując do podziału przedstawionego przez E. Wojciechowskiego można wyodrębnić zadania dotyczące:

- infrastruktury technicznej,

- infrastruktury społecznej,

- ładu przestrzennego i ekologicznego,

- porządku i bezpieczeństwa publicznego,

- pozostałe ${ }^{6}$.

Cechą charakterystyczną w samorządności jest zamknięty katalog zadań dla powiatów i województw, a otwarty dla gmin. Stwarza to możliwość przekazywania, przez administrację rządową, nowych zadań publicznych (lub rozszerzenie zakresu dotychczasowych zadań) na szczebel gmin. W związku z tym można powiedzieć, że proces decentralizacji zadań wciąż trwa. Właściwością większości zadań własnych samorządu jest ich szczególny charakter - użyteczności publicznej. Ustawodawca zdefiniował użyteczność publiczną jako: bieżące i nieprzerwane zaspokajanie zbiorowych potrzeb ludności $w$ drodze świadczenia usług powszechnie dostępnych7. $\mathrm{Z}$ treści definicji wynika specyfika działania w samorządzie, określająca pewne rygory w przedmiocie działalności gospodarczej.

Z punktu widzenia finansowego, istotnym podziałem jest wyodrębnienie wśród zadań własnych, zadań o charakterze obligatoryjnym (obowiązkowym) oraz fakultatywnym (dowolnym). Jednostki samorządu muszą wykonywać zadania własne obowiązkowe, które zostały uznane przez ustawodawcę za konieczne dla trwałości istnienia struktury samorządowej. Pierwszą ułomnością prawną w obszarze przekazywania zadań jednostkom samorządowym jest ich rozproszenie w wielu regulacjach prawnych bez wskazania, które są obligatoryjne. Drugą ułomnością jest jedynie częściowe określenie standardu wykonywania tego typu zadań. Standard taki charakteryzuje wymiar jakościowy realizacji zadania, rzutujący na zakres, technologie i proces zaspokajania zbiorowych potrzeb ludności.

Specyfikacja zadań własnych obligatoryjnych powoduje istotną implikację dla polityki organów samorządowych. W pierwszym rzędzie, priorytetem jest sfinansowanie wykonania tych zadań, zaś w przypadku zadań pozostałych ich realizacja będzie możliwa, jeśli jednostkę samorządową będzie na to stać pod względem finansowym. Ważną implikacją jest też elastyczność w podejmowaniu decyzji przez władze, polegająca na preferowaniu realizacji zadań fakultatywnych kosztem zadań obligatoryjnych. Preferencja zadań fakultatywnych powoduje zmniejszenie całkowitego kosztu wykonania zadań obligatoryjnych (mniejsze wydatki w budżecie). Następstwem tego są skutki w postaci

6 E. Wojciechowski, Gospodarka samorzq̨du terytorialnego, Wydawnictwo Difin, Warszawa 2012, s. 33.

7 Art. 1 ust. 2 ustawy z dnia 20 grudnia 1996 r. o gospodarce komunalnej (tekst jednolity: Dz. U. z 2019 r., poz. 712 ze zm.). 
ograniczenia zakresu wykonywania zadań i obniżenia jakości usług komunalnych. Nie są to jednak skutki negatywne, jeśli posunięcie to znajdzie aprobatę wśród mieszkańców. W ten sposób wygenerowane nakłady finansowe mogą być przeznaczone na wybrane zadania fakultatywne. Należy to tłumaczyć (w dużym stopniu) presją mieszkańców, oczekujących podjęcia realizacji niektórych zadań fakultatywnych i uzyskania szybkiej korzyści z tytułu ich wykonania. Zwykle sytuacja taka ma miejsce w mniej zamożnych samorządach, gdyż bogatsze mają większe możliwości sfinansowania zadań fakultatywnych. Świadomość swoistej gry między finansowaniem zadań własnych obligatoryjnych oraz fakultatywnych powinna być powszechna wśród decydentów samorządowych.

Dylemat ten nie występuje w podziale zadań samorządu na własne i zlecone. Te ostatnie są finansowane $\mathrm{z}$ budżetu państwa przez przekazanie odpowiednich dotacji celowych. W tym obszarze występuje jednak problem natury finansowej, w postaci niedoboru środków finansowych na realizację przekazanych zadań zleconych przez administrację rządową. Niedobór ten samorządy pokrywają własnymi środkami, niejednokrotnie kosztem realizacji zadań własnych. Zdarza się również, że samorządy w obliczu niewystarczających nakładów finansowych na zadania zlecone, zmniejszają zakres rzeczowy tych zadań (choć nie zawsze jest to możliwe, np. urzędy stanu cywilnego). Zadania zlecone mocą ustaw mają charakter obligatoryjny, natomiast zlecone na podstawie porozumień są fakultatywne, a ich przyjęcie zależy od swobodnej decyzji samorządu. W strukturze zadań zleconych przeważają zadania obligatoryjne (wynikające $\mathrm{z}$ ustaw). Wymiar finansowy realizacji zadań zleconych jest jednoznaczny, „sztywny”, ponieważ jest kształtowany dotacyjnym charakterem środków. Jednostka samorządowa wykonująca zadania zlecone musi rozliczyć się z wykorzystania przekazanych środków (dotacji) i podlega kontroli ze strony administracji rządowej w zakresie gospodarności, celowości, rzetelności i legalności.

Już z samego wyliczenia zadań własnych wynika ich zakres przedmiotowy i charakter, a następnie zaznacza się sprzeczność wartości, które mają być osiągnięte w wyniku ich realizacji. W wykonywaniu tych zadań należy dążyć do harmonizowania kolizyjnych wartości (sprawiedliwość i efektywność). Typowymi zadaniami własnymi są usługi w zakresie zaopatrzenia w wodę i odprowadzania ścieków oraz usługi transportowe obejmujące komunikację publiczną oraz drogi. Są to ewidentne usługi o charakterze infrastrukturalnym, stanowiące podstawę funkcjonowania i rozwoju samorządu. W ich świadczeniu występuje wspomniana sprzeczność wartości takich jak: zapewnienie dostępności przestrzennej tej infrastruktury oraz efektywność w ich budowie i użytkowaniu. Inną wersją tych sprzeczności jest zasada solidarności społecznej.

Przykładem może być rozbudowa miasta poprzez lokalizację nowych osiedli mieszkaniowych, znajdujących się na obrzeżach samorządu, wymagająca wysokich nakładów inwestycyjnych, obciążających budżet. $Z$ reguły wiąże się to $\mathrm{z}$ rozbudową infrastruktury sieciowej, przy rozproszonej zabudowie, co kłóci się z kryteriami efektywności ekonomicznej (korzyści skali). Dodatkowo, korzyści z nowej 
infrastruktury ograniczone są tylko do części mieszkańców wspólnoty, której koszt pokrywają wszyscy obywatele samorządu' łeczna adresowana do osób, znajdujących się w trudnej sytuacji dochodowej. Kolizja wartości oznacza wspomaganie grupy słabszych jednostek przez pozostałych mieszkańców samorządu, których potrzeby w ten sposób są zaspokojone w niższym stopniu. Zbliżona sytuacja występuje w zakresie świadczenia usług kultury, kiedy ogół mieszkańców wspiera możliwość korzystania z nich przez ograniczoną liczbę zainteresowanych mieszkańców nie tylko z rodzimego samorządu9 .

Zadania publiczne definiowane przez ich zakres i charakter mają wyraz przedmiotowy w procesie ich wykonywania. Realność zadań, rozumiana jako ich realizacja, wymaga użycia odpowiednich do tego środków działania. Użycie środków dla realizacji zadań, powinno być zgodne z wymienioną już zasadą adekwatności, tj. wielkość zastosowanych środków powinna odpowiadać wielkości danego zadania publicznego. Środki realizacji zadań nie są jednorodne i obejmują dwie grupy:

- środki o charakterze zasobu gospodarczego,

- środki o charakterze instrumentalnym (bodźce ekonomiczne).

Pierwsza grupa środków to czynniki procesu wytwórczego, dzięki którym następuje transformacja ograniczonych zasobów w strumien dóbr, przybierających formę produktów i usług publicznych. Środki instrumentalne są narzędziami ekonomicznymi dostarczającymi informacji, w jakim kierunku i w jakim zakresie, należy zastosować zasoby gospodarcze w działalności gospodarczej? Standardowymi instrumentami są następujące wielkości ekonomiczne: cena, płaca, amortyzacja, podatek, opłata, koszt itd. $\mathrm{W}$ istocie środkami realizacji zadań publicznych są również metody wykorzystania dostępnych zasobów gospodarczych w procesie osiągania celów, czyli wykonania konkretnego zadania publicznego. Zastosowanie określonych metod determinuje skuteczność realizacji zadania publicznego. Należy podkreślić, że za realizację zadań samorządu odpowiada bezpośrednio organ wykonawczy w każdej jednostce. W gminach, mamy do czynienia z podwójną odpowiedzialnością wójta, burmistrza, prezydenta miasta. Po pierwsze, będąc wybrany demokratycznie przez uprawnionych mieszkańców gminy, jest przez nich oceniany i rozliczany. Po drugie, w zakresie realizacji zadań własnych samorządu podlega ocenie organu stanowiącego (radzie). W związku z tym, o organizacji i sposobach wykonywania zadań publicznych w samorządzie decyduje w większości organ wykonawczy.

8 W pewnym stopniu sytuacja podobna jest do tzw. efektu gapowicza (free rider problem) w teorii ekonomii.

9 Dobrym przykładem problemu gapowicza jest tódzkie lotnisko należące w większości do mieszkańców miasta (ok. 95\%), z którego korzystali i jeszcze korzystają mieszkańcy z całego regionu. Prawie całkowita własność komunalna lotniska jest ewenementem w skali kraju (wcześniej też Radom). W dalszym ciągu „ścierają się" racje ekonomiczne i społeczne, ponieważ te pierwsze opowiadają się za istnieniem lotniska jako czynnika miastotwórczego (dostępne dla inwestorów i turystów) finansowanego z budżetu przez łodzian, drugie natomiast dotyczą ogółu mieszkańców województwa łódzkiego. 
W strukturze władz samorządu gminnego, organ wykonawczy zajmuje dominującą pozycję ekonomiczną i ustrojową, przede wszystkim ze względu na legitymizację demokratyczną, szeroki zakres kompetencji oraz monokratyczny (jednoosobowy) charakter. Wytwarzanie produktów i usług publicznych w samorządzie jest treścią, a zarządzanie formą. Stąd też, proces zarządzania powinien być w gestii organu wykonawczego, natomiast wytwarzanie dóbr komunalnych (z racji, że przynależy do sfery gospodarowania) należy do obszaru administracji samorządowej. Administracja ta może bezpośrednio zajmować się dostarczaniem usług, czyli być: organizatorem, moderatorem, wykonawcą (np. usług administracyjnych), jak też być koordynatorem w procesie świadczenia usług (w zakresie usług technicznych i częściowo społecznych). W ostateczności pełną odpowiedzialność za dostarczenie usług komunalnych ponosi i tak organ wykonawczy (o czym mowa była wcześniej).

Większość zadań własnych posiada charakter użyteczności publicznej, co nakazuje ich wykonywanie w szczególnym reżimie prawnym i ekonomicznym. Usługi publiczne zaspokajają podstawowe potrzeby społeczne - ujawniające się $\mathrm{w}$ sposób masowy - które są elementarne dla życia ludności. Proces zaspokajania tych potrzeb musi być ciągły i bezpieczny, a usługi komunalne powinny być dostępne w sensie przestrzennym i ekonomicznym. Samorząd reprezentowany przez jego organy oraz służby publiczne ma swobodę wyboru formy organizacyjnej realizacji większości zadań własnych. Pole potencjalnych wyborów zakreślają następujące formy organizacyjno-prawne prowadzenia działalności gospodarczej w wykonywaniu zadań publicznych:

- budżetowe, nieposiadające osobowości prawnej, w postaci jednostek budżetowych i samorządowych zakładów budżetowych;

- podmioty gospodarcze posiadające osobowość prawną, wyodrębnione z administracji samorządowej, działające jako spółki prawa handlowego;

- podmioty należące do sektora prywatnego i sektora społecznego;

- współpraca z innymi jednostkami samorządu terytorialnego.

Każda $\mathrm{z}$ tych form charakteryzuje się odmiennym zakresem i różną efektywnością $\mathrm{w}$ realizacji zadań własnych. Dwie pierwsze, oznaczają wykonywanie zadań $\mathrm{w}$ formule samowystarczalnej (własnymi siłami). Trzecia forma zbliżona do rozwią zania outsourcingowego polega na zlecaniu świadczenia usług na zewnątrz struktury samorządu. Praktyka dowodzi, że w polskich samorządach dominuje mieszany model realizacji zadań publicznych ${ }^{10}$.

Działalność bieżącą (użytkowanie i eksploatację obiektów użyteczności publicznej) i działalność inwestycyjną (rozwojową) należy traktować łącznie. Całkowity koszt realizacji zadania publicznego obejmuje koszty powstające w sferze eksploatacji majątku komunalnego oraz koszty z tytułu przeprowadzenia inwestycji

10 Szerzej o efektywności form organizacyjnych w samorządzie pisze autorka, Zarządzanie w jednostkach organizacyjnych gminy, [w:] Efektywność zarzq̨dzania organizacjami publicznymi i jej pomiar, (red.) A. Frączkiewicz-Wronka, Zeszyty Naukowe Wydziałowe Uniwersytetu Ekonomicznego w Katowicach, Katowice 2013, s. 40-51. 
w zakresie odtworzenia, rozbudowy, budowy i modernizacji elementów materialnych oraz niematerialnych, składających się na zasób majątkowy samorządu. Można stwierdzić, że działalność inwestycyjna zorientowana na rozwój wynika z oceny możliwości wykorzystania istniejących zdolności produkcyjnych lub usługowych, posiadanych przez struktury samorządowe. Działalność bieżąca samorządu może być rentowna, generująca nadwyżkę (zysk) ponad koszty działalności. Środki stąd pochodzące stanowią pierwsze źródło finansowania działalności inwestycyjnej (wydatków majątkowych). Wartość tą odzwierciedla kategoria nadwyżki operacyjnej, jako dodatni wynik różnicy między dochodami bieżącymi a wydatkami bieżącymi jednostki samorządowej. W Polsce, parametr ten jako wymóg prawny został wprowadzony w życie w 2010 r., mocą ustawy o finansach publicznych. Zastosowanie tego parametru ma na celu formalne skłonienie samorządu do racjonalizacji działalności bieżącej, przez wypracowanie nadwyżki środków (uzyskanie wyższych dochodów od wydatków), zazwyczaj z przeznaczeniem na działalność inwestycyjną lub spłatę rat wcześniej zaciągniętych zobowiązań dłużnych. Osiągnięcie tego jest możliwe przez dyscyplinowanie i reżim w polityce wydatkowej działalności bieżącej. Zwykle wypracowanie dodatniego wyniku finansowego na tej działalności nie wystarcza na zaspokojenie potrzeb inwestycyjnych (choć stanowi istotny wskaźnik gospodarki finansowej jednostki), bowiem samorząd od początku boryka się z trudnościami związanymi z ograniczonymi finansami a potrzebami rozwojowymi w poprawie życia mieszkańców wspólnoty terytorialnej.

W związku z tym, władze samorządu zmuszone są poszukiwać innych źródeł pozyskania środków finansowych na cele inwestycyjne, kierując się kalkulacją wielu racji. Mimo dość umiarkowanej liczby możliwych źródeł, odznaczających się różnym ryzykiem i wpływem na bezpieczeństwo finansowe samorządu, wydaje się, że najlepsze $\mathrm{z}$ tego punktu widzenia są instrumenty tradycyjne takie jak: dotacja celowa, kredyt i pożyczka, obligacje (w tym przychodowe) i w niektórych przypadkach amortyzacja ${ }^{11}$. W rachubę wchodzi też rozwiązanie w formule montażu finansowego w ramach partnerstwa publiczno-prywatnego (PPP), ewentualnie leasingu zwrotnego (finansowego) ${ }^{12}$. Z wyjątkiem amortyzacji i dotacji celowych oraz PPP, pozostałe narzędzia finansowe mają charakter zwrotny (dłużny). Cechą ich jest zaciąganie zobowiązania finansowego, skutkującego tworzeniem długu publicznego. Jego wielkość determinuje warunki płynności finansowej samorządu i szerzej - kondycję gospodarki samorządowej. Pozyskanie środków w strukturze partnerstwa $\mathrm{z}$ sektorem prywatnym wymaga dużego wysiłku organizacyjnego, wiedzy i wysokich kwalifikacji. Podjęcie współpracy w tej mierze polega na akceptacji rozkładu ryzyka między stronami umowy. Duża pracochłonność procedury PPP powoduje, że samorządy są powściągliwe w przejawianiu się tego typu inicjatyw

11 Jednostki samorządowe kalkulują nadwyżkę operacyjną i pozostałe pozycje np. w sprawozdaniu budżetowym RbNDS w oparciu o przepływy gotówkowe.

12 Leasing zwrotny może mieć charakter leasingu operacyjnego, niezaliczonego do tytułów dłużnych, albo leasingu finansowego zaliczanego do tytułów dłużnych. 
gospodarczych. Bez wątpienia, sedno PPP zawiera się w połączeniu dwóch oddzielnych logik: publicznej zorientowanej na wartość publiczną i prywatnej obliczonej na uzyskanie zadowalającego zysku dla przedsiębiorcy prywatnego. Ten ostatni jest skłonny zaangażować swój majątek w przedsięwzięcie pod warunkiem, że przyniesie mu odpowiednią (oczekiwaną) stopę zysku, wyższą niż oferują np. instytucje finansowe.

Celem realizacji zadań własnych samorządu jest kształtowanie warunków dla zaspokajania potrzeb społecznych mieszkańców, tworzących wspólnotę samorządową. Zadania własne charakteryzują się dwoma atrybutami:

- mają charakter publiczny,

- polegają na działalności usługowej.

Publiczny charakter zadań oznacza, że są one wykonywane w sposób masowy dla zaspokajania potrzeb ludności, ujawniających się również w sposób powszechny. Wykonywanie zadań własnych odbywa się w procesie dostarczania (świadczenia) tych zadań w formie usługi publicznej. Nawet tam, gdzie mamy do czynienia z wytworzeniem określonego produktu, to jego ostateczne dostarczenie nabywcy - lub konsumentowi - ma miejsce w procesie usługowym.

Zadania zlecone jednostce samorządowej stanowią, równoległy do zadań własnych, obszar ich działalności. Są to zadania publiczne należące do obowiązków państwa, lecz przekazywane do wykonywania samorządowi przez administrację rządową. Istotą tych zadań publicznych jest ich znaczenie dla sprawności i stabilności funkcjonowania państwa, a jednocześnie miejscowy i lokalny charakter. W związku z tym, administracja rządowa w imieniu państwa zleca te zadania jednostkom samorządu, przede wszystkim powiatom i gminom w przekonaniu, że bliskość świadczonej usługi w stosunku do obywatela pozwoli na efektywniejsze wykonanie zadania. Przekazanie zadania zleconego związane jest z zapewnieniem środków finansowych równoważnych do treści i zakresu zadania. W obszarze zadań zleconych występuje podwójna odpowiedzialność. Odpowiedzialność formalną za zadanie zlecone ponosi administracja rządowa, natomiast odpowiedzialność merytoryczna spada na podmiot bezpośrednio wykonujący ten typ zadania publicznego. Swoistym łącznikiem między tymi odpowiedzialnościami są środki finansowe oraz nadzór i kontrola ze strony administracji rządowej. Przekazywanie zadań zleconych „z góry na dół”, nie należy traktować jako formy decentralizacji zadań państwa, ponieważ zadania zlecone pozostają dalej w gestii administracji rządowej. 



\section{Rozdział VI}

\section{Budżet jako podstawa wykonywania zadań publicznych}

W świetle prawa, budżet jest rocznym planem finansowym obejmującym dochody i wydatki oraz przychody i rozchody ${ }^{1}$. Jego główną właściwością jest obligatoryjny charakter dla wszystkich jednostek samorządowych. Zdaniem autorki, budżet ze swej natury jest zawsze zrównoważony, ponieważ suma dochodów i przychodów jest taka sama jak suma wydatków i rozchodów. Jest on zrównoważony również, gdy wystąpi nadwyżka, czyli suma dochodów i przychodów jest większa od sumy wydatków i rozchodów². Szczególną wersją zrównoważenia może być część budżetu, zestawiająca same dochody i wydatki, dające saldo zerowe. Ustawodawca określił terminy, w których należy uchwalić taki dokument finansowy, a także przewidział sytuację, kiedy to jednostka samorządowa nie uchwali budżetu w ustawowym terminie. Wtedy obowiązek ten przejmuje instytucja nadzoru finansowego, którą w Polsce dla samorządów są regionalne izby obrachunkowe. Przyjęcie budżetu w każdym samorządzie stanowi warunek sine qua non jej funkcjonowania, a zatem wykonywania zadań własnych. Łatwo zauważyć, że budżet stanowi najgłówniejszy dokument, zapewniający rozpoczęcie i prowadzenie gospodarki finansowej $\mathrm{w}$ jednostce samorządu. Równocześnie budżet warunkuje podjęcie pozostałych aktywności gospodarczych w strukturach samorządu. Z punktu widzenia oceny strukturalnej budżetu, najistotniejsze są dwa logiczne przekroje oceny:

- strona dochodowa, gdzie chodzi o jak największą wydajność wybranych źródeł dochodów,

- strona wydatkowa, w której chodzi o racjonalność poniesionych wydatków, w tym uzyskanie jak największej ich efektywności.

1 Art. 211 ust. 1 ustawy z dnia 27 sierpnia 2009 r. o finansach publicznych (tekst jednolity: Dz. U. z 2019 r. poz. 869 ze zm.)

2 Mimo że w praktyce gospodarczej mówi się o budżecie deficytowym, to w piśmiennictwie uważa się, że budżet może być tylko zrównoważony, nawet jeśli wystąpi nadwyżka; S. Owsiak, M. Kosek-Wojnar, K. Surówka, Równowaga budżetowa: deficyt budżetowy, dług publiczny, Państwowe Wydawnictwo Naukowe, Warszawa 1993, s. 57-58. Zasada zrównoważenia budżetu wynika z przepisów prawa. 
Konstytucja RP stanowi w art. 167, iż dochodami jednostek samorządu terytorialnego są:

- dochody własne (podstawowe źródło dochodów samorządu),

- subwencja ogólna i dotacje celowe z budżetu państwa (dochody uzupełniające).

Dochody własne stanowią podstawę wyposażenia finansowego samorządów i służą finansowaniu zadań własnych samorządu. Warto dodać, że podstawową regułą konstytucyjną dotyczącą wyposażenia samorządów w odpowiednie źródła dochodów jest zasada adekwatności przydzielonych samorządom dochodów do nałożonych na jednostki samorządu zadań publicznych, która określa, że: jednostkom samorządu terytorialnego zapewnia się udział $w$ dochodach publicznych odpowiednio do przypadających im zadań3. Stąd można powiedzieć, że dochody samorządowe są funkcją przekazywanych samorządom zadań - zarówno co do ich charakteru, jak i ich rozmiarów (zakresu rzeczowego). Sama zasada adekwatności sugeruje odpowiedniość środków finansowych w stosunku do założonych celów w polityce finansowej samorządu. W teorii ekonomii wykorzystuje się tzw. automatyczne stabilizatory koniunktury, do których należą podatki od dochodów ludności. W okresie recesji hamują one spadek popytu, zaś w okresie ekspansji hamują jego wzrost ${ }^{4}$.

Dochody własne, o których mówi Konstytucja RP, mają formę podatków lokalnych, przekazanych ustawowo do dyspozycji samorządów (podatek od nieruchomości, od środków transportowych, rolny, leśny, od spadków i darowizn, od czynności cywilno-prawnych, dochodowy od osób fizycznych, opłacany w formie karty podatkowej) i opłat komunalnych (opłata skarbowa, targowa, miejscowa, uzdrowiskowa, od posiadania psów, reklamowa, za gospodarowanie odpadami komunalnymi), a także udziałów w podatkach dochodowych od osób fizycznych (PIT) i od osób prawnych (CIT) oraz dochodów majątkowych. Jednostki samorządowe (głównie gminy) mają prawo ustalania wysokości podatków i opłat lokalnych w zakresie określonym w przepisach prawa. Oznacza to, że samorząd może samodzielnie kształtować przypisane mu źródła dochodowe, mające postać podatku lub opłaty, w przedmiocie ich wysokości. James M. Buchanan zwraca uwagę, że podatki i opłaty powinny być w ostateczności traktowane jako swoisty koszt dóbr i usług publicznych, przysparzających korzyści podatnikom ${ }^{5}$.

W strukturze dochodów własnych znajduje odbicie charakter bazy podatkowej. W gminach miejsko-wiejskich oraz miejskich, głównym źródłem dochodów własnych są udziały w podatku dochodowym oraz z podatku od nieruchomości. W gminach wiejskich na plan pierwszy wysuwa się dochód z tytułu podatku od nieruchomości oraz podatku rolnego. W powiatach, dominującą pozycją jest udział we wpływach z PIT, zaś w województwach - we wpływach z CIT. W zakresie dochodów z ostatnich źródeł, samorządy nie posiadają żadnych uprawnień

3 Art. 167 ust. 1 Konstytucji RP...

4 R. Milewski (red.), Podstawy ekonomii, Wydawnictwo Naukowe PWN, Warszawa 1998, s. 444.

5 James M. Buchanan, Finanse publiczne w warunkach demokracji, Wydawnictwo Naukowe PWN, Warszawa 1997, s. 115 i 123-124. 
podatkowych ${ }^{6}$. Wielkość dochodów własnych w małym stopniu opiera się na wpływach z podatków lokalnych. Samorząd nie dysponuje realnym władztwem podatkowym w obszarze opłat i podatków lokalnych. O ograniczonym władztwie można mówić tylko w gminach i dotyczy to podatków: od nieruchomości, od środków transportowych, rolnego i leśnego. Udział w podatkach budżetu państwa (PIT i CIT) jest zaliczany do dochodów własnych, ale tylko teoretycznie - w rozumieniu ustawy o dochodach jednostek samorzadu terytorialnego ${ }^{7}$. Niski poziom dochodów własnych w budżetach sprawia, że samorząd traci autonomię finansową. Dla zwiększenia dochodów własnych, gminy decydują się na podnoszenie podatków i opłat lokalnych. Wyższe są opłaty za wodę, ścieki, ciepło, za parkowanie, za przedszkola, czynsz za mieszkania komunalne oraz ceny biletów komunikacji zbiorowej i energii cieplnej. Prowadzi to jednak do spadku popytu na te usługi publiczne, a po pewnym czasie do stabilizacji, gdyż usługi te odznaczają się niską cenową elastycznością popytu.

Drugą grupą dochodów samorządu są transfery zewnętrzne: subwencja ogólna i dotacje celowe. Transfery zewnętrzne stanowią bezzwrotną pomoc finansową (wsparcie dla działalności). Subwencja skierowana jest na finansowanie zadań własnych i przekazywana przez ministra finansów w odpowiednich ratach. Składa się z trzech części: oświatowej, wyrównawczej i równoważącej. Dotacje celowe przekazywane są jednostkom samorządowym z budżetu państwa (z reguły przez wojewodę) na realizację zadań zleconych, ale też na finansowanie lub dofinansowanie zadań własnych samorządu. Dotacje celowe pochodzą też od różnych jednostek dotujących, $\mathrm{w}$ tym $\mathrm{z}$ budżetu Unii Europejskiej, z różnych funduszy celowych krajowych i zagranicznych. W zakresie dotacji, środki przekazywane są na konkretny cel (zadanie, przedsięwzięcie). Beneficjent tych środków musi spełnić warunki określone przez dotującego i rozliczyć się z otrzymanych środków finansowych. Pomoc w formie dotacji jest instrumentem finansowym dla samorządu terytorialnego w Polsce, jednak ich adresowość zmniejsza elastyczność w działaniu i swobodę w zagospodarowaniu tych środków publicznych.

Trzeba zaznaczyć, że wymienione dochody samorządu należą do dochodów publicznoprawnych, gdyż pochodzą ze źródeł o charakterze publicznym. Przypadają jednostkom samorządowym na podstawie stosunku prawnego o charakterze publicznym. Prawo do wykorzystywania tych dochodów uzyskują samorządy bezpośrednio z mocy przepisów prawa, przydzielających im określone podatki, udziały w podatkach, opłaty, dotacje i subwencje ${ }^{8}$. Natomiast do dochodów prywatnoprawnych uzyskiwanych przez samorząd należą m.in.

6 Niektóre samorządy planując budżet na 2014 r., by wykazać, że mieszczą się w nowych ramach ustawy o finansach publicznych, zakładały w swych budżetach wyższe wpływy z podatku PIT i CIT oraz ze sprzedaży mienia komunalnego. Te nierealne założenia pozwoliły im uchwalić budżet na 2014 r.

7 Ustawa z dnia 13 listopada 2003 r. o dochodach jednostek samorzqdu terytorialnego (tekst jednolity: Dz. U. z 2020 r., poz. 23 ze zm.).

8 Ibidem, art. 4-8. 
czynsze z najmu i dzierżawy, wpływy ze sprzedaży nieruchomości. Dochody prywatnoprawne pochodzą ze źródeł dochodów o charakterze prywatnym. Jednostka samorządu osiąga je wykorzystując (jako właściciel majątku) należące do niej mienie komunalne. Samorząd może poszczególne jego składniki wynająć, wydzierżawić, czy oddać w użytkowanie wieczyste. Dochody z tego tytułu uzyskiwane są na podstawie zawieranych umów cywilnoprawnych bądź innych czynności prywatnoprawnych.

W polskim samorządzie dominują budżety opracowywane metodą tradycyjną ${ }^{9}$. Jest to metoda sprawdzona i w świetle przepisów prawa nadal obowiązująca, choć skomplikowana i trudna do zrozumienia. Czyni to budżet mało czytelnym i przejrzystym (szczególnie w dużych samorządach), jak też mało komunikatywnym i niejasnym, hermetycznym (zrozumiałym tylko dla wąskiej grupy, tj. specjalistów, którzy uczestniczą przy sporządzaniu tego dokumentu). Uwagi te nabierają szczególnego znaczenia w kontekście prawnego wymogu, iż gospodarka finansowa jest jawna i podlega upublicznieniu. Wydaje się, że jawność przy niezachowaniu przejrzystości i czytelności jest bezcelowa. Struktura budżetu jest zorganizowana wokół odpowiednich podziałek klasyfikacji budżetowej, według klucza: przedmiot - wydatek. W dużych samorządach (miasta na prawach powiatu) niektóre wydatki budżetowe na konkretny cel (np. wynagrodzenia dla pracowników administracji samorządowej, promocja jednostki, wyjazdy służbowe) zapisane są pod różnymi pozycjami (inny dział, rozdział) klasyfikacji budżetowej. Utrudnia to przeprowadzenie analizy i dokonanie oceny, ile łącznie przeznacza się środków publicznych na konkretny cel (zadanie)? Jak słusznie zauważa G. Kozuń-Cieślak, dobry proces budżetowy jest czymś więcej niż tylko przygotowaniem dokumentu prawnego, przypisującego fundusze do odpowiednich pozycji klasyfikacji budżetowej. Jest szeroko zdefiniowanym procesem, który ma wymiar polityczny, menedżerski, planistyczny, komunikacyjny i finansowy ${ }^{10}$.

Podsumowując rozważania należy podkreślić, że podstawową zasadą konstytucyjną dotyczącą wyposażenia samorządu w odpowiednie źródła dochodów jest zasada adekwatności przydzielonych dochodów do nałożonych na jednostki samorządu zadań publicznych. Niezależnie od dochodów, w budżecie mogą występować jeszcze inne wpływy, np. pożyczki, kredyty, środki ze sprzedaży papierów wartościowych wyemitowanych przez jednostkę samorządu, czyli przychody budżetowe. Ich znamienną cechą jest to, że służą finansowaniu deficytu budżetowego, czyli sytuacji, gdy dochody budżetowe jednostki samorządowej są zbyt małe w stosunku do założonych wydatków budżetowych.

Drugim elementem systemu finansów publicznych są wydatki. Podstawowym narzędziem kształtowania wydatków publicznych jest ich planowanie. Plany wydatków publicznych stanowią integralną część budżetu państwa, samorządów

9 Jest to najbardziej powszechna postać budżetu, wykorzystywana szeroko przez wszystkie samorządy na całym świecie.

10 G. Kozuń-Cieślak, Budżetowanie w jednostkach samorządu terytorialnego - reorientacja z administrowania na zarządzanie, „Finanse Komunalne” 2010, nr 9. 
i publicznych funduszy celowych. Według kryterium rodzajowego, wydatki budżetowe dzieli się na bieżące i majątkowe. Wydatki bieżące dokonywane są w ramach działalności bieżącej, na świadczenie usług publicznych, w tym na utrzymanie i eksploatację obiektów oraz urządzeń infrastruktury technicznej i społecznej. Z kolei planowanie i ponoszenie wydatków majątkowych związane jest $\mathrm{z}$ działalnością inwestycyjną (rozwojową) samorządu. Art. 216 ust. 2 ustawy o finansach publicznych stanowi, że wydatki budżetu samorządu, mogą służyć wyłącznie finansowaniu zadań publicznych.

W świetle klasyfikacji budżetowej wydatki publiczne mają charakter rodzajowy (przedmiotowy), bowiem dotyczą istotnych dziedzin (działów) gospodarki samorządu. Strona wydatków budżetu informuje o sposobie rozdysponowania i podziale dochodów na poszczególne zadania publiczne. O ile wielkość dochodów budżetu jest środkiem w polityce finansowej, to wydatki obrazują proces zaspokajania potrzeb wspólnoty i związanych z tym celów, tej polityki. Wielkość i struktura wydatków przedstawia kierunki i preferencje w polityce rozwoju oraz odzwierciedla charakter zadań własnych. Badając stronę wydatków w budżetach, ich analiza i ocena muszą być zgodne z klasyfikacją budżetową (działy, rozdziały, paragrafy). Obserwacja kształtowania się wielkości i struktury wydatków, według kluczowych podziałów, zorientowana jest na uzyskanie dwóch efektów. Po pierwsze, pozyskanie wiedzy o priorytetach przyjętych w polityce rozwoju oraz o ciężarze gatunkowym (znaczeniu) poszczególnych grup wydatków. Po drugie, uzyskanie informacji o celowości dokonania określonych wydatków. B. Guziejewska wskazuje na cztery kierunki racjonalizacji wydatków publicznych (efektywniejsze planowanie budżetowe, ograniczenie kosztów obsługi długu, racjonalizację rozwiązań legislacyjnych oraz decentralizację gospodarowania środkami) ${ }^{11}$. Kolejna grupa informacji, dotyczy wydatków bieżących i majątkowych oraz struktury wydatków bieżących (w tym udziału wynagrodzeń wraz z pochodnymi). Istotny dla obserwacji jest udział wydatków majątkowych, pozwalający na ocenę stopnia zaangażowania się w działalność inwestycyjną. Wszystko to tworzy przesłanki dla oceny efektywności wydatków budżetowych. Według B. Filipiak, analiza efektywności wydatków publicznych polega na badaniu, jak wydawane są środki z budżetu, przez poszczególnych jego dysponentów ${ }^{12}$.

Prawie wszystkie samorządy wykazują wydatki bieżące na zadania oświatowe, wyższe od otrzymanych środków z tytułu części oświatowej subwencji13. Gminy i powiaty najwięcej środków w swoich budżetach przeznaczają na oświatę i wychowanie (ok. 30-35\% wydatków bieżących). Drugim wydatkiem są zwykle nakłady na pomoc społeczną. Trzecim wydatkiem budżetu gminy pod względem wielkości

11 B. Guziejewska, Finanse publiczne wobec wyzwań globalizacji..., s. 105-106.

12 B. Filipiak, Efektywność w zarzq̨dzaniu finansami samorzq̨owymi. Skutek kryzysu czy obiektywna konieczność?, Polskie Towarzystwo Ekonomiczne, Zeszyty Naukowe Nr 10, Kraków 2011, s. 229.

13 Najwyższy wzrost wydatków bieżących na oświatę w relacji do subwencji oświatowej występuje w miastach na prawach powiatu. 
jest utrzymanie władzy i administracji gminy (często zbliżonym do wydatków na pomoc społeczną). Wydatki na utrzymanie władzy i administracji, w zależności od typu jednostki, angażują od 8 do 10\% środków przeznaczonych na wydatki bieżące ${ }^{14}$. Niektóre mniejsze samorządy chcąc ograniczyć swoje wydatki likwidują np.: szkoły, straże miejskie oraz niektóre zakłady budżetowe. W samorządach występuje widoczny wzrost wydatków bieżących (podobnie jak dochodów bieżących). Według tabeli 9 (w załączniku) najwyższy udział wydatków bieżących w ostatnich latach występuje we wszystkich typach samorządu, z wyjątkiem województw (ok. 60-70\%). Na wzrost wydatków bieżących istotny wpływ mają trzy czynniki: wzrost kosztów energii i paliwa, wynagrodzeń dla nauczycieli oraz zatrudnionych z minimalnym wynagrodzeniem, jak też wzrost kosztów spowodowany oddaniem do eksploatacji nowych obiektów użyteczności publicznej. Rozbudowana infrastruktura społeczna oraz techniczna generuje dodatkowe koszty eksploatacyjne (operacyjne).

Obok finansowych przepływów pionowych w budżecie, zamykających się określonym wynikiem (saldem), występują też przepływy poziome. Te ostatnie polegają na powiązaniu niektórych źródeł dochodów własnych jednostki samorządowej z wydatkiem na konkretne zadanie (cel). Przykładem mogą być wpływy z pobranej opłaty za gospodarowanie odpadami komunalnymi, które powinny bilansować wydatki roczne na cele związane z pokrywaniem kosztów funkcjonowania systemu gospodarowania odpadami komunalnymi ${ }^{15}$. Przepływy poziome charakteryzują się dwoma cechami. Pierwszą jest zapewnienie realności i pewności sfinansowania wydatku budżetowego. Drugą cechą jest wprowadzenie nieelastyczności (sztywności) w przeznaczaniu środków budżetowych na zadania, w których występuje niedobór funduszy. Patrząc ekonomicznie, stan ten należy ocenić krytycznie, bowiem ograniczony zostaje w ten sposób dostęp do narzędzi zarządzania finansami. Przepływy poziome osłabiają motywację do oszczędnego wykorzystania ograniczonych zasobów finansowych.

Ostatnimi elementami budżetu samorządu są przychody i rozchody, utożsamiane $\mathrm{z}$ występowaniem zadłużenia i finansowaniem deficytu. Równowaga budżetowa oznacza stan budżetu, w którym jego wydatki znajdują pokrycie w dochodach. W praktyce równowaga taka nie występuje prawie nigdy, stąd jest bardziej zbliżona do teoretycznej. Nierównowaga między dochodami i wydatkami budżetu występuje wówczas, gdy jest deficyt lub nadwyżka. Deficyt jest wyrazem dysfunkcji budżetu, zaś nadwyżka jego walorem. Znaczenie równowagi budżetu należy rozpatrywać dopiero po uwzględnieniu:

- rodzaju odchyleń od stanu równowagi,

- skali odchyleń od stanu równowagi,

- kierunku ewolucji niezrównoważonego budżetu, czyli ustalenie czy zbliża się on czy oddala od stanu równowagi.

14 M. Wojciechowski, Koszt władzy w polskim samorządzie terytorialnym, Wydawnictwo Difin, Warszawa 2014, s. 127.

15 Art. 6h i 6r ustawy z dnia 13 września 1996 r. o utrzymaniu czystości i porządku w gminach (tekst jednolity: Dz. U. z 2020 r., poz. 1439). 
W obliczu ograniczonych środków budżetowych i złej sytuacji finansowej wielu jednostek samorządowych oraz wciąż dużych potrzeb inwestycyjnych (wynikających przede wszystkim z opóźnień rozwojowych, złym stanem technicznym istniejącej infrastruktury komunalnej - często w znacznym stopniu zdegradowanej), bardzo ważnym elementem gospodarki finansowej jest racjonalizacja wydatków. W istocie chodzi o szczegółowe kryteria, które można zastosować, w tym kryteria efektywnościowe. Jedną z metod kształtowania wydatków publicznych w budżecie jest metoda tzw. historyczna. Polega na tym, że wydatki publiczne w danym cyklu budżetowym są zdeterminowane poziomem i strukturą wydatków publicznych w okresach poprzednich. Metoda ma wiele zalet i w praktyce częste zastosowanie, niemniej posiada również wady. Jedną z nich jest możliwość ukrycia rezerw środków finansowych. Inną metodą wydatkowania środków publicznych jest przyjęcie obiektywnych kryteriów do szacowania poszczególnych wydatków. Kryteriami tymi mogą być przykładowo:

- liczba ludności i jej struktura (według płci, wieku, wykształcenia, miejsca zamieszkania),

- gęstość zaludnienia (koncentracja ludności),

- stan środowiska naturalnego, wyrażający się w parametrach czystości powietrza, wód, jakości gleby, ukształtowania terenu i klimatu,

- stan infrastruktury gospodarczej i społecznej (sieć dróg, liczba mieszkań, szkół, szpitali),

- stan rozwoju gospodarczego, wyrażający się w poziomie i zmianach produkcji, usługach, stopie bezrobocia.

W wydatkach publicznych na wytwarzanie określonych usług (edukacja, ochrona zdrowia, kultura) ma zastosowanie metoda kształtowania wydatków na podstawie potrzeb społecznych. Jej odmianą jest metoda popytowa, która może pozostawać w kolizji z istniejącą bazą wytwarzanych usług. W związku z tym jako sposób kształtowania wydatków publicznych można zastosować metodę podażową, polegającą na tym, że środki publiczne mogą być alokowane, zgodnie $\mathrm{z}$ istniejącą bazą materialną i kadrową. Narzędziem racjonalizacji wydatków publicznych są też kontrakty zawierane między dysponentami środków publicznych a podmiotami wytwarzającymi dobra publiczne ${ }^{16}$. Zastosować można również metodę ekspercką, kiedy specjaliści z różnych dziedzin szacują koszty na podstawie swojej wiedzy oraz stanu danej infrastruktury w kraju i w samorządach.

Metoda przyrostowa jest najczęściej stosowaną w praktyce metodą budżetowania, która polega na wykorzystaniu danych historycznych. Punktem wyjścia są wartości zaewidencjonowane w sprawozdawczości budżetowej w ubiegłych okresach, które następnie koryguje się o odchylenia, powstające w trakcie realizacji budżetu oraz ponowne korygowanie wynikające z przyjętych wskaźników makroekonomicznych (np. inflacja, wzrost wynagrodzeń, zmiany kursów

16 Ustawa z dnia 29 stycznia 2004 r. Prawo zamówień publicznych (tekst jednolity: Dz. U. z 2019 r., poz. 1843 ze zm.). 
walut, zmiana wysokości najniższego wynagrodzenia $)^{17}$. Metoda jest efektywna, tylko w przypadku stabilnych podmiotów, które działają przez cały czas w tym samym otoczeniu. Metoda przyrostowa jest metodą „najszybszą” i najprostszą w opracowaniu budżetu, gdyż dotyczy jedynie wykorzystania danych budżetu z poprzedniego okresu i skorygowania ich poprzez niektóre wielkości ekonomiczne. Posiada ona jednak kilka poważnych wad, a mianowicie: powtarzanie błędów z okresów poprzednich, zbyt duży wpływ układów i powiązań personalnych występujących wśród osób odpowiedzialnych za tworzenie budżetów, marnotrawstwo ograniczonych zasobów finansowych. Według A. Wildavsky’ego klasyczny proces tworzenia budżetu tą metodą ma charakter rutynowy i prowadzi do odwzorowania przeszłej struktury wydatków ${ }^{18}$.

Metoda budżetowania „od zera” polega na szacowaniu wielkości budżetowych dla okresu przyszłego zakładając, że procesy i programy realizowane przez podmiot rozpoczynają się po raz pierwszy. Proces budżetowania „od zera” składa się po pierwsze, $\mathrm{z}$ tworzenia pakietów decyzyjnych uwzględniających charakter ośrodka odpowiedzialności i jego cele. Następnym krokiem jest ocena pakietów wyjściowych i tworzenie pakietów alternatywnych. Po trzecie, uszeregowanie ich według stopnia ważności na podstawie analizy kosztów i korzyści, w ramach danego obszaru działania oraz całości. Ostatnim etapem jest rozdysponowanie zasobów w sposób odpowiadający priorytetom. Metoda „od zera” w odróżnieniu od metody „przyrostowej”: odrzuca dane historyczne, systematycznie porównuje istniejące działania $\mathrm{z}$ alternatywnymi możliwościami zaangażowania zasobów, precyzuje konsekwencje decyzji poszczególnych działań, wykorzystuje warianty planowe, powinna mieć zastosowanie $\mathrm{w}$ dynamicznie rozwijających się podmiotach. Metoda budżetowania „od zera” jest metodą najbardziej odpowiednią dla dużych podmiotów (organizacji), które wymagają szybkiego i ciągłego dostosowywania się do zmieniających się warunków zewnętrznych i wewnętrznych.

17 M. Dylewski, Planowanie budżetowe w podsektorze samorzadowym. Uwarunkowania, procesy, modele, Wydawnictwo Difin, Warszawa 2007, s. 156.

18 Za P. Swianiewiczem, Finanse samorządowe. Koncepcja, realizacja, polityki lokalne, Wydawnictwo Municipium, Warszawa 2011, s. 267. 


\section{Rozdział VII}

\section{Kwestia samodzielności finansowej}

Ramy samodzielności finansowej samorządu (jak wcześniej zaznaczono) określone są w Konstytucji RP oraz w EKSL. W zapisie art. 167 Konstytucji RP postanowiono zapewnić jednostkom samorządu terytorialnego udział $\mathrm{w}$ dochodach budżetowych, adekwatnie do przypadających im zadan publicznych oraz że: zmiany w zakresie zadań $i$ kompetencji jednostek samorzadu terytorialnego następuja wraz $z$ odpowiednimi zmianami $w$ podziale dochodów publicznych. $\mathrm{Z}$ kolei, $\mathrm{w}$ art. 9 ust. 1 EKSL stwierdzono, że społeczności lokalne mają prawo do posiadania własnych zasobów finansowych, niezbędnych do wykonywania uprawnień, i decydują samodzielnie o przeznaczeniu tych zasobów. Kolejny zapis mówi, że wysokość zasobów finansowych społeczności lokalnych powinna być dostosowana do zakresu uprawnień przyznanych im przez Konstytucję $R P$ lub ustawę. W literaturze specjalistycznej uważa się, że zasada samodzielności leży u podstaw decentralizacji władzy publicznej. Słusznie stwierdza A. Babczuk, że bez samodzielności finansowej, wszelkie inne formy samodzielności mają charakter iluzoryczny ${ }^{1}$.

Pomiędzy administracją rządową a administracją samorządową występują finansowe zależności. Budżet państwa zasila bowiem budżety jednostek samorządowych dwoma podstawowymi kanałami finansowymi: subwencją ogólną i dotacjami celowymi. Źródła te mają charakter komplementarny w finansowaniu działalności samorządu terytorialnego (obok dochodów własnych). Podkreślenia wymaga, że podstawowym źródłem finansowania działalności samorządu są dochody własne, a transfery z budżetu państwa powinny jedynie wspierać tę działalność. $Z$ takiego wniosku wynika sugestia i zarazem konsekwencja, iż dochody własne powinny być dominującą grupą w budżetach jednostek samorządowych. Pośrednim dowodem na to jest samodzielność finansowa samorządu, w ujęciu dochodowym. Samodzielność finansowa wywodzi się z podmiotowości prawno-gospodarczej jednostki samorządu, zapewniającej duży zakres samodzielności decyzyjnej. Zdaniem

1 A. Babczuk, Samodzielność finansowa jednostek samorzqdu terytorialnego. Pożadane kierunki zmian w świetle badań ankietowych, [w:] Finanse 2009 - Teoria i praktyka. Finanse publiczne II, Zeszyty Naukowe Uniwersytetu Szczecińskiego nr 547, Szczecin 2009, s. 173. 
K. Piotrowskiej-Marczak, samodzielność finansowa nie oznacza samowystarczalności finansowej, bowiem jednostki samorządowe na całym świecie nie są w stanie pozyskać takich dochodów, które równoważyłyby wydatki².

W literaturze przedmiotu za jedną z podstawowych miar w ocenie samodzielności finansowej samorządu przyjmuje się udział dochodów własnych w dochodach ogółem ${ }^{3}$. Interpretacja ekonomiczna tej sytuacji jest prosta, im wyższy udział tego wskaźnika, tym większa samodzielność finansowa (dochodowa) samorządu. M. Kosek-Wojnar i K. Surówka wskazują jednak, że wskaźniki finansowe mogą dać tylko przybliżony obraz stopnia samodzielności samorządów, choć zarazem podkreślają, iż dochody własne są istotną cechą samofinansowania i dochodowej samodzielności finansowej ${ }^{4}$. Opisywane zjawisko zasilania ogólnego gospodarki samorządu pokazuje wyraźnie rozwiązanie ustrojowe zorientowane na centralizację gospodarki finansowej w Polsce. W gminach, ponad połowa dochodów budżetowych pochodzi z transferów zewnętrznych (tabela 4 i $5 \mathrm{w}$ załączniku), przy czym najlepiej sytuacja przedstawia się w miastach na prawach powiatu oraz w niektórych nielicznych, zamożnych gminach (60-67\%). W pozostałych jednostkach samorządu, głównym źródłem zasilania budżetu samorządów jest budżet państwa (przede wszystkim w powiatach, udział dochodów własnych stanowił maksymalnie 36\% w 2018 r.). W 2019 r. udział dochodów własnych nieznacznie zmniejszył się we wszystkich samorządach, z wyjątkiem powiatów (ok. 40\%). Sytuacja ta ilustruje „rozerwanie” $\mathrm{w}$ mechanizmie finansowania gospodarki samorządowej, polegające na wprowadzeniu w system, dominującego finansowania budżetu państwa. Dezintegracji uległ bowiem naturalny mechanizm uzależniający wydatki budżetu samorządów od wpływów pochodzących z własnej działalności gospodarczej. $\mathrm{W}$ takim układzie środki zewnętrzne $\mathrm{z}$ budżetu państwa spełniają rolę uzupełniającą i pomocniczą, a nie wiodącą ${ }^{5}$. Gospodarka finansowa samorządów jest wtedy bardziej czytelna, jak też spoista, pozbawiona uznaniowości i często przypadkowości oraz wpływu czynnika polityczno-partyjnego.

Wyrazem podmiotowości samorządu w sferze zarządzania finansami jest zatem posiadanie możliwie jak największej samodzielności finansowej. Istota tej samodzielności polega na zdolności do nieskrępowanego kształtowania wielkości i struktury dochodów budżetowych (samodzielność dochodowa), ale także swobodnego wydatkowania środków z budżetu (samodzielność wydatkowa).

2 K. Piotrowska-Marczak, Finanse lokalne w Polsce, Wydawnictwo Naukowe PWN, Warszawa 1997, s. 48.

3 Inna miarą oceny samodzielności finansowej samorządu terytorialnego jest możliwość kształtowania źródeł dochodów własnych (w ramach tzw. władztwa podatkowego).

4 M. Kosek-Wojnar, K. Surówka, Podstawy finansów samorzq̨du terytorialnego, Wydawnictwo Naukowe PWN, Warszawa 2007, s. 87-89.

5 Naturalny mechanizm uzależniający wydatki budżetów lokalnych na obsługę i inwestycje od wpływów pochodzących z realizacji funkcji miastotwórczych istniał w Polsce międzywojennej; por. A. Ginsbert-Gebert, Polityka komunalna, Państwowe Wydawnictwo Ekonomiczne, Warszawa 1984, s. 104. 
Samodzielność finansowa musi charakteryzować się swobodą podejmowania decyzji finansowych, odniesionych zarówno do pozyskiwania dochodów, jak i przeznaczenia ich na różne rodzaje wydatków. Zaprzeczeniem tego jest mechanizm udzielania dotacji celowych, uważanych za narzędzie ograniczające samodzielność. Dotacje wymagają wyznaczania kierunków wydatków oraz nadzoru nad sposobem ich wykorzystania ${ }^{6}$. Z chwilą wstąpienia Polski do Unii Europejskiej, udział dotacji celowych $\mathrm{w}$ budżetach samorządu stopniowo wrastał osiągając poziom od 6 do 10\% dochodów ogółem. Biorąc pod uwagę korzyści ekonomiczne, środki unijne stały się narzędziem aktywizacji działalności inwestycyjnej w polskich samorządach.

Jak uprzednio zaznaczono, do grupy dochodów własnych, warunkujących dochodową samodzielność finansową jednostek samorządowych zalicza się: dochody z podatków lokalnych, dochody z opłat, dochody z posiadanego mienia (majątku), inne dochody, np. wpływy z samoopodatkowania się mieszkańców, spadki, zapisy, darowizny. Budżety samorządów zasilane są wpływami z tytułów wymienionych w ustawie o dochodach jednostek samorzadu terytorialnego ${ }^{7}$. Z uwagi, że podatki i opłaty lokalne stanowią źródło dochodów samorządowych, to władze lokalne uzyskały od ustawodawcy określone władztwo podatkowe. Polega ono na tym, że władze określają wysokość stawek podatków i opłat lokalnych. Mogą też stosować ulgi i zwolnienia, a także umarzać należności, czy rozkładać je na raty. Stawki maksymalne są jednak ustalane odgórnie (centralnie) i są jednolite na terenie kraju8 ${ }^{8}$. Niestety władze lokalne pozbawione są kompetencji do władczego kształtowania elementów podatków, stanowiących źródło dochodów własnych: podatek dochodowy od osób fizycznych opłacany w formie karty podatkowej, podatek od spadków i darowizn oraz podatek od czynności cywilnoprawnych. Mimo że wpływy z tych tytułów zasilają budżety gmin, to władze lokalne nie decydują o żadnym elemencie ich konstrukcji, nie są uprawnione do wprowadzania ulg i zwolnień. Oznacza to brak władztwa podatkowego, choć są to źródła zaliczane do podatkowych dochodów gmin. Tylko wpływy z podatków: od nieruchomości, rolny, leśny i od środków transportowych trafiają bezpośrednio do budżetów poszczególnych gmin?.

W praktyce zakres stawek oraz różnych zwolnień stosowanych przez poszczególne samorządy jest szeroki. Wprawdzie zasady określone w przepisach ustawy o finansach publicznych narzucają maksymalizację dochodów bieżących, to jednak władze lokalne mają ograniczone możliwości w realnym kształtowaniu

6 H. Sochacka-Krysiak (red.), Gospodarka finansowa jednostek terytorialnego w warunkach decentralizacji zarządzania sektorem publicznym, Szkoła Główna Handlowa w Warszawie, Warszawa 2008, s. 42.

7 Art. 4-8 ustawy z dnia 13 listopada 2003 r. o dochodach jednostek samorzadu terytorialnego...

8 K. Surówka, Samodzielność finansowa samorzq̨du terytorialnego w Polsce, Polskie Wydawnictwo Ekonomiczne, Warszawa 2013, s. 62.

9 Pozostałe wymienione podatki pobierane są przez urzędy skarbowe i dopiero za ich pośrednictwem odprowadzane są do budżetu właściwej gminy. 
tych dochodów. Jak wcześniej zaznaczono, w ustalaniu wysokości podatków i opłat lokalnych obowiązują stawki maksymalne w danym roku podatkowym, których gminy nie mogą przekroczyć. Ustawodawca w regulacjach prawnych określił kompetencje w systemie podatkowym. Wskazał, że górne (maksymalne) poziomy ustala minister finansów lub prezes Głównego Urzędu Statystycznego. Stąd minister finansów corocznym obwieszczeniem określa wysokość stawek maksymalnych podatków (od nieruchomości, od środków transportowych) i opłat lokalnych (targowej, miejscowej, uzdrowiskowej, od posiadania psów oraz reklamowej). Konkretne stawki (poniżej maksymalnych poziomów) ustalają władze gminy, kierując się różnymi przesłankami. Do najważniejszych należy zaliczyć: poziomy w porównywalnych gminach, efektywność i koszt pozyskania oraz poczucie równości w odniesieniu do wszystkich podmiotów objętych obowiązkiem podatkowym. Nadto, wiele gmin bierze pod uwagę dotychczasowy poziom stawki podatkowej i jego odległość do stawki maksymalnej. Jeżeli obecna stawka odbiega znacząco w dół od maksymalnego pułapu, to istnieje duża rezerwa na dokonanie ewentualnego manewru podniesienia danej stawki podatkowej.

Polityka podatkowa gmin wpływa na wysokość dochodów własnych. Dlatego dla zapewnienia samodzielności decyzyjnej w stanowieniu wysokości podatków, zdaniem autorki, nie należy dążyć do ograniczania pola uprawnień władz gminnych. Zakres władztwa podatkowego ma szczególne znaczenie w samodzielności dochodowej gmin. Odpowiednio wysoki poziom dochodów własnych w większym stopniu usamodzielnia te jednostki. Największy zakres władztwa podatkowego gmin dotyczy podatku od nieruchomości. Duże efekty zmniejszania obciążeń podatkowych pochodzą właśnie $\mathrm{z}$ tego podatku. Jak wynika $\mathrm{z}$ badań R. Przygodzkiej, stosowanie przez gminy władztwa podatkowego skutkuje utratą części ich dochodów ${ }^{10}$. Władze gmin wiejskich chętnie korzystają z przysługującego im władztwa podatkowego, ustalając stawki podatku od nieruchomości na niższym poziomie od maksymalnego, jak też stosują w różnym zakresie ulgi i zwolnienia. Tym samym władze mniejszych gmin nie traktują tego podatku jako źródła maksymalnej wydajności. Tłumaczyć to można polityką przyciągania potencjalnych mieszkańców i inwestorów. Należy pamiętać, że wzrost podatków daje wzrost dochodów w budżecie, ale powoduje zakłócenia $\mathrm{w}$ alokacji zasobów i prowadzi do obniżenia efektywności ${ }^{11}$.

Analizę samodzielności dochodowej należy rozszerzyć o badanie wszystkich wpływów podatkowych. Wobec tego dochody własne (sensu stricto) powiększane są o udział w podatkach CIT i PIT oraz wielkość subwencji ogólnej, finansującej ważne zadania publiczne. Dopiero taka wielkość w dochodach ogółem pozwala określić pole swobody decydowania w sferze finansowej samorządu. W istocie

10 R. Przygodzka, Władztwo podatkowe a stabilność finansowa gmin, „Nierówności Społeczne a Wzrost Gospodarczy" 2014, nr 4, s. 340-341.

11 D. Begg, S. Fisher, R. Dornbush, Ekonomia, t. 1, Państwowe Wydawnictwo Ekonomiczne, Warszawa 1995, s. 481. 
obserwowanie kształtowania się bezwzględnych wielkości finansowych, dotyczących dochodów jednostek samorządu pozwala ocenić ich potencjał finansowy (tabela 4 w załączniku). W badanym horyzoncie czasowym, od 1999 r. występuje ciągły wzrost dochodów ogółem, jak też dochodów pochodzących z poszczególnych źródeł wymienionych w Konstytucji $R P$.

Struktura dochodów budżetowych jednostek samorządu terytorialnego (przedstawiona $\mathrm{w}$ tabeli $5 \mathrm{w}$ załączniku) obrazuje ważność poszczególnych źródeł tworzących dochody. W świetle podstawowych źródeł można ocenić zakres samodzielności finansowej jednostek samorządowych i uzależnienie od budżetu państwa. Zgromadzone dane wskazują na umiarkowany udział dochodów własnych. W większości przekrojów samorządowych, udział dochodów własnych kształtuje się poniżej udziału dochodów pochodzących z transferów zewnętrznych. Jedynie w miastach na prawach powiatu i w samorządzie województwa ich udział przekracza 50\% ogółu dochodów, co świadczy o największej samodzielności finansowej. W najgorszej sytuacji są powiaty, których dochody własne stanowią słabą podstawę świadczenia usług publicznych, mimo tendencji wzrostowej od $2011 \mathrm{r}$. Na szczególną uwagę zasługuje proporcja subwencji ogólnej do dotacji celowych. Od 2017 r. obserwuje się przewagę dotacji nad subwencją, z wyjątkiem powiatów, gdzie od początku dominowały dochody z tytułu subwencji. Można to tłumaczyć dużymi wydatkami powiatów na sferę edukacji i utrzymania placówek szpitalnych. Przewaga w ostatnich latach zasilania dotacyjnego budżetów samorządu, destabilizuje finanse lokalne, ponieważ dotacje mają charakter uznaniowy. Dotacje mogą być też niewykorzystane (z różnych przyczyn), jak też przeznaczone na finansowanie bądź dofinansowanie zadań własnych samorządu.

Zagrożeniem dla samodzielności finansowej samorządu jest wzrost udziału dotacji celowych $\mathrm{w}$ dochodach budżetowych jednostki. W świetle zapisów ustawy o dochodach jednostek samorzadu terytorialnego, dotacje celowe przekazywane są m.in. z budżetu państwa na realizację zadań zleconych z zakresu administracji rządowej, ale także na finansowanie lub dofinansowanie zadań własnych. Zdaniem B. Guziejewskiej, jeśli wielkość dotacji jest wysoka, to system dotowania zaczyna przeważać w polityce budżetowej samorządu i zarazem występuje niechęć do samodzielnych działań, inicjatyw oraz dbania o dochody własne ${ }^{12}$. W przypadku zadań własnych zasilanie budżetów samorządowych powinno być zastąpione innym rozwiązaniem (np. wzrost udziału w podatkach dochodowych). Ułomnością funkcjonującego mechanizmu zasilania budżetów jest m.in. niestabilność i dowolność przyznawania dotacji poszczególnym jednostkom samorządowym (czyli uznaniowość) ${ }^{13}$. Zatem finansowanie zadań własnych samorządu nie powinno być uzależnione od transferów $\mathrm{z}$ budżetu państwa - wyjątek może stanowić subwencja ogólna, której konstrukcja (mimo że też krytykowana) wyklucza

12 B. Guziejewska, Zewnętrzne źródła finansowania samorzq̨du terytorialnego. Teoria i praktyka, Wydawnictwo Uniwersytetu Łódzkiego, Łódź 2008, s. 101.

13 L. Patrzałek, Finanse samorzq̨du terytorialnego, Wydawnictwo Uniwersytetu Ekonomicznego we Wrocławiu, Wrocław 2010, s. 271. 
uznaniowość. Nadto, jak już wspomniano, dotacja z uwagi na fakt, iż musi być wydatkowana na dany cel, powoduje, że niewykorzystane środki finansowe - wypracowane jako oszczędności na zadaniu, muszą być zwrócone podmiotowi dotującemu (w omawianym przypadku do budżetu państwa).

Z kolei, gdy mamy do czynienia z subwencją, sytuacja jest inna, bowiem niewykorzystana kwota środków - nawet z części oświatowej, może być wydatkowana na inne cele. Subwencjonowanie zapewnia większą elastyczność organów samorządu w racjonalnym gospodarowaniu środkami pochodzącymi z budżetu państwa. W Niemczech dotacje celowe uważane są jako zagrożenie dla samorządności gmin, ponieważ pozwalają na dużą ingerencję w działalność komunalną (ich udział kształtuje się na poziomie ok. 25\% dochodów budżetu). Tamtejsze gminy otrzymują dotacje celowe pod warunkiem brania udziału w wydatkach inwestycyjnych. Gminy są później obciążane kosztami utrzymania zrealizowanych inwestycji ${ }^{14}$.

Znaczny wzrost udziału dotacji w budżetach gmin od 2017 r. odzwierciedla zjawisko, że władze samorządu gminnego zajmują się w dużym stopniu administrowaniem, zamiast decydowaniem o rozwoju jednostki ${ }^{15}$. Ma to miejsce wtedy, gdy znaczna część dochodów samorządowych ma ściśle określone przeznaczenie (np. dotacje celowe, środki pochodzące z opłat za gospodarowanie odpadami komunalnymi ${ }^{16}$, czy z opłat za zezwolenia na sprzedaż napojów alkoholowych - tzw. fundusz korkowy ${ }^{17}$ ). Takie ukierunkowanie dochodów na finansowanie wyłącznie konkretnych zadań, nie tylko ogranicza zakres samodzielności finansowej władz samorządu, ale również nie przyczynia się do racjonalnej gospodarki finansowej, gdyż wygospodarowane oszczędności na tych zadaniach można byłoby zagospodarować tam, gdzie występuje niedobór środków i pilna potrzeba podjęcia działań. $\mathrm{W}$ przeciwnym razie, zawęża to pole manewru środkami finansowymi, zmniejszając sprawność działania władz samorządowych. Należy zgodzić się z K. Surówką i K. Owsiak, że „władztwo finansowe samorzadu terytorialnego zarówno po stronie dochodowej, jak $i$ wydatkowej, będące atrybutem jego samodzielności finansowej, ograniczone jest do dysponowania środkami finansowymi pochodzącymi

14 E. Olejniczak-Szałowska, Samorząd terytorialny w Europie Zachodniej, [w:] Samorząd terytorialny. Podstawowe zagadnienia, (red.) M. Stahl, E. Olejniczak-Szałowska, Fundacja Rozwoju Demokracji Lokalnej, Warszawa 1994, s. 64.

15 Trzeba zaznaczyć, że wzrost dotacji celowych od 2016 r. związany jest m.in. z realizacją Programu Rodzina $500+$.

16 Zgodnie z art. 6r ust. 1aa ustawy z dnia 13 września 1996 r. o utrzymaniu czystości i porzq̨dku w gminach (tekst jednolity: Dz. U. z 2020 r., poz. 1439), środki pochodzące z opłat za gospodarowanie odpadami komunalnymi nie mogą być przez gminę wykorzystywane na cele niezwiązane z pokrywaniem kosztów funkcjonowania tego systemu.

17 Zgodnie z art. $18^{2}$ ustawy z dnia 26 października 1982 r. o wychowaniu w trzeźwości i przeciwdziałaniu alkoholizmowi (tekst jednolity: Dz. U. z 2019 r., poz. 2277 ze zm.), dochody z opłat za zezwolenia na sprzedaż napojów alkoholowych gminy mogą przeznaczać wyłącznie na takie działania, które zostały przewidziane w gminnym programie profilaktyki i rozwiązywania problemów alkoholowych oraz gminnym programie przeciwdziałania narkomanii. 
z okrojenia dochodów pierwotnych, to znaczy środkami, w przeważającym zakresie, niewypracowanymi przez dysponentów tych środków, lecz oddanymi do dyspozycji poprzez repartycję dochodów pochodzacych od sektora prywatnego" ${ }^{18}$.

W samorządzie brakuje też standaryzacji kosztów usług, na podstawie których ustalana byłaby wartość środków transferowych $\mathrm{z}$ budżetu państwa ${ }^{19}$. Analiza strony wydatków budżetu przedstawia obraz kierunków (priorytetów) w polityce gminy. Niektóre z nich są ewidentnie naruszone przez strukturę zadań własnych. Obserwacja struktury wydatków według charakteru działalności (bieżące i majątkowe) pozwala ocenić skłonność gminy do rozwoju. Jego warunkiem jest przeznaczanie odpowiednich wydatków na cele inwestycyjne. W gminach występuje umiarkowana tendencja do inwestowania, gdyż pochłaniają one średnio ok. 20\% środków. Są też gminy, które zdecydowały się na duży wysiłek inwestycyjny (30, a nawet $40 \%$ budżetu). Generalnie badanie strony wydatkowej jest potrzebne do ustalenia związku wydatków z rzeczywistymi korzyściami i eliminacją marnotrawstwa użytych zasobów publicznych. Strategiczne i prorozwojowe myślenie władz publicznych polega na takim podziale budżetu, by zaplanowane wydatki (a w zasadzie ich część) powróciły do budżetu w postaci zwiększonych dochodów własnych. Spora część wydatków (tak jak w budżecie państwa) ma charakter „sztywny”, ponieważ wynika z typu realizowanych zadań, zobowiązań wynikających z ustaw oraz samego oblicza działalności usługowej samorządu (pracochłonny wyraz usług przekłada się na istotną wielkość wydatków bieżących - koszty osobowe).

18 K. Surówka, K. Owsiak, Administrowanie czy rozwój - 20 lat doświadczeń finansowania polskiego samorzq̨du terytorialnego, „Nierówności Społeczne a Wzrost Gospodarczy” 2018, nr 56, s. 26.

19 G. Maśloch, J. Sierak (red.), Gospodarka i finanse samorzqdu terytorialnego, Oficyna Wydawnicza Szkoła Główna Handlowa w Warszawie, Warszawa 2013, s. 185. 



\section{Rozdział VIII}

\section{Utrzymanie majątku komunalnego i jego rozwój}

Przywrócenie w 1990 r. własności komunalnej oraz osobowości prawnej jednostkom samorządowym, stworzyło podstawy gospodarcze do funkcjonowania samorządu terytorialnego w Polsce. Pełnienie przez władze samorządu i służby komunalne roli gospodarczej, w celu zaspokajania zbiorowych potrzeb społecznych ludności, wymaga posiadania majątku. Można powiedzieć, że mienie (majątek) komunalne jest trwałą podstawą samorządności gospodarczej gmin, powiatów i województwa. Jego wykorzystanie współdecyduje o procesie świadczenia usług komunalnych w ramach realizacji zadań publicznych. Główna część tego majątku powstała w wyniku przeprowadzenia procesu komunalizacji mienia państwowego w latach 90. Pierwszymi podmiotami mienia komunalnego stały się gminy, jako podstawowe jednostki samorządu terytorialnego w Polsce. Od 1999 r. w składniki mienia komunalnego zostały wyposażone kolejne jednostki (szczeble) samorządu.

Ustawa o samorządzie gminnym zawiera definicję mienia komunalnego. Zgodnie z zapisami, mieniem komunalnym jest własność i inne prawa majątkowe należące do poszczególnych gmin i ich związków oraz mienie innych gminnych osób prawnych, $w$ tym przedsiębiorst $w^{1}$. Mienie jest majątkowym instrumentem zarządzania, a jego posiadanie warunkiem samodzielności decyzyjnej. Mienie stanowi niejednorodny zasób gospodarczy i obejmuje takie składniki ekonomiczne jak:

- majątek główny (nieruchomości: grunty przeznaczone na cele publiczne o charakterze lokalnym, tj. pod budownictwo komunalne, tereny zieleni publicznej, cmentarze komunalne itp.; budynki mieszkalne i lokalne stanowiące komunalne zasoby mieszkaniowe; obiekty i urządzenia lokalnej infrastruktury społecznej takie jak żłobki, przedszkola, szkoły, placówki służby zdrowia, kultury, obiekty sportowe i rekreacyjne; obiekty i urządzenia lokalnej infrastruktury technicznej, w tym sieć wodociągowa, kanalizacyjna, cieplna i gazowa, obiekty i urządzenia elektroenergetyczne, melioracyjne, ochrony

1 Art. 43 ustawy z dnia 8 marca 1990 r. o samorzadzie gminnym (tekst jednolity: Dz. U. z 2020 r., poz. 713 ze zm.). 
przeciwpożarowej, drogi publiczne; środki ruchome: maszyny, urządzenia, środki transportowe),

- majątek pozostały (przedsiębiorstw oraz innych komunalnych osób prawnych, wartości niematerialne i prawne).

Dominująca część majątku komunalnego obejmuje budynki, budowle i urządzenia tworzące infrastrukturę techniczną i infrastrukturę społeczną. Według tradycyjnego podziału infrastruktura techniczna może być punktowa (źródła i obsługa) i sieciowa. Elementy infrastruktury społecznej są rozproszone i skoncentrowane na obszarach o większej gęstości zaludnienia (szkolnictwo, placówki kultury i rekreacji, ośrodki opieki zdrowotnej). Charakter zagospodarowania przestrzennego i wyposażenie w elementy infrastruktury wpływa na ekonomikę działalności. W samorządzie, przede wszystkim w gminach miejskich, istotną część majątku tworzą komunalne zasoby mieszkaniowe. Niektóre samorządy podjęły duży wysiłek finansowy i zrealizowały obiekty kapitałochłonne o dużych modułach, które nie służą wprost realizacji obligatoryjnych zadań własnych (np. lotniska, parki wodne, stadiony, hale sportowe). Odbyło się to kosztem innych, ważniejszych z punktu widzenia mieszkańca potrzeb, ponieważ zaangażowało to duże nakłady finansowe na realizację inwestycji i nadal angażuje duże środki budżetowe na ich utrzymanie. Bez wątpienia, sytuacja taka wpływa na kondycję finansową i możliwości rozwojowe tych jednostek samorządowych.

Zgodnie $z$ ustawą o samorządzie gminnym, mienie komunalne może być przejęte w sześciu procedurach. Pierwsza określa przejęcie mienia na podstawie ówczesnej ustawy - Przepisy wprowadzajace ustawę o samorzadzie terytorialnym ${ }^{2}$. Był to doniosły akt prawny, ponieważ stwarzał ramy organizacyjne i instytucjonalne dla procesu komunalizacji mienia państwowego. Gmina może otrzymać składniki mienia przez przekazanie jej, w związku z utworzeniem lub zmianą granic gminy. Przekazanie mienia odbywa się wtedy w drodze porozumienia zainteresowanych gmin. Jeśli nie dojdzie do porozumienia, wówczas rozstrzygająca staje się decyzja Prezesa Rady Ministrów. Kolejnym sposobem nabycia mienia komunalnego jest przekazanie go przez administrację rządową na zasadach określonych przez odpowiednie rozporządzenie. Mienie komunalne może być tworzone również dzięki własnej działalności gospodarczej gminy. Nabycie mienia jest również możliwe przez inne czynności prawne oraz w sytuacjach określonych w odrębnych przepisach.

Istotą gospodarowania majątkiem komunalnym jest dbanie o jego racjonalne wykorzystanie oraz skupienie uwagi na jego powiększaniu, odpowiednio do rosnących i zmieniających się potrzeb mieszkańców samorządu. Majątek infrastrukturalny wymaga szczególnej uwagi i dużych nakładów finansowych na utrzymanie go w należytym stanie technicznym oraz funkcjonalnym.

2 Komunalizacja mienia państwowego odbywała się na podstawie ustawy z dnia 10 maja $1990 \mathrm{r}$. Przepisy wprowadzajace ustawę o samorządzie terytorialnym i ustawę o pracownikach samorządowych (Dz. U. z 1990 r. Nr 32, poz. 191 ze zm.). 
Od stanu tego majątku zależy bezpieczeństwo i jakość świadczonych usług publicznych. Biorąc pod uwagę zwiększenie zdolności produkcyjno-usługowych, rezerwę awaryjną i rezerwę na miarę przyszłych potrzeb, zbędna część majątku powinna być sprzedana lub inaczej zagospodarowana. Baczna uwaga powinna być zwrócona na wykorzystanie wolnych terenów w oparciu o prowadzoną politykę rozwoju samorządu. Niektóre z nich mogą być „uzbrojone” w urządzenia techniczne (podnosi to wartość terenu) i stanowić interesującą ofertę dla potencjalnych inwestorów. Możliwy jest również zakup przez samorząd nowych terenów z myślą o ich wykorzystaniu dla określonych celów (np. budowa spalarni odpadów, wniesienie do spółki w ramach partnerstwa).

Przepisy prawa określają wymogi jakimi kierować się powinny organy samorządów w gospodarce majątkiem komunalnym. Gospodarowanie majątkiem określone jest przepisami m.in. takich ustaw jak: o samorządzie gminnym, o samorządzie powiatowym, o samorządzie województwa, o rachunkowości $i^{3}$, o gospodarce komunalnej, o gospodarce nieruchomościami ${ }^{4}$. Obowiązkiem osób uczestniczących w zarządzaniu mieniem komunalnym jest zachowanie szczególnej staranności przy wykonywaniu tzw. zarządu (w tym zwykłego należącego do kompetencji organu wykonawczego), zgodnie z przeznaczeniem tego mienia i jego ochrona. Niespełnienie tego wymogu może skutkować odpowiedzialnością majątkową, dyscyplinarną, karną, polityczną i finansową związaną $\mathrm{z}$ naruszeniem dyscypliny finansów publicznych ${ }^{5}$.

Kierowanie się zasadą racjonalności nakazuje gospodarowanie majątkiem w wielkości i o strukturze niezbędnej dla wykonywania zadań własnych. Natomiast wykonywanie zadań zleconych odbywa się dwojako: przy użyciu majątku należącego do skarbu państwa bądź jednostki samorządowej (np. usługi świadczone przez urzędy stanu cywilnego). Tymczasem, wiele jednostek samorządowych posiada majątek komunalny, który nie jest w pełni wykorzystywany w realizacji zadań publicznych. O zagospodarowaniu zbędnego majątku decydują organy w samorządzie. Jest to ważne zagadnienie, gdyż utrzymanie rezerwy majątku, nieuzasadnionej potrzebami wymaga jego sfinansowania środkami budżetu przy braku uzyskania wymiernej korzyści dla samorządu. Istnieje jeszcze jedna postać wystąpienia nadmiernego majątku komunalnego, czasowo niewykorzystanego, kiedy powstał on w wyniku działalności gospodarczej samorządu (przez zakup, w wyniku realizacji inwestycji, darowizny itd.). Dzieje się tak, ponieważ gminy mogą prowadzić działalność gospodarczą, wykraczającą poza ramy użyteczności publicznej, jeżeli są spełnione prawne warunki. Utrzymywanie takiej rezerwy majątkowej wydaje się być uzasadnione, jeśli będzie wykorzystana ekonomicznie

3 Ustawa z dnia 29 września 1994 r. o rachunkowości (tekst jednolity: Dz. U. z 2021 r., poz. 217).

4 Ustawa z dnia 21 sierpnia 1997 r. o gospodarce nieruchomościami (tekst jednolity: Dz. U. z 2020 r., poz. 1990 ze zm.).

5 K. Wilko, Zasady zarządzania gospodarka komunalnq i mieniem samorzqdu, https://samorząd.infor.pl [dostęp: 07.12.2007]; A. Puszkarska, Zasady zarządzania mieniem komunalnym, „Rzeczpospolita” z 17 lipca 2018 r. 
(stanowi wtedy źródło dochodu w budżecie). Z perspektywy efektywności gospodarki majątkowej na uwagę zasługują trzy przekroje analizy:

- wielkość i struktura majątku komunalnego,

- ocena stanu poszczególnych grup składników majątku,

- ocena rezerw w zdolnościach produkcyjno-usługowych.

Podstawą realizacji zadań publicznych jest wielkość i struktura tego majątku, które powinny być dostosowane do zakresu wykonywanych zadań. Na ogół wielkość posiadanego majątku komunalnego jest duża i stanowi pochodną wielkości samorządu. Miarą cząstkową rozwoju gospodarki samorządowej jest wzrost realnego wskaźnika wartości majątku komunalnego per capita. Majątek komunalny charakteryzuje się zróżnicowaną strukturą, na którą wpływ mają trzy czynniki:

- status administracyjny jednostki samorządowej,

- sposób zagospodarowania terenu,

- wielkość popytu na usługi komunalne.

Gminy wiejskie z reguły odznaczają się odmienną strukturą majątku od pozostałych typów gmin, ze względu na większą indywidualizację obsługi komunalnej. $\mathrm{W}$ tych gminach pewne usługi komunalne (np. zaopatrzenie w wodę i w energię, oczyszczanie ścieków, indywidualny transport) są realizowane przez samych mieszkańców, w ramach gospodarstw domowych (koprodukcja). W większości usług społecznych, mieszkańcy tych jednostek korzystają z usług gmin miejskich. W dużych ośrodkach miejskich (miastach na prawach powiatu) skoncentrowane jest świadczenie usług ogólnogminnych i usług o charakterze ponadgminnym. W związku z tym, wyposażenie infrastrukturalne $\mathrm{w}$ tych ostatnich gminach jest odpowiednio większe i zróżnicowane.

Każda gmina, z uwagi na położenie, tradycje i historię, gospodarkę oraz wyposażenie w zasoby naturalne, posiada odmienne zagospodarowanie swojej przestrzeni. Sposób zagospodarowania stanowi konsekwencję rozmieszczenia (naturalnego lub sztucznego) funkcji gospodarczej i społecznej, a struktura majątku komunalnego jest odbiciem owego zróżnicowania. W poszczególnych rodzajach gmin kształtują się pewne typowe struktury majątku komunalnego. W gminach wiejskich dominujące są składniki związane drogownictwem i oświetleniem, w mniejszym stopniu związane z edukacją, zaopatrzeniem w wodę, oczyszczalnie ścieków, kultura (świetlice, remizy). W gminach miejsko-wiejskich obok drogownictwa i oświetlenia przeważa infrastruktura techniczna i społeczna, skupiona w ośrodkach miejskich. Z kolei, w dużych miastach, oprócz urządzeń infrastruktury technicznej i społecznej, znaczące miejsce zajmują tereny i budowle publiczne (w tym zabytki) oraz komunalna gospodarka mieszkaniowa. Istnieje dodatnia korelacja między skalą jednostki samorządowej a wielkością popytu na usługi komunalne. Dodatkowo, w miarę wzrostu rozmiaru samorządu, rośnie zróżnicowanie w dziedzinie usług publicznych, które w dużych miastach w znacznej części mają charakter wyspecjalizowany. W realizacji zadań publicznych wykraczają one poza obszar obligatoryjnych zadań własnych. Istotny wpływ na kształtowanie się popytu usług mają procesy demograficzne, wskazujące na jednoznaczne tendencje zmian. 
W Europie, w tym w Polsce, występuje proces starzenia się ludności (rośnie udział ludzi w wieku poprodukcyjnym).

Drugą płaszczyzną oceny majątku komunalnego jest jego analiza według poszczególnych grup składników. Instrumentem pozwalającym na to, jest ocena zużycia technicznego oraz moralnego. Grupowanie składników podyktowane jest przepisami prawa, dotyczącego klasyfikacji składników majątku trwałego. W kolejnej płaszczyźnie oceny gospodarki majątkiem istotne znaczenie posiada utrzymanie rezerw produkcyjno-usługowych. Zapewnienie tych rezerw wpływa na obniżenie efektywności ekonomicznej. Dotyczy to przede wszystkim elementów infrastruktury technicznej i infrastruktury społecznej. Jednak utrzymanie rezerw jest konieczne i niezbędne w myśleniu strategicznym.

Nie ma jednego, uniwersalnego modelu gospodarowania majątkiem komunalnym $^{6}$. Należy nim gospodarować racjonalnie, zgodnie $\mathrm{z}$ interesem wspólnoty. Organy samorządowe na podstawie rachunków efektywności powinny formułować cele, do jakich majątek komunalny będzie wykorzystany, a następnie odnieść jego użytkowanie (eksploatację) do planów i potrzeb inwestycyjnych ${ }^{7}$. W gospodarce majątkiem komunalnym istotne są dwa aspekty analizy. Pierwszy, dotyczy stabilności majątkowej w działalności inwestycyjnej w kontekście odtworzenia lub modernizacji istniejących składników mienia (środków trwałych). Drugi aspekt odnosi się również do działalności inwestycyjnej, polegającej na procesie powiększania elementów tego mienia. Jest to zgodne z klasyczną definicją inwestycji, rozumianą jako ponoszenie nakładów gospodarczych w celu odtworzenia i modernizacji lub budowy i rozbudowy środków trwałych. W obydwu przypadkach, mamy do czynienia ze składnikami majątku komunalnego, przy czym odtworzenie lub modernizacja obejmuje istniejący majątek, który wymaga poprawy stanu technicznego. Natomiast budowa i rozbudowa dotyczą powiększenia dotychczasowego majątku. Wartość majątku komunalnego powstałego w ten sposób ulega powiększeniu o nakłady poniesione w działalności inwestycyjnej.

Między działalnością eksploatacyjną i działalnością inwestycyjną samorządu występuje sprzężenie zwrotne. W eksploatacji komponenty majątku komunalnego ulegają naturalnemu zużyciu (technicznemu i moralnemu), który nie obejmuje drobnych napraw, konserwacji. Spadek wartości majątku winien być rekompensowany poniesieniem nowych nakładów inwestycyjnych. Dotyczy to również procesów modernizacji tego majątku, które mogą doprowadzić do zmniejszenia kosztów jednostkowych świadczenia danego typu usług publicznych. Mówiąc ogólnie, użytkowanie majątku komunalnego „wymusza” podejmowanie wysiłku inwestycyjnego. Dodatkowo do wzrostu wielkości i wartości

6 E. Wojciechowski, Samorzad terytorialny w warunkach gospodarki rynkowej, Wydawnictwo Naukowe PWN, Warszawa 1997; M. Wartalska, Wybrane przesłanki budowy programów zarzq̨dzania majątkiem komunalnym w aspekcie gospodarowania finansami miasta, [w:] Konkurencyjność i potencjat rozwoju polskich metropolii - szanse i bariery, „Biuletyn Komitetu Przestrzennego Zagospodarowania Kraju PAN", z. 214, Warszawa 2004.

7 G. Maśloch, J. Sierak, Gospodarka i finanse samorzqdu terytorialnego..., s. 159-160. 
majątku przyczyniają się niezaspokojone potrzeby w wielu branżach gospodarki komunalnej (luki infrastrukturalne) ${ }^{8}$. Przyczynia się do tego też nieracjonalna gospodarka przestrzenią, pociągająca za sobą skutek w postaci rozproszonej i chaotycznej zabudowy . Powoduje to wzrost kosztów funkcjonowania samorządu. Podstawą efektywnej polityki majątkowej jest rejestracja wiedzy o stanie technicznym i ekonomicznym poszczególnych składników mienia oraz o potrzebach społecznych, których zaspokajanie wymaga użycia odpowiednich środków trwałych. Następnym warunkiem polityki majątkowej jest opracowanie zbioru planów długookresowych, dotyczących przedsięwzięć inwestycyjnych oraz zakupów inwestycyjnych $\mathrm{w}$ celu odtworzenia lub powiększenia poszczególnych składników mienia. Takie postępowanie jest niezbędne dla bezpieczeństwa i ciągłości realizacji zadań publicznych, w tym wyeliminowanie poważnych awarii, wymagających znacznie większych nakładów gospodarczych oraz powodujących dotkliwe utrudnienia dla użytkowników samorządu.

Widoczną dysfunkcją w gospodarowaniu majątkiem jest nieprofesjonalny i mało skuteczny nadzór oraz kontrola nad stanem majątku, jak też jego właściwym wykorzystaniem. Poszczególne podmioty mienia komunalnego na ogół samodzielnie decydują o przeznaczeniu i sposobie wykorzystania składników majątkowych. Jednak ułomnością polityki majątkowej jest brak rzetelnej diagnozy i koordynacji działań tych podmiotów. Poruszane zagadnienie odnosi się bardziej do średnich i dużych jednostek samorządowych, w których działalność prowadzą liczne podmioty mienia komunalnego oraz istnieje mała transparentność procesów decyzyjnych. W dużych miastach, występują sytuacje, gdy niektóre składniki majątku są zbędne lub nieracjonalnie wykorzystywane. Nieużytkowanie ich przyczynia się do niszczenia (degradacji) zasobów majątkowych, co należy uznać za niegospodarność. Celowe (odpowiednie) zagospodarowanie wszystkich składników majątku wiąże się ze spójną polityką majątkową, która powinna być częścią polityki społeczno-gospodarczej władzy samorządowej. Narzędziem tej polityki są plany, programy lub strategie rozwoju. M. Łyszkiewicz zweryfikowała hipotezę o słabości gospodarowania mieniem komunalnym, spowodowaną niewykorzystaniem instrumentów zarządzania oraz brakiem zorganizowanego systemu gospodarowania mieniem komunalnym ${ }^{10}$. W polskim samorządzie brak jest strategii w zakresie gospodarki majątkowej oraz skutecznego systemu sprawowania nadzoru i kontroli nad gospodarką majątkową.

Polityka majątkowa jest szczególnie istotna dla gospodarki finansowej samorządu. Zaniedbania (liczne awarie), zaniechania (brak bezpieczeństwa, nawet katastrofy) w zarządzaniu majątkiem komunalnym wpływają na wzrost kosztów

8 J. Sierak, Komunalna luka infrastrukturalna a możliwości budżetowe gmin w jej ograniczaniu, Oficyna Wydawnicza SGH, Szkoła Główna Handlowa, Warszawa 2019, s. 418-425.

9 T. Markowski, Budowanie regulacyjnego systemu planowania przestrzennego. Teoria sprawiedliwości podstawa budowy systemu, [w:] Przestrzeń dobrem publicznym - potrzeba nowych rozwiq̨zań w gospodarowaniu przestrzeniq, Najwyższa Izba Kontroli, Warszawa 2016, s. 25.

10 M. Łyszkiewicz, Gospodarowanie majatkiem komunalnym. Zasady, metody, strategie, Wydawnictwo CeDeWu, Warszawa 2016, s. 303. 
funkcjonowania i rozwoju jednostki samorządowej oraz na stan jej finansów. Ilustracją tego wpływu mogą być wyższe podatki i opłaty lokalne, wyprzedaż nieruchomości, terenów komunalnych, wzrost zadłużenia, a w ostatecznym rozrachunku obniżenie jakości świadczonych usług publicznych ${ }^{11}$. Gospodarka majątkiem, w tym o dużej wartości, jest kluczową dziedziną działalności samorządu. Tak jak w przedsiębiorstwie, również $\mathrm{w}$ samorządzie, gospodarowanie majątkiem należy do istotnych funkcji jego organów, szczególnie wykonawczych. Posiadanie majątku jest probierzem wypełniania faktycznej roli ekonomicznej. Problematyka majątkowa w samorządzie jest niedoceniana $\mathrm{w}$ stosunku do roli jaką pełni $w$ funkcjonowaniu i rozwoju gospodarki komunalnej ${ }^{12}$. Nie jest ona „W bliskim” kontakcie z interesami mieszkańców, gdyż znajduje się na dalszym planie działalności struktur samorządowych i jest ukryta w "gąszczu” spraw prawnych, organizacyjnych i technicznych. Waga gospodarki majątkiem dostrzegana jest $\mathrm{w}$ sytuacjach szczególnych, np. gdy dokonywana jest negatywna ocena jakości świadczonych usług lub jeśli wystąpią dokuczliwe awarie urządzeń infrastruktury o dalekosiężnych konsekwencjach. Zainteresowanie gospodarką majątkiem w samorządzie jest rozproszone, nierównoważne, jakby odsunięte na margines głównego nurtu uwagi, związanego z procesem świadczenia usług i podejmowaniem spektakularnych zamierzeń inwestycyjnych.

Organy stanowiące rzadko zajmują się gospodarką majątkową, pozostawiając ją organowi wykonawczemu (co zresztą leży w jego kompetencji). Rady są aktywne okazjonalnie, kiedy chodzi o podejmowanie decyzji organizacyjnych w zakresie majątku komunalnego. Są jednak powściągliwe w badaniu efektywności wykorzystania składników majątkowych w jednostkach organizacyjnych samorządu, nie mówiąc o istotnej kontroli, do której mają prawo. Wyjątkiem są same jednostki organizacyjne, które dzięki analizie i ocenie wykorzystanego majątku, posiadają wiedzę o wielkości, strukturze, zużyciu i potrzebach dotyczących poszczególnych elementów. W jednostkach i zakładach budżetowych, gospodarowanie majątkiem odbywa się przy udziale komórek organizacyjnych urzę$\mathrm{du}$, ponieważ podmioty te nie posiadają osobowości prawnej. Jedynie w części, w spółkach komunalnych gospodarka majątkiem stanowi integralną dziedzinę działalności przedsiębiorstwa jako całości ${ }^{13}$. Ograniczony zakres informacji o go-

11 Wyprzedaż niektórych składników majątkowych (głównie nieruchomości) odbywa się pod presją niedoboru środków finansowych, groźbą utraty płynności finansowej. Czym innym jest sprzedaż majątku polegająca na jego zmniejszeniu (dywestycje) m.in. z powodu nieprzydatności dla prowadzonej działalności.

12 W ustawie o samorządzie gminnym, tematyce mienia komunalnego poświęcono zaledwie siedem artykułów. Niemniej poszczególne rodzaje składników mienia i gospodarka nimi znajdują wyraz w innych regulacjach prawnych (np. mieszkania komunalne w ustawie $z$ dnia 21 czerwca 2001 r. o ochronie praw lokatorów, mieszkaniowym zasobie gminy i o zmianie Kodeksu cywilnego, tekst jednolity: Dz. U. z 2020 r., poz. 611 ze zm.).

13 W sytuacjach, kiedy spółka komunalna pełni rolę operatora usług wykorzystującego jedynie majątek samorządu, pozostałe decyzje w gospodarce majątkowej podejmowane są przez organ wykonawczy i administrację. 
spodarce majątkowej daje zawężone podstawy merytoryczne dla przeprowadzenia oceny. Wynika to z przepisów prawa, które w niewielkim stopniu i niedbale regulują istotne kwestie, które należy rozstrzygnąć w procesie wykorzystania tego majątku. Ustawa o finansach publicznych oraz tzw. ustawy ustrojowe, jedynie częściowo mówią o zasadach i metodach gospodarowania majątkiem komunalnym.

W gospodarowaniu mieniem komunalnym ważne są dwa punkty widzenia. Pierwszy, społeczny traktuje majątek jako środek w realizacji zadań własnych. Nie jest możliwe dostarczenie usługi komunalnej, bez użycia określonych i potrzebnych składników majątku. Nawet w świadczeniu usług wysoce pracochłonnych (obsługa administracyjna), konieczne jest wykorzystanie budynków i sprzętu służącego wymianie informacji. Wielkość majątku komunalnego stanowi ogólnie pochodną z zakresu realizowanych zadań. W praktyce mogą wystąpić trzy sytuacje majątkowe w zależności od stopnia jego wykorzystania. W pierwszej, jego wielkość jest wystarczająca w stosunku do potrzeb usługowych, w drugiej - występuje niedobór majątku, w trzeciej - istnieje jego nadmiar. Są to typowe przypadki w działalności każdego przedsiębiorstwa, determinujące wybór strategii inwestycyjnej oraz zarządzanie w działalności bieżącej. Niedobór majątku powoduje stagnację lub ograniczenie podaży usług oraz obniżenie ich jakości. Równowaga usług i majątku oznacza racjonalną sytuację, natomiast nadprodukcja usług, dzięki zbyt dużemu potencjałowi wytwarzania, charakteryzuje się nieefektywnością, z tytułu ponoszenia nadmiernych kosztów ekonomicznych. Utrzymanie zbędnego w danej chwili potencjału usługowego musi mieć uzasadnienie ekonomiczne lub społeczne. Niedobór usług inicjuje podjęcie zwykle dużego wysiłku inwestycyjnego, który w pewnych rodzajach majątku, wymaga dłuższego czasu dla zrealizowania przedsięwzięcia gospodarczego.

Drugi punkt widzenia (ekonomiczny), dotyczy oceny efektywnościowej i związany jest z pytaniem, czy i na ile, majątek komunalny ma być traktowany jako źródło generowania dochodów budżetowych? Po stronie dochodów w budżecie samorządu istotną pozycją mogą być dochody majątkowe, przybierające różne kwoty w zależności od polityki i zarządzania mieniem komunalnym. Dochody z tytułu majątku mają różne formy i wielkości. Zwykle mają one charakter jednorazowy i niepowtarzalny (sprzedaż, prywatyzacja). Dochodami z majątku są różnego rodzaju wpływy z dzierżawy, najmu, z tytułu korzystania z konkretnego składnika majątku komunalnego. W literaturze przedmiotu zwraca się uwagę, że istnieje związek majątku i gospodarki samorządu $\mathrm{z}$ finansami publicznymi, zwłaszcza w realizacji funkcji alokacyjnej. Przez system finansowania dokonywana jest bowiem alokacja zasobów w dziedzinach, gdzie mechanizm regulacji rynkowej okazuje się zawodny ${ }^{14}$.

Podmioty mienia komunalnego samodzielnie decydują o przeznaczeniu i sposobie wykorzystania poszczególnych składników majątkowych, przy zachowaniu wymogów zawartych w odrębnych przepisach prawa. W gospodarce majątkiem istnieje

14 Andrzej K. Piasecki, Samorząd terytorialny i wspólnoty lokalne, Wydawnictwo Naukowe PWN, Warszawa 2009, s. 314-315. 
zatem samodzielność podmiotów mienia w podejmowaniu decyzji o przeznaczeniu i sposobie wykorzystania składników mienia komunalnego. Możliwe ograniczenia dotyczą jedynie właściwości poszczególnych organów w podejmowaniu decyzji, przestrzegania procedur uchwalania decyzji, stosowania form organizacyjnych gospodarowania majątkiem oraz przestrzegania zasad gospodarowania mieniem komunalnym uchwalonych przez organ stanowiący ${ }^{15}$. Odpowiedzialność za gospodarkę majątkiem jest rozczłonkowana podmiotowo i ponoszona przez kierowników poszczególnych jednostek organizacyjnych samorządu. Pełną odpowiedzialność ponosi organ wykonawczy, do którego kompetencji należy gospodarka majątkiem komunalnym. Każdy z podmiotów mienia komunalnego podejmuje autonomiczne decyzje majątkowe. Prawa zwierzchnie w stosunku do tego typu podmiotów posiada jednostka samorządowa. Organy samorządu mogą wpływać na przeznaczenie oraz wykorzystanie składników majątkowych. Jeśli dany podmiot został postawiony w stan likwidacji, wówczas jego majątek przekazuje się podmiotowi wskazanemu przez organ stanowiący.

W gospodarowaniu mieniem komunalnym gminę reprezentuje organ wykonawczy, który składa w tym zakresie oświadczenie woli. Wójt, burmistrz, prezydent miasta może tę prerogatywę przenieść na swojego zastępcę, samodzielnie albo na niego wraz z inną upoważnioną osobą. W gospodarce majątkiem, jeżeli działalność dotyczy powstałych zobowiązań pieniężnych, niezbędna jest kontrasygnata skarbnika gminy (głównego księgowego budżetu) lub osoby przez niego upoważnionej. Odmowa kontrasygnaty przez skarbnika, a następnie dokonana na pisemne polecenie organu wykonawczego wymaga powiadomienia o tym organu stanowiącego gminy oraz regionalną izbę obrachunkową. Organy gminy podejmując uchwały i zarządzenia dotyczące zobowiązań finansowych muszą wskazać źródła, z których zobowiązania te będą pokryte.

Wykorzystanie i rozwój zasobów majątkowych powinny odbywać się według określonych zasad, regulujących ekonomiczne działania zarządzających. Zasady te powinny należeć do uprawnień organu stanowiącego i wykonawczego. Są to następujące zasady:

- zespolenia gospodarki i polityki majątkowej (integracji),

- celowości (adekwatności do wielkości i struktury zadań),

- preferencji (działanie zgodne z priorytetami rozwojowymi),

- ekonomizacji (stosowanie jako podstawy rachunku ekonomicznego),

- elastyczności (dostosowania się do zmian zachodzących w otoczeniu),

- partnerstwa (jako płaszczyzny współpracy i współdziałania),

- zgodności z regulacjami przestrzennymi.

Zasada zespolenia polega na dążeniu do łącznego traktowania gospodarki majątkowej i realizacji polityki majątkowej. Gospodarka majątkiem odnosi się do działalności bieżącej samorządu, w której zachodzą procesy zużycia składników majątkowych, utrzymania urządzeń według obowiązujących wymagań

15 Maciej J. Nowak, Mienie komunalne, „Gazeta Samorządu i Administracji” 2016, nr 9, s. 22. 
oraz dbałość o efektywne ich wykorzystanie. Polityka majątkowa wymaga jej stworzenia w sensie koncepcyjnym, a następnie wprowadzenia w życie. Stanowi działalność komplementarną wobec gospodarki majątkiem i wynika z oceny dotychczasowej gospodarki. Stwierdzenie istotnego zużycia moralnego i technicznego np. komunalnych zasobów mieszkaniowych, czy infrastruktury sieciowej jest przesłanką dla polityki szczegółowej w wyborze kierunku dalszego postępowania. Do rozważenia pozostają wtedy m.in. następujące rozwiązania: nie dokonywać zmian, rozpocząć remonty na szeroką skalę, przyjąć umiarkowany zakres remontów przy równoczesnym rozpoczęciu nowych inwestycji, utrzymać remonty na minimalnym poziomie oraz podjąć sprzedaż części zasobów majątkowych. Analizy ekonomiczne wskazują na istnienie zjawiska luki remontowej mieszkań komunalnych $\mathrm{w}$ średnich i w dużych miastach $\mathrm{w}$ świetle niezaspokojonych potrzeb, w zakresie zasobów komunalnych i socjalnych ${ }^{16}$. Szerzej o gospodarce tymi zasobami piszą B. Kluza i K. Kluza ${ }^{17}$.

W zasadzie zespolenia należy zwrócić uwagę na jej szczególny aspekt, uwzględniający dwa typy działalności, składające się na całość. Działalność ta obejmuje decyzje w dwóch sferach: inwestycji i eksploatacji, które ekonomicznie są komplementarne i substytucyjne ${ }^{18}$. W każdej z tych działalności ponoszone są koszty, a często występującą nieprawidłowością jest zawężanie kryterium oceny i wyboru (na ogół minimalizacji) tylko do jednego z tych etapów. Stanowi to przykład odejścia od kompleksowości analizy decyzyjnej i skupienia uwagi tylko na stronie inwestycyjnej lub eksploatacyjnej. Planowanie i realizacja minimalnego (bardzo oszczędnego) zakupu inwestycyjnego może w przyszłości prowadzić do wyższych kosztów jej eksploatacji. Odwrotnie, nadmierna redukcja kosztów eksploatacji urządzeń, która musi prowadzić do zaniedbania wielu funkcji, powoduje następnie niezbędność większych inwestycji, w tym pokrywających koszty awarii. W zastosowaniu całościowego rachunku kosztów i korzyści należy kierować się minimalizacją łącznych kosztów eksploatacyjnych oraz inwestycyjnych.

Zasada celowości (adekwatności) odnosi się do przedmiotu działalności samorządu. Istotą wykorzystania posiadanego majątku jest służenie dla realizacji zadań publicznych oraz podejmowania przedsięwzięć dla uzyskania korzyści społecznych i gospodarczych. Majątek tworzy potencjał wyznaczający zdolność samorządu do świadczenia określonej podaży i struktury usług. Z reguły, jak zaznaczono, wielkość i struktura majątku komunalnego powinna być adekwatna

16 Mieszkania socjalne zapewniające minimalny standard też stanowią własność komunalną i są przeznaczone dla osób o niskich dochodach lub znajdujących się w bardzo trudnej sytuacji życiowej.

17 B. Kluza, K. Kluza, Mieszkania komunalne - wyzwania dla polityki mieszkaniowej państwa w świetle badań wybranych miast, „Urban Development Issues” 2020, vol. 67, s. 75-84.

18 Określenie w tej mierze sekwencji nie ma uzasadnienia, bowiem występuje tutaj relacja na zasadzie sprzężenia zwrotnego. Pierwotne może być przedsięwzięcie inwestycyjne wpływające następnie na wzrost wielkości majątku i odwrotnie, z potrzeb majątkowych wynika konieczność dokonania określonej inwestycji. 
do poziomu oraz struktury wykonywanych zadań publicznych. W rzeczywistości, zasób majątkowy (potencjał) jest większy w stosunku do potrzeb związanych bezpośrednio $\mathrm{z}$ realizacją zadań własnych. $\mathrm{Z}$ zasadą celowości łączy się zasada elastyczności, nakłaniająca do szybkiego reagowania na zmiany zachodzące w otoczeniu samorządu. Odniesieniem jest ocena przydatności poszczególnych składników majątku komunalnego z punktu widzenia interesów samorządu. Jeśli element majątku nie jest zagospodarowany ekonomicznie, należy szybko się go pozbyć przez sprzedaż. W przeciwnym razie, ponoszone są koszty finansowe i społeczne nie dające efektów. Elastyczność w gospodarce majątkiem nie oznacza szybkości podejmowania decyzji, ale umiejętność przyjmowania racjonalnych postaw organów zarządzających. Polegają one na adaptacji do zmieniających się sytuacji i prowadzeniu polityki reaktywnej lub rozpoczęciu polityki innowacyjnej, wyprzedzającej w czasie, możliwe zmiany sytuacji majątkowej.

Zasada preferencji w gospodarce majątkowej oznacza konieczność działania według priorytetów rozwojowych i wiąże się z hierarchizacją celów szczegółowych w polityce samorządowej. Dokonywanie racjonalizacji działalności eksploatacyjnej wymaga identyfikacji „najsłabszych” ogniw i skupienia na nich uwagi. Realizacja postulatu ograniczenia wydatków budżetowych na cele administracyjne (np. o 10\%), nie daje nic dobrego, ponieważ potrzeby redukcji kosztów rozkładają się nierównomiernie w komórkach organizacyjnych urzędu lub $\mathrm{w}$ administracji wyłączonej z centralnego kierownictwa (np. wyspecjalizowane zarządy). Priorytety dotyczą zarówno działalności bieżącej, jak i inwestycyjnej. Wykorzystanie majątku komunalnego dla celów publicznych nakazuje jego ekonomizację, czyli gospodarowanie w sposób racjonalny, zgodnie z interesem samorządu i zmieniającymi się potrzebami mieszkańców. Tłem dla gospodarowania majątkiem powinno być myślenie ukierunkowane na osiąganie jak największych efektów ekonomicznych i społecznych z posiadanego potencjału. Z drugiej strony, należy szukać takich rozwiązań organizacyjnych i ekonomicznych, aby ponosić możliwie najmniejsze koszty z tym związane ${ }^{19}$. Zarządzanie majątkiem powinno zatem przynosić dochody budżetowe lub absorbować możliwie najmniejsze (uzasadnione) koszty związane z jego eksploatacją. Dodatkowo, należy brać pod uwagę cykl życia składnika majątku, skorelowany z wielkością świadczonych usług oraz liczbą usługobiorców ${ }^{20}$.

Problemem jest gospodarowanie elementami majątku w celach komercyjnych. Dotyczy to różnych składników, takich jak tereny (grunty), lokale mieszkalne i użytkowe, budowle i urządzenia techniczne. Posiadanie wolnych terenów lub ich zakup można uzasadnić zapewnieniem utrzymania rezerwy gruntów, które można zagospodarować przez pewien czas i sprzedać w przyszłości z zyskiem. Wyremontowane budynki komunalne można wynajmować na cele mieszkalne lub

19 Oznacza to kierowanie się dwoma aspektami klasycznie pojmowanej zasady racjonalnego gospodarowania (wydajności i gospodarności).

20 M. Wakuła, Wybrane problemy zarządzania finansami gmin, Zeszyty Naukowe Akademii Podlaskiej w Siedlcach, nr 82, Siedlce 2009, s. 111-112. 
gospodarcze, z zapewnieniem odpowiedniego narzutu zysku. Posiadanie instalacji (spalarnia, sortownia) do zagospodarowania odpadów może przynosić samorządowi korzyści finansowe przez ich przejęcie i prowadzenie działalności (również na rzecz innych samorządów). Posiadanie majątku stwarza wiele możliwości pozyskania środków finansowych. Majątek komunalny wymaga jednak nakładów finansowych dla jego utrzymania i modernizacji. Dochody z majątku komunalnego mogą kształtować się różnie $\mathrm{w}$ zależności od specyfiki samorządu oraz polityki jego $w_{\mathfrak{a d}} \mathrm{z}^{21}$. Nie ma merytorycznego uzasadnienia dla utrzymywania majątku, wymagającego nakładów, a który nie będzie w pełni wykorzystywany w przyszłości. Bardzo często tak tworzony majątek odbywa się pod presją społeczną, pozostającą w kolizji z zasadą efektywności. Dużą umiejętnością jest sprzedaż składników majątku w dobrej koniunkturze, które są zbędne lub "martwe” w realizacji zadań własnych. Wiele miast zachowuje jednak mniejszościowe udziały w spółkach handlowych, na które nie ma wpływu, a które są niepotrzebne z punktu widzenia interesu tych samorządów, co jest ekonomicznie niezrozumiałe.

Podsumowując tę część rozważań należy stwierdzić, że zarządzanie składnikami majątkowymi powinno odznaczać się racjonalnością i efektywnością. Po drugie, majątek winien tworzyć i stanowić logiczną całość dla realizacji długofalowej polityki rozwoju ${ }^{22}$. Potencjał majątkowy wyznacza bowiem zdolność samorządu do świadczenia określonej podaży i struktury usług publicznych. Zasadą jest, by posiadanie i użycie majątku było adekwatne do wielkości i struktury potrzeb, z zachowaniem pewnego marginesu rezerwy, przy czym dotyczy to bardziej usług technicznych, niż społecznych. Obserwacja praktyki samorządów wskazuje, że występują przypadki nieracjonalnych decyzji powodujących marnotrawstwo (rozrzutność), zamrożenie aktywów, postawy korupcyjne, czy naruszanie przepisów prawa. Obszar gospodarki samorządu jest pełen przykładów takich zjawisk. Można zauważyć, że ułomności gospodarki majątkowej tkwią też w samym procesie zarządzania publicznego, a nie tylko w niedostatku mienia. Związek gospodarki majątkowej z planowaniem przestrzennym polega na postępowaniu zgodnym z ustaleniami wynikającymi z planu zagospodarowania przestrzennego. Plany przestrzenne jako akty prawa miejscowego, określają przeznaczenie terenu, sposoby i warunki jego zagospodarowania oraz zabudowy. Są zatem podstawą podejmowania decyzji inwestycyjnych i narzędziem racjonalnie prowadzonej gospodarki przestrzennej.

21 A. Hanusz, A. Niezgoda, P. Czerski, Dochody budżetu jednostek samorzq̨du terytorialnego, Oficyna a Wolters Kluwer business, Warszawa 2009, s. 20.

22 B. Filipiak, Kierunki zarządzania finansami w jednostkach samorządu terytorialnego a problemy utrzymania płynności finansowej, „Finanse Komunalne” 2004, nr 3. 


\section{Rozdział IX}

\section{Finansowanie dziatalności rozwojowej Rola nadwyżki operacyjnej}

Obok świadczenia usług publicznych, komplementarną częścią działalności samorządu jest kształtowanie warunków dla szeroko pojmowanego rozwoju. Sama otwartość i przyjazność samorządu są niewystarczające do tego. Organy samorządu muszą więc podejmować wysiłek inwestycyjny dla powiększenia zasobu majątku komunalnego, wykorzystywanego w różny sposób - zgodnie z celami i priorytetami polityki lokalnej. Stąd, powszechne przekonanie, że warunkiem rozwoju samorządu są inwestycje jest niepełne, ponieważ są równie potrzebne i niezbędne dla zapewnienia warunków sprawnego dostarczania usług publicznych. W literaturze przedmiotu, wyrażany jest pogląd o związku zdolności do inwestowania $\mathrm{z}$ potencjałem endogenicznym, stanowiącym warunek kształtowania rozwoju. Jednostki samorządu, które charakteryzują się niską zdolnością do inwestowania posiadają ograniczony potencjał. Takie samorządy mają jeszcze wiele niezrealizowanych zadań inwestycyjnych, o charakterze podstawowym. Mała atrakcyjność inwestycyjna sprawia, iż popadają one stopniowo w regres gospodarczy ${ }^{1}$.

W niniejszych rozważaniach, inwestycje będą traktowane wąsko i tradycyjnie, jako nakłady gospodarcze, których celem jest odtworzenie bądź powiększenie zasobu majątku trwałego. Działanie polegające na modernizacji procesu wytwarzania produktu i usługi może dotyczyć zarówno odtworzenia, jak i zwiększenia majątku trwałego (zdolności produkcyjno-usługowej). Inwestycje w gospodarce samorządu odznaczają się pewnymi cechami, które wywołują za sobą konsekwencje polityczne, społeczne oraz ekonomiczne (finansowe). Do cech tych zaliczamy:

- miejscowy i lokalny charakter inwestycji,

- związek inwestycji z elementami infrastruktury technicznej i społecznej oraz częściowo administracyjnej².

1 M. Zioło, Aktywność inwestycyjna samorządu terytorialnego w Polsce w latach 1999-2005, [w:] Harmonizacja finansów publicznych w skali narodowej i europejskiej, (red.) K. Piotrkowska-Marczak, K. Kietlińska, Wydawnictwo Difin, Warszawa 2007, s. 493.

2 Użycie terminu infrastruktura administracyjna ma charakter pragmatyczny i dotyczy tej części majątku publicznego (trwałego), która jest wykorzystywana przez administrację samorządową 
Z faktu takiej przynależności wynikają różne kolejne konsekwencje związane $z$ innymi cechami infrastruktury:

- współistnienie cyklu inwestycyjnego z cyklem politycznym,

- część inwestycji infrastrukturalnych jest uzasadnionych społecznie i mniej ekonomicznie.

Inwestycje realizowane przez samorząd, dotyczą przede wszystkim szeroko rozumianej infrastruktury komunalnej, umożliwiającej wykonywanie zadań publicznych.

Samorząd w Polsce jest nie tylko usługodawcą, ale również inwestorem. Najwięcej środków przeznaczał na inwestycje w latach 2009-2011, a od 2012 r. nastąpiło niewielkie wyhamowanie (spowolnienie). Według K. Kluzy, inwestycje samorządowe uratowały polską gospodarkę przed kryzysem (2008), ale znacznie pogorszyły kondycję finansową samorządu ${ }^{3}$. Nie wszystkie jednak inwestycje w samorządzie były racjonalne i przemyślane, tak z punktu widzenia ekonomicznego, jak i społecznego. Niektóre z nich, po oddaniu do użytkowania generują dodatkowe koszty, powodujące wzrost wydatków bieżących ${ }^{4}$. Samorządy powinny na początku realizować przedsięwzięcia, które mogą przyczyniać się do uzyskania dodatkowych wpływów do budżetu, np. budowa wodociągu lub kanalizacji (wraz z częściową pomocą, w niektórych przypadkach wykonania przyłączy), modernizacja komunalnych zasobów mieszkalnych (poprzez podniesienie standardu lokali), budowa lub adaptacja lokali na przedszkola itp., bądź rozwiązać „palący” problem społeczny ${ }^{5}$. Zadaniem A. Zalewskiego, między finansami samorządu a rozwojem lokalnym występuje sprzężenie zwrotne. Samorząd musi ponieść najpierw wydatki na infrastrukturę, aby mógł dokonać się rozwój społeczno-gospodarczy, przynoszący następnie dochody budżetowe po zrealizowaniu inwestycji $\mathrm{z}$ nim związanych 6 .

w świadczeniu usług administracyjnych za pomocą różnych komunikatorów. Z równym powodzeniem można infrastrukturę administracyjną zaliczyć do infrastruktury społecznej.

3 K. Kluza, Zadłużenie jednostek samorządu terytorialnego w Polsce. Trendy historyczne, narzędzia do analizy zdolności spłaty zadłużenia oraz postulaty zmian systemowych, Instytut Rozwoju Miast i Regionów, Warszawa 2019, s. 50-53.

4 Budowa filharmonii, hal, stadionów, aquaparków itp. to taki rodzaj inwestycji, które dla sektora prywatnego są nieopłacalne, a dla samorządu te drogie obiekty, po oddaniu do użytku powodują wzrost wydatków w budżecie. Wiele samorządów zrealizowało inwestycje typu: budowa fontanny (np. w Łodzi to koszt ponad 15 mln zł wraz z przebudową placu, a koszt eksploatacji w okresie 6,5 miesiąca to ok. 200 tys. zt), budowa lub adaptacja budynku na centrum konferencyjne i wystawiennicze (bądź podobne), budowa stadionów (np. dwóch miejskich w Łodzi), pomników, wież widokowych itd. Z punktu widzenia sektora prywatnego będzie to działanie nieefektywne.

5 Przykładowo, w gminie Wierzchosławice (woj. małopolskie) zbudowano liczne pomniki. Jest też całoroczne lodowisko, z którego nikt nie korzysta, bo gmina nie ma fachowca, który dobrze oszlifowatby taflę lodu. Wybudowano także kryty basen rehabilitacyjny, ale zamknięty dla mieszkańców. Jest farma fotowoltaiczna, która zamiast słonecznych zysków przynosi budżetowi ok. miliona złotych strat rocznie.

6 A. Zalewski, Problemy i metody prognozowania wptywu rozwoju lokalnego na finanse gminy, [w:] Gospodarka lokalna i regionalna w teorii i praktyce, Prace Naukowe Uniwersytetu Ekonomicznego we Wrocławiu nr 46, Wroctaw 2009, s. 183. 
Samorząd chcąc inwestować oraz korzystać ze środków Unii Europejskiej, sukcesywnie zadłużał się (na wkład własny). Bez wątpienia, pozyskane środki unijne stanowią istotną pomoc w finansowaniu wielu ważnych przedsięwzięć rozwojowych w samorządzie. Jednakże istnieją przesłanki wskazujące, że nie należy ich traktować jako główny środek na podejmowanie działalności inwestycyjnej. Udział środków unijnych w strukturze dochodów samorządowych nie przekraczał 10\%, a od 2013 r. wykazuje stopniowy spadek. Uwzględniając duży odsetek tzw. projektów miękkich oraz nie zawsze "trafione” inwestycje rozwiązujące problem, można przypuszczać, że faktyczny wpływ tych środków może być słabszy od oczekiwanego. Obserwacja praktyki gospodarczej w samorządach ${ }^{7}$ potwierdza występowanie zjawiska niegospodarności oraz marnotrawstwa i tak ograniczonych środków finansowych ${ }^{8}$. Przypadki te są trudniejsze do zidentyfikowania w dużych samorządach, gdzie realizatorów budżetu jest dużo i w "gąszczu” wydatków klasyfikacji budżetowej można wiele ukryć. Sytuacja ta w kontekście zdobycia dużym wysiłkiem środków zewnętrznych (wymagających na ogół zaciągnięcia długu), stwarza nową perspektywę patrzenia na zbyt optymistyczne pozyskiwanie funduszy unijnych.

Jak zaznaczono, niektóre inwestycje komunalne mogą przynosić, nawet w relatywnie krótkim czasie, wymierny dochód do budżetu samorządu. Inwestycje jako przyszłe źródło dochodów budżetowych obejmują przede wszystkim:

- przedsięwzięcia przynoszące bezpośredni dochód z ich eksploatowania (np. wybudowanie lokali użytkowych bądź mieszkalnych, podłączenie do sieci wodociągowej, kanalizacyjnej, cieplnej, pewnej liczby użytkowników wnoszących opłaty zapewniające dochód budżetu),

- inwestycje wpływające na zwiększenie dochodów budżetu, dzięki wykorzystaniu efektów tych inwestycji do prowadzenia działalności gospodarczej przynoszącej dochód,

- inwestycje nie przynoszące bezpośrednio określonego dochodu do budżetu, lecz pośrednio powodujące wzrost tych dochodów z tytułu wzrostu podatków i opłat związanych z bogaceniem się ludności i przedsiębiorstw (np. miejsca pracy, wzrost przedsiębiorczości).

Gdy podejmowane są decyzje inwestycyjne o charakterze obsługowym, to zwykle generują one koszty od zaraz, zaś w przypadku inwestycji rozwojowych nastawionych na pozyskanie dochodów, efekty ujawniają się w dłuższym czasie. Zawsze trzeba kierować się zasadą, iż zadłużenie powinno wiązać się z działalnością inwestycyjną, a nie z działalnością bieżącą (tzw. złota reguła zrównoważenia budżetu w działalności bieżącej).

Kluczową sprawą $\mathrm{w}$ finansowaniu działalności rozwojowej jest identyfikacja ich źródeł. Problem polega na poszukiwaniu najbardziej korzystnych

7 Jak też przegląd dokumentacji pokontrolnej Najwyższej Izby Kontroli oraz regionalnych izb obrachunkowych.

8 Np. budowa podziemnej (i rozbudowanej) stacji kolejowej dla Łodzi Fabrycznej, czy później drążenie tunelu pod miastem (łącznie za ponad 2 mld zt) wygląda na nieuzasadnione ekonomicznie projekty, nawet jeśli uwzględnimy wszystkie możliwe korzyści społeczne. 
i alternatywnych sposobów pozyskania środków finansowych. Ogólnie możliwe są dwie grupy źródeł - źródła wewnętrzne i zewnętrzne. W finansowaniu rozwoju samorządu szczególną rolę odgrywa kategoria nadwyżki operacyjnej. Stanowi jeden z najważniejszych parametrów (miar, barometrów), charakteryzujących syntetycznie stan kondycji finansowej jednostki samorządowej. Nie może jednak dać pełnej informacji o stanie gospodarki finansowej, gdyż nie uwzględnia dochodów i wydatków majątkowych oraz przychodów i rozchodów budżetu. Pojęcie nadwyżka operacyjna nie zostało dotychczas zdefiniowane w polskim prawie finansowym, niemniej pojawia się ono w praktyce zarządzania finansami samorządowymi. Nadwyżka operacyjna została wprowadzona do życia finansowego jako wymóg prawny w $2011 \mathrm{r}$. Można powiedzieć, że poziom nadwyżki operacyjnej w budżetach jednostek samorządowych do 2014 r. nie miał formalnego znaczenia, gdyż zaczęła już obowiązywać formuła limitacji zadłużenia zawarta w art. 243 ustawy o finansach publicznych. Zmiana limitów zadłużania się samorządu spowodowała, że nadwyżka operacyjna stała się istotną miarą przy ocenie sytuacji finansowej, zdolności do spłaty rat od zaciągniętych kredytów, pożyczek, czy wykupu wyemitowanych obligacji oraz możliwości samodzielnego finansowania inwestycji.

Nadwyżka dochodów bieżących nad wydatkami bieżącymi uznawana jest za ważną wielkość ekonomiczną, ponieważ informuje o wysokości środków finansowych, które samorząd może przeznaczyć na inwestycje, albo co najmniej na spłatę zadłużenia9 . W świetle przepisów prawa, nadwyżka operacyjna ustalana jest jako dodatnia różnica między bieżącymi dochodami budżetowymi a bieżącymi wydatkami budżetowymi, powiększona o określone przepisami prawa przychody z poprzednich okresów ${ }^{10}$. Wielkość wypracowanej nadwyżki operacyjnej identyfikuje zakres wydatków budżetowych (bieżących i majątkowych) możliwych do sfinansowania dochodami bieżącymi. Wysokość nadwyżki operacyjnej ma wpływ na zakres wykorzystywania przez poszczególne samorządy zewnętrznych źródeł finansowych ${ }^{11}$. Im wyższa jest wartość nadwyżki operacyjnej, tym większa jest możliwość realizacji przez jednostkę samorządową nowych przedsięwzięć inwestycyjnych ${ }^{12}$.

Należy zauważyć, że nadwyżka operacyjna obrazuje rzeczywiste możliwości „udźwignięcia” kosztów obsługi zewnętrznego kapitału zwrotnego. Ma zatem znaczenie dla realizowanej polityki finansowej (w tym właściwego zarządzania długiem), odpowiednio ją kreując. Wynik operacyjny jest ważną miarą możliwości zaciągania zobowiązań dłużnych oraz możliwości ich obsługi ${ }^{13}$. Jest to najbardziej

9 K. Surówka, Problem oceny poziomu zadłużenia jednostek samorzq̨du terytorialnego a realizacja zadań, „Finanse Komunalne” 2014, nr 9, s. 5-10.

10 Art. 242 ustawy z dnia 27 sierpnia 2009 r. o finansach publicznych...

11 Dotyczy zwrotnych, jak i bezzwrotnych.

12 Zarówno bezpośrednio przeznaczając tę kwotę na inwestycje lub pośrednio - spłacając wcześniej zaciągnięte zobowiązania na cele inwestycyjne. Zob. E. Kornberger-Sokołowska, Wskaźnik zadłużenia a uwarunkowania funkcjonowania jednostek samorzqdu terytorialnego w warunkach zmiennej koniunktury gospodarczej, „Finanse Komunalne” 2015, nr 1-2, s. 37-42.

13 A. Borodo, System finansowy samorządu terytorialnego w Polsce, Dom Organizatora, Toruń 2011, s. 173. 
syntetyczna ocena kondycji finansowej samorządu, potencjału inwestycyjnego samorządu oraz zdolności kredytowej. Informuje jakimi środkami dysponuje samorząd, po sfinansowaniu podstawowych potrzeb bieżących. Gdyby jednostka osiągnęła ujemny wynik na działalności bieżącej (deficyt operacyjny) oznaczałoby to, że wydatki bieżące realizowane są na poziomie przekraczającym możliwości finansowe. Wobec tego wykonywanie zadań bieżących odbywa się kosztem wysprzedaży majątku jednostki lub przez zaciąganie nowych zobowiązań dłużnych. Mogłoby to doprowadzić do nadmiernego wzrostu zadłużenia wraz z kosztami jego długu lub niższym niż zakładano, wzrostem dochodów budżetowych jednostki ${ }^{14}$.

Prawny obowiązek równoważenia działalności bieżącej ma na celu zachowanie właściwych proporcji wielkości ekonomicznych, już na etapie planowania. Dotyczy także kształtowania właściwej relacji w odniesieniu do wielkości rzeczywiście osiągniętych na koniec roku budżetowego. Zapobiec ma to sytuacji, w której jednostka samorządowa nie jest w stanie ponieść kosztów zadłużenia długoterminowego i zmuszona zostaje do zaciągnięcia nowego długu dla sfinansowania już istniejącego. Można powiedzieć, że równowaga w działalności bieżącej stanowi kolejną, obok wskaźników zadłużenia, restrykcję wpływającą na działalność samorządu. Trzeba dodać, że spełnienie warunku równowagi w działalności bieżącej dla niektórych jednostek może być trudne. Jest to problemem dla jednostek, które pozbawione zostały faktycznego władztwa podatkowego (powiaty) oraz dla jednostek, które dysponują mało wydajnymi źródłami bieżących wpływów i nie mają realnych możliwości ich intensyfikacji. Koncepcja federalizmu fiskalnego dostarcza argumentów za finansowaniem kredytowym, zamiast finansowania inwestycji $\mathrm{z}$ dochodów bieżących ${ }^{15}$. Wydaje się, że w samorządzie nie jest to przekonujące, ponieważ spłata zaciągniętych kredytów, siłą rzeczy, musi oprzeć się o źródła z dochodów bieżących (podatków i opłat). Spłata zobowiązań długoterminowych z dochodów ze sprzedaży majątku komunalnego nie jest realna, gdyż stanowią one niewielki udział w ogólnym zadłużeniu.

Podsumowując, należy podkreślić, że nałożona na jednostki samorządowe ${ }^{16} \mathrm{za}^{-}$ sada równoważenia działalności bieżącej (operacyjnej), stwarza konieczność innego podejścia do polityki finansowej samorządu. Jej celem staje się wypracowanie przez jednostkę możliwie największej nadwyżki operacyjnej. Generowanie nadwyżek operacyjnych i budżetowych jest wymieniane jako jeden z czynników kreujących potencjał finansowy samorządó $w^{17}$. Jednocześnie odmiennego znaczenia ( $w$ tych uwarunkowaniach prawnych) nabiera polityka zadłużania się samorządu i zarzą-

14 Ministerstwo Finansów, Nadwyżka operacyjna w jednostkach samorządu terytorialnego w latach 2007-2009, Warszawa 2010, www.mf.gov.pl.

15 P. Swianiewicz, Finanse samorządowe, koncepcje, realizacja, polityki lokalne, Wydawnictwo Municipium, Warszawa 2011, s. 157.

16 Jako ustawowy obowiązek od $2011 \mathrm{r}$.

17 B. Filipiak, Dylematy pomiaru potencjału finansowego jednostek samorzadu terytorialnego - dobór czynników i ich pomiar, Prace Naukowe Uniwersytetu Ekonomicznego we Wrocławiu nr 451, Wrocław 2016, s. 75-88. 
dzania długiem w różnych przedziałach czasowych. Zbyt wysoki przyrost wydatków bieżących w relacji do dynamicznych zmian dochodów prowadzi do obniżenia potencjału inwestycyjnego, a tym samym spowolnienia procesów rozwoju lokalnego ${ }^{18}$.

Nadwyżka operacyjna może być pomocna przy tworzeniu wskaźników finansowych, które będą przydatne w ocenie możliwości finansowania wydatków inwestycyjnych (majątkowych) środkami własnymi. Do tego typu wskaźników należą m.in.:

- udział nadwyżki operacyjnej w dochodach ogólem,

- udział nadwyżki operacyjnej w zobowiązaniach ogółem,

- wskaźnik samofinansowania,

- udział nadwyżki operacyjnej w wydatkach bieżących,

- udział nadwyżki operacyjnej w dochodach bieżących.

Pierwszy z wskaźników obrazuje zdolność do ponoszenia wydatków inwestycyjnych, a także możliwość zaciągania długu i zwiększenia wydatków bieżących. Pozytywnym zjawiskiem jest więc wzrost wysokości tego wskaźnika. Następny wskaźnik służy do oceny wiarygodności kredytowej, gdyż pokazuje możliwości zadłużania się jednostki samorządowej w stosunku do wypracowanej nadwyżki operacyjnej. Zmiana wielkości tego wskaźnika wskazuje również na realność finansowania inwestycji ze środków własnych na tle kształtowania się wielkości zobowiązań samorządu (ocenia zdolność do finansowania wydatków inwestycyjnych w relacji do posiadanego zadłużenia). W konsekwencji, pozytywnym zjawiskiem jest tendencja wzrostowa tego wskaźnika, a przynajmniej jego względna stabilizacja, w okresie realizowania licznych inwestycji przez jednostkę samorządową.

Wskaźnik samofinansowania ${ }^{19}$ obrazuje m.in. w jakim stopniu jednostka jest w stanie finansować zadania inwestycyjne, środkami własnymi. Stąd wzrost wartości tego wskaźnika oznacza zmniejszanie się ryzyka utraty płynności przez daną jednostkę. Jednakże zbyt wysoki poziom tego wskaźnika może oznaczać swego rodzaju bierność $\mathrm{w}$ realizacji inwestycji przez władze samorządu, w odniesieniu do własnych możliwości finansowych. Kolejny wskaźnik zwraca uwagę na wysokość obciążenia samorządu wydatkami bieżącymi. Oddanie do użytkowania zakończonej inwestycji, pociąga za sobą konieczność ponoszenia określonych wydatków (np. koszty konserwacji, eksploatacji, funkcjonowania), co powoduje wzrost wydatków bieżących. W efekcie, wielkość tego wskaźnika może wskazywać na zbyt wysokie obciążenie wydatkami bieżącymi. Ostatni z wymienionych wskaźników ukazuje możliwości zwiększania wydatków bieżących. W tym przypadku, wzrost wartości tego wskaźnika może stworzyć większe możliwości podejmowania nowych inwestycji przez jednostkę samorządową.

Występowanie nadwyżki operacyjnej w budżecie samorządu jest niewątpliwie pozytywnym zjawiskiem, jednakże samo jej istnienie (nawet nadwyżki relatywnie dużej w stosunku do dochodów) nie przesądza jeszcze o jej dobrej kondycji

18 J. Sierak, Komunalna luka infrastrukturalna a możliwości budżetowe gmin w jej ograniczaniu..., s. 253.

19 Wskaźnik samofinansowania $=($ nadwyżka operacyjna + dochody majątkowe $) /$ wydatki majątkowe. 
finansowej ${ }^{20}$. Jak słusznie zauważa M. Dylewski, pozycję finansową jednostki samorządowej wzmocniono, przez wprowadzenie istotnego ograniczenia w zakresie możliwości finansowania wydatków bieżących instrumentami dłużnymi, a w zasadzie taką możliwość wykluczono ${ }^{21}$. Według K. Surówki, wydatki na inwestycje powinny być skorelowane $\mathrm{z}$ wielkością wypracowanych nadwyżek operacyjnych $^{22}$. M. Bitner wskazuje, że w wielu krajach zasada równoważenia budżetu w części działalności bieżącej, ma zasadnicze znaczenie w całościowej koncepcji równowagi budżetowej ${ }^{23}$. W polskim samorządzie, korzystną tendencją jest zmniejszanie się liczby jednostek z ujemnym wynikiem działalności bieżącej. Najwięcej samorządów z deficytem operacyjnym występuje w grupie gmin wiejskich i miejsko-wiejskich. Jest to wytłumaczalne z następujących powodów: ich liczebność w skali kraju jest najwyższa, w tej grupie występują małe jednostki pod względem liczby ludności, w przestrzeni wiejskiej pojawia się problem rozproszenia zabudowy. W miastach na prawach powiatu oraz w województwach, praktycznie nie występowała nierównowaga w działalności bieżącej, gdyż w latach 2014-2019 deficyt operacyjny odnotowały tylko pojedyncze samorządy.

Tabela 2. Liczba samorządów z deficytem na działalności bieżącej w latach 2012-2019

\begin{tabular}{|l|c|c|c|c|c|c|c|c|}
\hline Jednostki samorządowe & $\mathbf{2 0 1 2}$ & $\mathbf{2 0 1 3}$ & $\mathbf{2 0 1 4}$ & $\mathbf{2 0 1 5}$ & $\mathbf{2 0 1 6}$ & $\mathbf{2 0 1 7}$ & $\mathbf{2 0 1 8}$ & $\mathbf{2 0 1 9}$ \\
\hline Gminy wiejskie & 33 & 12 & 29 & 34 & 7 & 7 & 9 & 11 \\
\hline Gminy miejsko-wiejskie & 28 & 9 & 15 & 7 & 4 & 3 & 7 & 9 \\
\hline Gminy miejskie & 23 & 5 & 3 & 3 & 2 & 4 & 3 & 5 \\
\hline Miasta na prawach powiatu & 3 & 3 & 1 & 0 & 0 & 1 & 0 & 1 \\
\hline Powiaty & 15 & 10 & 6 & 2 & 3 & 2 & 3 & 2 \\
\hline Województwa & 0 & 0 & 1 & 0 & 0 & 0 & 0 & 0 \\
\hline Ogółem & 102 & 39 & 55 & 46 & 16 & 17 & 22 & 28 \\
\hline
\end{tabular}

Źródto: opracowanie własne na podstawie danych Ministerstwa Finansów.

Wielkość nadwyżki operacyjnej (tabela 10 w załączniku) jest zróżnicowana według typów administracyjno-prawnych jednostek samorządowych. Największą

20 M. Wiewióra, Wpływ nadwyżki operacyjnej budżetu na kondycję finansowa jednostki samorządu terytorialnego, „Studia i Prace Kolegium Zarządzania i Finansów” 2008, z. 86, s. 147.

21 M. Dylewski, Nadwyżka operacyjna a decyzje finansowe jednostek samorządu terytorialnego, „Oeconomia” nr 6, Uniwersytet Marii Curie-Skłodowskiej, Lublin 2017, s. 80.

22 K. Surówka, Rola nadwyżki operacyjnej w finansowaniu działalności rozwojowej jednostek samorzqdu terytorialnego i zaspokajaniu potrzeb społecznych (na przykładzie gmin oraz miast na prawach powiatu w latach 2011-2017), „Finanse Komunalne” 2018, nr 7-8, s. 8.

23 M. Bitner, Prawne instrumenty ograniczenia deficytu budżetowego i długu publicznego jednostek samorządu terytorialnego, Wolters Kluwer, Warszawa 2016, s. 309. 
nadwyżkę wypracowują gminy bez miast na prawach powiatu, co jest zrozumiałe ze względu na liczebność tych gmin. Kolejno, najwyższą nadwyżkę operacyjną osiągnęły miasta na prawach powiatu, województwa i na końcu powiaty. Te ostatnie odznaczają się największą dynamiką wzrostu. Kształtowanie się nadwyżki $\mathrm{w}$ poszczególnych grupach jednostek samorządowych wskazuje na dyscyplinujący charakter nadzoru regionalnych izb obrachunkowych. Spowodował on aktywne poszukiwania oszczędności na działalności bieżącej, a pośrednio większe jej racjonalizowanie. Uzyskanie nadwyżki operacyjnej w powiatach stanowiło dla ich władz duży wysiłek organizacyjny, przy zastosowaniu wysokiego reżimu w gospodarowaniu (w ich przypadku) bardzo ograniczonymi środkami finansowymi. Jak już wykazano, na potencjał rozwojowy samorządu składają się trzy elementy:

- potencjał własny (nadwyżka operacyjna, dochody ze sprzedaży majątku),

- wsparcie (pomoc finansowa) zewnętrzne (dotacje z funduszy celowych krajowych i zagranicznych, z budżetu państwa i z UE),

- finansowanie zwrotne (uzależnione od indywidualnego wskaźnika zadłużenia i zdolności kredytowej).

$\mathrm{Z}$ analizy dynamiki nadwyżki operacyjnej w okresie zwiększonej aktywności inwestycyjnej polskiego samorządu (2006-2018) wynika, że własny potencjał rozwojowy kształtuje się odmiennie na różnych jego poziomach. Znaczne różnice występują w obrębie każdego stopnia samorządności. Można powiedzieć, że potencjał ten wynika z różnych uwarunkowań lokalnych i musi być rozpatrywany indywidualnie (na zasadzie case study).

Dochody uzyskiwane z zakończonych inwestycji, najczęściej nie są w stanie pokryć kosztów zaciągniętego długu (rata kapitałowa i odsetki). Tylko w zakresie nielicznych zadań, jak np. zaopatrzenie w wodę, energię, odprowadzanie i oczyszczanie ścieków, gospodarka odpadami, gospodarka mieszkaniowa, istnieje możliwość pozyskania środków w ramach świadczenia usług odpłatnych. Nie jest bowiem możliwe obciążenie np. użytkowników samorządowych dróg publicznych, parków, placów zabaw. Aspekt ten powinien być brany pod uwagę przy podejmowaniu decyzji, dotyczących kolejności przedsięwzięć inwestycyjnych, w powiązaniu z wielkością długu danego samorządu. Jak wykazał K. Kluza, wzrost aktywności inwestycyjnej samorządu w Polsce i w Europie jest skorelowany ze wzrostem ich zadłużenia, niezależnie od koniunktury gospodarczej ${ }^{24}$. Na wielkość wydatków inwestycyjnych wpływają czynniki o charakterze ekonomicznym i politycznym. O silnym oddziaływaniu ekonomicznym przesądzają możliwości finansowe danego samorządu (kształtowane przez rygory prawno-finansowe) oraz koniunktura gospodarcza w kraju i na świecie. Z kolei sfera polityczna zarządzania lokalnego związana jest z cyklem wyborczym, jakością zarządzania wykonawczego oraz presją organu stanowiącego, mieszkańców i jednostek pomocniczych.

24 K. Kluza, Efektywność polskich jednostek samorzq̨du terytorialnego na tle samorządów Unii Europejskiej - weryfikacja adekwatności dochodów, „Finanse Komunalne” 2014, nr 12, s. 19. 


\section{Rozdział X}

\section{Kategoria deficytu i zadłużenia}

Pojęcia te są ściśle za sobą związane i stanowią podstawowe elementy w analizie i ocenie sytuacji finansowej gospodarki samorządu. Prawie każda charakterystyka gospodarki finansowej samorządu podejmuje doniosłość deficytu i zadłużenia. Paradoksalnie deficyt i zadłużenie są jednocześnie zjawiskiem i procesem, ponieważ fakt ich występowania stanowi efekt kształtowania się innych kategorii ekonomicznych. Najogólniej ujmując, zadłużenie powstaje jako kumulacja deficytów z poprzednich okresów. Pomiędzy deficytem a zadłużeniem nie zachodzą wprost oczywiste zależności (spadkowi lub wzrostowi deficytu odpowiada również spadek lub wzrost zadłużenia). Mogą bowiem wystąpić różne sytuacje ze względu na określane kierunki zmian:

- zmniejsza się wielkość deficytu budżetowego, a równocześnie nie zmniejsza się wysokość długu jednostki samorządowej,

- brak ujemnego salda między dochodami i wydatkami, a zadłużenie nie maleje (wzrost lub stabilizacja),

- nie ma deficytu budżetowego i wielkość długu zmniejsza się,

- zwiększa się wielkość deficytu i jednocześnie zwiększa się zadłużenie,

- wyższy deficyt budżetowy nie powoduje wzrostu zadłużenia.

Zaciąganie zobowiązań na poczet nowych środków finansowych jest normalnym działaniem, nie tylko w gospodarce. Powstały w ten sposób dług, tworzy jednak sytuację szczególną w tym rozumieniu, że uzyskujemy nowe możliwości sfinansowania czegoś, bez własnych środków w danym momencie. J. Sierak, wśród korzyści zaciągania długu wymienia szansę przyspieszenia procesów rozwoju lokalnego oraz wzmocnienie lokalnej bazy ekonomicznej ${ }^{1}$.

Zadłużanie się stanowi mechanizm podobny do działania tzw. dźwigni finansowej ułatwiającej realizację przedsięwzięcia lub zadania publicznego. Niezbędne jest rozważenie trzech ważnych kwestii:

- bezpieczeństwa finansowego,

- moralności w zaciąganiu długów,

- granic zadłużania się.

1 J. Sierak, Finansowanie inwestycji gmin instrumentami dłużnymi - szanse i zagrożenia, „Nierówności Społeczne a Wzrost Gospodarczy” 2018, nr 56, s. 207. 
Dobrze jeśli zamyka się to $\mathrm{w}$ poczuciu bezpieczeństwa finansowego, które w przypadku zaciągania zobowiązań odpowiednio kosztuje. Gwarantem uzyskania takiego bezpieczeństwa jest monitorowanie procesu zadłużania się i pozostawianie długu publicznego pod skuteczną kontrolą. Jak pisze B. Filipiak, obowiązujący indywidualny wskaźnik zadłużenia, odnosi się jedynie do możliwości obsługi zadłużenia i nie może być miarą kondycji finansowej, pomija się bowiem zobowiązania inne niż zobowiązania dłużne. Niebranie pod uwagę tych zobowiązań i ich wpływu na kondycję finansową powoduje, że wskaźnik ten jest niedoskonały i niepełny ${ }^{2}$.

Zadłużanie się ma doniosły aspekt natury etycznej. Zdobycie tą drogą środków finansowych wymaga określonego kosztu, wyższego od nominalnej kwoty zobowiązania. Koszt ten jest obciążeniem nie tylko dla osób zarządzających, pozyskujących je bezpośrednio, ale w ostateczności dotyczy mieszkańców wspólnoty. To ci ostatni będą spłacać coraz wyższe zadłużenie, kosztem innych ważnych spraw do rozwiązania. Władze samorządu są w tym procesie jedynie czynnikiem sprawczym i pośrednikiem $\mathrm{w}$ transakcji finansowej w imieniu mieszkańców, których reprezentują. Otrzymując mandat zaufania do zarządzania, władze te mają to czynić w dobrze pojętym interesie publicznym bez czynnego udziału samych mieszkańców.

Istotną decyzją jest określenie granicy zadłużania się. Długotrwałe i rosnące zadłużenie to inaczej funkcjonowanie na koszt innych, bez zaciągnięcia ich opinii lub zgody w procedurze rządzenia demokratycznego. Wydaje się, że powinny być przyjęte prawnie, pewne pułapy ograniczające procesy zadłużania się $z$ dwóch powodów. Jednym, jest nałożenie niejako „hamulca” dalszego zadłużania, drugim - stworzenie szansy dla innych rządzących, którzy w przeciwnym razie są pozbawieni możliwości korzystania $\mathrm{z}$ tego instrumentu finansowego. Wysoki poziom zadłużenia zamyka praktycznie następcom drogę zaciągania zobowiązań długoterminowych, którzy siłą rzeczy muszą się wtedy skupić na działalności bieżącej, bez perspektyw rozwojowych. Zdaniem K. Surówki i K. Owsiak, indywidualny wskaźnik zadłużenia ogranicza wydatki inwestycyjne i stabilizację długu na tym samym poziomie ${ }^{3}$. Zatem do rozważenia pozostaje propozycja, aby określić w danej kadencji wskaźnik (parametr) zadłużania samorządu. Otwiera to dla kolejnych władz, pole do zwiększenia aktywności inwestycyjnej. Nadmierne zadłużanie, sprowadza następców do roli jedynie administrowania sprawami publicznymi w jednostce samorządowej.

Zadłużenie podsektora samorządowego jest konsekwencją stałego przyrostu deficytu w kolejnych latach, początkowo w miarę systematycznego, a w latach 2009-2012 bardzo dynamicznego. Po tym okresie do 2017 r. zauważa się

2 Beata Z. Filipiak, Indywidualny wskaźnik zadłużenia jako determinanta oceny kondycji finansowej jednostki samorządu terytorialnego, „Nierówności Społeczne a Wzrost Gospodarczy” 2018, nr 56, s. 83.

3 K. Surówka, K. Owsiak, Administrowanie czy rozwój- 20 lat doświadczeń finansowania polskiego samorządu terytorialnego, „Nierówności Społeczne a Wzrost Gospodarczy” 2018, nr 56, s. 33 . 
stopniowe spowolnienie, a następnie od $2018 \mathrm{r}$. ponowny znaczny wzrost ${ }^{4}$. Samorządy zgodnie z ustawa o finansach publicznych, mogą zaciągać kredyty i pożyczki oraz emitować papiery wartościowe. W tej kwestii do końca 2013 r. obowiązywały dwa ilościowe limity zadłużenia lokalnego, a od 2014 r. obowiązywała nowa norma, regulująca limitowanie zadłużenia samorządu, oparta na zindywidualizowanym podejściu do obliczania dopuszczalnego poziomu zadłużenia ${ }^{5}$. Ze względu na charakter tej reguły, przyjęło się określać ją mianem indywidualnego wskaźnika zadłużenia. Wskaźnik ten ${ }^{6}$ zablokował dość skutecznie możliwość zaciągania długu przez niektóre jednostki samorządowe. W efekcie, w 2016 r. wydatki majątkowe zmniejszyły się o 35,5\% w stosunku do 2014 r. ${ }^{7}$, mimo że całkowity dług samorządu wykazywał tendencję wzrostową, zaś tzw. wydatki sztywne w działalności bieżącej, nie uległy poważniejszym modyfikacjom ${ }^{8}$. Mniejsze przyrosty zadłużenia samorządów po 2013 r. można też tłumaczyć zakończeniem okresu kwalifikowalności środków wydawanych w ramach projektów finansowanych ze środków unijnych. Niektóre samorządy odnotowały nawet niewielki spadek wielkości zadłużenia. Najbardziej zadłużone są miasta na prawach powiatu, przy czym część z nich „ukryła” swoje zadłużenie w spółkach komunalnych.

Wprowadzanie kolejnych ograniczeń poziomu deficytu podsektora samorządowego nie rozwiązuje problemu finansów lokalnych. Zadłużenie samorządu nie ma istotnego wpływu na poziom zadłużenia publicznego. Zdecydowanie większy rygor w tym zakresie, powinien obejmować administrację centralną. Udział długu samorządowego w relacji do długu publicznego ogółem jest nieznaczny (na koniec 2016 r. wyniósł 7,2\%, za pierwsze półrocze 2017 r. - 6,9\%) . Deficyt i zadłużenie są zasadne pod warunkiem kontroli ich wysokości i struktury. Tak jak w go-

4 Departament Studiów Makroekonomicznych i Finansów Głównego Urzędu Statystycznego opublikował raport Gospodarka finansowa jednostek samorzq̨du terytorialnego 2018, z którego wynika, że w porównaniu z 2017 r. zadłużenie samorządów wzrosło o ponad 10\%, i jest to pierwszy od 2014 r. notowany wzrost poziomu długu.

5 Od 2019 r. limitem zadłużenia objęte zostały nie tylko typowe instrumenty dłużne (kredyty, pożyczki, obligacje) stosowane przez jednostki samorządowe, ale również wszelkie alternatywne metody finansowania inwestycji samorządowych (np. leasing zwrotny, sprzedaż zwrotna, sprzedaż na raty, subrogacja, factoring). Pomimo zmiany podejścia w zakresie zaliczania różnorodnych zobowiązań do indywidualnego wskaźnika zadłużenia samorządu, w dalszym ciągu pewne możliwości finansowania inwestycji samorządowych pozostaną neutralne dla wskaźnika zadłużenia. Dotyczy to w szczególności zobowiązań z tytułu projektów realizowanych z udziałem środków unijnych, niektóre przedsięwzięcia gospodarcze w ramach spółek publiczno-prywatnych, czy wykorzystanie koncesji na roboty budowlane lub usługi, emisja obligacji przychodowych.

6 Obowiązujący od 1 stycznia 2014 r.

7 W 2016 r. wartość wydatków majątkowych we wszystkich typach jednostek samorządu wyniosta 25,8 mld zt, wobec poziomu ok. 40 mld w 2014 i w 2015 r.

8 Dominują one w wydatkach bieżących i w zależności od typu jednostki samorządowej, stanowią od 60 do $80 \%$ tych wydatków.

9 W niektórych krajach UE (np. Francja, Włochy) nie ustanowiono limitów zadłużania dla samorządów. W Polsce dług komunalny wynosi ok. 5\% PKB, dla przykładu w Niemczech blisko 30\%. 
spodarstwie domowym, uważa się, że w samorządzie nie można wydawać więcej niż go na to stać. Oczywiście, zawsze potrzeby będą większe, niż możliwości ich zaspokojenia, stąd istotne są priorytety w realizacji zadań oraz wybór najefektywniejszych źródeł ich finansowania. Wieloletnie planowanie nie jest gwarancją posiadania środków na inwestycje, lecz jedynie zapisem o takiej możliwości. Organy wykonawcze nie powinny podejmować, pod koniec kadencji, decyzji pociągających za sobą znaczące zobowiązania finansowe, ponieważ spada to na „barki” następców. Władze te powinny być zobowiązane do redukcji istniejącego zadłużenia, aby podjąć na większą skalę zaangażowanie inwestycyjne.

W warunkach prosperity nadmierne zadłużenie jest niemoralne, ponieważ obciążane są nim kolejne władze i kolejne pokolenia, które muszą ponieść koszt z tym związany, nie mając wpływu na wcześniej podjęte decyzje. Sytuacja taka oznacza życie na kredyt i na koszt innych. Wyrażane są przewrotne opinie, że majątek pochodzący $\mathrm{z}$ inwestycji będzie i tak służył przyszłym generacjom, zatem to one powinny ponosić koszty z tym związane. Jest to osąd bezwartościowy, ponieważ majątek ulega naturalnemu zużyciu, a technologie ulegają zmianie. Rygory w postaci wypracowania nadwyżki operacyjnej oraz wyliczenie indywidualnego wskaźnika zadłużenia dla niektórych gmin są trudne do spełnienia. W małych gminach generowane są odpowiednio mniejsze nadwyżki operacyjne, ograniczające możliwości inwestycyjne i wniesienie wkładu własnego do planowanych przedsięwzięć ${ }^{10}$. Wydaje się, że istniejące poprzednio dwa parametry (progi ostrożnościowe) zadłużania samorządu, odnoszące się do poziomu dochodów budżetowych (60\% dochodów i $15 \%$ obsługi długu) były korzystniejsze dla mniej zamożnych wspólnot, mimo że obowiązywanie tych reguł było przedmiotem krytyki praktyków i ekspertów, gdyż brakowało powiązania limitów zadłużenia z sytuacją ekonomiczną i możliwościami spłaty długu samorządu. Mogło to grozić zadłużaniem się ponad faktyczne możliwości spłaty długu, przy jednoczesnym formalnym dotrzymaniu granic zadłużenia.

W ostatnich latach, organy samorządu ponownie decydują się na większe wykorzystanie finansowych źródeł zwrotnych. Głównym powodem zadłużania się samorządu jest nierównowaga budżetowa, będąca konsekwencją nadwyżki zrealizowanych wydatków nad osiągniętymi dochodami w ujęciu rocznym. Dług zaciągany na pokrycie deficytu ma w zdecydowanej większości charakter długoterminowy. Występują też sytuacje, kiedy nie ma deficytu budżetowego lub mamy do czynienia $\mathrm{z}$ równowagą budżetową między dochodami i wydatkami, a jednostka samorządu zadłuża się na spłatę rat, wcześniej zaciągniętego długu. Należy podkreślić, że decyzja o zaciągnięciu długu powinna być przemyślana i szczegółowo przeanalizowana pod kątem całościowego kosztu tego narzędzia. Finansowanie dłużne wymaga rozważnej i proaktywnej polityki fiskalnej, w której koszty i korzyści są

10 Jest to kolejny argument przemawiający dla grupowania mniejszych jednostek samorządowych. W większości małych gmin, transfery z budżetu państwa wynoszą nawet do ok. 7 \% ich dochodów. 
mierzone oraz porównywane indywidualnie dla każdego projektu inwestycyjnego $^{11}$. Realizacja inwestycji, która będzie finansowana m.in. środkami zwrotnymi, wymaga przeprowadzenia rachunku ekonomicznego, pozwalającego zdefiniować finansowe i pozafinansowe koszty oraz korzyści. Według M. Jastrzębskiej, organy samorządu podejmując decyzje o realizacji inwestycji ze środków zwrotnych, powinny opracować wieloletni plan finansowy i wieloletni plan inwestycyjny oraz systematycznie oceniać kondycję finansową, w celu minimalizacji kosztów i ryzyka związanego z użycia instrumentu dłużnego ${ }^{12}$. Władze samorządu stoją zawsze przed wyborem drogi ograniczenia deficytu, czy należy to robić z wykorzystaniem instrumentów dłużnych, czy stosując znaczny wzrost podatków i opłat lokalnych? Jak zauważa Joseph E. Stiglitz, uzasadnieniem zaciągania zobowiązań średnio i długoterminowych jest podejmowanie działalności inwestycyjnej. Natomiast problemem staje się sytuacja, kiedy pożyczki finansują inwestycje, które nie będą zakończone $\mathrm{z}$ różnych powodów ${ }^{13}$.

Ciągłe korzystanie ze zwrotnego finansowania zewnętrznego może spowodować wpadnięcie w tzw. pułapkę (pętlę) zadłużenia, jak też problemy z terminowym regulowaniem zobowiązań. Dalej może to doprowadzić do utraty płynności finansowej. Stąd ważne jest, aby polityka zadłużania się była prowadzona przez władze samorządu racjonalnie i pod kontrolą, a tym samym odpowiedzialnie. Trudności w gospodarce finansowej mogą być zdeterminowane przez wiele czynników, zarówno wewnętrznych (np. nadmierne koszty w działalności bieżącej, „przeinwestowanie”), jak i zewnętrznych (np. zmniejszenie dochodów w wyniku kryzysu gospodarczego, nieprzewidziane wydatki nadzwyczajne $)^{14}$. Istotne są procedury pomiaru długu, pozwalające precyzyjnie zaplanować jego wielkość, czas spłaty i skutek dla budżetu samorządu.

Trzeba zaznaczyć, iż potrzeby finansowe skłaniają niektóre samorządy (głównie gminy) do szukania niestandardowych instrumentów finansowych, nieobciążających indywidualnych wskaźników zadłużenia (np. leasing zwrotny, dzierżawa zwrotna, bądź zadłużanie się w parabankach). W świetle badań K. Kluzy, pogorszenie kondycji finansowej jednostek samorządu na skutek kryzysu zapoczątkowanego w 2008 r., zintensyfikowało poszukiwanie innowacji finansowych ${ }^{15}$. Jak podaje sprawozdanie Krajowej Rady Regionalnych Izb Ob-

11 B. Dafflon, K. Beer-Toth, Managing local public debt in transition countries: An issue of sel$f$-control. Paper prepared for the 14 th Annual Conference of the Networkof Institutions and Schools of Public Administration in Central and Eastern Europe (NISPAcee), Ljubljana, May 11-13, 2006.

12 M. Jastrzębska, Wybór instrumentu zwrotnego finansowania w celu realizacji inwestycji samorządowych, Zeszyty Naukowe Uniwersytetu Szczecińskiego nr 530, Szczecin 2009, s. 52.

13 Joseph E. Stiglitz, Ekonomia sektora publicznego..., s. 947-949.

14 M. Poniatowicz, Dług publiczny w systemie finansowym jednostek samorządu terytorialnego, Wydawnictwo Uniwersytetu w Białymstoku, Białystok 2005.

15 K. Kluza, Zadłużenie jednostek samorządu terytorialnego w Polsce. Trendy historyczne, narzędzia do analizy zdolności spłaty zadłużenia oraz postulaty zmian systemowych, Instytut Rozwoju Miast i Regionów, Warszawa 2019, s. 47-67. 
rachunkowych, korzystanie przez jednostki samorządowe $\mathrm{z}$ innych instrumentów, niż wymienionych w ustawie o finansach publicznych jest jedną z głównych przyczyn problemów gospodarki finansowej samorządu, wymagającej następnie wdrażania programów naprawczych ${ }^{16}$.

Warto w tym miejscu przypomnieć, że organy wykonawcze są zobligowane do informowania o realizacji budżetu. Na tym m.in. polega jawność finansów samorządowych (publicznych). Przy ogólnej analizie oceny finansowej istotne są trzy wielkości: relacja dochodów do wydatków, zadłużenie oraz spłata zobowiązań. W teorii ekonomii zwraca się uwagę, że nadmierne wydatki budżetu „wypychają" inwestycje prywatne, dzięki wzrostowi stopy procentowej, co ujemnie wpływa na inwestycje przedsiębiorców prywatnych ${ }^{17}$. Projekt budżetu samorządu może zakładać jego zrównoważenie (dochody równe wydatkom), nadwyżkę (dochody większe od wydatków) oraz co spotyka się najczęściej - deficyt, kiedy przyjmuje się z góry, że dochody nie pokrywają planowanych wydatków. Najlepszą sytuację stwarzają dwa pierwsze przypadki, a zwłaszcza gdy występuje nadwyżka budżetowa, którą można przeznaczyć $\mathrm{w}$ roku następnym np. na sfinansowanie deficytu.

Zakładany deficyt budżetu samorządu pozwala na realizację większego zakresu zadań, ale trzeba pamiętać, że musi on być sfinansowany. Realnymi źródłami jego pokrycia są wpływy z tytułu: sprzedaży papierów wartościowych, kredytów, pożyczek, prywatyzacji majątku, nadwyżki z lat ubiegłych, wolnych środków jako nadwyżki środków pieniężnych na rachunku bieżącym jednostki (wynikających z rozliczeń wyemitowanych papierów wartościowych, kredytów i pożyczek z lat ubiegłych). W 2009 r. deficyt budżetów samorządów wyniósł 11,5 mld zł przy równoczesnym przeznaczeniu na inwestycje $42,1 \mathrm{mld}$ zł, w tym finansowane ze środków UE. Do 2012 r. (włącznie) przyrost zadłużenia samorządu był dynamiczny, zaś od 2013 r. tempo zmian spadało, przy czym zadłużenie w miastach na prawach powiatu nadal wzrastało (tabela 7). Wśród jednostek samorządowych największe zadłużenie wystąpiło $\mathrm{w}$ miastach na prawach powiatu, następnie $\mathrm{w}$ pozostałych gminach, potem w powiatach i województwach. Wraz ze wzrostem zadłużenia zwiększała się obsługa długu do 2012 r., po tym okresie wielkość obsługi ulegała stopniowemu zmniejszeniu. Tendencję tę można tłumaczyć relacjami jednostek samorządowych z systemem bankowym.

Intensywna polityka inwestycyjna i zadłużanie się w latach 2008-2013 spowodowały wyczerpanie możliwości dalszego dynamicznego zaciągania zobowiązań długoterminowych. Odpowiednio niższe zapotrzebowanie na środki zwrotne mogły znaleźć odzwierciedlenie w oferowaniu przez banki atrakcyjniejszych produktów finansowych. Interesujące informacje przynosi wskaźnik obsługi długu do wielkości zadłużenia. W skrajnych latach objętych analizą, kształtował się

16 Krajowa Rady Regionalnych Izb Obrachunkowych, Sprawozdanie z działalności regionalnych izb obrachunkowych i wykonania budżetu przez jednostki samorządu terytorialnego w 2015 r., Warszawa 2016.

17 R. Milewski (red.), Podstawy ekonomii, Wydawnictwo Naukowe PWN, Warszawa 1998, s. 444. 
on kolejno: w gminach od 4,58 do $2,47 \%$, w miastach na prawach powiatu 4,81-2,39\%, w powiatach 6,35-2,74\%, zaś w województwach 3,99-2,32\%. W środkowym horyzoncie badania (2012) wskaźniki te były nieco wyższe od początkowego stanu i kształtowały się: w gminach na poziomie 5,35\%, w miastach na prawach powiatu $4,96 \%$, w powiatach $5,71 \%$, w województwach $4,62 \%$, co potwierdza wcześniejsze przypuszczenie.

$\mathrm{Z}$ miast na prawach powiatu najbardziej zadłużone są duże miasta (relacja do dochodów ogółem), które dysponują największymi budżetami ${ }^{18}$. Z danych Ministerstwa Finansów wynika, że najbardziej zadłużonym miastem jest Warszawa, na koniec 2017 r. gmina miała dług na poziomie $5 \mathrm{mld} 126 \mathrm{mln} \mathrm{zł}$. Na drugim miejscu w tym rankingu jest Łódź, która musi spłacić dług w wysokości 2 mld $685 \mathrm{mln}$ zł. Kolejnymi miastami w tym niechlubnym rankingu są: Wrocław - dług sięgający 2 mld 674 mln zł, Kraków 2 mld 309 mln zł, Lublin 1 mld 330 mln zł, Poznań 1 mld 228 mln zł, Bydgoszcz 1 mld 026 mln zł. Jednak faktyczne zadłużenie w tych samorządach jest wyższe, gdyż należy uwzględnić zobowiązania długoterminowe przejmowane przez spółki komunalne. Zagadnienie zadłużenia spółek komunalnych jest najmniej rozpoznane w gospodarce finansowej samorządu. Główna uwaga jego władz oraz organów nadzorczych skupiona jest na kwestii długu dotyczącego sfery budżetu, podczas gdy równolegle występuje zjawisko powstawania zadłużenia w spółkach komunalnych. W wielu dużych miastach, długi spółek komunalnych nie są podawane do publicznej wiadomości (np. Wrocław, Gdańsk, Poznań, Łódź, Warszawa), a władze tych spółek niechętnie podają te informacje (a nawet blokują). Długi te regulowane są przez samorząd (jako ich właściciela), a w rzeczywistości przez mieszkańców. Realnym zagrożeniem dla finansów samorządowych są zobowiązania jednostek posiadających osobowość prawną, nadzorowanych przez samorządy (instytucje kultury, samodzielne publiczne zakłady opieki zdrowotnej). Jeśli są one likwidowane, przekształcane lub znajdują się w złej sytuacji finansowej, wówczas ich zadłużenie przejmuje (bądź uczestniczy w pokrywaniu strat) nadzorująca jednostka samorządowa ${ }^{19}$.

Powstawanie długu publicznego, będącego skumulowanym deficytem budżetowym ma głęboki wymiar społeczny. Często ponoszone zobowiązania mają relatywnie długą perspektywę czasową ich regulowania, zatem faktycznie obciążeni są długiem publicznym następcy i kolejne pokolenia. Wobec tego społecznym uzasadnieniem jest pozyskanie miarodajnej opinii mieszkańców, odnośnie określonych tytułów dłużnych (na ogół na duże inwestycje, przedsięwzięcia) oraz pełna komunikacja pomiędzy władzą i administracją samorządową a mieszkańcami, którzy w rezultacie będą obarczeni obowiązkiem spłaty owego długu. W przypadkach wątpliwych, dyskusyjnych (rozbieżnych stanowisk), nie

18 Występują nieliczne odstępstwa związane z zaciąganiem zobowiązań finansowych np. w parabankach. W takich przypadkach wielkość długu drastycznie wzrasta w relacji do dochodów budżetu (była gmina Ostrowice, gmina Słupsk).

19 E. Ruśkowski, Finanse samorządu regionalnego i lokalnego, [w:] Gospodarka regionalna i lokalna, Wydawnictwo Naukowe PWN, Warszawa 2008, s. 264. 
można wykluczyć uruchomienia demokratycznej instytucji referendum, którą najlepiej jest zastosować przy akceptacji wizji (strategii) rozwoju jednostki samorządowej proponowanej przez ich władze.

$\mathrm{Na}$ zarządzających gospodarką komunalną spoczywa trud działania zgodnego z kanonami sztuki ekonomicznej, czyli podejmowania decyzji racjonalnych, z uwzględnieniem efektywności. Także w tym wyraża się profesjonalizacja kierowania sprawami publicznymi $\mathrm{w}$ samorządzie $\mathrm{z}$ użyciem pieniędzy mieszkańców. W wielu krajach znajduje to oparcie w silnej świadomości podatkowej i celowości wydawania środków publicznych. $\mathrm{Na}$ większe wydatki i powstający deficyt, istotny wpływ mogą mieć zdarzenia losowe lub niewłaściwa, czy beztroska polityka wydatkowa organów samorządowych ${ }^{20}$. Powszechnym imperatywem powinien być klimat oszczędności, presja na eliminowanie wszelkiego marnotrawstwa i niegospodarności. Mieszkaniec wspólnoty samorządowej jest nie tylko wyborcą, konsumentem usług, ale też podatnikiem (tax payer) oczekującym, że pieniądze (z jego udziałem) przeznaczone na cele publiczne będą dobrze zagospodarowane ${ }^{21}$. W Polsce wymóg ten jasno określa art. 44 ust. 3 ustawy o finansach publicznych. Wydatki powinny być dokonywane w sposób celowy i oszczędny, umożliwiający terminową realizację zadań oraz w wysokości i w terminach, wynikających z wcześniej zaciągniętych zobowiązań. Dla celowości i oszczędności przyjęto dwie zasady: uzyskiwanie najlepszych efektów z danych nakładów oraz optymalnego doboru metod i środków służących osiąganiu założonych celów. Łatwo zauważyć, że zasady te nawiązują do wcześniej opisanej zasady racjonalnego gospodarowania, w aspekcie jej wydajności oraz oszczędności. W praktycznym ujęciu, najlepsze efekty z nakładów polegają na uzyskiwaniu najlepszej (największej) wartości z zaangażowanych zasobów. Powstaje tutaj zasadnicze pytanie, czy można jednocześnie maksymalizować efekty i minimalizować nakłady finansowe? Teoretycznie wydaje się to niemożliwe, ponieważ występuje działanie w przeciwnych kierunkach. W praktyce jest to realne, jeśli istnieją niewykorzystane rezerwy zasobów (zdolności produkcyjno-usługowych).

20 A. Miszczuk, M. Miszczuk, K. Żuk, Gospodarka samorzqdu terytorialnego, Wydawnictwo Naukowe PWN, Warszawa 2007, s. 103.

21 W mieście Bonn (USA) istnieje w dokumentacji komunalnej zapis, że „zarówno wybrani, jak i zatrudnieni powinni być cały czas świadomi, że ich pozycja zależy od podatników, którzy zasłużyli na to, aby ich podatki były uczciwie używane i w określonej formie do nich wrócity". 


\section{Rozdział XI}

\section{Kadencyjność organów a planowanie spłaty dtugu w czasie}

Przejawem samodzielności jednostek samorządu jest m.in. dostęp do rynku kapitałowego. Samorząd może poszukiwać zewnętrznych źródeł finansowania w postaci środków zwrotnych. Jak zaznaczono, złota reguła finansów publicznych powinna odnosić się wyłącznie do działalności bieżącej. Jeśli mamy do czynienia z działalnością inwestycyjną korzystanie z instrumentów dłużnych jest uzasadnione i często wskazane. Paradoksalnie można powiedzieć, że odniesienie się tej reguły do finansów publicznych, w tym lokalnych, ogranicza możliwości rozwoju i hamuje wysiłek inwestycyjny. Szczególne znaczenie ma to w warunkach kryzysów gospodarczych i finansowych, wywołujących spadek zainteresowania przedsięwzięciami inwestycyjnymi. Należy w tym miejscu odwołać się do instrumentów pobudzających aktywność gospodarczą w koncepcji interwencjonizmu publicznego J. M. Keynes’a, który wskazał, że równowaga gospodarki nie jest stała i na ogół występuje $\mathrm{w}$ warunkach niepełnego wykorzystania zdolności produkcyjnych. Jak zauważa S. Owsiak, stanowi to konsekwencję niesprawności mechanizmów rynkowych, w tym niskiej skłonności do inwestowania ${ }^{1}$. W sytuacji kryzysowej znalazły się również polskie samorządy, które chcą jeszcze wykorzystać szanse pozyskania bezzwrotnej pomocy finansowej m.in. z UE.

W gospodarce samorządu, źródłami finansowania zadań publicznych jest zaciąganie zobowiązań krótko, średnio i długoterminowych. Z punktu widzenia kadencyjności władz samorządu, podejmowanie decyzji, które rodzą skutki finansowe $\mathrm{w}$ dłuższym czasie (powyżej pięciu lat) wymaga szczególnej uwagi, $\mathrm{z}$ trzech powodów. Pierwszy, ze względu na długi horyzont czasowy planowania finansowego występuje duże ryzyko nierealności osiągnięcia zamierzonych wielkości dochodów (w niepewnym otoczeniu), co pociąga za sobą możliwość wystąpienia utraty płynności finansowej, zanik działalności inwestycyjnej, preferowanie działalności bieżącej, a w jej ramach świadczenie usług o niższej jakości itp. Drugim

1 S. Owsiak, Finanse publiczne. Teoria i praktyka, Wydawnictwo Naukowe PWN, Warszawa 2017, s. 55. 
powodem jest wyższy koszt obsługi spłaty zobowiązania długoterminowego (długu). Przepisy prawa wprawdzie nie zabraniają podejmowania tego typu ryzykownego i kosztownego zobowiązania, bowiem uzależniają jedynie zaciąganie długu od wielkości dopuszczalnego wskaźnika zadłużenia. Trzecim powodem jest przerzucanie ciężaru konsekwencji podjętych decyzji finansowych na barki przyszłych władz i pokoleń.

Problemem ekonomicznym, na który rzadko zwraca się uwagę jest korelacja długości sprawowania władzy $\mathrm{w}$ samorządzie $\mathrm{z}$ horyzontem czasowym zaciągania i regulowania zobowiązań długookresowych. Zagadnienie to wywołuje szereg dysfunkcji w procesie gospodarowania zasobami finansowymi, rzutujących następnie na poziom efektywności ekonomicznej struktur samorządowych. Organy samorządu funkcjonują cyklicznie w ramach określonego czasu, wyznaczającego kadencję ich działania. Organy stanowiące i wykonawcze samorządu działały w kadencji czteroletniej do 2018 r., natomiast następne kadencje zostały wydłużone do pięciu lat. Istotnym rozwiązaniem prawnym, dotyczącym organu wykonawczego w gminie jest możliwość sprawowania władzy jedynie w dwóch kolejnych kadencjach.

Kolejną dysfunkcją jest koszt obsługi zadłużenia. W ostatnim czasie obserwuje się dość częste zjawisko odkładania spłaty zaciąganych zobowiązań na dalsze lata. Zjawisko to polega na zaciągnięciu długu w danym roku, zaś planowane rozpoczęcie jego spłaty dopiero po 3-5 latach. Przesunięcie w czasie finansowania zobowiązania długoterminowego rodzi dwie ujemne konsekwencje. Pierwszą jest wzrost kosztów obsługi długu, czyli wzrost kosztów działalności bieżącej. Drugą - jest odroczenie spłaty na długi czas powodujące, że zastosowane narzędzie (źródła finansowania) jest drogie i mało efektywne. Może okazać się, że uzyskane w wyniku inwestycji efekty rzeczowe będą niewspółmiernie mniejsze w stosunku do poniesionych nakładów. Pomija się w ten sposób analizę efektywności przedsięwzięcia inwestycyjnego, która może wykazać, że założony efekt został osiągnięty nadmiernym kosztem finansowym. Późne rozpoczynanie spłaty rat pożyczonego kapitału powoduje jej przesunięcie na kolejną kadencję, w której finansami samorządowymi będą zarządzać nowe władze.

Przyczyna dysfunkcji w gospodarce finansowej samorządu tkwi m.in. w sferze polityczno-ekonomicznej działania jego władz. Problem polega na właściwej identyfikacji rzeczywistego zapotrzebowania społecznego na dobra i usługi publiczne, a następnie ustalenia hierarchii najpilniejszych potrzeb. Tymczasem wiele samorządów stosuje inną sekwencję postępowania, dotyczącą najpierw poszukiwania potencjalnych źródeł finansowania przedsięwzięć inwestycyjnych, a dopiero potem dostosowanie ich do faktycznych potrzeb mieszkańców wspólnoty, z uwzględnieniem planów strategicznych. Takie działanie rodzi dwie konsekwencje. Po pierwsze, postępowanie nosi charakter spektakularny i pozytywny jako wyraz dużej aktywności organu wykonawczego wraz z podległą administracją, w pozyskiwaniu środków zewnętrznych. Druga konsekwencja nosi wymiar negatywny, ponieważ powstały majątek (środki trwałe) w wyniku realizacji inwestycji będzie wymagał odpowiednich nakładów finansowych na jego utrzymanie. 
Wzrost kosztów działalności bieżącej wpływa na wypracowanie się mniejszej nadwyżki operacyjnej. Dodatkowo, druga konsekwencja wiąże się z kosztem niezaspokajania realnych potrzeb społecznych, rzutujących na jakość życia mieszkańców wspólnoty.

Presja na aktywne zdobywanie środków zewnętrznych przesłania tym samym, dokonywanie racjonalnych wyborów w zakresie potrzeb inwestycyjnych, kształtowanych według priorytetów rozwojowych. Istnieje niewielka świadomość, że podjęcie wysiłku inwestycyjnego finansowanego środkami własnymi i zewnętrznymi wpływa na konieczność ponoszenia związanych z tym kosztów, nie tylko przez obecnych mieszkańców, ale często przyszłych pokoleń. Związek wydatków z kadencyjnością władz samorządu uwypukla M. Możdżeń stwierdzając, że „jeśli prawdopodobieństwo ponownego wyboru dotychczasowych rzadzacych jest mniejsze niż jeden, nie będa oni w petni brali pod uwage konsekwencji swoich decyzji $w$ długim okresie, przerzucając część kosztów podjętych decyzji politycznych na swoich następców"2. Pozytywem dla mieszkańców wspólnoty jest wtedy możliwość korzystania ze zrealizowanych inwestycji. Tym niemniej, obciążanie nadmiernym długiem w danej kadencji powinno łączyć się z regulowaniem wcześniej zaciągniętych zobowiązań długoterminowych. W przeciwnym razie, wystąpi zbyt duża konsolidacja zobowiązań dłużnych. Zasadą powinno być nierozkładanie spłaty rat pożyczonego kapitału w długim okresie czasu³ ${ }^{3}$ Odpowiedzialność za zaciąganie długoterminowych zobowiązań finansowych staje się tym bardziej istotna w świetle wprowadzonej dwukadencyjności organu wykonawczego w gminie.

Stąd też można sformułować wniosek, że punktem wyjścia w działalności rozwojowej jest rzetelna diagnoza potrzeb inwestycyjnych w oparciu o kryteria ekonomiczne i aprobatę społeczną. W samorządzie obserwuje się często zaangażowanie inwestycyjne w przedsięwzięcia gospodarcze, bez przedstawienia wymiernych efektów gospodarczych i społecznych, korzystnych dla mieszkańców samorządu. Rodzi to już przesłanki do podjęcia decyzji nieracjonalnych. Wyższy poziom inwestycji może wynikać z cyklu politycznego, określonego przez cykl wyborczy ${ }^{4}$ Szczególnie duży rozmach inwestycyjny obserwuje się pod koniec kadencji, gdy osoba sprawująca urząd wójta, burmistrza, prezydenta miasta ma zamiar ponownie kandydować. Analogiczna sytuacja występuje na początku następnej kadencji, kiedy organ wykonawczy wdraża w życie obietnice wynikające z programu (obietnic) wyborczego.

Pewną dysfunkcją są też budżety obywatelskie (partycypacyjne) jako forma współzarządzania w samorządzie. Niezrozumiała była nowelizacja ustawy o samorządzie gminnym, wprowadzająca obligatoryjność budżetu obywatelskiego

2 M. Możdżeń, Instytucje polityczne i proces budżetowy. Przeciwdziałanie tragedii wspólnych zasobów fiskalnych, Wydawnictwo Naukowe Scholar, Warszawa 2018, s. 37.

3 Przykładem tego jest zaciąganie przez gminy wiejskie (np. Dalików, Pęczniew) zobowiązań długoterminowych (w wysokości 170-230 tys.) i planowanie ich spłaty w okresie 12-15 lat.

4 E. Markowska-Bzducha, Rola samorzqdu terytorialnego w kreowaniu rozwoju lokalnego i regionalnego - samorzqdowe wydatki inwestycyjne, Prace Naukowe Uniwersytetu Ekonomicznego we Wrocławiu, nr 101, Wrocław 2010, s. 259. 
w miastach na prawach powiatu. Budżet ten, jako narzędzie polityki samorządowej, powinien być fakultatywny, sporządzany na miarę potrzeb zgłaszanych przez mieszkańców i możliwości finansowych. Z ekonomicznego punktu widzenia, forma budżetu obywatelskiego wprowadzona w polskich samorządach jest dowodem na nieefektywne gospodarowanie środkami budżetowymi ze względu na:

- wykonywanie pewnych prac należących do zakresu bieżącego utrzymania obiektów infrastrukturalnych (np. naprawa chodnika, ustawienie koszy, ławek itp.),

- realizowanie inwestycji o małym zakresie rzeczowym, z uwagi na jednoroczny cykl, w którym trzeba zlecić opracowanie dokumentacji projektowej i wykonać roboty budowlane,

- zgłaszanie projektów budzących wątpliwości natury funkcjonalnej i estetycznej, popieranych przez niewielką grupę osób,

- koszt obsługi administracyjnej procedury tego budżetu.

Budżet obywatelski ma jedyne uzasadnienie, jeżeli będzie traktowany jako koszt działania demokracji lokalnej. Rozwój samorządu polega m.in. na aktywnym uczestnictwie mieszkańców w życiu społecznym i gospodarczym. Nowoczesny samorząd tworzony jest przez społeczeństwo obywatelskie, zainteresowane i żywo reagujące na zachodzące zmiany gospodarcze i społeczne. Aktywność obywatelska obejmuje różne formy, począwszy od sygnalizowania problemów, potrzeb, poprzez podejmowanie inicjatyw w zakresie realizacji zadań samorządu, aż do współuczestnictwa w zarządzaniu sprawami publicznymi. Dzięki temu kontrola społeczna nabiera pełniejszego wymiaru, wywołując presję na władzach samorządu. Stąd też, do rozważenia pozostają następujące propozycje rozwiązania podniesionego problemu:

- ograniczenie zadłużenia w danej kadencji do określonej wysokości,

- brak możliwości odkładania spłaty zaciąganych zobowiązań na dalsze lata.

Dzięki limitowi zadłużania w kadencji nieblokowane są możliwości realizacji inwestycji podejmowanych przez nowe władze samorządu. Ma to znaczenie po nowelizacji przepisów prawa, ograniczających możliwość działania organu wykonawczego w gminie tylko w dwóch kolejnych kadencjach (10 lat). Intensywne zadłużanie w danej kadencji oznacza wydłużenie okresu spłaty na bardzo odległy czas (nawet do 25 lat). Jak słusznie zauważył K. Kluza, od pewnego czasu samorządy zaczęły stosować długie okresy karencji w spłacie pożyczonego kapitału. Karencje w spłacie kapitału były rzadkim zjawiskiem i zwykle nie przekraczały jednego roku, a obecnie można powiedzieć, że stały się praktyką ${ }^{5}$.

W tym miejscu można doznać podwójnego odczucia. Po pierwsze, znaczny wzrost zadłużenia $\mathrm{w}$ kadencji może być postrzegany jako wyraz dużej aktywności inwestycyjnej, co należy ocenić pozytywnie. Z drugiej jednak strony, przeniesienie spłaty zadłużenie na długi okres czasu, w którym obecny organ

5 K. Kluza, Wpływ zmian w ustawie o finansach publicznych na koszt finansowania samorządów, „Zarządzanie i Finanse” 2013, nr 3, s. 216. 
wykonawczy nie będzie sprawował już władzy, należy ocenić negatywnie. Wywiera to wpływ na kształtowanie się kondycji finansowej jednostki samorządowej w następnych okresach, bowiem może powstać sytuacja bardzo ograniczonych środków finansowych, pozwalających jedynie na prowadzenie działalności bieżącej i spłatę wcześniej zaciągniętych zobowiązań. W ten sposób zanikają szanse kontynuowania polityki inwestycyjnej przez nowe władze samorządu. Ograniczenie funkcjonowania władz do dwóch kadencji (co wydaje się słuszne) powoduje brak odpowiedzialności za sytuację finansową w latach spłaty zadłużenia. W amerykańskiej myśli ekonomicznej ugruntowany jest pogląd, że dla zwiększonych inwestycji, z których korzyści będą dopiero $\mathrm{w}$ przyszłości, racjonalnym sposobem finansowania jest zadłużenie, ponieważ teraźniejsi podatnicy subsydiują przyszłych użytkowników, co rzutuje ujemnie na efektywność i sprawiedliwość. Mocno podkreślane jest, iż okres spłaty długu powinien zawierać się w okresie pobierania korzyści z danej inwestycji 6 .

6 Michael E. Bell [w:] Lester M. Salamon, Robert A. Seidel, P. Bury, T. Markowski, Gospodarka samorządów terytorialnych w świetle doświadczeń amerykańskich, Fundacja Promocji Czystych Technologii TECHEKO, Łódź 1995, s. 83-84. 



\section{Rozdział XII}

\section{Diagnoza sytuacji finansowej jednostek samorządowych}

System prawny określa ramy, zasady i mechanizmy gospodarowania środkami publicznymi w samorządzie. Mówiąc inaczej, reguluje on od strony formalno-prawnej wszelkie działania, związane z gospodarowaniem zasobami finansowymi w samorządzie. Od reaktywacji samorządu w Polsce (1990 r.) system prawny, określający ekonomiczny układ funkcjonowania jego jednostek ulegał licznym zmianom. Sytuacja finansowa samorządu odzwierciedla faktyczny i aktualny stan jego gospodarki finansowej. To, co się dzieje w sferze procesów realnych gospodarki samorządu, znajduje następnie odbicie w kondycji finansowej. Na przebieg procesów i zjawisk w gospodarce finansowej samorządu wpływają czynniki o charakterze zewnętrznym i wewnętrznym. Czynnikami zewnętrznymi o największej sile oddziaływania są:

- koniunktura i sytuacja na rynkach światowych,

- polityka gospodarcza państwa i jej efekty,

- przepisy prawa i ich zmiany,

- wpływ rynku finansowego.

Z kolei czynnikami tkwiącymi wewnątrz samorządu są:

- charakter rynku lokalnego,

- zarządzanie organów samorządu i wzajemne relacje,

- potencjał ludnościowy i procesy demograficzne,

- stan, wielkość i struktura majątku komunalnego,

- wysiłek inwestycyjny,

- uwarunkowania naturalne,

- jakość administracji samorządowej.

Identyfikacja podstawowych zjawisk i problemów zachodzących w gospodarce finansowej samorządu oraz interpretacja i ocena ich zależności leży u podstaw określenia istniejącego stanu. Mówiąc inaczej, dokonywana jest w ten sposób diagnoza sytuacji finansowej jednostki samorządu, dostarczająca wiedzy o zdolności samorządu do ponoszenia kosztów działalności bieżącej oraz możliwości finansowania działań rozwojowych. Na ogół diagnoza stanowi przesłankę dla przeprowadzenia zmian w mechanizmie finansowania gospodarki samorządowej. 
Potencjał finansowy każdego podmiotu gospodarczego zakreśla ramy podjęcia różnej aktywności gospodarczej, niezależnie od przyjętych celów. Zwrócenie szczególnej uwagi na potencjał finansowy tkwiący w małych samorządach znajduje uzasadnienie w ich wielkościach. Małe samorządy są na ogół niewielkimi jednostkami prawno-administracyjnymi, obejmującymi gminy wiejskie, miejskie (miasteczka) oraz niektóre powiaty. Kryterium określenia wielkości takich samorządów jest nieostre i wydzielenie ich dokonywane jest na podstawie niewielkiej liczby ludności do ok. 10-15 tys. Mały powiat może odznaczać samorząd grupujący 3-4 gminy o łącznej liczbie mieszkańców do ok. 21 tys. Z punktu widzenia finansów istotniejsze znaczenie posiada potencjał ludnościowy, niż powierzchnia jednostki samorządowej. Liczba mieszkańców jako kluczowy parametr, niezależnie od ich aktywności gospodarczej, wpływa pośrednio na strumienie dochodów i wydatków budżetowych. Wpływ ten może być bieżący, jak i przyszłościowy, zarówno w krótkim, średnim, jak i w długim horyzoncie czasowym.

Oceniając potencjał finansowy małych samorządów przez pryzmat ludności i jej struktury, należy zatem prześledzić trzy następujące po sobie efekty ekonomiczne, stanowiące skutek zachodzących procesów demograficznych. Pierwszym efektem, ujmowanym aktualnie jest ukształtowanie się określonej liczby i struktury mieszkańców, w przekroju płci oraz wieku. Ze struktury wiekowej ludności wynika liczebność i skład grupy mieszkańców w wieku produkcyjnym. Grupa ta jest najważniejsza dla gromadzenia dochodów własnych w budżecie samorządu. Znajdują się w niej pracownicy, przedsiębiorcy, inwestorzy, odprowadzający podatki dochodowe (PIT, CIT), które w części wpływają do budżetu jednostki samorządowej i stanowią główne źródło dochodów własnych ${ }^{1}$. Niektórzy z nich uiszczają jeszcze inne podatki i opłaty lokalne, takie jak np. podatek od nieruchomości, od środków transportowych. Wiele podatków i opłat lokalnych ma charakter marginalny i nie stanowi znaczącego dochodu własnego samorządu (np. podatek leśny, opłata od posiadania psów). Drugim efektem dotyczącym przyszłości jest liczba mieszkańców kończących proces edukacyjny, która w krótkim czasie (2-3 lata) podejmie aktywność gospodarczą. Z kolei, trzecim efektem jest zbiorowość małych i młodych mieszkańców, znajdujących się na początku i w trakcie nauczania. Czwartym efektem jest obserwacja kształtowania się grupy ludności najstarszej w samorządzie. Wymienione przekroje odzwierciedlają strukturę potrzeb poszczególnych grup ludności.

Sytuacja finansowa samorządu obrazuje jego kondycję w celu racjonalnego gospodarowania środkami budżetowymi, a tym samym wyraża zdolność do finansowania (wykonywania) zadań własnych. Punktem wyjścia dla przeprowadzenia oceny sytuacji finansowej jest analiza działalności bieżącej (operacyjnej). W tym obszarze, realizowane sązadania publiczne przez świadczenie usług komunalnych, absorbujących większość środków budżetu. W działalności bieżącej występuje

1 W przypadku gminy, udział podatku dochodowego od osób fizycznych w budżecie stanowi ok. $38 \%$, zaś w powiecie ok. $10 \%$. 
eksploatacja majątku komunalnego, jako podstawa wykonywania zadań własnych. Działalność bieżąca jest komplementarna i substytucyjna wobec działalności inwestycyjnej. Komplementarność oznacza, że działalność bieżąca stanowi przesłankę uruchomienia inwestycji, gdyż potrzeby z tym związane wynikają ze stopnia zużycia ekonomicznego i technicznego składników majątkowych oraz podjęcia nowych przedsięwzięć gospodarczych. Substytucyjność tych działalności dotyczy decyzji organów samorządu o przeznaczeniu proporcjonalnym, określonej puli środków finansowych, należących do domeny polityki lokalnej.

Przywiązanie szczególnej uwagi do działalności bieżącej podyktowane jest dwoma powodami. Po pierwsze, działalność ta odbywa się w rygorach nakazujących oszczędne gospodarowanie. Po drugie, w działalności eksploatacyjnej generowane są już środki, które mają finansować koszty inwestycji. Obserwacje i analizy wskazują, że to w tej działalności tkwią duże rezerwy potencjału produkcyjno-usługowego, obniżające poziom efektywności ekonomicznej. W samorządach występują też zróżnicowane relacje między działalnością bieżącą i inwestycyjną. W praktyce istnieją samorządy, których władze skupiają główną uwagę na działalności bieżącej, przypominającej bardziej administrowanie. Słaba aktywność w działalności inwestycyjnej może doprowadzić (nawet w jednej kadencji) do degradacji mająt$\mathrm{ku}$ komunalnego ${ }^{2}$. Świadczy to o braku polityk branżowych w danym samorządzie, a tym samym pozwala przypuszczać, że wydatkowanie środków finansowych nie wynika ze strategicznych planów rozwoju (programów gospodarczych). Z kolei w samorządach, w których punkt ciężkości przesuwa się na intensywną działalność inwestycyjną, ich władze prowadzą politykę nadmiernego zadłużania jednostki. Wydaje się, że z ekonomicznego punktu widzenia, zbyt ekspansywna polityka inwestycyjna prowadzi do ponoszenia bardzo wysokich kosztów. Wobec tego, niezbędne jest uwzględnienie w działalności inwestycyjnej, spowolnienia w dynamice przedsięwzięć rozwojowych (odtworzeniowych, modernizacyjnych), które są atrakcyjne ze względów marketingowych. Stąd wywodzi się potrzeba racjonalnych decyzji (na miarę możliwości) w zakresie planowania wieloletniego (strategicznego) według hierarchii potrzeb społecznych i technicznych.

Dla oceny efektywnościowej stanu finansów niezbędne jest wykorzystanie analizy ekonomicznej. Skuteczne zarządzanie finansami wymaga zgromadzenia informacji opisujących gospodarkę samorządu. Informacje te są potrzebne w procesie decyzyjnym, w którym bierze udział wielu uczestników, $\mathrm{z}$ władzami na czele. $\mathrm{W}$ analizie ekonomicznej znaczące miejsce zajmuje analiza finansowa, dotycząca rejestracji i oceny gospodarki środkami publicznymi w celu realizacji zadań publicznych. Analiza finansowa spełnia w samorządzie następujące funkcje:

2 Przykładowo, w samorządach, gdzie istnieje zorganizowana komunikacja publiczna, brak inwestycji w infrastrukturę przewozową może doprowadzić do zagrożenia bezpieczeństwa świadczenia tej usługi. Ilustracją jest Łódź, gdzie zły stan taboru został zrekompensowany zakupem wysłużonych już pojazdów tramwajowych z Niemiec. Natomiast zaniedbanie w innych składnikach infrastruktury może skutkować licznymi awariami, powodującymi przerwy w świadczeniu usług. 
- służy diagnozowaniu gospodarki finansowej, jako narzędzie oceny działalności ekonomicznej i finansowej,

- jest instrumentem oceny racjonalności wykorzystania środków publicznych,

- stanowi podstawę podejmowania decyzji,

- zapobiega nieprawidłowościom lub koryguje bieżący przebieg procesów gospodarowania (funkcja antycypacyjna).

Analiza finansowa w samorządzie ma zastosowanie w dwóch sferach procesów gospodarczych:

- regulacyjno-zarządzającej dla potrzeb organów i administracji komunalnej,

- realnych, występujących w podmiotach bezpośrednio świadczących usługi publiczne.

Dzięki analizie finansowej możliwe jest badanie kondycji (sytuacji) finansowej, informującej o sprawności działania władz, według kryterium: skuteczności, gospodarności i efektywności. Stan finansów samorządu wyraża potencjał jego rozwoju gospodarczego. Istnieje związek między sytuacją finansową samorządu a jego efektywnością. Poprawa efektywności gospodarowania wpływa na polepszenie sytuacji finansowej, która $\mathrm{z}$ drugiej strony tworzy warunki dla dynamizacji tej pierwszej. Najbardziej popularną metodą pomiaru i oceny kondycji finansowej jest analiza wskaźnikowa. Jest ona zwykle przeprowadzana na dwóch poziomach:

- strony dochodów i wydatków w budżecie,

- równowagi finansowej, płynności, zdolności kredytowej i zadłużenia.

Badając stronę dochodową w budżecie, standardowo wyodrębnia się następujące przekroje analizy funkcjonalnej:

- dochody według źródeł (dochody własne i transfery zewnętrzne w postaci subwencji ogólnej i dotacji celowych oraz bieżące i majątkowe),

- strukturę dochodów własnych ze uwzględnieniem dochodów podatkowych i majątkowych.

Obserwacja sfery dochodowej poza oceną efektywności (wydajności) źródeł dochodów, pozwala ocenić samodzielność samorządu w tym zakresie oraz skalę władztwa podatkowego organów samorządu. Proces wydatkowania środków finansowych odbywa się formalnie z zachowaniem dyscypliny budżetowej. Dzięki analizie finansowej możliwe jest zdobycie wiedzy niezbędnej dla wyboru wieloletniego wariantu zadłużenia, określenia dopuszczalnego i bezpiecznego zadłużenia w przyszłości oraz oceny długofalowych skutków budżetowych obsługi zadłużenia ${ }^{3}$.

Kluczowym parametrem $\mathrm{w}$ ocenie sytuacji finansowej samorządu jest wymieniona już kategoria nadwyżki operacyjnej, ilustrująca zdolność do podejmowania i realizacji nowych przedsięwzięć inwestycyjnych - tak bezpośrednio jak pośrednio przez spłacanie wcześniej zaciągniętych zobowiązań. Nadwyżka operacyjna obrazuje coś więcej, niż sam formalny wynik działalności bieżącej, gdyż

3 P. Dziekański, Analiza sytuacji finansowej samorzqdu jako wyznacznik efektywności ekonomicznej jednostek samorządu terytorialnego, [w: Finanse publiczne i rozwój przedsiębiorczości w regionach (red.) B. Filipiak, Wydawnictwo Wyższej Szkoły Bankowej w Poznaniu, Poznań 2011, s. 252. 
obejmuje również nadwyżkę budżetową $\mathrm{z}$ poprzednich lat oraz wolne środki. Kształtowanie się nadwyżki operacyjnej jest badane przez pryzmat strony dochodowej i wydatkowej budżetu. Saldo budżetu w części dochodowej i wydatkowej może ukazywać: deficyt, nadwyżkę lub równowagę budżetu, a zadłużenie obejmujące sumę zobowiązań jednostki samorządowej. Dla syntetycznej analizy stanu gospodarki finansowej samorządu można przyjąć według autorki następujące warianty służące ocenie ogólnej:

- zła sytuacja finansowa,

- stabilna sytuacja finansowa,

- dobra sytuacja finansowa.

Tabela 3. Ocena kondycji gospodarki finansowej jednostki samorządowej

\begin{tabular}{|c|c|}
\hline Stan sytuacji finansowej & Kryteria oceny \\
\hline Zła & $\begin{array}{l}\text { spadek dochodów budżetowych, niski poziom dochodów } \\
\text { (ok. } 3 \text { tys. zł per capita), mały udział dochodów własnych, ni- } \\
\text { ski udział nadwyżki operacyjnej w dochodach budżetowych, } \\
\text { niska relacja wyniku na działalności bieżącej wraz z dochodami } \\
\text { majątkowymi do wydatków majątkowych, występowanie przez } \\
\text { okres } 3 \text { lat dużego deficytu budżetowego (ujemny wynik finan- } \\
\text { sowy), wysoki i rosnący poziom zadłużenia, wysoki koszt obsługi } \\
\text { zadłużenia, relatywnie niski udział wydatków inwestycyjnych } \\
\text { (mniej niż 10\% wydatków budżetowych), ryzyko utraty płynności } \\
\text { finansowej i zdolności kredytowej. }\end{array}$ \\
\hline Stabilna & $\begin{array}{l}\text { nie ma istotnego zagrożenia utraty płynności finansowej, } \\
\text { a wielkość zadłużenia kształtuje się na bezpiecznym poziomie } \\
\text { (ok. } 40 \% \text { dochodów budżetowych). Wydatki majątkowe plasu- } \\
\text { ją się w przedziale } 10-20 \% \text { wydatków w budżecie. }\end{array}$ \\
\hline Dobra & $\begin{array}{l}\text { dochody sukcesywnie wzrastają, występuje cyklicznie nadwyżka } \\
\text { budżetowa*, zadłużenie jest umiarkowane (do 30\% docho- } \\
\text { dów budżetowych) i pozostaje pod kontrolą, występuje znaczący } \\
\text { udział wydatków inwestycyjnych w budżecie (powyżej 20\%) } \\
\text { pozwalający na podjęcie dużych zamierzeń rozwojowych. }\end{array}$ \\
\hline
\end{tabular}

* Z punktu widzenia efektywnościowego, występowanie corocznie nadwyżki budżetowej jest niekorzystne. Może to świadczyć o bardzo ograniczonej działalności inwestycyjnej, ponieważ na działalności bieżącej musi od 2011 r. występować wynik dodatni. Mając na względzie możliwość korzystania ze środków UE oraz duże potrzeby w zakresie poprawy warunków bytowych (poprzez m.in. rozbudowę infrastruktury technicznej i społecznej), nieskorzystanie z takiej szansy może ilustrować bierne podejście władz gminnych w procesie zarządzania, skupiając się bardziej na administrowaniu sprawami publicznymi.

Źródto: opracowanie własne.

W pierwszym wariancie, kondycja finansowa jednostki jest niekorzystna ekonomicznie i wymaga gruntownej zmiany. W wariancie drugim, cechą sytuacji 
finansowej jest oscylowanie relacji wydatków i dochodów wokół zera, podobnie jak wyniku finansowego. Sytuację $\mathrm{w}$ wariancie trzecim charakteryzują parametry finansowe kształtujące się odwrotne do wymienionych w wariancie pierwszym. W ocenie finansowej istotne są trzy kategorie, które odnoszą się do wielkości dochodów ogółem i dochodów własnych. Udział nadwyżki operacyjnej w dochodach ogółem świadczy o reżimie w wydatkach bieżących. Sytuacja jest korzystna, jeżeli wskaźnik ten wzrasta, a jego szybki wzrost dowodzi stosowania ostrych rygorów w działalności operacyjnej. Udział nadwyżki operacyjnej i dochodów majątkowych w dochodach ogółem informuje o własnych możliwościach finansowania inwestycji. Sytuacja jest lepsza, im wyższa jest wartość tego wskaźnika. W gminach wiejskich wskaźnik ten kształtuje się na poziomie $30-40 \%$. Następny udział tych kategorii w wydatkach majątkowych informuje o faktycznym sfinansowaniu wydatków majątkowych środkami własnymi. Jeżeli wielkość wskaźnika przekracza 100\%, oznacza to nadwyżkę, która pozwala na przeznaczenie jej na częściową spłatę zadłużenia, a budżet wtedy nie jest deficytowy.

Wskaźnik udziału deficytu w wydatkach majątkowych ukazuje niedobór środków finansowych i konieczność poszukiwania źródeł sfinansowania tego niedoboru (zwykle ze środków zwrotnych lub przez prywatyzację majątku komunalnego). W gminach wiejskich istnieją raczej małe możliwości sfinansowania deficytu ze środków pochodzących ze sprzedaży majątku komunalnego, ze względu na jego zakres i strukturę. Ich władze mogą prowadzić bardzo ostrożną, lub często zmienianą politykę w zakresie zaciągania zobowiązań długoterminowych (dłużnych). W związku z tym należy obserwować wysokość zadłużenia w dochodach ogółem i dochodach własnych. Sytuacja jest dobra, jeśli udziały te kształtują się na najniższym poziomie. Władze mogą realizować zadania publiczne przez działalność oszczędną i pełną wyrzeczeń, podejmując określone wyzwania, przy zachowaniu rygorów budżetowych. Niektóre władze są powściągliwe i ostrożne w zadłużaniu, a potrzeby inwestycyjne realizują według zasady racjonalności (nie ponad stan) - co wiąże się z dużą samodyscypliną w działalności bieżącej. Dobrze jeśli po latach dużego wysiłku inwestycyjnego, następuje pewne „spowolnienie” w celu spłaty zadłużenia i przygotowania się do poniesienia ponownego wysiłku inwestycyjnego. Postępująca w wielu samorządach depopulacja prowadzi do poważnych konsekwencji społecznych i ekonomicznych. Mniej ludności oznacza nie tylko spadek popytu na usługi komunalne, ale również uszczuplenie dochodów. W stosunku do liczby mieszkańców, może oznaczać nadmiar zdolności produkcyjno-usługowych urządzeń infrastrukturalnych, które należy utrzymywać w dobrym stanie technicznym, sanitarnym, odpowiadającym ustawowym normom bezpieczeństwa. Jest to zagadnienie zasadnicze $\mathrm{w}$ polityce samorządowej, ponieważ wiąże się $\mathrm{z}$ ustaleniem priorytetów rozwojowych i preferencji w podejmowaniu różnych typów działalności gospodarczej.

Wiele gmin ma poważne problemy finansowe. Niedobór środków pieniężnych oraz wysokie zadłużenie powodują, że z jednej strony władze starają się ograniczyć 
wydatki, a z drugiej - zwiększyć dochody budżetowe. Działania w zakresie zmniejszenia wydatków polegają m.in. na;

- likwidacji szkół (np. w Warszawie, w Łodzi, w Częstochowie, w Opolu),

- likwidacji straży miejskiej (choć zdarza się, iż decyzja ta nie tylko podyktowana jest względami ekonomicznymi, ale też społecznymi - mieszkańcy postulują o likwidację straży),

- oszczędzaniu na oświetleniu ulic (np. w Krakowie, w Chełmie, próbowano również w Łodzi),

- zwalnianiu urzędników (Ruda Śląska) bądź „zamrożeniu” ich wynagrodzeń (np. Łódź).

Oprócz wymienionych działań, władze lokalne podejmują jeszcze wiele innych decyzji, w celu ograniczenia wydatków budżetowych. Do najbardziej popularnych należy likwidacja innych jednostek organizacyjnych (poza szkołami i strażami) - np. zakładów budżetowych, przedszkoli itp. Gminy chcąc zwiększyć dochody budżetowe podwyższają opłaty i podatki lokalne ${ }^{4}$.

Istotne miejsce w gospodarce i w polityce finansowej samorządu zajmuje ustalanie cen (opłat, taryf), które wpływają na wydatki gospodarstw domowych. Jak wynika z badań, wydatki na usługi komunalne w strukturze wydatków mieszkańców gmin są znaczące i wynoszą ok. 1/3 wydatków ogółem, podczas gdy średnia w Europie wynosi ok. 25\% ${ }^{5}$. Wobec tego, jednym z czynników wpływających na konkurencyjność samorządu, w sensie ekonomicznym, jest poziom opłat oferowanych usług komunalnych przez samorządy. Ustawodawca przyznał radzie gminy (miejskiej), powiatu oraz sejmikowi województwa prawo do określenia wysokości cen i opłat za usługi komunalne o charakterze użyteczności publicznej, jak też za korzystanie z obiektów i urządzeń użyteczności publicznej. Władze samorządu mogą też formalnie uregulować sposób, w jaki ustalane będą ceny i opłaty lokalne, obowiązujące na ich terenie. Delegacje do stanowienia tego rodzaju przepisów miejscowych (w drodze uchwał) zawarto m.in. w treści ustawy o gospodarce komunalnej ${ }^{6}$. Polityka władz lokalnych przez proces zarządzania ma zapewnić dostępność odbiorców do podaży usług, w sensie przestrzennym i ekonomicznym. Dostępność przestrzenna usług komunalnych stanowi pochodną polityki inwestycyjnej władz gminy. O dostępności ekonomicznej usług decyduje natomiast poziom cen, ustalany przez organy gminy i zainteresowane podmioty gospodarcze (wykonujące zadania publiczne).

Między polityką inwestycyjną a polityką cenową zachodzi istotna zależność, polegająca na tym, że wydatki inwestycyjne na budowę lub rozbudowę urządzeń

4 B. Filipiak, Strategia podatkowa władz samorzqdowych jako czynnik stymulujący rozwój lokalny, [w:] Przestrzeń w nowych realiach gospodarczych, (red.) S. Korenik, P. Hajduga, M. Rogowska, Prace Naukowe Uniwersytetu Ekonomicznego we Wrocławiu nr 408, Wrocław 2015, s. 77-78.

5 Z. Grzymała (red.), Wydatki na usługi komunalne w strukturze wydatków mieszkańców gmin - ocena w układzie regionalnym, Oficyna Wydawnicza Szkoła Główna Handlowa w Warszawie, Warszawa 2015, s. 76-78.

6 Art. 4 ust. 1 pkt 2 ustawy z dnia 20 grudnia 1996 r. o gospodarce komunalnej... 
infrastruktury technicznej znajdują odbicie (lub nie) w procedurze określania poziomu cen na usługi komunalne. Polityka cenowa samorządu w zakresie usług komunalnych - $\mathrm{w}$ przeciwieństwie do przedsiębiorstwa rynkowego - pozostaje pod przemożnym wpływem czynników społecznych i ekonomicznych (czasami także politycznych). Problem polega na zharmonizowaniu racji politycznych i efektywnościowych w ustalaniu ceny na usługi komunalne.

Realizowana przez samorząd gospodarka komunalna, niezależnie od formy organizacyjno-prawnej, nie powinna być nastawiona na osiąganie maksymalnych zysków, lecz przede wszystkim na zaspokajaniu potrzeb mieszkańców wspólnoty samorządowej. Ceny niektórych usług są ustalane przez organ stanowiący samorządu, przy dużym udziale organu wykonawczego i administracji, która również uczestniczy w tym procesie ${ }^{7}$. Przy ich określaniu ścierają się dwie racje: ekonomiczna i społeczna. Trudna sytuacja finansowa mieszkańców (wysokie bezrobocie, niskie wynagrodzenia, duża liczba emerytów i rencistów o niskich dochodach) powinny być uwzględniane przy ustalaniu cen za usługi komunalne. W praktyce poziom tych cen wystarcza często na pokrycie jedynie wydatków bieżących. Stosowanie różnych ulg, zwolnień lub umorzeń w opłatach za usługi komunalne przekształca się w formę pomocy społecznej. Takie działania zmniejszają wpływy środków finansowych w budżetach samorządowych, ale z punktu widzenia mieszkańca jest to korzystne.

30 lat doświadczeń krajowego rynku usług komunalnych pozwala stwierdzić, że podstawową cechą usługi komunalnej jest jej powszechność. Oznacza to, że samorządy nie powinny dążyć do zarabiania na usługach komunalnych - albowiem nie chodzi o zysk z ich dostarczania, czy też udostępniania. Ideą działania przedsiębiorstw komunalnych jest bilansowanie swoich wydatków i potrzeb w ramach rachunku ekonomicznego. Oczywiście mogą one, a nawet powinny wypracować zysk - jednakże jego przeznaczeniem jest wsparcie rozwoju, jakości i powszechności świadczonych usług. Na rynku usług komunalnych tego typu rozwiązania mają charakter prosocjalny i doskonale się sprawdzają.

Ustalania poziomu cen za niektóre usługi komunalne nie regulują żadne przepisy ogólnokrajowe, które ujednoliciłyby zasady kalkulowania opłat. Dotyczy to m.in.: opłaty za wykup miejsc na cmentarzach i usługi cmentarne, opłaty za bilety wstępu, opłaty za udostępnianie boisk lub hal sportowych administrowanych przez samorząd. Kalkulacje tych opłat zawierają różne pozycje (koszty) ${ }^{8}$. W praktyce powoduje to, że występują znaczące różnice w wysokości opłat za daną usługę komunalną . Nie ulega wątpliwości, iż poziom cen za usługi lokalne powinien być

7 Można nawet powiedzieć, że ten proces rozpoczyna.

8 Przykładowo, ustalając opłatę cmentarną każda gmina uwzględnia inne składniki kosztów, tj. jedni biorą pod uwagę tylko koszty utrzymania cmentarza, inni doliczają jeszcze jednorazową opłatę za wodę, a jeszcze inna grupa gmin nie uwzględnia tego rodzaju opłat jako składnika dwudziestoletniej opłaty za miejsce pochówku.

9 Na przykład, całkowity koszt miejsca grzebalnego za dwuosobowy grób na okres 20 lat w Luboniu (woj. wielkopolskie) wynosit 255 zt, a w Koninie (też woj. wielkopolskie) - 1980 zł. 
zróżnicowany i uzależniony od indywidualnych uwarunkowań samorządu, niemniej niejednorodny sposób kalkulacji opłat (ujmowanie w opłacie różnorakich składników kosztów) powoduje, że mieszkańcy narażeni są na ponoszenie nieuzasadnionych wydatków. Kalkulowanie wysokości stawek opłat za usługi związane np. $z$ zaopatrzeniem $w$ wodę oraz odprowadzaniem i oczyszczaniem nieczystości ciekłych, jest zadaniem bardzo odpowiedzialnym i złożonym. Z jednej strony, powinny zostać tak skalkulowane, aby odbiorcy tych usług (gospodarstwa domowe, przedsiębiorstwa) byli w stanie je pokryć, z drugiej zaś powinny zapewnić podmiotowi realizującemu usługę, zwrot wszystkich kosztów związanych z prowadzoną przez niego działalnością.

Opłaty za odbiór i gospodarowanie odpadów komunalnych powinny pokrywać koszty świadczonych usług, uwzględniające bieżące koszty operacyjne, koszty utrzymania i konserwacji, jak również koszty związane z przyszłymi inwestycjami. W praktyce, procedura ustalania cen rozpoczyna się od zidentyfikowania rocznych kosztów eksploatacji, obsługi i utrzymania obiektów, jak również wielkości poniesionych nakładów inwestycyjnych, dokonania projekcji kosztów zamknięcia i rekultywacji składowiska, z przeniesieniem i podziałem tych kosztów na poszczególne lata oraz zapewnieniem środków na wymianę maszyn i urządzeń. Gmina jako organizator zbiorowego transportu publicznego może też kształtować poziom cen za usługi przewozowe realizowane na jej obszarze. Wysokość cen za usługi przewozowe w publicznym transporcie zbiorowym stanowi materię niezwykle wrażliwą społecznie. Zakres, jakość oraz dostępność usług zbiorowego transportu publicznego, przesądza o stopniu mobilności mieszkańców gminy, stanowiąc wyznacznik jej rozwoju.

Przy wyborze sposobu naliczania opłat za usługi komunalne - i ściśle z tym związaną kwestię oszacowania ceny jednostkowej za świadczone usługi - osoby, jak i podmioty (przedsiębiorstwa) odpowiedzialne za te kalkulacje spotykają się z naciskami, aby ze względów politycznych utrzymywać ceny na jak najniższym poziomie (np. w roku wyborczym), bądź aby szacunki uwzględniały pewne rezerwy środków, które będą przeznaczone na przedsięwzięcia inwestycyjne. Ustalanie zaniżonych stawek opłat za świadczone usługi komunalne, prowadzi do takich konsekwencji jak:

- zmniejszenie liczby inwestycji, co może prowadzić do szybszej degradacji stanu technicznego majątku (sieci, urządzeń), zwiększenia liczby awarii i wynikających stąd kosztów utrzymania,

- dodatkowe obciążenia budżetów samorządów, wynikające z pokrywania różnic pomiędzy ceną skalkulowaną za daną usługę, a ceną ustaloną przez ich władze.

Trudności finansowe mieszkańców, jak też relatywnie wysokie bezrobocie są powodem ustalania cen za usługi komunalne na poziomie, który często wystarcza jedynie na pokrycie wydatków bieżących.

Znaczna część samorządów podjęła nadmierny wysiłek inwestycyjny (przeinwestowała), z udziałem funduszy unijnych, zadłużając się na inwestycje, które były niezbędne $\mathrm{w}$ ich infrastrukturze. Uzasadnia to potrzebę zasilania budżetu 
przez wpływy pochodzące m.in. ze sprzedaży majątku komunalnego. W mniejszych samorządach są to jednorazowe źródła pozyskania dodatkowych środków do budżetu. Jednak, jeżeli pozbycie się części majątku komunalnego ma być „receptą" na wyjście ze złej sytuacji finansowej, aby „uratować” jednostkę samorządową przed zlikwidowaniem, to można się na to zgodzić. Warto jednak najpierw spróbować innego modelu, jakim jest zwiększenie podatków lokalnych i podwyższenie opłat taryfowych. Trzeba pamiętać, że infrastruktura raz sprzedana, jest niezwykle trudna do odzyskania. Należy przy tym rozważyć, czy ogólne koszty zmniejszenia zadłużenia związane ze sprzedażą majątku komunalnego będą niższe od ogólnych kosztów społecznych zwiększenia obciążeń podatkowych i taryfowych $\mathrm{w}$ danej perspektywie czasowej oraz o ile niższe będą obciążenia od prawdopodobnych podwyżek nowego właściciela?

Decyzja o ustaleniu poziomu opłaty komunalnej jest złożona i trudna z punktu widzenia decydenta (zarządzającego). Ceny większości usług komunalnych są ustalane przez organ stanowiący samorządu. Mimo że ostateczna decyzja w tym zakresie podejmowana jest w sposób zbiorowy, to większa rola i odpowiedzialność spada na organ wykonawczy ${ }^{10}$. Istotny udział $\mathrm{w}$ procesie decyzyjnym $\mathrm{w}$ zakresie ustalania opłat lokalnych odgrywa wyspecjalizowany aparat administracyjny (urząd). W pewnej mierze, wpływ na ten proces ma bezpośredni wykonawca usług świadczonych $\mathrm{w}$ ramach określonych zadań gminy. Jak ukazują nieliczne opracowania, poziom opłat za świadczone usługi komunalne jest w Polsce zróżnicowany ${ }^{11}$. Nasuwa się wniosek, że w różnych częściach kraju akceptuje się różne poziomy, czy wysokości opłat. Można stwierdzić, iż w zależności od samorządu i regionu mamy do czynienia $\mathrm{z}$ różnym progiem akceptowalności społecznej poziomu opłat za usługi komunalne dla ludności ${ }^{12}$. Podnoszone są również ceny biletów komunikacji miejskiej, opłaty za wodę i ścieki, ciepło, za parkowanie, podatek od nieruchomości (ustalany na maksymalnym poziomie określonym przez ustawodawcę), podatek od środków transportowych, opłata miejscowa ${ }^{13}$. Coraz więcej gmin podejmuje działania związane $\mathrm{z}$ prywatyzacją (sprzedażą) swojego mająt$\mathrm{ku}^{14}$, choć nie zawsze wiąże się to ze stabilizacją sytuacji finansowej samorządu. Można odnieść wrażenie, że głównym motywem sprzedaży jest cel fiskalny (zwiększenie dochodów lub przychodów budżetu).

10 Decyzja zapada na dwóch poziomach władzy lokalnej: stanowiącej (rady) i wykonawczej (wójt, burmistrz, prezydent miasta).

11 Z. Grzymała (red.), Wydatki na usługi komunalne w strukturze wydatków mieszkańców gmin - ocena w układzie regionalnym, Oficyna Wydawnicza Szkoła Główna Handlowa w Warszawie, Warszawa 2015.

12 Wyższe opłaty za przedszkola wprowadzono m.in. w Łodzi, we Wrocławiu, zaś wzrost czynszu w mieszkaniach komunalnych - w Gdańsku, Łodzi, Słupsku.

13 Niektóre miasta wprowadziły opłaty od tzw. deszczówki (Wrocław, Koszalin).

14 Na przykład Czeladź - sprzedaż mieszkań komunalnych, Warszawa, Poznań - sprzedaż spółek komunalnych, nieudana próba prywatyzacji Zakładu Wodociągów i Kanalizacji w Łodzi. 
Niewątpliwie jedną z zasad, którą powinni kierować się rządzący - zarówno organ wykonawczy (odpowiedzialny za przygotowanie projektu budżetu), jak i stanowiący (uchwalający budżet) - jest, by nie wydać więcej niż stać samorząd. Dążenie do zrównoważonego budżetu jest o tyle istotne, że nie zadłużamy przyszłych pokoleń. Warto jednak podkreślić, że istnienie samorządu ma sens, gdy posiada on samodzielność finansową. Prawie każda decyzja podjęta w samorządzie rodzi konsekwencje finansowe. Zmniejszający się udział dochodów własnych w budżetach powoduje, iż autonomia finansowa tych jednostek maleje $\mathrm{e}^{15}$. Dobrą sytuację finansową mają tylko te gminy, w których znajdują się np. kopalnie i elektrownie (tak jak Kleszczów - najbogatsza gmina w Polsce) bądź pełnią rolę tzw. sypialni dużych miast, albo są atrakcyjne turystycznie. Wtedy udział dochodów własnych w budżecie jest relatywnie wysoki - zdecydowanie powyżej 55\%. Niestety takich samorządów jest w Polsce niewiele, a trzeba pamiętać, że to właśnie wysokość dochodów własnych w dużej mierze decyduje o zdolności samorządu do realizacji zadań własnych, a to z kolei wpływa na jakość życia mieszkańców.

Część dużych miast w Polsce sygnalizuje problem niedoboru środków finansowych na realizację zadań publicznych. Twierdzą one, że prowadzi to do ograniczania wielkości świadczonych usług oraz do pogorszenia ich jakości. Za sprawcę tego stanu rzeczy wskazują decyzje rządowe, które ich zdaniem, zmniejszają źródła dochodów własnych. Dodatkowo, jak już stwierdzono, od kilku lat podnoszony jest problem niedoszacowania subwencji ogólnej w części oświatowej, jak też niedoszacowanie dotacji celowych na zadania zlecone. W ten sposób powstają niedobory w finansowaniu zadań zleconych, zadań związanych z oświatą oraz pozostałych zadań własnych. W związku z tym, formułowana jest opinia o ograniczeniu samodzielności finansowej (dochodowej) samorządów.

Problem, o którym mowa, jest bardziej złożony i wymaga jego analizy w kontekście wielu uwarunkowań oraz zasad polityki finansowej. Obserwacja kształtowania się budżetów samorządu wskazuje, że dysponują one coraz większymi dochodami, a przypadku gmin dochodami zwiększonymi o fundusze z budżetu państwa na tzw. Program 500 plus. Według szacunków środki z tego tytułu kształtują się na poziomie 10-20\% ogółu dochodów. Z reguły, na wielkość dochodów własnych budżetu, istotny wpływ mają wpływy z tytułu udziału w podatku od osób fizycznych (PIT) - silnie zależne od koniunktury gospodarczej oraz wpływy z podatku od nieruchomości, których wielkość kształtowana jest przez organy gminy. Oceniając stan faktyczny pozyskanych dochodów w gminach, należy dochody budżetowe pomniejszyć o przekazane środki w ramach Programu 500 plus. Decyzje rządowe o podniesieniu wysokości płacy minimalnej, obniżenia najniższej stawki podatkowej (z 18 na 17\%) oraz zwolnienia młodych osób (do 26 lat) z podatku dochodowego, wpływają na sytuację finansową samorządu po stronie dochodów, a następnie wydatków. $Z$ przedstawionych danych wynika, że dochody budżetu

15 W latach 2008-2009 dochody własne stanowity w budżetach jednostek samorządowych ponad $50 \%$. 
samorządu wykazują tendencję rosnącą wyrażoną kwotowo, natomiast inaczej sytuacja kształtuje się w przypadku ich struktury. W budżetach samorządów obserwuje się spadek udziału dochodów własnych na rzecz dotacji celowych, przy zachowaniu dość stabilnego udziału subwencji ogólnej (tabela 4 i 5 w załączniku).

W świetle zmienionych regulacji prawnych, samorządy mogą rekompensować stratę finansową innymi źródłami zasilania budżetu, takimi jak: fundusz sołecki (dofinansowanie z budżetu państwa z 50 do 80\%), pozyskanie środków z różnych programów wsparcia (np. mieszkalnictwo, rewitalizacja), fundusze celowe. Nade wszystko, władze samorządowe muszą koncentrować uwagę na racjonalizacji swojej działalności poprzez oszczędną działalność bieżącą i politykę inwestycyjną opartą o uzasadnione priorytety rozwojowe. Tłumaczenie i opinie wielu władz samorządowych (zwłaszcza dużych miast) nie do końca są trafne i przekonujące, ponieważ $\mathrm{w}$ wielu $\mathrm{z}$ nich realizowane są przedsięwzięcia przynoszące nikłe korzyści społeczne lub ekonomiczne. Działania te prowadzone są pod presją wizerunkowej polityki gospodarczej, przynosząc w efekcie niegospodarność, a często marnotrawstwo zasobów finansowych. Wskazane byłoby obligatoryjne wprowadzenie instrumentu efektywnościowego w postaci budżetu zadaniowego dla miast na prawach powiatu. Miasta te dysponują odpowiednio większym budżetem, którego gospodarka jest mniej transparentna i jawna.

Należy podkreślić, że największe rezerwy gospodarcze istnieją w działalności bieżącej, pochłaniającej dominującą część środków budżetowych. Samo zestawienie nakładów finansowych na zadania bieżące w poszczególnych klasyfikacjach budżetowych, w układzie planowania i wykonania (wyrażonego kwotowo i procentowo) nie odzwierciedla planowanych oraz osiągniętych efektów rzeczowych. W działalności bieżącej, w "gąszczu” klasyfikacji budżetowej, łatwo jest ukryć (głównie w dużych miastach) pewne wydatki, niekonieczne celowe i uzasadnione ekonomicznie oraz społecznie ${ }^{16}$. Takiej wiedzy nie posiadają radni (tym bardziej mieszkańcy), którzy często bezkrytycznie pozytywnie oceniają wykonanie budżetu przez organ wykonawczy, udzielając tym samym absolutorium dla niego (asymetria informacji). Szczegółowe informacje w zakresie wydatkowania środków budżetu w ramach działalności bieżącej można pozyskać jedynie przez dostęp do dowodów księgowych (faktur, rachunków).

W praktyce, najczęściej dane o nieprawidłowościach w wykorzystaniu środków budżetowych przez samorządy, można otrzymać z wyników kontroli zewnętrznych (rio, NIK), które jednak nie zawsze są zamieszczane na stronach internetowych samorządu. W działalności samorządu zbyt często korzysta się z usług zewnętrznych, które potem nie są wykorzystywane w działalności bieżącej, bądź służą tylko ograniczonej liczbie urzędników w wątpliwym celu ${ }^{17}$. Monitorowanie dochodów i wydatków bieżących jest bardzo istotne, ponieważ przez oszczędną

16 Na przykład, dotyczące zakupu różnych usług, przez liczne komórki organizacyjnych urzędu i jednostki budżetowe miasta.

17 Chodzi tu o ekspertyzy, opinie, analizy, podróże służbowe, produkty promocyjne, wyposażenie pomieszczeń (biur) w zbędne urządzenia typu: telewizory, lodówki, fotele i kanapy. 
gospodarkę można wygenerować określoną wielkość nadwyżki operacyjnej. Natomiast $\mathrm{w}$ działalności inwestycyjnej realny zakres niegospodarności jest odpowiednio mniejszy. Wynika to z powstania efektów, w postaci konkretnych środków trwałych, posiadających określoną wartość wytwórczą i zakres rzeczowy. Dzięki temu możliwe jest przeprowadzenie analizy porównawczej o charakterze efektywnościowym w stosunku do składnika majątku, zarówno na etapie planowania jak i wykonania. 



\section{Rozdział XIII}

\section{Planowanie dtugofalowe. Wieloletnia prognoza finansowa}

Planowanie wieloletnie uznawane jest w literaturze przedmiotu za niezbędny instrument nowoczesnego zarządzania publicznego, $w$ tym zarządzania finansami publicznymi. Jest procesem permanentnego zadawania pytań dotyczących przewidywanego stanu jednostki, jej otoczenia oraz gospodarki $\mathrm{w}$ przyszłości ${ }^{1}$. Pod względem strukturalnym, plan wieloletni jest zbliżony do programu działania w dłuższym horyzoncie czasowym. Planowanie długofalowe jest procesem podejmowania decyzji w obszarze, wyznaczania celów i określania sposobów ich osiągania w konkretnym horyzoncie czasowym, przy uwzględnieniu skutków finansowych podjętych działań ${ }^{2}$. Uwzględniając fakt, iż budżet samorządu (jak też państwa), jest dokumentem jednorocznym, to powinien być oparty o długofalowe planowanie. Można powiedzieć, że wieloletnie planowanie jest czymś niezbędnym, komplementarnym w stosunku do dokumentu operacyjnego - budżetu. Działalność rozwojowa wymaga powiązania wydatków ze średnio i długookresowymi celami oraz z kondycją finansową w dłuższej perspektywie (w tym zarządzanie długiem). Wielkości budżetowe obrazujące sytuację jednostki samorządowej w przyszłych latach, pozwalają na dokonywanie analizy i oceny możliwości finansowych do podejmowania wyzwań inwestycyjnych, jak i często z tym łączonej, zdolności kredytowej.

Od 2010 r. system planowania długofalowego w gospodarce finansowej samorządu opiera się na wieloletniej prognozie finansowej (WPF), która wraz z budżetem stanowi podstawowe, obligatoryjne ${ }^{3}$ dokumenty finansowe każdej jednostki ${ }^{4}$.

1 B. Richardson, R. Richardson, Business Planning. An Approach to Strategic Management, PITMAN Publishing, London 1992, s. 2.

2 M. Dylewski, Planowanie budżetowe w podsektorze samorządowym. Uwarunkowania, procedury, modele, Wydawnictwo Difin, Warszawa 2007, s. 60; J. Bogdanienko, Zarys koncepcji, metod i problemów zarządzania, Dom Organizatora, Toruń 2020, s. 191.

3 Prognoza nie jest dokumentem obowiązkowym, jeśli jednostka samorządowa nie posiada długu, bądź nie realizuje zadań wieloletnich - co w praktyce raczej jest zjawiskiem niewystępującym.

4 Formalny status WPF wynika z zapisów ustawy z dnia 27 sierpnia 2009 r. o finansach publicznych... 
Wymienione dokumenty, oprócz spełnienia kryterium legalności, stanowią przejaw przejrzystości finansów publicznych ${ }^{5}$. W świetle przepisów prawa, WPF obejmuje okres roku budżetowego oraz co najmniej, trzech kolejnych lat. Jednakże okres objęty tym dokumentem nie może być krótszy niż czas, na jaki przyjęto limity wydatków, określone dla każdego planowanego przedsięwzięcia. Częścią WPF jest też prognoza długu, sporządzona na okres, na który zaciągnięto i planuje się zaciągnąć nowe zobowiązania. Zdaniem L. Patrzałka, prognoza jest opisem zamierzonych, w perspektywie co najmniej trzech lat, wewnętrznie spójnych działań organów samorządu, związanych z gromadzeniem i rozdysponowaniem zasobów pieniężnych $\mathrm{w}$ świetle osiągania wyznaczonych celów, związanych $\mathrm{z}$ organizowaniem oraz udostępnianiem dóbr publicznych i społecznych ${ }^{6}$. Należy dodać, że na poziomie państwa wprowadzono obowiązek opracowania wieloletniego planu finansowego państwa (WPFP). Jest to dokument, obejmujący tylko cztery lata, a dane w nim zawarte stanowią bazę do przygotowania projektu budżetu państwa na kolejny rok ${ }^{7}$. Widać $\mathrm{z}$ tego kilka niekonsekwencji w podejściu do planowania wieloletniego na poziomie państwa i samorządu.

Pierwszą niekonsekwencją jest przyjęcie różnych rozwiązań w obszarze horyzontu czasowego objętego tym planowaniem (WPFP - 4 lata, WPF - minimum 4 lata). Drugą niekonsekwencją jest przyjęcie różnych nazw dla podobnych dokumentów: „plan” dla państwa, „prognoza” dla samorządu (zatem charakter prawny WPF jest jedynie prognostyczny) ${ }^{8}$. Kolejną niekonsekwencją jest brak zapisu $\mathrm{w}$ ustawie o finansach publicznych, zgodnie z którym WPF stanowiłoby podstawę przygotowania budżetu jednostki samorządowej (takie podejście zastosowano w przypadku WPFP). Odnośnie samorządu postanowiono, że wartości przyjęte $\mathrm{w}$ prognozie i w budżecie powinny być zgodne, co najmniej w zakresie wyniku budżetu, przychodów i rozchodów oraz w zakresie wielkości długu9. W rezultacie takiego stanu rzeczy, potencjalnie mogłoby się okazać, że plany te są konkurencyjne i stanowią źródło sprzeczności pomiędzy uchwałami dotyczącymi planów finansowych. W różnych częściach WPFP znajdują się też rozproszone in-

5 M. Dylewski, Problemy wykorzystywania WPF w zarządzaniu finansami jednostki samorzadu terytorialnego, Studia Ekonomiczne, Zeszyty Naukowe Uniwersytetu Ekonomicznego w Katowicach nr 273, Katowice 2016, s. 51.

6 L. Patrzałek, Finanse samorządu terytorialnego, Wydawnictwo Uniwersytetu Ekonomicznego we Wrocławiu, Wrocław 2010, s. 116-117.

7 Art. 105 ust. 1 ustawy z dnia 27 sierpnia 2009 r. o finansach publicznych...

8 Pojęcia „plan” i „prognoza” nie są synonimami. Plan - jest określeniem sposobu postępowania, jest programem działań, zaś prognoza - jest przewidywaniem procesów od nas niezależnych. Plan oceniany jest z punktu widzenia efektywności i skutków uzyskiwanych dzięki tym działaniom, natomiast prognoza oceniana jest jedynie z punktu widzenia jej trafności i niesie za sobą ryzyka, stąd konieczność stosowania tzw. zasady ograniczonego zaufania. Prognozowanie i planowanie są ze sobą w procesie zarządzania, jednak nie należy je ze sobą utożsamiać; E. Sobol, Nowy słownik języka polskiego, Wydawnictwo Naukowe PWN, Warszawa 2002, s. 666 i 753.

9 Art. 229 ustawy z dnia 27 sierpnia 2009 r. o finansach publicznych... 
formacje o podsektorze samorządowym i kontroli deficytu oraz długu samorzą$\mathrm{du}$, co nie pozwala na zrozumiałe przedstawienie jego kondycji finansowej. Stąd wskazane byłoby wprowadzenie do WPFP wyodrębnionego obszaru poświęconemu samorządowi, jako tej części sektora finansów publicznych, która odpowiada za większość inwestycji w kraju.

Wieloletnie prognozy finansowe stanowią podstawowe źródło informacji o planowanych przez poszczególne samorządy, kategoriach finansowych (w tym zaciągniętego i planowanego do zaciągnięcia długu) na najbliższe lata. Zbiór elementów (parametrów liczbowych), który powinien być uwzględniony w treści prognozy jest relatywnie rozbudowany ${ }^{10}$. Biorąc pod uwagę fakt, że w praktyce dane w WPF projektuje się dla okresu dłuższego niż cztery lata, szczegółowość prognozy zwiększa się, bowiem czas ten wydłuża się ze względu na przedsięwzięcia wieloletnie oraz prognozę spłaty długu. Nadmierna, rozbudowana w czasie, szczegółowość prognozy jest (w opinii autorki) jedną z kluczowych i podstawowych wad konstrukcyjnych tego dokumentu. L. Hanus wskazuje, że zgodnie z ogólnymi zasadami prognozowania, lepiej sprawdzaja się prognozy mniejszej ilości, większych $i$ ważnych kategorii - nadmierne uszczegótowienie prognozy, jedynie zwiększa ilość pracy do wykonania, nie zwiększając przydatności i realności prognozy ${ }^{11}$. Szeroki zakres danych finansowych determinuje wiele innych problemów, m.in. takich jak: zbyt częste zmiany prognozy (liczne zmiany w budżecie skutkują niemal równie licznymi zmianami w prognozie), czy też realistyczność prognozy. Trzeba podkreślić, że ustawodawca nadał WPF kilka ważnych cech, do których zaliczyć trzeba: realistyczność, kroczący charakter i ciągłość obowiązywania.

Pomimo że w przepisach prawa wskazano na minimalny zakres zgodności prognozy i rocznego budżetu, to w praktyce każda większa zmiana uchwały budżetowej pociąga za sobą jednoczesną nowelizację prognozy. W efekcie WPF może podlegać nawet kilkunastokrotnym modyfikacjom w trakcie roku budżetowego. Można zatem mówić o swego rodzaju dostosowania treści prognozy do budżetu $\mathrm{w}$ związku $\mathrm{z}$ dokonywanymi zmianami. W ten sposób dokument strategiczny (wieloletni) staje się wtórny w stosunku do dokumentu operacyjnego (jednorocznego), jakim jest budżet. Ze względu na swoją istotę, WPF powinna stanowić ramy dla budżetu samorządu, który powinien być de facto jej uszczegółowieniem i instrumentem realizacji - choć nie wynika to wprost z przepisów prawa. Wprawdzie ustawodawca $\mathrm{w}$ art. 229 ustawy o finansach publicznych ustanawia minimalny zakres zgodności prognozy i budżetu samorządu, to jednak nie określa, która z tych instytucji ma charakter nadrzędny w kwestii tej zgodności.

Kolejną wadą prognozy finansowej jest brak prawnego określenia przedziału czasowego na jaki sporządzany powinien być taki dokument (tak jak ma to miejsce w przypadku planu finansowego państwa). Praktyka pokazuje, że jednostki

10 Ibidem, art. 226.

11 L. Hanus, Wieloletnia prognoza finansowa jednostek samorzadu terytorialnego, „Finanse Publiczne" 2010, nr 8, s. 24. 
samorządowe dysponują uchwaloną prognozą, obejmującą nawet 23-25 lat. Biorąc pod uwagę, iż ustawodawca zastrzegł realność tego dokumentu, tak długi czas wypacza ją i kierowanie się dłuższym okresem sprawia, że staje się ona w pewnej części fikcyjna. Od samego początku funkcjonowania prognozy, realizacja dyrektywy realności powoduje liczne trudności, ze względu na swój wieloaspektowy charakter. Przede wszystkim, problem leży w konstrukcji prognozy - jej szczegółowości i okresu planowania. Im dłuższy okres obowiązywania prognozy, tym dyrektywa realistyczności staje się bardziej abstrakcyjna i praktycznie niemożliwa do realizacji. Realność prognozy może być analizowana w świetle sposobu w jaki samorządy powinny ją przestrzegać - czy tylko w ujęciu formalnym, poprzez zachowanie wewnętrznej spójności wartości liczbowych, czy również w ujęciu materialnym, tj. przez pryzmat realności realizacji przyjmowanych danych finansowych w prognozie? Według E. Kuzyniaka, gminy starając się wykazać spełnieniem wymogów w zakresie limitacji zadłużenia (art. 243 ustawy o finansach publicznych), zamiast podejmować działania naprawcze, ulegają pokusie zbyt optymistycznego planowania dochodów i wydatków ${ }^{12}$. Warto w tym miejscu przypomnieć, że pierwsze wieloletnie plany finansowe na poziomie samorządu zaczęto sporządzać w Stanach Zjednoczonych ${ }^{13}$. Objęto nimi jednostki samorządowe znajdujące się $\mathrm{w}$ trudnej sytuacji finansowej, w ramach działań naprawczych ${ }^{14}$. $\mathrm{W}$ krajach skandynawskich, planowanie wieloletnie w samorządzie, $\mathrm{w}$ obszarze finansów wprowadzono we wszystkich jednostkach. Okres objęty tym planowaniem nie przekracza więcej niż 3-4 lata, z monitorowaniem poziomu deficytu. Z kolei w Belgii i w Portugalii, wieloletnie plany finansowe sporządzane są na czas trwania kadencji organu stanowiącego. Takie rozwiązanie jest racjonalne i uzasadnione, głównie z punktu widzenia realności tego dokumentu. Kolejny problem stwarza pominięcie przez ustawodawcę podziału kompetencji dla organu stanowiącego i wykonawczego w zakresie dokonywania zmian w WPF. Należy zdecydować się, czy organ stanowiący ma jedynie biernie uchwalać ten plan, czy może aktywnie, $\mathrm{z}$ własnej inicjatywy wprowadzać zmiany (czy to jedynie kompetencja organu wykonawczego) $)^{15}$ ?

Wprowadzenie do systemu finansów samorządowych dokumentu o charakterze strategicznym (wieloletnim) należy ocenić pozytywnie. Każdy podmiot gospodarowania (a samorząd jest takim podmiotem) powinien działać według strategii długofalowej. Wyznaczone cele $\mathrm{i}$ zadania $\mathrm{w}$ samorządzie mobilizują

12 E. Kuzyniak, Wirtualne dochody nie rozwiq̨żą problemów wskaźnika zadłużenia, „Wspólnota” 2013, nr 20.

13 M. Bitner, Krzysztof S. Cichocki, J. Sierak, Standardy zarządzania długiem na szczeblu lokalnym i regionalnym oraz ich wpływ na finansowanie infrastruktury, Instytut Badań Systemowych Polskiej Akademii Nauk, Warszawa 2013, s. 130-140.

14 M. Stęszewski, Wieloletnia prognoza finansowa jednostki samorządu terytorialnego, „Biuletyn Skarbowy Ministerstwa Finansów" 2008, nr 2, s. 5.

15 Wyroki sądów administracyjnych są w tej mierze rozbieżne; por. L. Mażewski, Zmiany w budżecie JST, „Gazeta Samorządu i Administracji” 2016, nr 4, s. 37-38. 
do działania, jak też narzucają określone ograniczenia i reżimy. Przez dość długi okres, planowanie wieloletnie nie obowiązywało w finansach lokalnych, choć niektóre jednostki fakultatywnie wdrażały tego typu instrument zarządzania finansowego. Chcąc zapewnić prognozie rolę wieloletniego instrumentu zarządzania finansowego $\mathrm{w}$ gospodarce samorządu, powinna ona stać się dokumentem o charakterze ogólnym i ramowym. Pozwoliłoby to wyeliminować częste zmiany WPF. Treść prognozy powinna zawierać kluczowe i ogólne dane finansowe, jak też przedsięwzięcia (inwestycje) wieloletnie. Kolejną przesłanką w modyfikacji tego instrumentu jest uczynienie z prognozy podstawy do konstruowania budżetów rocznych, tak jak ma to miejsce w przypadku WPFP. Pozwoli to, wraz ze zmniejszeniem szczegółowości prognozy na uzyskanie statusu ogólnych ram finansowych. Koniecznością, zdaniem autorki, jest również ograniczenie horyzontu czasowego planowania, objętego prognozą. Problematyka zarządzania długiem może znaleźć się $\mathrm{w}$ innym dokumencie samorządu (podobnie jak na poziomie centralnym).

Analogicznie jak WPFP, prognoza powinna obejmować cztery lata, ewentualnie pięć - jest to czas trwania kadencji władz samorządowych. Nie musi to oznaczać eliminacji dokumentu w postaci prognozy długu i spłaty zobowiązań długoterminowych, który ze swej istoty jest instytucją uzasadnioną. Jednak wadliwym rozwiązaniem jest obowiązek zrównania okresu WPF z okresem, na który zaciągnięto lub planuje się zaciągnąć dług, szczególnie gdy okres jego spłaty jest rozłożony na wiele lat $(10,15,20 \mathrm{i}$ więcej). Zmiana ta pozytywnie wpłynie na rzeczywistą realizację dyrektywy realistyczności prognozy i tym samym, wyeliminuje fasadowe planowanie wieloletnie, oparte niejednokrotnie na nierealnych założeniach ${ }^{16}$. Nadto, należałoby rozważyć jak powiązać część zadań komunalnych, które są realizowane przez spółki komunalne z WPF. Ze względu na fakt, że budżet jednostki samorządowej i prognoza, zaliczane są do narzędzi stabilizacji systemu finansów publicznych, powiązanie przede wszystkim zobowiązań długoterminowych spółek komunalnych z WPF, wydaje się być konieczne (wykazany jest łączny dług samorządu). Oczywiście powyższe propozycje mają charakter ogólny i wymagają uszczegółowienia, jak również mogą być dyskusyjne i uzupełnione innymi postulatami zmian w zakresie modyfikacji konstrukcji WPF

16 Z. Dolewka, Wieloletnia prognoza finansowa jako instrument zarządzania finansami samorządowymi, [w:] Aktualne problemy samorządu terytorialnego po 25 latach jego istnienia..., s. 313-316. 



\section{Rozdział XIV}

\section{Problem przejrzystości gospodarki finansowej}

Działanie organów i administracji samorządowej powinno być dostępne, jawne i transparentne. Zagadnienie dostępności do informacji publicznej regulują przepisy prawa, na czele z ustawa o dostępie do informacji publicznej. Zgodnie z regulacją, każdemu przysługuje prawo do informacji publicznej, obejmujące uprawnienia do:

- uzyskania informacji publicznej,

- wglądu do dokumentów urzędowych,

- dostępu do posiedzeń kolegialnych organów władzy publicznej pochodzących z powszechnych wyborów ${ }^{1}$.

Dostępność do informacji polega na łatwości i swobodzie w pozyskaniu istotnych danych o procesach funkcjonowania oraz rozwoju struktur samorządowych. Z kolei, jawność tych procesów oraz procesów decyzyjnych w zakresie zarządzania, posiada rangę kluczowej zasady działania władz publicznych. W gospodarce finansowej, zasada jawności została zawarta $\mathrm{w}$ ustawie o finansach publicznych i w tzw. ustawach ustrojowych. Przesłanką jawności działania jest jego przejrzystość, pojmowana jako zrozumiały i czytelny odbiór informacji przez każdego obywatela (mieszkańca). Odnosząc postulat transparentności do gospodarowania środkami publicznymi należy podkreślić, że przejrzystość stanowi swoisty klucz do poznania mechanizmów i ich konsekwencji w gospodarce finansowej dla przeprowadzenia ogólnej oceny kondycji ekonomicznej samorządu.

Praktyka dowodzi, że zapotrzebowanie społeczne na informacje dotyczące gospodarki finansowej państwa, czy jednostek samorządu, jest relatywnie duże. Zwraca się uwagę na pewną hermetyczność danych w tym zakresie, bowiem nie dla wszystkich są one zrozumiałe i zachęcają do lektury. Niemniej należy pamiętać, że obywatel ma prawo do informacji publicznej, w tym m.in. o stanie finansów i mieniu komunalnym, jakim dysponuje samorząd w Polsce. Jak zwraca

1 Art. 2 i 3 ustawy z dnia 6 września 2001 r. o dostępie do informacji publicznej (tekst jednolity: Dz. U. z 2019 r., poz. 1429 ze zm.). 
uwagę B. Filipiak, aktualny system przeprowadzenia oceny kondycji gospodarki finansowej nie sprawdza się, a obowiązujące regulacje prawne nie zapewniają kompleksowej informacji ${ }^{2}$.

Jawność i przejrzystość finansów publicznych została zapewniona w polskim prawie. Art. 61 ust 1 Konstytucji RP stanowi, że obywatel ma prawo do uzyskiwania informacji o działalności organów władzy publicznej oraz osób pełniących funkcje publiczne. Warto zaznaczyć, iż szczegółowy sposób realizacji tych zasad określa ustawa o finansach publicznych ${ }^{3}$. W świetle prawa, gospodarka środkami publicznymi jest jawna. Przez jawność należy rozumieć swobodny dostęp mieszkańca (podmiotu gospodarczego, organizacji) do informacji o działalności państwa, samorządu w wymiarze finansowym. Z kolei o przejrzystości finansów publicznych można mówić, gdy udostępnione dane w tym zakresie pozwalają uzyskać pełen, rzetelny i zrozumiały obraz stanu gospodarki finansowej państwa i jednostek samorządowych oraz innych podmiotów sektora publicznego ${ }^{4}$. Przy braku zachowania pełnej przejrzystości gospodarowania środkami publicznymi, realizacja zasady jawności jest w zasadzie bezprzedmiotowa. Zdaniem M. Jastrzębskiej, źródła ograniczające jawność i przejrzystość gospodarki finansowej tkwią w zjawiskach dysfunkcyjnych gospodarki samorządowej ${ }^{5}$.

Przegląd i ocena przejrzystości gospodarowania środkami publicznymi pozwala stwierdzić, że upublicznione informacje w tym obszarze są skierowane przede wszystkim do specjalistów zajmujących się problematyką finansów publicznych. Ponadto, nie zawierają one wszystkich niezbędnych danych dla celów np. badań porównawczych (benchmarkingowych) ${ }^{6}$. Z dostępnych statystyk wynika, że liczba zatrudnionych pracowników samorządowych w poszczególnych urzędach komunalnych nie jest nigdzie podawana. Nie wykazywane jest również całkowite zadłużenie danej jednostki samorządu, obejmujące długi spółek komunalnych ${ }^{7}$. Nie wszystkie samorządy w sposób przejrzysty i szczegółowy podają, na co dokładnie zostały wydatkowane środki pochodzące $\mathrm{z}$ zaciągniętego kredytu, pożyczki, czy ewentualnie wyemitowanych obligacji komunalnych. Trudności również przysparza odszukanie informacji na jakie wydatki budżetowe przeznaczono środki z rezerwy ogólnej.

2 B. Filipiak, Metodyka kompleksowej oceny gospodarki finansowej jednostki samorzadu terytorialnego, Wydawnictwo Difin, Warszawa 2009, s. 322.

3 Rozdział 4 ustawy z dnia 27 sierpnia 2009 r. o finansach publicznych...

4 W. Misiąg, A. Niedzielski, Jawność i przejrzystość finansów publicznych w Polsce w świetle standardów Międzynarodowego Funduszu Walutowego, Zeszyty Instytutu Badań nad Gospodarką Rynkową, Warszawa 2001, nr 29, s. 5.

5 M. Jastrzębska, Jawność i przejrzystość sprawozdawczości jednostek samorządu terytorialnego - ocena i rekomendacje, „Nierówności Społeczne a Wzrost Gospodarczy” 2018, nr 56, s. 64.

6 Zidentyfikowanie najlepszych praktyk.

7 Będących w $100 \%$ własnością jednostki samorządowej.

8 Według art. 222 ust. 1 ustawy z dnia 27 sierpnia 2009 r. o finansach..., może to być kwota stanowiąca od 0,1 do $1 \%$ wydatków budżetu. 
Trzeba zaznaczyć, że prawidłowe gospodarowanie środkami publicznymi jest bardzo ważne i istotne z punktu widzenia mieszkańca, obywatela, przedsiębiorcy, czy innych podmiotów. Właściwe ich wykorzystanie wpływa na wzrost i rozwój społeczno-gospodarczy samorządu (i państwa), tworzenie dodatkowych miejsc pracy, ochronę najuboższych grup społecznych, zapewnienie równego dostępu do podstawowych usług publicznych itd. Przy przejrzystym i jawnym systemie finansów publicznych wzrasta efektywność gospodarowania środkami publicznymi, gdyż marnotrawione pieniądze są bardziej widoczne.

Jak wspomniano, jednostki samorządu samodzielnie prowadzą gospodarkę finansową na podstawie uchwalonego budżetu. Odpowiedzialnym za realizację tego bardzo ważnego dokumentu ${ }^{9}$ jest organ wykonawczy. Informacje w nim zawarte powinny być objęte szczególną kontrolą społeczną. W budżetach jednostek samorządu dochody, jak i wydatki publiczne klasyfikuje się według działów i rozdziałów klasyfikacji budżetowej, określających rodzaj działalności oraz paragrafów wskazujących na rodzaj dochodu i przeznaczeniu wydatku. Należy wspomnieć, że polska klasyfikacja budżetowa dochodów i wydatków oraz przychodów i rozchodów jest bardzo szczegółowa, stąd też i obszerna.

Wydatkowanie środków publicznych z budżetów wpływa na jakość i zakres zaspokajania wielu potrzeb społecznych. Mieszkaniec (obywatel) jest odbiorcą szeroko rozumianych usług publicznych, które dostarcza gmina, powiat, województwo, państwo. W wyborach wyłania on przedstawicieli do poszczególnych organów władzy publicznej. Ci drudzy stanowią prawo w zakresie wysokości podatków, opłat lokalnych (w tym m.in. za niektóre usługi publiczne), a następnie uchwalają budżet i odpowiadają za jego realizację. Obywatel płaci podatki, wnosi opłaty, ale w pewnym sensie ma utrudniony dostęp do rzetelnych informacji dotyczących redystrybucji środków finansowych ${ }^{10}$. W rzeczywistości nie ma dobrej komunikacji pomiędzy organami władzy publicznej, a obywatelami w obszarze gospodarki finansami publicznymi. Może to wynikać m.in. z braku umiejętności (albo chęci) przygotowania czytelnych, kompleksowych oraz dostępnych powszechnie materiałów finansowych ${ }^{11}$. Trzeba pamiętać, że użytkownikami informacji finansowej są:

- przede wszystkim społeczność lokalna (mieszkańcy),

- organ stanowiący jednostki samorządowej,

- instytucje kontroli (w szczególności rio, NIK, Urząd Zamówień Publicznych itp.),

- kredytodawcy, pożyczkodawcy (np. banki, fundusze celowe),

9 O charakterze lokalnym bądź regionalnym.

10 Ważne są pytania, na jaki cel zostały przeznaczone i wydatkowane oraz jakie efekty osiągnięto.

11 Organy władzy wykonawczej bardzo rzadko udostępniają - m.in. na stronach internetowych (BIP) - dane o zatrudnieniu w urzędzie, jak i całościowym koszcie utrzymania administracji publicznej. Wydatki z tym związane są zapisane zazwyczaj w różnych podziałkach budżetowych. 
- organizacje pozarządowe,

- inni, w tym analitycy ekonomiczni i finansowi.

Ważnym źródłem regulacji w zakresie przejrzystości i jawności finansów publicznych jest opracowany i przyjęty w 1998 r. przez Międzynarodowy Fundusz Walutowy dokument o nazwie Kodeks przejrzystości polityki fiskalnej - deklaracja regu $1^{12}$. Zawiera on zbiór wytycznych należytej gospodarki środkami publicznymi. Informacja publiczna jest często nieczytelna i niepełna. Jeśli przejrzystość i czytelność danych finansowych są ograniczone, a zrozumienie tych informacji wymaga znajomości prawa finansowego i ekonomii, wtedy trudno mówić o jawności finansów publicznych ${ }^{13}$. Sprawozdania finansowe i budżetowe powinny pełnić różne funkcje, $w$ tym informacyjną, dokumentacyjną i analityczną. Tymczasem w rzeczywistości są to informacje skierowane tylko do określonej grupy specjalistów, a nie do obywateli.

Zdaniem A. Borodo, klasyfikacja budżetowa nie powinna być zbyt złożona, ponieważ staje się barierą dla przeciętnie wykształconego obywatela, $\mathrm{w}$ celu dokonania oceny wydatków budżetowych ${ }^{14}$. Informacje prezentowane $\mathrm{w}$ sprawozdaniach $\mathrm{z}$ wykonania budżetu oraz $\mathrm{w}$ raporcie o stanie gminy powinny być zrozumiałe, przydatne, wiarygodne, istotne i porównywalne. Zaangażowanie obywateli w proces partycypacji społecznej, w tym gospodarowania środkami publicznymi jest dalece niewystarczający. Stąd wciąż aktualna jest potrzeba poszukiwań nowych rozwiązań budowy społeczeństwa obywatelskiego oraz nowych metod komunikowania się władz publicznych z obywatelami. Informacje o działaniach władzy publicznej powinny być udostępniane powszechnie, przy użyciu wszystkich możliwych form prezentacji i elektronicznych komunikatorów (m.in. strony internetowe jednostek samorządowych, biuletyn informacji publicznej (BIP), broszury, foldery, tablice informacyjne itp.) oraz bezpośrednich spotkań. Dodatkowo do danych o sytuacji finansowej samorządu powinny być dołączone informacje o stanie zatrudnienia w administracji samorządowej i w służbach komunalnych, jak również te obrazujące kondycję finansową spółek komunalnych wraz z zasobem majątkowym. Społeczność lokalna nie ma dostępu do tego rodzaju danych, charakteryzujących kompleksowo gospodarkę finansową samorządu. Brak jest możliwości porównania kosztów z efektami, także w przekroju komparatywnym. W związku z tym trudno jest mówić o transparentności funkcjonowania władz i administracji samorządowej.

12 Code of Good Practices on Fiscal Transparency - Declaration of Principles (Dziennik Urzędowy Unii Europejskiej C 384, 10/12/1998).

13 Zob. M. Postuła, Zasadnicze działania w obszarze nowego zarządzania finansami publicznymi w Polsce, [w:] Finanse 2009 - Teoria i praktyka. Finanse publiczne I, Zeszyty Naukowe Uniwersytetu Szczecińskiego nr 546, Szczecin 2009, s. 314-315.

14 A. Borodo, Polskie prawo finansowe. Zarys ogólny, Wydawnictwo TNOiK, Toruń 2005, s. 164. 


\section{Rozdział XV}

\section{Podstawowe mierniki badania sytuacji finansowej jednostek samorządowych}

Samorząd terytorialny, po 30. latach funkcjonowania w Polsce, powoli traci autonomię finansową, co ogranicza samodzielność i niezależność decyzyjną. Według A. Szewczuka, rzeczywisty stan finansów samorządu powinien być mierzony na podstawie możliwości uzyskania dochodów i przychodów, wystarczających na pokrycie zadań własnych i zleconych ${ }^{1}$. Dochody własne wykazują tendencję malejącą, zaś subwencja ogólna i dotacje celowe z budżetu państwa nie wystarczają na pełną realizację wielu zadań własnych. Niedobór środków finansowych dotyczy także wykonywania zadań zleconych. Ostatnia sytuacja nie powinna mieć miejsca, ponieważ są to zadania administracji rządowej przekazane jednostkom samorządowym w przekonaniu, że zostaną wykonane efektywniej. Realizacja tych zadań powinna być uwarunkowana przekazaniem odpowiednich wielkości środków finansowych z budżetu państwa. Zmuszanie samorządów, regulacjami prawnymi (ustawami) do wykonywania zadań zleconych bez przekazania adekwatnych środków jest niesprawiedliwe i kłóci się wprost $\mathrm{z}$ ideą samorządności. Ocena wykonania zadań zleconych obarczona jest kontrolą administracji rządowej, z punktu widzenia wielu kryteriów (nie tylko legalności). Z pozycji racjonalności, samorządy znajdujące się w takiej sytuacji powinny zaprzestać wykonywania tych zadań w chwili wyczerpania środków finansowych przekazanych na ten cel $^{2}$. W grę wchodzi też rozwiązanie polegające na uruchomieniu procedur postępowania są-

1 A. Szewczuk, Strategie gospodarowania środkami publicznymi w jednostkach samorzadu terytorialnego na tle ujawniających się zjawisk kryzysowych, [w:] Finanse 2009 - Teoria i praktyka. Finanse publiczne II, Zeszyty Naukowe Uniwersytetu Szczecińskiego nr 547, Szczecin 2009, s. 233.

2 Należy zaznaczyć, że zadania zlecone realizowane są m.in. przez urzędy stanu cywilnego. Zamknięcie tych instytucji prowadzi do paraliżu świadczenia tego typu usług administracyjnych. Wobec tego niektóre samorządy gminne wprowadzają krótszy czas pracy tych placówek (np. od godz. 8 do 12). Skutkuje to niższymi kosztami wykonania tego rodzaju zadania zleconego, ale powoduje dużą niedogodność i uciążliwość dla obywateli, a tym samym zwiększa koszty społeczne. 
dowego dla wyegzekwowania kosztów poniesionych na realizację zadań zleconych. Wadą tego rozwiązania jest długi okres oczekiwania na rozstrzygnięcie.

Można wyróżnić trzy koncepcje oceny sytuacji finansowej jednostek samorządu. Pierwszą - jest propozycja Ministerstwa Finansów, która odnosi się do wszystkich samorządów i stanowi pełną bazę porównawczą. Kolejna metoda jest stosowana przez agencje ratingowe, m.in. Fitch Polska ${ }^{3}$. Ocena ratingowa ma charakter funkcjonalny. W analizie duży nacisk położony jest na ocenę płynności i zdolności jednostki samorządowej do regulowania zaciągniętych zobowiązań. Następną ze stosowanych metodyk jest analiza i ocena sprawozdań finansowych samorządu. Jest to metoda zaczerpnięta $\mathrm{z}$ analizy finansowej przedsiębiorstw. Najbardziej powszechnym zestawem wskaźników do oceny sytuacji finansowej samorządu jest katalog opracowany przez Ministerstwo Finansów. Wskaźniki podzielone zostały na trzy grupy: budżetowe, „na mieszkańca” (per capita) oraz zobowiązań według tytułów dłużnych. Równie popularnym opracowaniem jest zestaw proponowany przez agencję Fitch Polska, stosowany jako podstawa nadawania ocen ratingowych. Wykorzystywane w tym zakresie wskaźniki dzielą się na pięć grup: wskaźniki budżetowe, wskaźniki dochodów, wskaźniki wydatków, wskaźniki zadłużenia, wskaźniki finansowania wydatków majątkowych. Oceniając kondycję finansową samorządu wykorzystuje się zwykle cztery grupy wskaźników:

- płynności finansowej (mierząc zdolność do wywiązywania się z krótkoterminowych zobowiązań),

- zadłużenia (analizując wielkość zadłużenia i zdolność do obsługi tego zadłużenia),

- atrakcyjności jednostki samorządu terytorialnego,

- samodzielności finansowej jednostek samorządowych.

Zastosowanie określonego zestawu wskaźników znajduje swój wyraz również w wymiarze praktycznym, bowiem oceny konstruowane są przez różne instytucje (np. banki, instytucje finansowe, instytucje konsultingowe). Jak twierdzi J. Sierak, analiza wskaźnikowa jest ważnym narzędziem oceny gospodarki budżetowej, płynności finansowej oraz wiarygodności kredytowej samorządu ${ }^{4}$.

Pierwszym przybliżeniem w ocenie kondycji finansowej samorządu jest obserwacja udziału dochodów własnych w dochodach budżetu ogółem. Relacja ta informuje o zakresie samodzielności dochodowej badanego samorządu. Analiza samodzielności dochodowej dokonywana jest w dwóch płaszczyznach:

- ogólnej, z punktu widzenia udziału dochodów własnych,

- władztwa podatkowego, czyli możliwości kształtowania wielkości dochodów podatkowych.

Dochody własne samorządu pochodzą z wielu źródeł ich powstawania. Można wyodrębnić sześć grup dochodów własnych:

3 Agencja ta jest najczęściej wybierana przez jednostki samorządowe, które zlecają taką ocenę.

4 J. Sierak, Analiza wskaźnikowa a model zarzq̨dzania jednostka samorzqdu terytorialnego, [w:] Gospodarka lokalna i regionalna w teorii i praktyce, Prace Naukowe Akademii Ekonomicznej we Wrocławiu nr 1083, Wrocław 2005, s. 631. 
- udziały w podatkach dochodowych od osób fizycznych (PIT) i osób prawnych (CIT),

- podatki lokalne,

- opłaty lokalne,

- dochody realizowane przez jednostki organizacyjne samorządu,

- dochody majątkowe,

- pozostałe (w tym: kary, grzywny, odsetki na rachunku bankowym, dywidendy od spółek).

Z wymienionych źródeł dominującą grupę stanowią udziały w podatku dochodowym PIT i CIT. Należy podkreślić, że samorządy w Polsce nie mają wpływu na wielkość uzyskiwanych z tego tytułu dochodów. Wszelkie korekty tych dochodów w postaci ulg, zwolnień, waloryzacji obowiązujących progów podatkowych, waloryzacji ustawowych zryczałtowanych kosztów uzyskania przychodów i kwoty zmniejszającej podatek, podejmowane są przez ustawodawcę. Ostateczna wielkość środków $\mathrm{z}$ tego źródła w budżecie samorządu jest silnie uzależniona od koniunktury, aktywności gospodarczej (PKB, ceny) w kraju i na świecie oraz prowadzonej krajowej polityki zatrudnienia (wynagrodzenia).

Ważnym źródłem dochodów własnych samorządu w Polsce są podatki i opłaty lokalne. Wielkości te w przekroju porównywanym, mogą być użyteczne dla oszacowania wydatków z tym związanych, dla budżetów gospodarstw domowych. Wysokość podatków i opłat lokalnych stanowi kryterium oceny kosztów życia w danej wspólnocie samorządowej, a tym samym jej atrakcyjności i konkurencyjności. W każdym samorządzie, zwłaszcza w gminnym, istnieje dylemat: czy podnosić poziom i jakość świadczonych usług komunalnych, kosztem wzrostu podatków i opłat lokalnych? Przyjmując założenie, że nie występują rezerwy zdolności produkcyjno-usługowych, jedynym rozwiązaniem jest podniesienie poziomu tych źródeł dochodów, na które władze samorządu mają wpływ. Jest to posunięcie bardzo ryzykowne i niepopularne ze społecznego punktu widzenia, ponieważ przynosi dodatkowe obciążenie budżetu gospodarstw domowych. Na takie działanie decydują się zwykle władze samorządu w połowie kadencji. Podwyżki podatków i opłat można uzasadnić oraz przekonać społeczność lokalną do jej słuszności, jedynie w przypadku modernizacji usług komunalnych. W przeciwnym razie, ocena jest negatywna, gdyż mieszkańcy ponoszą koszt bez oczekiwanego i obiecywanego efektu rzeczowego. Taka sytuacja jest możliwa w warunkach budżetowania tradycyjnego. Alternatywnym rozwiązaniem może być opracowanie budżetu w omówionej formule budżetu zadaniowego, który zawiera miary efektów z poniesionych wydatków.

Wynik operacyjny daje możliwość oceny potencjalnej zdolności i możliwości jednostki samorządowej do spłaty zobowiązań, a także do finansowania wydatków o charakterze inwestycyjnym ${ }^{5}$. Celem kierowania środków na przedsięwzięcia in-

5 E. Chojna-Duch, Zagadnienie długu jednostek samorzadu terytorialnego - nowe propozycje prawne, „Samorząd Terytorialny” 2008, nr 11, s. 7. 
westycyjne $^{6}$ jest wyposażenie jednostkę samorządową $\mathrm{w}$ dobra publiczne, które mają zaspokajać zbiorowe potrzeby mieszkańców. W ten sposób, tworząc dobrą infrastrukturę komunalną chcą również przyciągnąć inwestorów, dzięki którym mogą zwiększyć w przyszłości swoje dochody w budżecie. Niewątpliwie wydatki przeznaczane na inwestycje przyczyniają się do zwiększenia wartości mienia komunalnego, jednakże nie każda inwestycja realizowana przez władze samorządowe ma wpływ na lepszą jakość życia mieszkańców

Panuje pogląd, że miasto (gmina) w którym nie inwestuje się - „zamiera”. Niewątpliwie przeznaczanie w budżecie jednostki samorządowej niewielkich środków na wydatki majątkowe, prowadzi do wielu negatywnych zjawisk społecznych i gospodarczych. O rozwoju każdej jednostki (podmiotu) świadczy właśnie skłonność do inwestowania. Przeznaczanie środków finansowych na przedsięwzięcia inwestycyjne czy modernizacyjne (odtworzeniowe), to dążenie do powiększenia wartości mienia komunalnego, ale przede wszystkim powinno wpływać na wzrost poziomu jakości życia, przez lepsze zaspokajanie zbiorowych potrzeb. Jak pisze E. Wojciechowski, realizacja zadań użyteczności publicznej z reguły polega na wykorzystaniu majątku komunalnego (urządzeń i instytucji), tworzącego podstawę dla funkcjonowania gospodarki i warunków życia ludności ${ }^{8}$. Potrzeby inwestowania w infrastrukturę techniczną i społeczną w każdym samorządzie są relatywnie duże. Ich charakterystyczną cechą jest wysoka kapitałochłonność. Przy mocno ograniczonych zasobach finansowych, władze samorządowe podejmując się tych wyzwań, biorą na siebie duży wysiłek i trud, związany niejednokrotnie z wieloma wyrzeczeniami. Dla realizowania inwestycji trzeba zgromadzić odpowiednie środki pieniężne. Trudno jednak przyjąć zasadę maksymalizowania nakładów inwestycyjnych za wszelką cenę 9 .

Wysokość środków przeznaczonych w budżetach samorządu na wydatki majątkowe jest silnie uzależniona od poziomu dochodów ogółem. Należy zaznaczyć, że skłonność do inwestowania w samorządzie można określić za pomocą wielu wskaźników ekonomicznych, o różnym znaczeniu informacyjno-analitycznym. Skłonność do inwestowania jest kategorią wielowymiarową, łączącą elementy społeczne z ekonomicznymi. Wskaźniki oceny mogą mieć charakter obiektywny (mierzalny) - poprzez wyrażenie np. w jednostkach wartościowych, bądź subiektywny. W literaturze przedmiotu, najczęściej spotykamy się z miernikami obiektywnymi, pozyskanymi z publicznych źródeł statystycznych, pochodzących ze sprawozdawczości budżetowej. W wielu przeprowadzonych badaniach,

6 Budowa i rozbudowa obiektów komunalnych oraz zakup gotowych środków trwałych.

7 Przykładem może być budowa fontann, różnych hal (np. wystawowych), pomników itp., a brakuje środków na budowę i naprawę dróg, modernizację oświetlenia ulicznego, remonty szkół, zasobów mieszkaniowych itd.

8 E. Wojciechowski, Samorząd terytorialny w warunkach gospodarki rynkowej, Wydawnictwo Naukowe PWN, Warszawa 1997, s. 20.

9 W. Misiąg, Rola inwestycji w budżecie państwa i w budżetach gmin, Instytut Badań nad Gospodarką Rynkową, Warszawa 1997, s. 2. 
ich autorzy przyjęli, że podstawową wielkością obrazującą poziom skłonności do inwestowania jest wielkość dochodów własnych oraz ich udział w dochodach ogółem. Dochody własne odzwierciedlają nie tylko stopień samodzielności finansowej samorządu, ale także potencjał gospodarczy, lokalne źródła zamożności oraz stopień skłonności do inwestowania.

Niewątpliwie o poziomie inwestowania mogą świadczyć również inne wskaźniki, m.in. takie jak: wydatki majątkowe per capita, relacja wydatków majątkowych do dochodów ogółem, relacja wydatków majątkowych do dochodów własnych, relacja wydatków majątkowych do wydatków ogółem, tempo zmian wydatków majątkowych, nadwyżka operacyjna. Planując określone przedsięwzięcia inwestycyjne zawsze należy zadać pytania:

- czy wykonanie tego zadania jest niezbędne?

- czy należy realizować je teraz?

- czy istnieje możliwość osiągnięcia tego samego rezultatu, ale przy niższych nakładach finansowych?

Nie należy również rozpoczynać zbyt wiele inwestycji angażujących duże środki finansowe, gdyż po pewnym czasie może okazać się, że samorząd nie jest w stanie ich sfinansować i będą znacznie rozciągnięte w czasie. Takie działanie prowadzi do generowania dodatkowych kosztów. Inwestowanie jest angażowaniem środków w przedsięwzięcia, dzięki którym w przyszłości można uzyskać korzyści. Dlatego m.in. każda decyzja o podjęciu inwestycji powinna być poprzedzona analizą jej celowości oraz analizą techniczno-ekonomiczną, umożliwiającą następnie ocenę jej efektywności.

Ważnym obszarem oceny sytuacji finansowej samorządu jest płynność finansowa, czyli zdolność do spłaty zobowiązań. Łączy się z tym ocena potencjału inwestycyjnego i wiarygodności kredytowej. Na globalną ocenę kondycji finansowej samorządu składają się:

- wskaźniki dynamiki i struktury dochodów oraz wydatków ogółem, jednostkowo (na mieszkańca),

- wskaźniki oceny zdolności kredytowej (udział zadłużenia w dochodach, koszt obsługi zadłużenia),

- wskaźniki ogólnej sytuacji finansowej (udział dochodów własnych, wolne środki w budżecie).

Miarą jakości wydatków publicznych jest stopień, w jakim przyczyniają się one do efektywnej realizacji celów strategicznych i priorytetów rozwojowych, $\mathrm{w}$ tym dotyczących wsparcia wzrostu gospodarczego i niwelowania nierówności społecznych. Nadwyżka operacyjna powinna być jednak wstępnym kryterium badania zdolności kredytowej jednostki samorządowej, a także parametrem, który należy uwzględnić w formule ograniczającej zadłużenie samorządu. Wskaźnik obciążenia dochodów bieżącym długiem pozwala na ocenę wielkości zadłużenia w odniesieniu do dochodów bieżących. Wskaźnik obciążenia dochodów bieżących obsługą zadłużenia, obrazuje zaangażowanie dochodów bieżących w koszt obsługi zadłużenia i spłaty rat kapitałowych (w tym również wykup samorządowych 
papierów wartościowych). Warto dodać, że im większa jest wartość tej relacji, tym wyższe ryzyko wystąpienia niewypłacalności jednostki samorządowej. W ocenach zdolności samorządu do spłaty zobowiązań brany jest również pod uwagę m.in. wskaźnik obciążenia dochodów bieżących wydatkami bieżącymi i obsługą zadłużenia. Wartość tego wskaźnika większa od 100\%, świadczy o tym, że dochody bieżące nie wystarczają na pokrycie wydatków bieżących i obsługi zadłużenia. Ocena stanu finansów lokalnych uwzględniająca wszystkie wymienione wskaźniki, jest podstawą do zapewnienia bezpieczeństwa finansowego, pojmowanego jako zdolność do realizacji zadań publicznych oraz utrzymania wiarygodności finansowej, związanej ze spłatą już zaciągniętych zobowiązań (krótko, średnio i długoterminowych), jak też przyszłych.

Ułomnością ocen sytuacji finansowej samorządu jest brak uwzględnienia w tych opracowaniach (raportach) wszystkich syntetycznych danych finansowych, obejmujących każdą jednostkę organizacyjną samorządu. Chodzi również o podmioty, które posiadają osobowość prawną i samodzielnie gospodarują, niemniej są własnością samorządu. Nieuwzględnienie tych danych, np. w zakresie zaciągniętego długu, powoduje, iż oceny kondycji finansowej tych jednostek samorządowych są niekompletne i otrzymujemy niepełny obraz kondycji finansowej. Organ wykonawczy w żadnym sprawozdaniu, jak też raporcie (np. o stanie gminy) nie podaje informacji o sytuacji finansowej spółek komunalnych.

Komunalne podmioty z osobowością prawną nie podają do publicznej wiadomości sprawozdań finansowych ${ }^{10}$, przedstawiających ich sytuację finansową i ekonomiczne wyniki działalności, jak też sprawozdania biegłego rewidenta $z$ badania rocznego sprawozdania finansowego. Działalność większości tych podmiotów jest „okryta” tajemnicą, co kłóci się z jawnością i przejrzystością działania władz samorządu. Mieszkańcy jako „właściciele” komunalnych podmiotów gospodarczych ${ }^{11}$ (działających w warunkach monopolu naturalnego) i jednocześnie odbiorcy usług świadczonych przez te podmioty (płacą określoną opłatę), nie mają dostępu do danych o sytuacji finansowej podmiotu komunalnego oraz o jego zasobach gospodarczych. Nie służy to celom porównawczym, jak też określeniu realnych możliwości finansowych głównie dużych samorządów, które charakteryzują się niższą transparentnością w porównaniu do małych samorządów. Wszystko to sprawia, że trudno jest badać ekonomiczną efektywność usług publicznych oraz efektywność przedsiębiorstw komunalnych.

10 Dotychczasowa praktyka wskazuje, że sporadycznie tylko niektóre z nich zamieszczali to sprawozdanie na swojej stronie internetowej. Sprawozdania finansowe spółek komunalnych można było znaleźć na stronach internetowych w Białymstoku, w Krakowie, jak też w Poznaniu. Cząstkowe informacje w zakresie strat bądź zysków osiąganych przez te podmioty, przedstawiały lokalne media.

11 Szczególnie kiedy jednostka samorządowa ma 100\% udziałów w spółce (jednoosobowa spółka). 


\section{Rozdział XVI}

\section{Użyteczność polityczna i społeczna raportu o stanie jednostki samorządowej}

Podstawowymi dokumentami (narzędziami analizy i oceny) opisującymi gospodarkę finansową samorządu są:

- dokumenty planistyczne (budżet, wieloletnia prognoza finansowa),

- dokumenty finansowe (sprawozdania budżetowe, półroczne i roczne sprawozdanie z wykonania budżetu),

- dokumenty ekonomiczne (sprawozdanie finansowe - bilans wraz z załącznikami, informacja o stanie mienia).

Od 2018 r. ustawodawca wprowadził nowy instrument polityki samorządowej w postaci raportu o stanie samorzadu ${ }^{1}$. W 2019 r. wójtowie, burmistrzowie i prezydenci miast po raz pierwszy musieli przedstawić radnym i mieszkańcom raport o stanie gminy za $2018 \mathrm{r}$. Raport o stanie gminy stanowi w gruncie rzeczy sprawozdanie organu wykonawczego, dotyczące wdrażania lokalnych programów i uchwał w danym roku. Dokument obejmuje podsumowanie całokształtu działalności organu wykonawczego w roku poprzednim, a w szczególności realizację polityk publicznych, programów i strategii, uchwał rady gminy i budżetu obywatelskiego ${ }^{2}$.

Raport ten ma być $\mathrm{w}$ założeniu podstawą oceny działalności organu wykonawczego jednostki samorządowej $\mathrm{w}$ roku poprzednim, przez organ stanowiący. Procedura przyjęcia raportu o stanie jednostki samorządowej łączy się z procedurą absolutoryjną. Dokument musi być złożony do 31 maja każdego roku, tak by podczas sesji, na której radni oceniają sprawozdanie $\mathrm{z}$ wykonania budżetu i udzielają (bądź nie udzielają) absolutorium wójtowi, burmistrzowi, prezydentowi miasta - odbyła się również debata wokół raportu. Radni dyskutują nad raportem o stanie jednostki samorządu w pierwszej kolejności. W debacie nad raportem

1 Ustawa z dnia 11 stycznia 2018 r. o zmianie niektórych ustaw w celu zwiększenia udziału obywateli w procesie wybierania, funkcjonowania i kontrolowania niektórych organów publicznych (Dz. U. z 2018 r., poz. 130).

2 Art. 28aa ust. 2 ustawy z dnia 8 marca 1990 r. o samorządzie gminnym... 
głos mogą zabierać mieszkańcy wspólnoty, zgłoszeni i wybrani w odrębnej procedurze. Istotą debaty jest udział w niej osób zainteresowanych kwestiami poruszonymi w raporcie o stanie samorządu. Debata nad raportem może składać się nawet z kilku posiedzeń, ponieważ radni mogą uczestniczyć w niej bez żadnych ograniczeń czasowych. Coroczny raport o stanie gminy miał zwiększyć udział obywateli w procesie wybierania, funkcjonowania i kontrolowania organów gminy. Jednak jak wynika z badań Sieci WatchDog Polska, w 84\% gmin do debaty nie zgłosił się żaden mieszkaniec. Aby zapobiec podobnym sytuacjom, WatchDog Polska ogłosił projekt szkoleń dla samorządów ${ }^{3}$.

Ocena raportu stanowi podstawę wyrażenia ( $\mathrm{w}$ formie uchwały) wotum zaufania do dokonań organu wykonawczego w poprzednim roku kalendarzowym i musi być dokonana do 30 czerwca (tak jak uchwała w sprawie absolutorium, zgodnie z przepisami ustawy o finansach publicznych). Niepodjęcie uchwały o udzielenie wotum zaufania jest równoznaczne z podjęciem uchwały o nieudzieleniu organowi wykonawczemu wotum zaufania. Jeśli rada nie udzieli takiego wotum w dwóch kolejnych latach, otwiera to możliwość uruchomienia procedury o odwołanie organu wykonawczego w trybie przeprowadzenia referendum ${ }^{4}$.

Kluczową sprawą, która nie została rozstrzygnięta formalnie jest zakres i struktura raportu. Ustawodawca dość ogólnikowo potraktował formułę tego dokumentu. Nie przewidział dla ministra właściwego ds. administracji publicznej oraz wojewodów, kompetencji w zakresie procedury opracowania i weryfikacji raportu o stanie gminy. Wprawdzie radni gminy mogą określić (w drodze uchwały) szczegółowe wymogi dotyczące raportu, ale jak wynika z dotychczasowego doświadczenia, nie robią tego, pozostawiając tym samym swobodę organom wykonawczym. W efekcie wójtowie, burmistrzowie i prezydenci miast zawierają $\mathrm{w}$ raporcie te informacje, które sami uznają za słuszne. $Z$ przeglądu raportów dużych miast w Polsce, wynika, że mają one formułę autorską. Poza wymogami określonymi ogólnie w przepisach prawa, zawierają dane i informacje bardzo ogólne, na temat rozwoju i zdarzeń w danym mieście, przy czym nie zawsze jest to wynik i efekt działań władz oraz administracji samorządowej (np. Łódź). Część prezydentów zawarła w raporcie szczegółowe dane o rozwoju poszczególnych dziedzin miasta (np. Kraków, Wrocław).

Niektóre samorządy powielają wprost informacje zawarte najczęściej w rocznych sprawozdaniach $\mathrm{z}$ wykonania budżetu bądź w sprawozdaniu finansowym. Budzi to zastrzeżenia, bowiem raport jest objęty nadzorem wojewody, zaś sprawozdania $\mathrm{z}$ wykonania budżetu są przedmiotem zainteresowania regionalnych izb obrachunkowych (z racji pełnionego nadzoru nad gospodarką finansową). Wydaje się, że sprawy polityki finansowej lub budżetowej powinny być wyjęte $\mathrm{z}$ raportu,

3 Chęć wzięcia udziału zgłosiło prawie 40 gmin, jednak ostatecznie wybrano 12 jednostek. Są to: Bydgoszcz, Cieszyn, Czernichów, Izabelin, Lubartów, Miłomłyn, Ostróda, Sitkówka-Nowiny, Świdwin, Ustka, Wołomin, Zgierz oraz jako partnerskie Itawa, Pawonków, Piastów i Sędziejowice.

4 Art. 28aa ust. 10 ustawy o samorzq̨dzie gminnym... 
ponieważ są podstawą weryfikowania działalności organu wykonawczego w procedurze absolutoryjnej. Szkoda, że ustawodawca nie wykorzystał szansy uregulowania tego problemu przez pewne ujednolicenie struktury raportu. Daleko idąca swoboda w określeniu podstawowych informacji powoduje płynność i różnorodność podstaw przeprowadzenia oceny przez organ stanowiący. Oznacza to także niemożność zapoznania się z jego istotnymi elementami (które nie są publikowane w innych dokumentach) przez samych mieszkańców. Zaskakuje to, gdyż intencją ustawodawcy było wykorzystanie raportu, jako narzędzia w procesie partycypacji obywatelskiej w zarządzaniu sprawami publicznymi. Związek Miast Polskich opracował wzór raportu o stanie gminy, którym posiłkować mogą się jego miasta członkowskie ${ }^{5}$. Niestety już na wstępie, zamieszczono krytyczny komentarz, dotyczący art. 28aa ust. 1 ustawy o samorzadzie gminnym, który nakazuje organowi wykonawczemu w gminie przedstawienie radnym raportu corocznie do końca maja. Komentarz ten poddaje pod wątpliwość sens opracowania takiego dokumentu i analizowania go przez radnych z uczestnictwem mieszkańców.

W związku z tym, nadal brakuje dokumentu, który w formie zwartej i przejrzystej informowałby o istotnych decyzjach organu wykonawczego, rodzących doniosłe skutki ekonomiczne i finansowe. Powstaje w tym miejscu zasadne pytanie, czy raport o stanie jednostki ma przedstawiać w formie syntetycznej podstawowe informacje liczbowe i opisowe, czy też zawierać wyniki z przeprowadzonej analizy procesów i zjawisk zachodzących w samorządzie? Łączy się z tym kolejna kwestia, czy główną osią raportu mają być dokumenty obligatoryjne dotyczące dziedzin działalności gospodarki samorządu, czy też działalności nienależących do jego kompetencji (sektor prywatny, społeczny)? Bez wątpienia, w skład raportu muszą wchodzić istotne wielkości scharakteryzowane liczbowo i jakościowo oraz informacje związane z kontekstem (warunkami, otoczeniem) funkcjonowania samorządu. Przykładowymi informacjami o stanie gospodarki samorządu powinny być:

- wielkości charakteryzujące organizację samorządu,

- sposób zagospodarowania i procesy demograficzne,

- informacje o gospodarce samorządu (bezrobocie, pracujący, przedsiębiorczość),

- charakterystyka liczbowa infrastruktury technicznej i społecznej,

- priorytety rozwojowe i ich realizacja (polityki publiczne, programy, strategie),

- wielkość i struktura majątku,

- wielkość i struktura służb komunalnych,

- ocena kondycji finansowej samorządu.

Reasumując, raport o stanie samorządu powinien być zwartym opracowaniem zawierającym tylko syntetyczne wielkości liczbowe wraz z lapidarnym ich opisem i komentarzem. Tylko $\mathrm{w}$ ten sposób zapewniona będzie transparentność działania organu wykonawczego i jego efektów w kontekście efektywnego

5 Związek zrzesza ok. 300 miast w kraju. 
wykorzystania posiadanych zasobów gospodarczych. Tak zarysowany zakres przedmiotowy raportu pozwala wzbogacić podstawę formułowania oceny w procesie kontroli organów wykonawczych w gminie. Trzeba pamiętać, że nadmiar informacji (szczegółów) niczemu dobremu nie służy i przynosi odwrotny skutek. Utrudnia bowiem całościowe spojrzenie na sytuację samorządu i rozdrabnia uwagę, prowadząc do utraty przejrzystości stanu i działań. Ujednolicenie głównych elementów raportu posiada dodatkowy walor, polegający na możliwości stosowania badań i studiów porównawczych między różnymi jednostkami samorządu' ${ }^{6}$.

$\mathrm{W}$ raporcie, organ wykonawczy w gminie przedstawiając sukcesy, nie powinien zapomnieć o problemach społecznych i gospodarczych wspólnoty. Raport nie musi być swoistą „laurką" dla wójta, burmistrza, prezydenta miasta, ale powinien także informować rzetelnie o zagrożeniach, porażkach czy o słabych stronach gminy. Powinien zawierać informacje nad czym należy nadal pracować $\mathrm{w}$ perspektywie kolejnych wyzwań lokalnych. Równie ważna jest forma raportu, która zainteresuje mieszkańców. Warto też zadbać o odpowiednie rozłożenie akcentów w treści raportu. Nie chodzi tylko o wskazanie konkretnych działań i efektów w każdej sferze zadań samorządu. Potrzebne jest również bardziej pogłębione przedstawienie kilku najważniejszych osiągnięć i wyzwań, które zajmowały najwięcej uwagi w minionym roku. Warto pochwalić się największymi sukcesami, a jednocześnie zarysować cele na kolejny rok. Konstrukcja raportu powinna być bardzo prosta dla zapewnienia wysokiej przejrzystości i czytelności. W celu zainteresowania mieszkańców raportem, powinien on być opublikowany na stronach internetowych gminy. Można stwierdzić, że raport w takim kształcie stanowi istotny instrument zewnętrznej presji efektywnościowej na organie wykonawczym. Należy jednocześnie zauważyć, że z punktu widzenia użyteczności praktycznej i efektywności społecznej, tak zbudowany raport można uznać za cenniejszy dla mieszkańca, niż roczne sprawozdanie $\mathrm{z}$ wykonania budżetu, które z uwagi na uwarunkowania (wymogi) prawne jest bardziej adresowane do specjalistów z dziedziny finansów. Lektura sprawozdania budżetowego w średnim i dużym samorządzie jest trudna i czasochłonna, bowiem przeciętnie obejmuje nawet kilkaset stron?.

6 Przykładem może być dokument o charakterze rozwojowym. Jest nim program rozwoju, plan rozwoju oraz strategia rozwoju. Niezależnie od formy obejmują one specyfikację celów i zadań oraz dobór środków i metod ich osiągania oraz realizacji. W przypadku gospodarki przestrzennej, studium uwarunkowań i kierunków jest dokumentem obligatoryjnym i dla mieszkańca oraz radnego ważne znaczenie ma odsetek obszaru samorządu, objętego planami przestrzennego zagospodarowania w czasie wraz z wyjaśnieniem przyczyn zachodzących zmian.

7 Dla przykładu, sprawozdanie z wykonania budżetu Łodzi zawiera 513 stron formatu A4. 


\section{Rozdział XVII}

\section{Kierunki zmian systemowych i usprawniających}

\section{Zmiany systemowe}

Jedną z podstawowych zasad, którą powinni kierować się rządzący, zarówno organ wykonawczy (odpowiedzialny za przygotowanie projektu budżetu), jak i stanowiący (uchwalający budżet samorządu), jest imperatyw, aby nie wydać więcej niż stać na to samorząd. Dążenie do zrównoważenia dochodów i wydatków budżetu jest o tyle istotne, aby nie zadłużać nadmiernie przyszłych pokoleń. W rzeczywistości taka filozofia jest obca władzom samorządowym. Warto jednak podkreślić, że istnienie samorządu ma sens, gdy posiada on samodzielność decyzyjną, w tym finansową. Prawie każda decyzja podjęta w samorządzie rodzi skutki finansowe. Spadek udziału dochodów własnych w budżetach powoduje, iż autonomia finansowa tych jednostek maleje ${ }^{1}$. Dobrą sytuację finansową mają tylko te gminy, które na swoim terenie zawierają cenne zasoby naturalne, np. kopalnie, elektrownie (np. Kleszczów - najbogatsza gmina w Polsce), pełnią rolę „sypialni” dużych miast, są atrakcyjne turystycznie, mają status gminy uzdrowiskowej lub są położone blisko granic państwowych. Wtedy udział dochodów własnych w budżecie może być relatywnie wysoki (powyżej 60\%). Niestety takich samorządów w Polsce jest niewiele, a trzeba pamiętać, że to właśnie wysokość dochodów własnych w dużym stopniu decyduje o zdolności samorządu do realizacji zadań własnych.

Jak wiadomo, oprócz dochodów własnych w budżetach samorządu występują dochody uzupełniające w postaci subwencji ogólnej i dotacji celowych. Stanowią one formę transferów środków finansowych $\mathrm{z}$ budżetu państwa do budżetów samorządów. Zdaniem L. Patrzałka, ich cechą charakterystyczną jest to, że nie są

1 W latach 2008-2009 dochody własne stanowity w budżetach jednostek samorządowych ponad 50\%, od 2015 r. zmalały poniżej 50\% (z wyjątkiem województw i miast na prawach powiatu, przy czym w tych ostatnich wystąpiła tendencja malejąca). 
trwale oraz bezpośrednio powiązane $\mathrm{z}$ budżetem np. gminy, jak ma to miejsce w grupie dochodów własnych ${ }^{2}$. Transfery pieniężne są bardzo ważne dla samorządów słabszych ekonomicznie. Jeżeli zdecydowana większość jednostek samorządowych jest zaliczana do grupy słabszych ekonomicznie (powiaty i gminy wiejskie np. do 5 tys. mieszkańców), to ich byt (dalsze funkcjonowanie) stoi pod znakiem zapytania. Trzeba stworzyć taki system finansowania samorządu oraz taką liczbę jednostek, aby w miarę możliwości nie traciły autonomii finansowej i niezależności. Przeważający udział transferów w budżetach samorządu uzależnia go od państwa. Ponadto, dochody uzupełniające są przyznawane na podstawie różnych kryteriów, uznaniowych (decyzja subiektywna) i obiektywnych (mierzalnych wskaźników, kluczowych dla podjęcia decyzji).

Ewentualne możliwości zwiększania dochodów samorządowych praktycznie wyczerpały się. Teraz potrzebne są określone zmiany w prawie, ponieważ stawki podatku PIT i CIT są ustalane na szczeblu centralnym (dotyczy to też zwolnień, ulg itp.). Zmiany, jakie dokonywały się w systemie podatkowym w ostatnich 15 latach były niekorzystne dla budżetu samorządów, a straty nie zostały dotąd wyrównane. Generalnie podatki i opłaty lokalne nie przynoszą na tyle dużych wpływów, by wyrównać niedobór $\mathrm{w}$ budżecie przeciętnej gminy. Na dodatek samorządy nie mogą ustalać ich w dowolnej wysokości, lecz w ściśle określonych przepisami prawa przedziałkach. Stawki, w większości gmin miejskich i miast na prawach powiatu, zbliżyły się bądź osiągnęły już maksymalny poziom i w ten sposób wyczerpały możliwości zwiększenia tego źródła dochodów. W praktyce, to dochody własne decydują o tym, jaką zdolność ma samorząd do realizacji swoich zadań. Dotyczy to zwłaszcza gmin, których kondycja finansowa ma największy wpływ na codzienne życie mieszkańców. Niewystarczające dochody własne i ograniczenia w zaciągnięciu długu sprawiają, że niektóre samorządy coraz częściej nie mogą decydować o swoich wydatkach, a stają się jedynie administratorami funduszy przekazywanych z budżetu centralnego.

Dochody samorządów należy dostosować do zadań i celów (zasada adekwatności). Jeśli ustawodawca nie zdecyduje się na wzmocnienie finansów lokalnych przez np. zwiększenie udziału wpływów z PIT oraz przejęcie zadań oświatowych przez administrację rządową (bądź zmianę algorytmu) to system finansów publicznych powinien ulec przebudowie. Warto zastanowić się nad prawdziwym urzeczywistnieniem decentralizacji finansów i przywróceniem zasad obowiązujących w okresie międzywojennym. Samodzielność finansowa ówczesnych miast wynikała z naturalnego związku pomiędzy funkcjami miastotwórczymi (rozwojowymi) a funkcjami obsługi (wydatki). Dochody przeznaczane były na realizację zadań związanych z urządzeniami infrastrukturalnymi, przy relatywnie mniejszym udziale transferów (dotacje, subwencje z budżetu państwa). Miasta obok działalności użyteczności publicznej (niezarobkowej), prowadziły też działalność

2 L. Patrzałek, Finanse samorządu terytorialnego, Wydawnictwo Uniwersytetu Ekonomicznego we Wrocławiu, Wrocław 2010, s. 193. 
komercyjną, obliczoną na pozyskanie dochodów budżetowych ${ }^{3}$. W to miejsce wprowadzono po wojnie rozbudowany i skomplikowany system transferów zewnętrznych w postaci subwencji ogólnej i dotacji celowej. Włączenie tej grupy środków do gospodarki finansowej samorządu ograniczyło jej samodzielność decyzyjną. Obecnie dochodowa samodzielność finansowa samorządów jest mniejsza od samodzielności wydatkowej.

Pierwszą kluczową zmianą systemową w dziedzinie finansów samorządu powinno być zwiększenie samodzielności finansowej w ramach procesu decentralizacji państwa, która w zakresie zadań już miała miejsce, lecz nie pociągnęła za sobą adekwatnego poziomu decentralizacji finansów ${ }^{4}$. W świetle postanowień Konstytucji $R P$ bazą finansów samorządu są dochody własne, zaś transfery zewnętrzne miały mieć charakter wspomagający, pomocniczy. Taka konstrukcja źródeł dochodów samorządu zapewnia stabilizację ich funkcjonowania, a tym samym zaspokajanie zbiorowych potrzeb ludności. W przeciwnym razie, powoduje dysfunkcje w gospodarce finansowej, które mogą skutkować poważnymi problema$\mathrm{mi}^{5}$, a w ostateczności doprowadzić nawet do likwidacji jednostki samorządowej.

Racjonalnym posunięciem byłaby zmiana struktury dochodów samorządu. Trwałą podwaliną gospodarowania w każdej jednostce są dochody własne, które powinny stanowić ok. 60-70\% dochodów ogółem. Osiągnięcie takiej wielkości wymaga zwiększenia jednego z głównych źródeł dochodów własnych: udziału w podatkach dochodowych od osób fizycznych i prawnych ${ }^{7}$. Stąd uzasadniona byłaby korekta w przepisach prawa, w celu wykluczenia finansowania zadań własnych samorządu, dotacjami z budżetu państwa. Rekompensata utraconego źródła dochodu może być wyrównana $\mathrm{w}$ dwojaki sposób. Po pierwsze, w proporcjonalnym zwiększeniu udziału w podatku dochodowym, po drugie, w odpowiednim zwiększeniu subwencji ogólnej (inny algorytm).

Wprowadzanie w ostatnich latach przez administrację rządową, instrumentów finansowania zadań samorządu w postaci różnych funduszy (np. dróg samorządowych, inwestycji lokalnych) nie gwarantuje jeszcze stabilności gospodarki finansowej. Po okresie redukowania liczby funduszy celowych, ponownie pomocnym źródłem finansowania wydatków majątkowych w samorządach lokalnych stały się fundusze tworzone na szczeblu centralnym. Ustawa z dnia 23 października 2018 r. o Funduszu Dróg Samorzadowych powołany został nowy mechanizm wsparcia dla samorządu, realizującego inwestycje na drogach lokalnych. Fundusz ten

3 A. Ginsbert-Gebert, Polityka komunalna..., s. 104.

4 Jak wynika z badań samodzielność mierzona udziałem dochodów własnych w dochodach budżetowych w większości jednostek samorządowych stanowią poniżej 50\%. Oznacza to, że głównym źródłem finansowania zadań samorządu są transfery zewnętrzne (subwencja i dotacje celowe).

5 Wdrażanie programów naprawczych.

6 Taka sytuacja miała już miejsce w gminie Ostrowice w województwie zachodniopomorskim.

7 Byłoby to rozwiązanie społecznie sprawiedliwe, ponieważ największym obciążeniem budżetów gospodarstw domowych są podatki pośrednie VAT i akcyza. 
stanowi instrument wsparcia realizacji zadań na drogach zarządzanych przez samorząd $^{8}$. Dofinansowanie z funduszu dla powiatów i gmin jest uzależnione od dochodów jednostek samorządu. Im niższy dochód własny, tym większa jest wartość dofinansowania, przy czym maksymalne dofinansowanie może wynieść do 80\% kosztów realizacji zadania9.

W 2020 r. powstał w ramach rządowego programu, kolejny nowy fundusz: Fundusz Inwestycji Lokalnych, nazywany potocznie „Tarczą inwestycyjną”, a źródłem jego finansowania jest Fundusz Przeciwdziałania COVID-19. Obejmuje on środki przeznaczone na dotacje dla gmin, miast na prawach powiatu i powiatów. Łącznie w skali całego kraju jest to $12 \mathrm{mld} \mathrm{zł,} \mathrm{z} \mathrm{czego} 5$ mld zł zostało przekazane według specjalnego algorytmu wszystkim gminom i miastom na prawach powiatu oraz $1 \mathrm{mld}$ zł powiatom ziemskim, na dopłaty do dowolnych inwestycji lokalnych. Pozostałe 6 mld zł zostanie rozdysponowane przez Prezesa Rady Ministrów na konkretne inwestycje proponowane przez jednostki samorządowe (bez województw). Środki będzie można wykorzystać np. na szkoły, przedszkola, wodociągi, drogi, tabor komunikacji miejskiej, szpitale, czy domy pomocy społecznej, a także inne działania podejmowane przez samorząd gminy i powiatu. Wymienione fundusze mają charakter doraźnej pomocy finansowej, w krótkim horyzoncie czasowym (np. fundusz inwestycji lokalnych - środki mają być wykorzystane do końca 2022 r.). Jak wcześniej zaznaczono, finansowanie funduszowe (tzw. środki celowane) ogranicza elastyczność działania samorządu i tym samym racjonalność wyborów. Transfery z budżetu państwa powinny pełnić funkcję uzupełniającą finansowania zadań samorządu. Dotacje celowe będą wtedy przekazywane tylko na zadania zlecone.

Podstawą prawną gospodarowania finansami samorządowymi są dwa kluczowe dokumenty: budżet i wieloletnia prognoza finansowa. Uwzględniając fakt, że prognoza posiada cechy i charakter planowania wieloletniego, powinna pełnić funkcję wiodącą w stosunku do budżetu. Wobec tego należałoby traktować ją jako podstawę do opracowania projektu budżetu (tak jak ma to miejsce w przypadku wieloletniego planu finansowego państwa). Wymaga to jednak kolejnej nowelizacji ustawy o finansach publicznych, w kierunku planowania średniookresowego

8 Jego celem jest przyspieszenie powstawania nowoczesnej i bezpiecznej infrastruktury drogowej na szczeblu lokalnym, stanowiącej ważny element prawidłowego funkcjonowania oraz rozwoju samorządu, przyczyniającego się do poprawy życia obywateli. Utworzenie tego funduszu ma również na celu poprawę bezpieczeństwa ruchu drogowego i parametrów technicznych lokalnej sieci drogowej, a także poprawę oraz zwiększenie atrakcyjności i dostępności terenów inwestycyjnych. Rozwój lokalnej infrastruktury drogowej stanowi przy tym działanie komplementarne do inicjatyw podejmowanych na szczeblu krajowym w odniesieniu do budowy systemu autostrad i dróg ekspresowych, przyczyniając się do stworzenia spójnego i zintegrowanego systemu transportowego.

9 W 2020 r. łączna wartość środków przeznaczonych na dofinansowanie inwestycji drogowych wynosi ok. $3 \mathrm{mld} 244 \mathrm{mln}$ zł. Na dofinansowanie zadań gminnych zaplanowano $1 \mathrm{mld}$ 474,3 mln zt, na zadania powiatowe - $1 \mathrm{mld} 269,6 \mathrm{mln}$ zt, zaś dofinansowanie zadań na drogach obronnych to ok. $500 \mathrm{mln}$ zt. 
(maksymalnie pięć lat - okres kadencji). Takie rozwiązania występują w samorządach wielu krajów Europy ${ }^{10}$.

Modyfikacji wymaga wieloletnia prognoza finansowa, z założenia mająca charakter strategiczny. W intencji ustawodawcy jest to wieloletni program finansowy obrazujący potencjalne zobowiązania samorządu w dłuższym czasie. Z kolei budżet jest dokumentem operacyjnym. Prognoza ta traktowana jest niesłusznie jako dokument wtórny (kroczący) wobec budżetu. Brak limitu czasu powoduje, że samorządy kierują się zbyt długim okresem planowania i opracowują prognozę na okres 20 lat i więcej. Ma ona wtedy niską przydatność, zwłaszcza że powinna być ciągle korygowana. Niektóre organy w samorządzie uważają, że sama prognoza gwarantuje niejako „z góry” odpowiednie środki finansowe w kolejnych latach. W związku z tym, podobnie jak na szczeblu centralnym (WPFP), prognoza w samorządzie powinna dotyczyć okresu kadencji organów władzy. Niezrozumiałe jest pozostawienie takiej dowolności w rękach tylko samorządu.

Sposób obliczania wskaźnika zadłużenia powoduje, że władze samorządowe poszukują rozwiązań pozaprawnych dla zaciągnięcia zobowiązań, nie uregulowanych w ustawie (spółki komunalne, tzw. kreatywna księgowość, parabanki itp.). Działania te grożą zakłóceniem bądź utratą płynności finansowej samorządów, powodując znaczny wzrost realnego zadłużenia oraz kosztu jego obsługi, który $\mathrm{w}$ istocie wymyka się spod kontroli ${ }^{11}$. Przykład wielu samorządów w Polsce pokazuje, że oferowanie relatywnie atrakcyjnych instrumentów przez różne instytucje finansowe grozi utratą stabilności gospodarki finansowej, w wyniku gwałtownego wzrostu długu. Przepisy prawa nie w pełni chronią interes publiczny, ponieważ jednoosobowy organ wykonawczy może w każdej chwili zaciągnąć zobowiązanie do kwoty akceptowanej w uchwale budżetowej przez organ stanowiący. Z dotychczasowych raportów Krajowej Rady Regionalnych Izb Obrachunkowych wynika, że regionalne izby obrachunkowe $\mathrm{w}$ ramach prowadzonego nadzoru są $\mathrm{w}$ istocie pozbawione skutecznych instrumentów nadzoru nad zastosowaniem niestandardowych narzędzi finansowania potrzeb samorządu.

\section{Zmiany usprawniające}

Mimo jawności gospodarki finansowej samorządu w tradycyjnym budżecie (ogólnie obowiązującym w świetle przepisów prawa) można oceniaćjedynie poprawność gromadzenia i wydatkowania środków publicznych. Ocena tylko finansowego poziomu wykonania poszczególnych zadań (szczególnie w działalności bieżącej) nie

10 W Finlandii przyjęto czteroletni okres planistyczny tego dokumentu, w Szwecji - trzy lata, Belgia i Portugalia - na okres kadencji, w Nowej Zelandii - dziesięcioletni okres planowania.

11 Poprzednie dwa progi ostrożnościowe w regulacji zadłużenia były bardziej przejrzyste i wiązały się z dużo mniejszym ryzykiem w procesie wykonywania zadań publicznych. 
wyeliminuje niegospodarności i marnotrawstwa. Dotyczy to przede wszystkim dużych jednostek, dysponujących znacznie większymi budżetami, w których łatwiej jest „ukryć" pewne zbędne koszty. Budżet w tej postaci nie stanowi skutecznego narzędzia pomiaru poniesionych wydatków, bowiem brak w nim danych o planowanych i osiągniętych efektach materialnych oraz społecznych lub ekologicznych.

Dobrym rozwiązaniem byłoby wprowadzenie w samorządach koncepcji performance budgeting, określanej jako budżetowanie zadaniowe. Rozliczenie $\mathrm{z}$ wymiernych rezultatów wskutek poniesionych wydatków na realizację poszczególnych zadań spowoduje wzrost odpowiedzialności i rozliczalności za gospodarkę środkami publicznymi. Budżet zadaniowy w polskim samorządzie uznawany jest nadal za nowy instrument gospodarki finansowej, który pozwala określić całkowity koszt realizacji zadania własnego wraz z jego efektami (mierniki). Jego budowa wymaga dużego wysiłku koncepcyjnego i organizacyjnego (na które nie stać mniejsze gminy) $)^{12}$. Celem tej formy budżetu jest większa przejrzystość i jawność, zwiększenie efektywności wydatkowania środków publicznych, koncentracja wydatków na zadaniach priorytetowych oraz realna wycena zadań publicznych (tzn. ile kosztują usługi komunalne?). Jego zastosowanie powinno być obligatoryjne. Opracowanie budżetu zadaniowego jest wymogiem dla administracji centralnej, natomiast w samorządzie przyjęto zasadę fakultatywności. Wymaga to poniesienia dodatkowego trudu dla administracji komunalnej, ponieważ musi ona przygotować budżet w dwóch wersjach: tradycyjnej (wymóg prawa) oraz zadaniowej. Budżet zadaniowy stanowi duże wyzwanie dla organu wykonawczego, gdyż z planowanych efektów będzie rozliczany po realizacji budżetu. Wykorzystanie tego instrumentu zarządzania finansami jest szczególnie ważne w dużych oraz w średnich samorządach i do tej pory znalazło zastosowanie w niewielu jednostkach.

Kontrowersyjne było wprowadzenie budżetu obywatelskiego jako instrumentu obligatoryjnego w miastach na prawach powiatu, zwłaszcza w warunkach kryzysu gospodarczego. Jego ideą jest bezpośrednie zaangażowanie mieszkańców w proces podejmowania decyzji, dotyczących wyboru zakresu zadań publicznych, w ramach wyznaczonej puli środków budżetowych i przejęcia części odpowiedzialności. Budżet obywatelski zaliczany jest do narzędzi innowacyjnych w sektorze publicznym. W rzeczywistości ma wymiar bardziej zmiany, nie tyle nowatorskiej, co proponującej inną logikę zagospodarowania wydzielonej części budżetu. Jest to idea zachęcająca do aktywności społecznej w rozwoju lokalnym, ale polska praktyka zaprzepaściła to. Obserwacja zastosowania tego budżetu, skłania do pewnych krytycznych ocen. Po pierwsze, podejmowane są inicjatywy z zakresu działalności bieżącej ${ }^{13}$, zamiast zadania inwestycyjnego, w którym

12 W tych gminach i tak w budżetach zachowana jest większa przejrzystość, niż w dużych samorządach.

13 Np. ustawienie koszy na śmieci, naprawa chodników, oświetlenia ulicznego, przycięcie lub posadzenie drzew, krzewów, naprawa urządzeń zabawowych, zwiększenie częstotliwości usług komunikacji miejskiej itp. 
chodzi o wskazanie priorytetów wśród potrzeb z punktu widzenia mieszkańców ${ }^{14}$. Po drugie, prowadzi do rozproszenia środków finansowych na małe projekty, które muszą być zrealizowane w cyklu rocznym. Budżet obywatelski ma niewiele wspólnego z efektywnością użycia środków finansowych i stanowi raczej koszt lekcji demokracji polegającej na społecznym wyborze pewnych kierunków działań ${ }^{15}$. Stosowana w Polsce wersja budżetu obywatelskiego wymaga modyfikacji w kierunku przygotowania propozycji zadań wraz z kosztami dla mieszkańców, którzy dokonają wyboru. Wydaje się, że zgłaszane przez mieszkańców propozycje zadań ${ }^{16}$, a następnie ich weryfikacja przez administrację są nie tylko czasochłonne, ale zbyt kosztowne (niektóre $\mathrm{z}$ nich są nierealne z przyczyn prawnych, technicznych, finansowych).

W gminach będących miastami na prawach powiatu utworzenie budżetu obywatelskiego jest obowiązkowe, a środki zaplanowane w ramach tego budżetu muszą stanowić minimum 0,5\% wydatków gminy, zawartych w ostatnim przedłożonym sprawozdaniu $\mathrm{z}$ wykonania budżetu ${ }^{17}$. W ten sposób, ustawodawca nie tylko narzucił obligatoryjność stosowania tego instrumentu określonej grupie jednostek, ale także nadał mu szczególną cechę w postaci wskazania minimalnej wysokości. W czasie, kiedy miasta i gminy tracą część dochodów z tytułu opłat i podatków oraz udzielają w różnych formach pomocy finansowej dla przedsiębiorców, jak też same ponoszą zwiększone wydatki w dobie pandemii, należałoby w pewnych zadaniach (działaniach) szukać oszczędności. Tymczasem przepisy prawa narzucają samorządom kolejne tzw. sztywne wydatki, wiążące się z nakładaniem nowych zadań lub rozszerzaniem zakresu istniejących zadań czy narzucaniem wdrażania określonego instrumentu (np. budżetu obywatelskiego). Narzędzie to powinno pozostać w gestii danej wspólnoty i być fakultatywne, a nie obowiązkowe. Oczywiście, takie decyzje mogą nie podobać się organizacjom pozarządowym uważającym, że budżety obywatelskie są niezwykle ważne dla społeczności lokalnych, bo służą poprawie jakości życia mieszkańców, budują społeczeństwo obywatelskie itd. Niemniej sama organizacja i przeprowadzanie procedury budżetu obywatelskiego już na etapie zbierania podpisów i promocji pomysłu, stanowi duże wyzwanie. Tam, gdzie budżet obywatelski nie jest obowiązkowy, samorządy gminne mają wyższą elastyczność działania w podejmowaniu racjonalnych decyzji w zakresie wydatkowania ograniczonych środków budżetowych.

Niezbędna jest jawność finansów w komunalnych jednostkach posiadających osobowość prawną. W Polsce rzadko dostępne są informacje dotyczące działalności tego typu podmiotów, które powinny być znane mieszkańcom wspólnoty. Informacje powinny obejmować dane o podstawowych wielkościach ekonomicznych

$14 \mathrm{~W}$ to miejsce cenne byłoby przedstawianie propozycji dotyczących innowacyjnego, nowatorskiego zagospodarowania przestrzeni publicznej.

15 E. Wojciechowski, Problem budżetu obywatelskiego, [w:] Aktualne problemy samorzqdu terytorialnego po 25 latach jego istnienia..., s. 375-382.

16 W dużych miastach liczba propozycji sięga nawet 1 tys.

17 Zgodnie z art. 5 a ust. 5 ustawy z dnia 8 marca 1990 r. o samorządzie gminnym... 
i finansowych charakteryzujących gospodarkę podmiotu, w tym wielkość zadłużenia. Zapewnia to większą czytelność i przejrzystość procesów decyzyjnych. Organy samorządowe powinny sprawować kontrolę nad procesem zadłużania się wszystkich podmiotów komunalnych i informować o tym mieszkańców. W przeciwnym razie, nadmierne zadłużenie obciąża przyszłe pokolenie i pozostaje w sprzeczności z zasadą zrównoważonego rozwoju. Do rozważenia pozostaje wprowadzenie wymogu „wyzerowania budżetu”, czyli zobowiązania do doprowadzenia do równowagi budżetowej w okresie np. 5-8 lat ${ }^{18}$ lub nałożenie limitu zadłużenia w kadencji (np. do $70 \%$ dochodów).

Wskazane jest również wprowadzenie nowych reguł finansowania oświaty. Warto rozważyć przekwalifikowanie zadania Oświata i wychowanie z charakteru własnego na zadanie zlecone przez administrację rządową. W obecnym stanie prawnym, samorząd nie ma pełnej samodzielnej zdolności do realizacji tego zadania. W swoich budżetach musi zabezpieczyć największą wysokość środków, bowiem gminy oraz powiaty ok. $30-35 \%$ wydatków przeznaczają na zadanie sklasyfikowane w dziale Oświata i wychowanie. Niedoskonałość algorytmu na podstawie którego dokonywany jest podział części oświatowej subwencji ogólnej wymaga zmian.

18 Wymóg ten istnieje np. samorządzie duńskim. 


\section{Zakończenie}

Analiza finansów samorządu terytorialnego w Polsce z punktu widzenia teoretyczno-poznawczego, prawnego i praktyki gospodarczej pozwala na sformułowanie wniosków końcowych o charakterze syntetycznym.

1. Gospodarowanie finansami samorządowymi stanowi część systemu jego funkcjonowania i rozwoju oraz lokalnej polityki społeczno-gospodarczej.

2. Przepisy prawne dotyczące finansów lokalnych są rozbudowane, rozproszone i w wielu aspektach niespójne. Kodyfikacja finansów samorządowych nie wchodzi w rachubę, ponieważ są one integralną częścią finansów publicznych.

3. Funkcjonowanie struktur samorządowych oraz zarządzanie finansami w samorządzie, przebiega pod przemożnym wpływem czynnika politycznego (organów samorządu). Zarządzający gospodarką komunalną pochodzą z wyborów i stanowią polityczne przedstawicielstwo społeczności lokalnej.

4. Jak wskazują badania, nie stworzono kompleksowego i wewnętrznie spójnego systemu finansowania działalności samorządu terytorialnego. Kwestia ta oprócz regulacji prawnych uznawana jest za drugie istotne źródło, utrudniające racjonalne i efektywne funkcjonowanie samorządu.

5. W Polsce od 1999 r. decentralizacja finansów nie nadąża za decentralizacją zadań publicznych. Ich delegowaniu na poziom samorządu nie zawsze towarzyszy przekazywanie odpowiednich środków finansowych ${ }^{1}$. Wprawdzie art. 167 Konstytucji $R P$ stanowi, że samorządowi terytorialnemu zapewnia się udział w dochodach publicznych odpowiednio do przypadających mu zadań, to często nie jest to respektowane. Spowodowało to mniejszy dopływ środków finansowych, przy jednoczesnym rozszerzeniu zakresu zadań bądź przekazywaniu nowych zadań bez adekwatnych nakładów.

6. Istnieje wiele czynników, które mają wpływ na niedofinansowanie samorządu terytorialnego. Można wskazać dwa podstawowe źródła tego niedoboru: niedofinansowanie zadań zleconych (wynikających z ustawy Prawo o aktach stanu cywilnego, jak też z ustawy Prawo geodezyjne i kartograficzne) oraz zbyt

1 Postanowienia EKSL, jak i Konstytucji RP gwarantują społeczności lokalnej prawo do dysponowania wystarczającymi (adekwatnymi) środkami finansowymi, z których część powinna pochodzić z podatków i opłat. 
niska subwencja w części oświatowej. Zadanie własne z zakresu oświaty i wychowania angażuje najwięcej środków budżetowych.

7. Samorządy gminne mają ograniczone władztwo podatkowe, zaś powiaty nie mają wcale takich uprawnień. Istnieje potrzeba pełniejszego władztwa podatkowego (np. bez narzucania górnego pułapu wysokości podatków lokalnych) ${ }^{2}$. Podatki lokalne, a zwłaszcza od nieruchomości i rolny (w gminach wiejskich), stanowią istotne źródło dochodów własnych gmin. Kwestia władztwa podatkowego odgrywa rolę jedynie w gminach, które realizują dominującą część zadań publicznych (ok. 80\%)ํ. Z drugiej strony, nadmierne zwiększanie samodzielności dochodowej może powodować pewne dysfunkcje: zbytni fiskalizm jednostek samorządowych czy znaczące dysproporcje w poziomie dochodów własnych.

8. Nie ma uzasadnienia ekonomicznego dla urynkowienia cen wszystkich usług komunalnych (np. pełna odpłatność za kulturę, komunikację miejską, gospodarka odpadami) w celu zwiększenia dochodów budżetowych. Może wtedy spaść na nie popyt, jak też pojawienie się większej grupy dłużników. Z istoty swej, usługi te mają charakter ogólnodostępny i zaspokajają podstawowe potrzeby bytowe.

9. Wprowadzenie w miejsce podatku od nieruchomości podatku katastralnego, zwiększyłoby dochody własne gmin, ale zdaniem autorki jest to przedwczesne, gdyż większości mieszkańców jeszcze na to nie stać ${ }^{4}$. Na świecie podatek ten stanowi kluczowe źródło dochodów samorządów gminnych, wymuszając m.in. porządek (ład) w gospodarce nieruchomościami. Wydaje się, że jest to „sprawiedliwy” podatek, ponieważ jest płacony nie od metrażu, lecz faktycznej wartości nieruchomości. Polska w miarę poprawy warunków ekonomicznych i bytowych powinna stopniowo podążać w tym kierunku.

10. W katalogu zadań komunalnych występują zadania, w które silnie integruje czynnik zewnętrzny (administracja centralna, prawo). Instytucje te określają bowiem kształt organizacyjny sposobu wykonywania tych zadań. Znajduje to wyraz w wielkości wydatków ponoszonych przez jednostki samorządowe. W ten sposób, tracą one autonomię finansową i samodzielność decyzyjną, prowadzącą do występowania niedoborów środków.

2 Jak wskazuje praktyka, ponad 90\% gmin i tak stosuje niższe stawki od ustalanych limitów.

3 Rozwiązanie to dotyczy zwłaszcza gmin, gdyż tylko ich władze mają ograniczone uprawnienia do ustalania wysokości poszczególnych podatków i opłat. Poza tym, wzrost dochodów własnych kosztem obciążenia mieszkańców wyższymi podatkami i opłatami winien się wiązać ze świadczeniem usług na wyższym poziomie. Inaczej mieszkańcy mogą wyrazić swoje niezadowolenie i chęć odwołania organu wykonawczego, który jest odpowiedzialny za realizację budżetu i to on zazwyczaj jest autorem projektu takich rozwiązań.

4 Dowodem na to może być brak pieniędzy na wykonanie przyłączy kanalizacyjnych lub wodociągowych nieruchomości prywatnych, mimo że gmina wybudowała taką sieć w drodze i zachęca do korzystania z niej. 
11. Dyskusje o nowym systemie finansowania jednostek samorządu powinny również uwzględniać uczestnictwo budżetu państwa w polityce wspierania najbiedniejszych samorządów. Ich możliwości finansowe są pochodną potencjału rozwojowego. Jednostki słabsze finansowo będą istnieć zawsze, stąd też $\mathrm{w}$ system finansów samorządowych wmontowany powinien być mechanizm redystrybucyjny (w miejsce tzw. janosikowego), umożliwiający pomoc najbiedniejszym $\mathrm{w}$ innej postaci jak dotychczas. Pomoc ta powinna pochodzić $\mathrm{z}$ budżetu państwa (obligatoryjnie), a nie z zamożnych samorządów (pomoc udzielana fakultatywnie) $)^{5}$.

12. Wskazane jest finansowanie hybrydowe (mieszane), polegające na łączeniu środków publicznych $\mathrm{z}$ kapitałem prywatnym. Poszukiwanie różnych źródeł finansowania działalności inwestycyjnej stanowi doniosłe wyzwanie dla wszystkich samorządów w Polsce w perspektywie malejących środków unijnych i zagrożeń płynących z międzynarodowej sytuacji gospodarczej. W większych samorządach trzeba będzie korzystać z instrumentów dłużnych (kredyty i pożyczki, obligacje itd.). Partnerstwo publiczno-prywatne należy traktować jako rozwiązanie komplementarne w finansowaniu przedsięwzięć gospodarczych przez samorząd. Partnerstwo uważane jest za aktywny przejaw współpracy międzysektorowej, niemniej ma ona zasięg ograniczony, przede wszystkim z powodu działalności użyteczności publicznej nie zorientowanej na zysk.

Przyjęta we wprowadzeniu teza, że dysfunkcje w gospodarowaniu zasobami majątkowymi w samorządzie wynikają nie tylko z niskiej jakości zarządzania, ale również z niedoboru środków finansowych, w świetle przeprowadzonej analizy teoretyczno-opisowej wydaje się wysoce prawdopodobna (potwierdziła się). Jak wskazują rozważania, źródła tych dysfunkcji tkwią w ułomnościach systemu finansowego samorządu oraz $\mathrm{w}$ czynniku ludzkim, spersonalizowanym przede wszystkim w organach władzy lokalnej i w służbach finansowych, które kształtują politykę finansową jednostek samorządowych. Może wystąpić sytuacja, kiedy system finansowy będzie zbudowany prawidłowo, a prowadzona polityka finansowa będzie nieracjonalna i mało skuteczna. I odwrotnie, duży wysiłek czynnika ludzkiego $\mathrm{w}$ zderzeniu $\mathrm{z}$ dysfunkcyjnym systemem finansowym samorządu, prowadzi do osiągania niższej efektywności ekonomicznej.

System finansów lokalnych dojrzewa do przebudowy przy założeniu poprawy jego funkcjonowania i efektywności. Warunkiem przebudowy systemów finansów lokalnych jest wola i determinacja czynnika politycznego na poziomie centralnym, zdecydowanego podjąć ryzyko przeprowadzenia zmian o różnych kierunkach i natężeniu. W dużym stopniu, proponowane rozstrzygnięcia nabierają kształtu prawnego, który powinien zapewnić stabilność warunków funkcjonowania i zaspokajania zbiorowych potrzeb ludności. Jeśli czynnik polityczny nie podejmie

5 Biedne gminy nie mają środków finansowych na zabezpieczenie wkładu własnego do projektów unijnych, przez co blokowane są inicjatywy rozwojowe. 


\section{Zakończenie}

takiego wyzwania na początku swojej kadencji, to system finansów nie zmieni się. Chociaż prawo zobowiązuje samorządy do racjonalnego (efektywnego) gospodarowania środkami budżetowymi, to przy niedoborze środków i trudnościach ich zdobywania - występuje i tak dużo marnotrawstwa oraz niegospodarności $\mathrm{w}$ wydatkowaniu pieniędzy publicznych. Takie działanie wiąże się z ewidentnym naruszaniem i omijaniem przepisów, a winni nie zawsze ponoszą za to odpowiedzialność. Powyższe propozycje są korzystne z punktu widzenia mieszkańców, którzy nie chcą płacić większych podatków i opłat lokalnych. 


\section{Bibliografia}

Babczuk A., Samodzielność finansowa jednostek samorządu terytorialnego. Pożadane kierunki zmian w świetle badań ankietowych, [w:] Finanse 2009 - Teoria i praktyka. Finanse publiczne II, Zeszyty Naukowe Uniwersytetu Szczecińskiego Nr 547, Szczecin 2009.

Begg D., Fisher S., Dornbush R., Ekonomia, t. 1, Państwowe Wydawnictwo Ekonomiczne, Warszawa 1995.

Bell Michael E. [w:] Lester M. Salamon, Robert A. Seidel, P. Bury, T. Markowski, Gospodarka samorzadów terytorialnych $w$ świetle doświadczeń amerykańskich, Fundacja Promocji Czystych Technologii TECHEKO, Łódź 1995.

Bitner M., Cichocki Krzysztof S., Sierak J., Standardy zarzadzania długiem na szczeblu lokalnym i regionalnym oraz ich wplyw na finansowanie infrastruktury, Instytut Badań Systemowych Polskiej Akademii Nauk, Warszawa 2013.

Bitner M., Prawne instrumenty ograniczenia deficytu budżetowego i długu publicznego jednostek samorządu terytorialnego, Wolters Kluwer, Warszawa 2016.

Bogdanienko J., Zarys koncepcji, metod i problemów zarządzania, Dom Organizatora, Toruń 2020.

Borodo A., Polskie prawo finansowe. Zarys ogólny, Wydawnictwo TNOiK, Toruń 2005.

Borodo A., System finansowy samorzadu terytorialnego w Polsce, Dom Organizatora, Toruń 2011.

Buchanan James M., Finanse publiczne w warunkach demokracji, Wydawnictwo Naukowe PWN, Warszawa 1997.

Chojna-Duch E., Zagadnienie długu jednostek samorzadu terytorialnego - nowe propozycje prawne, „Samorząd Terytorialny” 2008, nr 11.

Czaja S., Becla A., Ekologiczne podstawy procesów gospodarowania, Wydawnictwo Akademii Ekonomicznej we Wrocławiu, Wrocław 2007.

Czarny B., Podstawy ekonomii, Polskie Wydawnictwo Ekonomiczne, Warszawa 2011.

Dafflon B., Beer-Toth K., Managing local public debt in transition countries: An issue of self-control. Paper prepared for the 14 th Annual Conference of the Networkof Institutions and Schools of Public Administration in Central and Eastern Europe (NISPAcee), Ljubljana, May 11-13, 2006.

Dolewka Z., Budżet zadaniowy w gminach jako nowe narzędzie zarządzania finansami samorządowymi, [w:] Budżet zadaniowy metoda racjonalizacji wydatków, (red.) B. Woźniak, M. Postuła, Wydawnictwo CeDeWu, Warszawa 2012. 
Dolewka Z., Dokumenty planistyczne i sprawozdawcze do oceny kondycji finansowej gminy, [w:] Finanse i ryzyko w kształtowaniu rozwoju regionu, (red.) M. Dylewski, Zeszyty Naukowe Wyższej Szkoły Bankowej w Poznaniu, nr 41, Poznań 2012.

Dolewka Z., System kontroli i nadzoru w samorzadzie terytorialnym, „Biblioteka Regionalisty" 2013, nr 13.

Dolewka Z., Wieloletnia prognoza finansowa jako instrument zarzadzania finansami samorządowymi, [w:] Aktualne problemy samorzadu terytorialnego po 25 latach jego istnienia, (red.) Ryszard P. Krawczyk, A. Borowicz, Wydawnictwo Uniwersytetu Łódzkiego, Łódź 2016.

Dolewka Z., Zarządzanie w jednostkach organizacyjnych gminy, [w:] Efektywność zarządzania organizacjami publicznymi i jej pomiar, (red.) A. Frączkiewicz-Wronka, Zeszyty Naukowe Wydziałowe Uniwersytetu Ekonomicznego w Katowicach, Katowice 2013.

Dylewski M., Nadwyżka operacyjna a decyzje finansowe jednostek samorząu terytorialnego, „Oeconomia” nr 6, Uniwersytet Marii Curie-Skłodowskiej, Lublin 2017.

Dylewski M., Planowanie budżetowe w podsektorze samorzadowym. Uwarunkowania, procedury, modele, Wydawnictwo Difin, Warszawa 2007.

Dylewski M., Problemy wykorzystywania WPF w zarzadzaniu finansami jednostki samorządu terytorialnego, Studia Ekonomiczne, Zeszyty Naukowe Uniwersytetu Ekonomicznego w Katowicach nr 273, Katowice 2016.

Dylewski M., Filipiak B., Gorzałczyńska-Koczkodaj M., Analiza finansowa w jednostkach samorzadu terytorialnego, Wydawnictwo Municipium, Warszawa 2004.

Dziekański P., Analiza sytuacji finansowej samorzadu jako wyznacznik efektywności ekonomicznej jednostek samorządu terytorialnego, [w:] Finanse publiczne i rozwój przedsiębiorczości w regionach (red.) B. Filipiak, Wydawnictwo Wyższej Szkoły Bankowej w Poznaniu, Poznań 2011.

Filipiak B., Dylematy pomiaru potencjału finansowego jednostek samorzadu terytorialnego - dobór czynników i ich pomiar, Prace Naukowe Uniwersytetu Ekonomicznego we Wrocławiu nr 451, Wrocław 2016.

Filipiak B., Efektywność w zarządzaniu finansami samorzadowymi. Skutek kryzysu czy obiektywna konieczność?, Polskie Towarzystwo Ekonomiczne, Zeszyty Naukowe Nr 10, Kraków 2011.

Filipiak B., Finanse samorządowe. Nowe wyzwania bieżace i perspektywiczne, Wydawnictwo Difin 2011.

Filipiak B., Indywidualny wskaźnik zadłużenia jako determinanta oceny kondycji finansowej jednostki samorządu terytorialnego, „Nierówności Społeczne a Wzrost Gospodarczy" 2018, nr 56.

Filipiak B., Kierunki zarządzania finansami w jednostkach samorzadu terytorialnego a problemy utrzymania płynności finansowej, „Finanse Komunalne” 2004, nr 3.

Filipiak B., Metodyka kompleksowej oceny gospodarki finansowej jednostki samorzadu terytorialnego, Wydawnictwo Difin, Warszawa 2009. 
Filipiak B., Strategia podatkowa władz samorzadowych jako czynnik stymulujący rozwój lokalny, [w:] Przestrzeń w nowych realiach gospodarczych, (red.) S. Korenik, P. Hajduga, M. Rogowska, Prace Naukowe Uniwersytetu Ekonomicznego we Wrocławiu Nr 408, Wrocław 2015.

Ginsbert-Gebert A., Polityka komunalna, Państwowe Wydawnictwo Ekonomiczne, Warszaw 1984.

Grzymała Z. (red.), Wydatki na ustugi komunalne w strukturze wydatków mieszkańców gmin - ocena w układzie regionalnym, Oficyna Wydawnicza Szkoła Główna Handlowa w Warszawie, Warszawa 2015.

Gubernat-Ulatowski E., Potencjał finansowy i inwestycyjny a aktywność inwestycyjna jednostek samorzadu terytorialnego, Zeszyty Naukowe Uniwersytetu Ekonomicznego w Katowicach, nr 294, Katowice 2016.

Guziejewska B., Finanse publiczne wobec wyzwań globalizacji, Wydawnictwo Poltext, Warszawa 2010.

Guziejewska B., Zewnętrzne źródła finansowania samorząu terytorialnego. Teoria i praktyka, Wydawnictwo Uniwersytetu Łódzkiego, Łódź 2008.

Hanus L., Wieloletnia prognoza finansowa jednostek samorzadu terytorialnego, „Finanse Publiczne" 2010, nr 8.

Hanusz A., Niezgoda A., Czerski P., Dochody budżetu jednostek samorządu terytorialnego, Oficyna a Wolters Kluwer business, Warszawa 2009.

Harańczyk A., Samorząd terytorialny. Organizacja i gospodarka, Wydawnictwo Uniwersytetu Ekonomicznego w Krakowie, Kraków 2010.

Jastrzębska M., Jawność i przejrzystość sprawozdawczości jednostek samorządu terytorialnego - ocena i rekomendacje, „Nierówności Społeczne a Wzrost Gospodarczy" 2018, nr 56.

Jastrzębska M., Wybór instrumentu zwrotnego finansowania $w$ celu realizacji inwestycji samorzadowych, Zeszyty Naukowe Uniwersytetu Szczecińskiego Nr 530, Szczecin 2009.

Kluza B., Kluza K., Mieszkania komunalne - wyzwania dla polityki mieszkaniowej państwa w świetle badań wybranych miast, „Urban Development Issues” 2020, volume 67.

Kluza K., Efektywność polskich jednostek samorządu terytorialnego na tle samorzadów Unii Europejskiej - weryfikacja adekwatności dochodów, „Finanse Komunalne" 2014, nr 12.

Kluza K., Wpływ zmian w ustawie o finansach publicznych na koszt finansowania samorzadów, „Zarządzanie i Finanse” 2013, nr 3.

Kluza K., Zadłużenie jednostek samorzadu terytorialnego w Polsce. Trendy historyczne, narzędzia do analizy zdolności spłaty zadłużenia oraz postulaty zmian systemowych, Instytut Rozwoju Miast i Regionów, Warszawa 2019.

Kornberger-Sokołowska E., Wskaźnik zadłużenia a uwarunkowania funkcjonowania jednostek samorzadu terytorialnego $w$ warunkach zmiennej koniunktury gospodarczej, „Finanse Komunalne” 2015, nr 1-2. 
Kosek-Wojnar M., Surówka K., Podstawy finansów samorządu terytorialnego, Wydawnictwo Naukowe PWN, Warszawa 2007.

Kosikowski C., Finanse lokalne. Zarys wykładu, Wyższa Szkoła Finansów i Zarządzania w Siedlcach, Siedlce 2001.

Kosikowski C., Pojęcie i charakter prawny budżetu państwa, [w:] Finanse publiczne i prawo finansowe, (red.) C. Kosikowski, E. Ruśkowski, Wydawnictwo Wolters Kluwer business, Warszawa 2008.

Kozuń-Cieślak G., Budżetowanie w jednostkach samorządu terytorialnego - reorientacja z administrowania na zarządzanie, „Finanse Komunalne” 2010, nr 9.

Krajowa Rady Regionalnych Izb Obrachunkowych, Sprawozdanie z działalności regionalnych izb obrachunkowych $i$ wykonania budzetu przez jednostki samorzadu terytorialnego w 2015 r., Warszawa 2016.

Krawczyk Ryszard P., Samodzielność w praktyce działania samorządu terytorialnego oraz w orzecznictwie Trybunału Konstytucyjnego, [w:] Aktualne problemy samorzadu terytorialnego po 25 latach jego istnienia, (red.) Ryszard P. Krawczyk, A. Borowicz, Wydawnictwo Uniwersytetu Łódzkiego, Łódź 2016.

Krugman P., Wells R., Mikroekonomia, Wydawnictwo Naukowe PWN, Warszawa 2013.

Kudłacz T., Finansowe aspekty polityki przestrzennej samorządów terytorialnych, [w:] Zrozumieć terytorium. Idea i praktyka, (red.) A. Nowakowska, Wydawnictwo Uniwersytetu Łódzkiego, Łódź 2013.

Kuzyniak E., Wirtualne dochody nie rozwiąża problemów wskaźnika zadłużenia, „Wspólnota” 2013, nr 20.

Lubińska T. (red.), Nowe zarzadzanie publiczne - skuteczność i efektywność. Budżet zadaniowy w Polsce, Wydawnictwo Difin, Warszawa 2009.

Lubińska T., Budżet państwa i budżet zadaniowy w kontekście zasad budżetowych, [w:] Budżet zadaniowy metoda racjonalizacji wydatków, (red.) B. Woźniak, M. Postuła, Wydawnictwo CeDeWu, Warszawa 2012.

Łyszkiewicz M., Gospodarowanie majątkiem komunalnym. Zasady, metody, strategie, Wydawnictwo CeDeWu, Warszawa 2016.

Markowski T., Budowanie regulacyjnego systemu planowania przestrzennego. Teoria sprawiedliwości podstawa budowy systemu, [w:] Przestrzeń dobrem publicznym - potrzeba nowych rozwiązań w gospodarowaniu przestrzenia, Najwyższa Izba Kontroli, Warszawa 2016.

Markowska-Bzducha E., Rola samorzadu terytorialnego w kreowaniu rozwoju lokalnego i regionalnego - samorzadowe wydatki inwestycyjne, Prace Naukowe Uniwersytetu Ekonomicznego we Wrocławiu, nr 101, Wrocław 2010.

Mażewski L., Zmiany w budżecie JST, „Gazeta Samorządu i Administracji” 2016, nr 4.

Milewski R. (red.), Podstawy ekonomii, Wydawnictwo Naukowe PWN, Warszawa 1998.

Ministerstwo Finansów, Nadwyżka operacyjna w jednostkach samorządu terytorialnego w latach 2007-2009, Warszawa 2010. 
Misiąg W., Rola inwestycji w budżecie państwa i w budżetach gmin, Instytut Badań nad Gospodarką Rynkową, Warszawa 1997.

Misiąg W., Niedzielski A., Jawność i przejrzystość finansów publicznych $w$ Polsce $w$ świetle standardów Międzynarodowego Funduszu Walutowego, Zeszyty Instytutu Badań nad Gospodarką Rynkową, Warszawa 2001, nr 29.

Miszczuk A., Miszczuk M., Żuk K., Gospodarka samorządu terytorialnego, Wydawnictwo Naukowe PWN, Warszawa 2007.

Możdżeń M., Instytucje polityczne i proces budżetowy. Przeciwdziałanie tragedii wspólnych zasobów fiskalnych, Wydawnictwo Naukowe Scholar, Warszawa 2018.

Nowak Maciej J., Mienie komunalne, „Gazeta Samorządu i Administracji” 2016, nr 9.

Olejniczak-Szałowska E., Samorzad terytorialny w Europie Zachodniej, [w:] Samorzad terytorialny. Podstawowe zagadnienia, (red.) M. Stahl, E. Olejniczak-Szałowska, Fundacja Rozwoju Demokracji Lokalnej, Warszawa 1994.

Owsiak S., Finanse publiczne. Teoria i praktyka, Wydawnictwo Naukowe PWN, Warszawa 1999.

Owsiak S., Finanse publiczne. Teoria i praktyka, Wydawnictwo Naukowe PWN, Warszawa 2005.

Owsiak S., Finanse publiczne. Teoria i praktyka, Wydawnictwo Naukowe PWN, Warszawa 2017.

Owsiak S., Kosek-Wojnar M., Surówka K., Równowaga budżetowa: deficyt budżetowy, dług publiczny, Wydawnictwo Naukowe PWN, Warszawa 1993.

Patrzałek L., Finanse samorządu terytorialnego, Wydawnictwo Uniwersytetu Ekonomicznego we Wrocławiu, Wrocław 2010.

Piasecki Andrzej K., Samorząd terytorialny i wspólnoty lokalne, Wydawnictwo Naukowe PWN, Warszawa 2009.

Pietrzak B., Polański Z., Woźniak B., System finansowy w Polsce, tom 2, PWN, Warszawa 2008.

Piotrowska-Marczak K., Finanse lokalne w Polsce, Wydawnictwo Naukowe PWN, Warszawa 1997.

Poniatowicz M., Dług publiczny w systemie finansowym jednostek samorządu terytorialnego, Wydawnictwo Uniwersytetu w Białymstoku, Białystok 2005.

Poniatowicz M., Koncepcja federalizmu fiskalnego $w$ systemie finansów samorzadu terytorialnego, Wydawnictwo CeDeWu, Warszawa 2018.

Postuła M., Aktualne doświadczenia Austrii we wprowadzaniu budżetu zadaniowego, [w:] Budżet zadaniowy metoda racjonalizacji wydatków, (red.) B. Woźniak, M. Postuła, Szkoła Główna Handlowa w Warszawie, Warszawa 2012.

Postuła M., Zasadnicze działania w obszarze nowego zarzadzania finansami publicznymi w Polsce, [w:] Finanse 2009 - Teoria i praktyka. Finanse publiczne I, Zeszyty Naukowe Uniwersytetu Szczecińskiego Nr 546, Szczecin 2009.

Przygodzka R., Władztwo podatkowe a stabilność finansowa gmin, „Nierówności Społeczne a Wzrost Gospodarczy" 2014, nr 4.

Puszkarska A., Zasady zarządzania mieniem komunalnym, „Rzeczpospolita” z 17 lipca 2018 r. 
Richardson B., Richardson R., Business Planning. An Approach to Strategic Management, PITMAN Publishing, London 1992.

Rudzka-Lorentz Cz., Sierak J., Zarządzanie finansami w gminach, [w:] Zarządzanie gospodarka i finansami gmin, (red.) H. Sochacka-Krysiak, Szkoła Główna Handlowa w Warszawie, Warszawa 2006.

Ruśkowski E., Finanse i prawo finansowe, Wydawnictwo „KiK”, Warszawa 1994, s. 261.

Ruśkowski E., Finanse samorządu regionalnego i lokalnego, [w:] Gospodarka regionalna i lokalna, Wydawnictwo Naukowe PWN, Warszawa 2008.

Sierak J., Analiza wskaźnikowa a model zarządzania jednostka samorzadu terytorialnego, [w:] Gospodarka lokalna $i$ regionalna $w$ teorii i praktyce, Prace Naukowe Akademii Ekonomicznej we Wrocławiu nr 1083, Wrocław 2005.

Sierak J., Finansowanie inwestycji gmin instrumentami dłużnymi - szanse i zagrożenia, „Nierówności Społeczne a Wzrost Gospodarczy” 2018, nr 56.

Sierak J., Komunalna luka infrastrukturalna a możliwości budżetowe gmin w jej ograniczaniu, Oficyna Wydawnicza SGH, Szkoła Główna Handlowa, Warszawa 2019.

Sierak J., Regionalne zróżnicowanie wielkości i dynamiki dochodów gmin i miast na prawach powiatu - analiza wskaźnikowa dla lat 2000-2014, „Finanse Komunalne" 2017, nr 1-2.

Sobol E., Nowy słownik języka polskiego, Wydawnictwo Naukowe PWN, Warszawa 2002.

Sochacka-Krysiak H. (red.), Gospodarka finansowa jednostek terytorialnego w warunkach decentralizacji zarządzania sektorem publicznym, Szkoła Główna Handlowa w Warszawie, Warszawa 2008.

Sochacka-Krysiak H., Decentralizacja terytorialna $w$ świetle Europejskiej Karty Samorzadu Terytorialnego, [w:] Gospodarka finansowa jednostek samorzadu terytorialnego $w$ warunkach decentralizacji zarządzania sektora publicznego, (red.) H. Sochacka-Krysiak, Szkoła Główna Handlowa w Warszawie, Warszawa 2008.

Standar A., Ocena kondycji finansowej gmin oraz jej wybranych uwarunkowań na przykładzie województwa wielkopolskiego przy wykorzystaniu metody TOPSIS, „Wieś i Rolnictwo” 2017, nr 2.

Stęszewski M., Wieloletnia prognoza finansowa jednostki samorządu terytorialnego, „Biuletyn Skarbowy Ministerstwa Finansów” 2008, nr 2.

Stiglitz Joseph E., Ekonomia sektora publicznego, Wydawnictwo Naukowe PWN, Warszawa 2004.

Strzelecki Z. (red.), Gospodarka lokalna i regionalna, Wydawnictwo Naukowe PWN, Warszawa 2008.

Surówka K., Problem oceny poziomu zadłużenia jednostek samorządu terytorialnego a realizacja zadań, „Finanse Komunalne” 2014, nr 9.

Surówka K., Rola nadwyżki operacyjnej w finansowaniu działalności rozwojowej jednostek samorzadu terytorialnego i zaspokajaniu potrzeb społecznych (na przykładzie gmin oraz miast na prawach powiatu w latach 2011-2017), „Finanse Komunalne" 2018, nr 7-8. 
Surówka K., Samodzielność finansowa samorząu terytorialnego w Polsce, Polskie Wydawnictwo Ekonomiczne, Warszawa 2013.

Surówka K., Owsiak K., Administrowanie czy rozwój - 20 lat doświadczeń finansowania polskiego samorządu terytorialnego, „Nierówności Społeczne a Wzrost Gospodarczy” 2018, nr 56.

Swianiewicz P., Finanse samorządowe. Koncepcja, realizacja, polityki lokalne, Wydawnictwo Municipium, Warszawa 2011.

Szewczuk A., Strategie gospodarowania środkami publicznymi w jednostkach samorządu terytorialnego na tle ujawniajacych się zjawisk kryzysowych, [w:] Finanse 2009 - Teoria i praktyka. Finanse publiczne II, Zeszyty Naukowe Uniwersytetu Szczecińskiego Nr 547, Szczecin 2009.

Taylor E., Historia rozwoju ekonomiki, t. 1, Państwowe Wydawnictwo Naukowe, Warszawa 1957.

Wakuła M., Wybrane problemy zarzadzania finansami gmin, Zeszyty Naukowe Akademii Podlaskiej w Siedlcach, nr 82, Siedlce 2009.

Wartalska M., Wybrane przesłanki budowy programów zarządzania majątkiem komunalnym $w$ aspekcie gospodarowania finansami miasta, [w:] Konkurencyjność $i$ potencjał rozwoju polskich metropolii - szanse $i$ bariery, „Biuletyn Komitetu Przestrzennego Zagospodarowania Kraju PAN”, z. 214, Warszawa 2004.

Wąsik J., Wydatki budżetowe a koszty realizacji zadań w budżecie zadaniowym, [w:] Budżet zadaniowy metoda racjonalizacji wydatków, (red.) B. Woźniak, M. Postuła, Szkoła Główna Handlowa w Warszawie, Warszawa 2012.

Wiewióra M., Wpływ nadwyżki operacyjnej budżetu na kondycje finansowa jednostki samorządu terytorialnego, „Studia i Prace Kolegium Zarządzania i Finansów” 2008, z. 86.

Wilczyński W., Rachunek ekonomiczny a mechanizm rynkowy, Państwowe Wydawnictwo Naukowe, Warszawa 1965.

Wojciechowski E., Ekonomiczne oblicze samorzadu terytorialnego, [w:] Finanse i ryzyko w kształtowaniu rozwoju regionu, (red.) M. Dylewski, Zeszyty Naukowe Wyższej Szkoły Bankowej w Poznaniu, nr 41, Poznań 2012.

Wojciechowski E., Gospodarka samorzadu terytorialnego, Wydawnictwo Difin, Warszawa 2012.

Wojciechowski E., Problem budżetu obywatelskiego, [w:] Aktualne problemy samorzadu terytorialnego po 25 latach jego istnienia, (red.) Ryszard P. Krawczyk, A. Borowicz, Wydawnictwo Uniwersytetu Łódzkiego, Łódź 2016.

Wojciechowski E., Samorząd terytorialny w warunkach gospodarki rynkowej, Wydawnictwo Naukowe PWN, Warszawa 1997.

Wojciechowski E., Zarządzanie w samorządzie terytorialnym, wydanie drugie poprawione i rozszerzone, Wydawnictwo Difin, Warszawa 2012.

Wojciechowski M., Koszt władzy w polskim samorządzie terytorialnym, Wydawnictwo Difin, Warszawa 2014. 
Zalewski A., Problemy i metody prognozowania wplywu rozwoju lokalnego na finanse gminy, [w:] Gospodarka lokalna i regionalna w teorii i praktyce, Prace Naukowe Uniwersytetu Ekonomicznego we Wrocławiu nr 46, Wrocław 2009.

Zioło M., Aktywność inwestycyjna samorządu terytorialnego w Polsce w latach 1999-2005, [w:] Harmonizacja finansów publicznych w skali narodowej i europejskiej, (red.) K. Piotrkowska-Marczak, K. Kietlińska, Wydawnictwo Difin, Warszawa 2007.

\section{AKTY PRAWNE}

Code of Good Practices on Fiscal Transparency - Declaration of Principles (Dziennik Urzędowy Unii Europejskiej C 384, 10/12/1998).

Europejska Karta Samorządu Lokalnego sporządzona w Strasburgu dnia 15 października 1985 r. (Dz. U. z 1994 r. Nr 124, poz. 607 ze zm.).

Konstytucja Rzeczypospolitej Polskiej z dnia 2 kwietnia 1997 r. (Dz. U. z 1997 r. $\mathrm{Nr} 78$, poz. 483 ze zm.).

Ustawa z dnia 26 października 1982 r. o wychowaniu w trzeźwości i przeciwdziałaniu alkoholizmowi (tekst jednolity: Dz. U. z 2019 r., poz. 2277 ze zm.).

Ustawa $z$ dnia 8 marca 1990 r. o samorzadzie gminnym (tekst jednolity: Dz. U. z 2020 r., poz. 506 ze zm.).

Ustawa z dnia 12 stycznia 1991 r. o podatkach i opłatach lokalnych (tekst jednolity: Dz. U. z 2019 r., poz. 1170).

Ustawa $z$ dnia 7 października 1992 r. o regionalnych izbach obrachunkowych (tekst jednolity: Dz. U. z 2019 r., poz. 2137).

Ustawa z dnia 29 września 1994 r. o rachunkowości (tekst jednolity: Dz. U. z 2021 r., poz. 217).

Ustawa $z$ dnia 23 grudnia 1994 r. o Najwyższej Izbie Kontroli (tekst jednolity: Dz. U. z 2020 r., poz. 1200 ze zm.).

Ustawa z dnia 13 września 1996 r. o utrzymaniu czystości i porządku w gminach (tekst jednolity: Dz. U. z 2020 r., poz. 1439).

Ustawa $z$ dnia 20 grudnia 1996 r. o gospodarce komunalnej (tekst jednolity: Dz. U. z 2019 r., poz. 712 ze zm.).

Ustawa $z$ dnia 21 sierpnia 1997 r. o gospodarce nieruchomościami (tekst jednolity: Dz. U. z 2020 r., poz. 1990 ze zm.).

Ustawa $z$ dnia 5 czerwca 1998 r. o samorzadzie powiatowym (tekst jednolity: Dz. U. z 2020 r., poz. 920).

Ustawa $z$ dnia 5 czerwca 1998 r. o samorządzie województwa (tekst jednolity: Dz. U. z 2020 r., poz. 1668).

Ustawa z dnia 6 września 2001 r. o dostępie do informacji publicznej (tekst jednolity: Dz. U. z 2019 r., poz. 1429 ze zm.).

Ustawa z dnia 13 listopada 2003 r. o dochodach jednostek samorzadu terytorialnego (tekst jednolity: Dz. U. z 2020 r., poz. 23 ze zm.).

Ustawa $z$ dnia 29 stycznia 2004 r. Prawo zamówień publicznych (tekst jednolity: Dz. U. z 2019 r., poz. 1843 ze zm.). 
Ustawa $z$ dnia 27 sierpnia 2009 r. o finansach publicznych (tekst jednolity: Dz. U. z 2019 r., poz. 869 ze zm.).

Ustawa $z$ dnia 11 stycznia 2018 r. o zmianie niektórych ustaw w celu zwiększenia udziału obywateli $w$ procesie wybierania, funkcjonowania $i$ kontrolowania niektórych organów publicznych (Dz. U. z 2018 r., poz. 130). 

Załączniki 
Tabela 4. Wielkość dochodów budżetowych jednostek samorządu terytorialnego (w tys. zł)

\begin{tabular}{|c|c|c|c|c|c|c|c|}
\hline Treść & 1995 & 1997 & 1999 & 2001 & 2003 & 2005 & 2007 \\
\hline \multicolumn{8}{|c|}{ Gminy tącznie z miastami na prawach powiatu } \\
\hline Dochody & 19993435 & 39518248 & 51741684 & 60954011 & 63463079 & 82082991 & 103876554 \\
\hline wtasne & 8011650 & 13937359 & 26388257 & 29963212 & 31393490 & 43937126 & 57337271 \\
\hline subwencja & 3042376 & 9541912 & 16604199 & 21343860 & 23981684 & 24405800 & 27192523 \\
\hline dotacje & 8939409 & 16038977 & 8749228 & 9646939 & 8087905 & 13740065 & 19346760 \\
\hline \multicolumn{8}{|c|}{ Gminy bez miast na prawach powiatu } \\
\hline Dochody & 12696332 & 26371041 & 32353486 & 37286893 & 36046322 & 45813191 & 57003129 \\
\hline wtasne & 5470794 & 9535853 & 17053415 & 18807190 & 16112075 & 20558189 & 26535492 \\
\hline subwencja & 1918536 & 7492222 & 10877443 & 13509253 & 15217593 & 16080320 & 17865572 \\
\hline dotacje & 5307002 & 9342966 & 4422628 & 4970450 & 4716654 & 9174682 & 12602065 \\
\hline \multicolumn{8}{|c|}{ Miasta na prawach powiatu } \\
\hline Dochody & 7297103 & 13147207 & 19388198 & 23667118 & 27416757 & 36269800 & 46873425 \\
\hline wtasne & 2540856 & 4401506 & 9334842 & 11156022 & 15281415 & 23378937 & 30801779 \\
\hline subwencja & 1123840 & 2049690 & 5726756 & 7834607 & 8764091 & 8325480 & 9326951 \\
\hline dotacje & 3632407 & 6696011 & 4326600 & 4676489 & 3371251 & 4565383 & 6744695 \\
\hline \multicolumn{8}{|c|}{ Powiaty } \\
\hline Dochody & - & - & 9847402 & 14041104 & 11111621 & 13762684 & 16154756 \\
\hline wtasne & - & - & 604829 & 1171470 & 1159545 & 3737665 & 4784610 \\
\hline subwencja & - & - & 4371624 & 6503873 & 6236453 & 6699491 & 7445258 \\
\hline dotacje & - & - & 4870949 & 6365761 & 3715623 & 3325528 & 3924888 \\
\hline \multicolumn{8}{|c|}{ Województwa } \\
\hline Dochody & - & - & 3288427 & 4599534 & 4565750 & 7066206 & 11348892 \\
\hline wtasne & - & - & 583058 & 611922 & 704849 & 4416728 & 6571596 \\
\hline subwencja & - & - & 1140634 & 1582237 & 1510435 & 1350458 & 2116070 \\
\hline dotacje & - & - & 1564735 & 2405375 & 2350466 & 1299020 & 2661226 \\
\hline \multicolumn{8}{|c|}{ Ogółem jednostki samorządu terytorialnego } \\
\hline Dochody & 19993435 & 39518248 & 64877513 & 79594649 & 79140450 & 102911881 & 131380202 \\
\hline wtasne & 8011650 & 13937359 & 27576144 & 31746604 & 33257884 & 52091519 & 68693477 \\
\hline subwencja & 3042376 & 9541912 & 22116457 & 29429970 & 31728572 & 32455749 & 36753851 \\
\hline dotacje & 8939409 & 16038977 & 15184912 & 18418075 & 14153994 & 18364613 & 25932874 \\
\hline
\end{tabular}




\begin{tabular}{|c|c|c|c|c|c|c|c|}
\hline $\mathbf{2 0 0 9}$ & $\mathbf{2 0 1 1}$ & $\mathbf{2 0 1 3}$ & $\mathbf{2 0 1 5}$ & $\mathbf{2 0 1 7}$ & $\mathbf{2 0 1 8}$ & $\mathbf{2 0 1 9}$ \\
\hline \multicolumn{7}{|c|}{ Gminy tącznie z miastami na prawach powiatu } \\
\hline 115209656 & 132690457 & 144260001 & 158227339 & 189718825 & 206933388 & 229055896 \\
\hline 63284005 & 70441681 & 78604774 & 88347043 & 96388860 & 104941586 & 113544905 \\
\hline 33291629 & 35750737 & 38340297 & 39301019 & 41891559 & 43742811 & 47538100 \\
\hline 18634022 & 26498039 & 27314930 & 30579277 & 51438406 & 58248991 & 67972891 \\
\hline
\end{tabular}

\section{Gminy bez miast na prawach powiatu}

\begin{tabular}{|r|r|r|r|r|r|r|}
\hline 64882149 & 75830680 & 80043418 & 87667235 & 111189285 & 121425597 & 135161525 \\
\hline 30021854 & 34489930 & 38545969 & 43573324 & 48076250 & 52530327 & 58484106 \\
\hline 21989242 & 23267552 & 24793102 & 25419374 & 27071097 & 28359271 & 30420065 \\
\hline 12871053 & 18073198 & 16704347 & 18674537 & 36041938 & 40535999 & 46257354 \\
\hline
\end{tabular}

Miasta na prawach powiatu

\begin{tabular}{|r|r|r|r|r|r|r|}
\hline 50327507 & 56859777 & 64216583 & 70560104 & 78529540 & 85507791 & 93894371 \\
\hline 33262151 & 35951751 & 40058805 & 44773719 & 48312610 & 52411259 & 55060799 \\
\hline 11302387 & 12483185 & 13547195 & 13881645 & 14820462 & 15383540 & 17118035 \\
\hline 5762969 & 8424841 & 10610583 & 11904740 & 15396468 & 17712992 & 21715537 \\
\hline
\end{tabular}

Powiaty

\begin{tabular}{|r|r|r|r|r|r|r|}
\hline 20084494 & 23551573 & 23077563 & 23681476 & 25388531 & 27959347 & 30696261 \\
\hline 5698648 & 6531299 & 6893850 & 7943152 & 9079007 & 10076314 & 12312508 \\
\hline 9211823 & 10098078 & 10277546 & 10049169 & 10262277 & 10505647 & 11646351 \\
\hline 5174023 & 6922196 & 5906167 & 5689155 & 6047247 & 7377386 & 6737402 \\
\hline
\end{tabular}

\section{Województwa}

\begin{tabular}{|r|r|r|r|r|r|r|}
\hline 19548310 & 15067098 & 16120717 & 17110134 & 14771385 & 16953684 & 18754957 \\
\hline 6314698 & 6672567 & 6303088 & 7154995 & 7777406 & 9024244 & 9911175 \\
\hline 2791935 & 2499054 & 2639245 & 1993115 & 2126913 & 2181271 & 2561097 \\
\hline 10441677 & 5895477 & 7178384 & 7962024 & 4867066 & 5748169 & 6282685 \\
\hline
\end{tabular}

\section{Ogółem jednostki samorządu terytorialnego}

\begin{tabular}{|r|r|r|r|r|r|r|}
\hline 154842460 & 171309128 & 183458281 & 199018949 & 229878741 & 251846419 & 278507114 \\
\hline 75297351 & 83645547 & 91801712 & 103445190 & 113245273 & 124042144 & 135768588 \\
\hline 45295387 & 48347869 & 51257088 & 51343303 & 54280749 & 56429729 & 61745548 \\
\hline 34249722 & 39315712 & 40399481 & 44230456 & 62352719 & 71374546 & 80992978 \\
\hline
\end{tabular}

Źródto: opracowanie własne na podstawie danych ze sprawozdań budżetowych. 
Tabela 5. Struktura dochodów budżetowych jednostek samorządu terytorialnego (w \%)

\begin{tabular}{|l|c|c|c|c|c|c|c|}
\hline \multicolumn{1}{|c|}{ Treść } & $\mathbf{1 9 9 5}$ & $\mathbf{1 9 9 7}$ & $\mathbf{1 9 9 9}$ & $\mathbf{2 0 0 1}$ & $\mathbf{2 0 0 3}$ & $\mathbf{2 0 0 5}$ & $\mathbf{2 0 0 7}$ \\
\hline \multicolumn{7}{|c|}{ Gminy tącznie z miastami na prawach powiatu } \\
\hline Dochody własne & 40,1 & 35,3 & 51,0 & 49,2 & 49,5 & 53,5 & 55,2 \\
\hline Subwencja ogólna & 15,2 & 24,1 & 32,1 & 35,0 & 37,8 & 29,7 & 26,2 \\
\hline Dotacje celowe & 44,7 & 40,6 & 16,9 & 15,8 & 12,7 & 16,8 & 18,6 \\
\hline
\end{tabular}

Gminy bez miast na prawach powiatu

\begin{tabular}{|l|c|c|c|c|c|c|c|}
\hline Dochody własne & 43,1 & 36,2 & 52,7 & 50,4 & 44,7 & 44,9 & 46,6 \\
\hline Subwencja ogólna & 15,1 & 28,4 & 33,6 & 36,2 & 42,2 & 35,1 & 31,3 \\
\hline Dotacje celowe & 41,8 & 35,4 & 13,7 & 13,4 & 13,1 & 20,0 & 22,1 \\
\hline
\end{tabular}

Miasta na prawach powiatu

\begin{tabular}{|l|c|c|c|c|c|c|c|}
\hline Dochody własne & 34,8 & 33,5 & 48,1 & 47,1 & 55,7 & 64,4 & 65,7 \\
\hline Subwencja ogólna & 15,4 & 15,6 & 29,5 & 33,1 & 32,0 & 23,0 & 19,9 \\
\hline Dotacje celowe & 49,8 & 50,9 & 22,4 & 19,8 & 12,3 & 12,6 & 14,4 \\
\hline \multicolumn{7}{|c|}{ Powiaty }
\end{tabular}

\begin{tabular}{|l|c|c|c|c|c|c|c|}
\hline Dochody własne & - & - & 6,1 & 8,3 & 10,4 & 27,2 & 29,6 \\
\hline Subwencja ogólna & - & - & 44,4 & 46,3 & 56,1 & 48,7 & 46,1 \\
\hline Dotacje celowe & - & - & 49,5 & 45,4 & 33,5 & 24,1 & 24,3 \\
\hline
\end{tabular}

Województwa

\begin{tabular}{|l|c|c|c|c|c|c|c|}
\hline Dochody wtasne & - & - & 17,7 & 13,3 & 15,4 & 27,1 & 29,6 \\
\hline Subwencja ogólna & - & - & 34,7 & 34,4 & 33,1 & 48,7 & 46,1 \\
\hline Dotacje celowe & - & - & 47,6 & 52,3 & 51,5 & 24,2 & 24,3 \\
\hline
\end{tabular}

Ogółem jednostki samorządu terytorialnego

\begin{tabular}{|l|c|c|c|c|c|c|c|}
\hline Dochody wtasne & 40,1 & 35,3 & 42,5 & 39,9 & 42,0 & 50,6 & 52,3 \\
\hline Subwencja ogólna & 15,2 & 24,1 & 34,1 & 37,0 & 40,1 & 31,5 & 28,0 \\
\hline Dotacje celowe & 44,7 & 40,6 & 23,4 & 23,1 & 17,9 & 17,9 & 19,7 \\
\hline
\end{tabular}




\begin{tabular}{|l|c|c|c|c|c|c|}
\hline $\mathbf{2 0 0 9}$ & $\mathbf{2 0 1 1}$ & $\mathbf{2 0 1 3}$ & $\mathbf{2 0 1 5}$ & $\mathbf{2 0 1 7}$ & $\mathbf{2 0 1 8}$ & $\mathbf{2 0 1 9}$ \\
\hline \multicolumn{7}{|c|}{ Gminy tącznie z miastami na prawach powiatu } \\
\hline 54,9 & 53,1 & 54,5 & 55,8 & 50,8 & 50,7 & 49,6 \\
\hline 28,9 & 26,9 & 26,6 & 24,8 & 22,1 & 21,1 & 20,7 \\
\hline 16,2 & 20,0 & 18,9 & 19,4 & 27,1 & 28,2 & 29,7 \\
\hline
\end{tabular}

Gminy bez miast na prawach powiatu

\begin{tabular}{|l|l|l|l|l|l|l|}
\hline 46,3 & 45,5 & 48,2 & 49,7 & 43,2 & 43,3 & 43,3 \\
\hline 33,9 & 30,7 & 31,0 & 29,0 & 24,4 & 23,3 & 22,5 \\
\hline 19,8 & 23,8 & 20,8 & 21,3 & 32,4 & 33,4 & 34,2 \\
\hline
\end{tabular}

Miasta na prawach powiatu

\begin{tabular}{|c|c|c|c|c|c|c|}
\hline 66,1 & 63,2 & 62,4 & 63,4 & 61,5 & 61,3 & 58,7 \\
\hline 22,5 & 22,0 & 21,1 & 19,7 & 18,9 & 18,0 & 18,2 \\
\hline 11,4 & 14,8 & 16,5 & 16,9 & 19,6 & 20,7 & 23,1 \\
\hline \multicolumn{7}{|c|}{ Powiaty } \\
\hline 28,3 & 27,7 & 29,9 & 33,6 & 35,8 & 36,0 & 40,1 \\
\hline 45,9 & 42,9 & 44,5 & 42,4 & 40,4 & 37,6 & 37,9 \\
\hline 25,8 & 29,4 & 25,6 & 24,0 & 23,8 & 26,4 & 22,0 \\
\hline \multicolumn{7}{|c|}{ Województwa } \\
\hline 28,4 & 44,3 & 39,1 & 41,8 & 52,7 & 53,2 & 52,8 \\
\hline 45,9 & 16,6 & 16,4 & 11,6 & 14,4 & 12,9 & 13,7 \\
\hline 25,7 & 39,1 & 44,5 & 46,6 & 32,9 & 33,9 & 33,5 \\
\hline \multicolumn{7}{|c|}{ Ogółem jednostki samorządu terytorialnego } \\
\hline 48,6 & 48,8 & 50,1 & 52,0 & 49,3 & 49,3 & 48,7 \\
\hline 29,3 & 28,2 & 27,9 & 25,8 & 23,6 & 22,4 & 22,2 \\
\hline 22,1 & 23,0 & 22,0 & 22,2 & 27,1 & 28,3 & 29,1 \\
\hline
\end{tabular}

Źródto: opracowanie własne na podstawie danych ze sprawozdań budżetowych. 
Tabela 6. Dochody, wydatki i wynik budżetów jednostek samorządowych (w tys. zł)

\begin{tabular}{|c|c|c|c|c|c|c|c|}
\hline Treść & 1995 & 1997 & 1999 & 2001 & 2003 & 2005 & 2007 \\
\hline \multicolumn{8}{|c|}{ Gminy tącznie z miastami na prawach powiatu } \\
\hline Dochody & 19993435 & 39518248 & 51741684 & 60954011 & 63463079 & 82082991 & 103876554 \\
\hline Wydatki & 19828434 & 40504329 & 52796395 & 63704490 & 64791880 & 82328723 & 101951237 \\
\hline Wynik budżetu & 165001 & -986081 & -1054711 & -2750479 & -1328801 & -245732 & 1925317 \\
\hline \multicolumn{8}{|c|}{ Gminy bez miast na prawach powiatu } \\
\hline Dochody & 12696332 & 26371041 & 32353486 & 37286893 & 36046322 & 45813191 & 57003129 \\
\hline Wydatki & 12536474 & 26915311 & 32834851 & 38567975 & 36595278 & 45837492 & 56074124 \\
\hline Wynik budżetu & 159858 & -544270 & -481365 & -1281082 & -548956 & -24301 & 929005 \\
\hline \multicolumn{8}{|c|}{ Miasta na prawach powiatu } \\
\hline Dochody & 7297103 & 13147207 & 19388198 & 23667118 & 27416757 & 36269800 & 46873425 \\
\hline Wydatki & 7291960 & 13589018 & 19961544 & 25136515 & 28196602 & 36491231 & 45877113 \\
\hline Wynik budżetu & 5143 & -441811 & -573346 & -1469397 & -779845 & -221431 & 996312 \\
\hline \multicolumn{8}{|c|}{ Powiaty } \\
\hline Dochody & - & - & 9847402 & 14041104 & 11111621 & 13762684 & 16154756 \\
\hline Wydatki & - & - & 9784883 & 14292712 & 11449737 & 13890877 & 16069643 \\
\hline Wynik budżetu & - & - & 62519 & -251608 & -338116 & -128193 & 58113 \\
\hline \multicolumn{8}{|c|}{ Województwa } \\
\hline Dochody & - & - & 3288427 & 4599534 & 4565750 & 7066206 & 11348892 \\
\hline Wydatki & - & - & 3264607 & 4737055 & 4712741 & 7587500 & 11092206 \\
\hline Wynik budżetu & - & - & 23820 & -137521 & -146991 & -521294 & 256686 \\
\hline \multicolumn{8}{|c|}{ Ogółem jednostki samorządu terytorialnego } \\
\hline Dochody & 19993435 & 39518248 & 64877513 & 79594649 & 79140450 & 102911881 & 131380202 \\
\hline Wydatki & 19828434 & 40504329 & 65845885 & 82734257 & 80954358 & 103807100 & 129113086 \\
\hline Wynik budżetu & 165001 & -986081 & -968372 & -3139608 & -1813908 & -895219 & 2267116 \\
\hline
\end{tabular}




\begin{tabular}{|c|c|c|c|c|c|c|c|}
\hline 2009 & 2011 & 2013 & 2015 & 2017 & 2018 & 2019 \\
\hline \multicolumn{7}{|c|}{ Gminy tącznie z miastami na prawach powiatu } \\
\hline 115209656 & 132690457 & 144260001 & 158227339 & 189718825 & 206933387 & 229055896 \\
\hline 126203717 & 141197341 & 144395093 & 155768542 & 190488499 & 214147385 & 232202313 \\
\hline-10994061 & -8506884 & -135092 & 2458797 & -769674 & -7213998 & -3146417 \\
\hline
\end{tabular}

\section{Gminy bez miast na prawach powiatu}

\begin{tabular}{|r|r|r|r|r|r|r|}
\hline 64882149 & 75830680 & 80043418 & 87667235 & 111189285 & 121425597 & 135161525 \\
\hline 70002631 & 79686866 & 79442533 & 85944374 & 111984447 & 127132773 & 135316857 \\
\hline-5120482 & -3856186 & 600885 & 1722861 & -795162 & -5707176 & -155332 \\
\hline
\end{tabular}

\section{Miasta na prawach powiatu}

\begin{tabular}{|r|r|r|r|r|r|r|}
\hline 50327507 & 56859777 & 64216583 & 70560104 & 78529540 & 85507790 & 93894371 \\
\hline 56201086 & 61510475 & 64952560 & 69824168 & 78504052 & 87014612 & 96885456 \\
\hline-5873579 & -4650698 & -735977 & 735936 & 25488 & -1506822 & -2991085 \\
\hline
\end{tabular}

\section{Powiaty}

\begin{tabular}{|r|r|r|r|r|r|r|}
\hline 20084494 & 23551573 & 23077563 & 23681476 & 25388531 & 27959347 & 30696261 \\
\hline 21155788 & 24058772 & 22916546 & 23444107 & 25360416 & 28656571 & 29630698 \\
\hline-1071294 & -507199 & 161017 & 237369 & 28115 & -697224 & 1065563 \\
\hline
\end{tabular}

\section{Województwa}

\begin{tabular}{|r|r|r|r|r|r|r|}
\hline 19548310 & 15067098 & 16120717 & 17110134 & 14771385 & 16953684 & 18754957 \\
\hline 20468690 & 16338629 & 16527004 & 17202651 & 14317429 & 16582312 & 18375964 \\
\hline-920380 & -1271531 & -406287 & -92517 & 453956 & 371372 & 378993 \\
\hline
\end{tabular}

\section{Ogółem jednostki samorządu terytorialnego}

\begin{tabular}{|r|r|r|r|r|r|r|}
\hline 154842460 & 171309128 & 183458281 & 199018949 & 229878741 & 251846418 & 278507114 \\
\hline 167828195 & 181594742 & 183838643 & 196415300 & 230166344 & 259386268 & 280208975 \\
\hline-12985735 & -10285614 & -380362 & 2603649 & -287603 & -7539850 & -1701861 \\
\hline
\end{tabular}

Źródto: opracowanie własne na podstawie danych ze sprawozdań budżetowych. 
Tabela 7. Zadłużenie i obsługa długu jednostek samorządu terytorialnego (w tys. zł)

\begin{tabular}{|c|c|c|c|c|c|c|c|}
\hline Treść & 2005 & 2006 & 2007 & 2008 & 2009 & 2010 & 2011 \\
\hline \multicolumn{8}{|c|}{ Gminy łącznie z miastami na prawach powiatu } \\
\hline Obsługa dtugu & 846195 & 725476 & 838409 & 1081135 & 1134143 & 1517765 & 2223821 \\
\hline Zadłużenie & 18482762 & 20882449 & 21217248 & 235963343 & 33340870 & 45367134 & 54064541 \\
\hline \multicolumn{8}{|c|}{ Gminy bez miast na prawach powiatu } \\
\hline Obsługa dtugu & 345519 & 300975 & 360767 & 481403 & 501847 & 698353 & 1089661 \\
\hline Zadłużenie & 8067277 & 9586249 & 9958558 & 10821046 & 14611051 & 21929612 & 25989644 \\
\hline \multicolumn{8}{|c|}{ Miasta na prawach powiatu } \\
\hline Obsługa dtugu & 500676 & 424501 & 477642 & 599732 & 632296 & 819412 & 1134160 \\
\hline Zadłużenie & 10415485 & 11296200 & 11258690 & 12775288 & 18729819 & 23437522 & 28074897 \\
\hline \multicolumn{8}{|c|}{ Powiaty } \\
\hline Obsługa dtugu & 115348 & 84841 & 112375 & 153236 & 150580 & 194159 & 280807 \\
\hline Zadtużenie & 1815593 & 2492694 & 2639529 & 2888909 & 3907312 & 5435587 & 6136854 \\
\hline \multicolumn{8}{|c|}{ Województwa } \\
\hline Obsługa dtugu & 35214 & 29118 & 43315 & 81490 & 115380 & 139585 & 206738 \\
\hline Zadłużenie & 882621 & ź1 573979 & 2019320 & 2289451 & 3046162 & 4291150 & 5555073 \\
\hline \multicolumn{8}{|c|}{ Ogółem jednostki samorządu terytorialnego } \\
\hline Obsługa dtugu & 996757 & 839435 & 994099 & 1315861 & 1400103 & 1851509 & 2711366 \\
\hline Zadłużenie & 21180976 & 24949122 & 25876097 & 28774694 & 40294344 & 55093871 & 65756468 \\
\hline
\end{tabular}




\begin{tabular}{|l|c|c|c|c|c|c|c|}
\hline 2012 & 2013 & 2014 & 2015 & 2016 & 2017 & 2018 & 2019 \\
\hline \begin{tabular}{|c|c|c|r|r|rc|c|}
\hline \multicolumn{7}{|c|}{ Gminy tącznie z miastami na prawach powiatu } \\
\hline 2865891 & 2333030 & 2018235 & 1677028 & 1587172 & 1537952 & 1554036 & 1715920 \\
\hline 55746540 & 56656420 & 58882589 & 58635958 & 56685251 & 57205494 & 63664781 & 69470240 \\
\hline
\end{tabular}
\end{tabular}

\section{Gminy bez miast na prawach powiatu}

\begin{tabular}{|r|r|r|r|r|r|r|r|}
\hline 1399730 & 1100331 & 925212 & 771478 & 701271 & 663088 & 701980 & 830292 \\
\hline 26167852 & 25771862 & 26436163 & 25425678 & 23863530 & 24838221 & 30095513 & 32369253 \\
\hline
\end{tabular}

Miasta na prawach powiatu

\begin{tabular}{|r|r|r|r|r|r|r|r|}
\hline 1466161 & 1232699 & 1093023 & 905550 & 885901 & 874864 & 852056 & 885628 \\
\hline 29578688 & 30884558 & 32446426 & 33210280 & 32821721 & 32367273 & 33569268 & 37100987 \\
\hline
\end{tabular}

Powiaty

\begin{tabular}{|r|r|r|r|r|r|r|r|}
\hline 341251 & 257253 & 211398 & 171500 & 156005 & 150543 & 155062 & 180155 \\
\hline 5975086 & 5877616 & 5943224 & 5841183 & 5565814 & 5628367 & 6467456 & 6580247 \\
\hline
\end{tabular}

\section{Województwa}

\begin{tabular}{|r|r|r|r|r|r|r|r|}
\hline 282385 & 243172 & 210084 & 188744 & 184637 & 170080 & 150614 & 139069 \\
\hline 6112889 & 6625077 & 7284058 & 7154539 & 6768869 & 6092215 & 5983561 & 5985551 \\
\hline
\end{tabular}

\section{Ogótem jednostki samorządu terytorialnego}

\begin{tabular}{|r|r|r|r|r|r|r|r|}
\hline 3489527 & 2833455 & 2439717 & 2037272 & 1927814 & 1858575 & 1859712 & 2035144 \\
\hline 67834515 & 69159113 & 72109871 & 71634680 & 69019934 & 68926076 & 76115798 & 82036038 \\
\hline
\end{tabular}

Źródto: opracowanie własne na podstawie danych ze sprawozdań budżetowych. 
Tabela 8. Wydatki budżetu jednostek samorządu terytorialnego (w tys. zt)

\begin{tabular}{|c|c|c|c|c|c|c|c|}
\hline Treść & 1995 & 1997 & 1999 & 2001 & 2003 & 2005 & 2007 \\
\hline \multicolumn{8}{|c|}{ Gminy bez miast na prawach powiatu } \\
\hline Wydatki & 12536474 & 26915311 & 32834851 & 38567975 & 36595278 & 45837492 & 56074124 \\
\hline bieżące & 9127381 & 20003915 & 25573779 & 31103950 & 30344432 & 37488094 & 45508131 \\
\hline majątkowe & 3409093 & 6911396 & 7261072 & 7464025 & 6250846 & 8349398 & 10565993 \\
\hline \multicolumn{8}{|c|}{ Miasta na prawach powiatu } \\
\hline Wydatki & 7291960 & 13589018 & 19961544 & 25136515 & 28196602 & 36491231 & 45877113 \\
\hline bieżące & 6043308 & 10819641 & 16329877 & 21113603 & 24457054 & 30600754 & 35550439 \\
\hline majątkowe & 1248652 & 2769377 & 3631667 & 4022912 & 3739548 & 5890477 & 10326674 \\
\hline \multicolumn{8}{|c|}{ Gminy tącznie z miastami na prawach powiatu } \\
\hline Wydatki & 19828434 & 40504329 & 52796395 & 63704490 & 64791880 & 82328723 & 101951237 \\
\hline bieżące & 15170689 & 30823556 & 41903656 & 52217553 & 54801486 & 68088848 & 81058570 \\
\hline majątkowe & 4657745 & 9680773 & 10892739 & 11486937 & 9990394 & 14239875 & 20892667 \\
\hline \multicolumn{8}{|c|}{ Powiaty } \\
\hline Wydatki & - & - & 9784883 & 14292712 & 11449737 & 13890877 & 16069643 \\
\hline bieżące & - & - & 9151457 & 13035482 & 10440438 & 12269593 & 13962497 \\
\hline majątkowe & - & - & 633426 & 1257230 & 1009299 & 1621284 & 2107146 \\
\hline \multicolumn{8}{|c|}{ Województwa } \\
\hline Wydatki & - & - & 3264607 & 4737055 & 4712741 & 7587500 & 11092206 \\
\hline bieżące & - & - & 2165476 & 3409802 & 3141923 & 5018285 & 7025544 \\
\hline majątkowe & - & - & 1099131 & 1327253 & 1570818 & 2569215 & 4066662 \\
\hline \multicolumn{8}{|c|}{ Ogółem jednostki samorządu terytorialnego } \\
\hline Wydatki & 19828434 & 40504329 & 65845885 & 82734257 & 80954358 & 103807100 & 129113086 \\
\hline bieżące & 15170689 & 30823556 & 53220589 & 68662837 & 68383847 & 85376726 & 102046611 \\
\hline majątkowe & 4657745 & 9680773 & 12625296 & 14071420 & 12570511 & 18430374 & 27066475 \\
\hline
\end{tabular}




\begin{tabular}{|c|c|c|c|c|c|c|c|}
\hline $\mathbf{2 0 0 9}$ & $\mathbf{2 0 1 1}$ & $\mathbf{2 0 1 3}$ & $\mathbf{2 0 1 5}$ & $\mathbf{2 0 1 7}$ & $\mathbf{2 0 1 8}$ & $\mathbf{2 0 1 9}$ \\
\hline \multicolumn{7}{|c|}{ Gminy bez miast na prawach powiatu } \\
\hline 70002631 & 79686866 & 79442533 & 85944374 & 111984447 & 127132774 & 135316857 \\
\hline 53824797 & 61434096 & 66270298 & 71455139 & 95588525 & 100890845 & 112419576 \\
\hline 16177834 & 18252770 & 13172235 & 14489235 & 16395922 & 26241929 & 22897281 \\
\hline
\end{tabular}

Miasta na prawach powiatu

\begin{tabular}{|r|r|r|r|r|r|r|}
\hline 56201086 & 61510475 & 64952560 & 69824168 & 78504052 & 87014612 & 96885456 \\
\hline 43287495 & 48443326 & 52534500 & 56927594 & 68095739 & 72311060 & 80987724 \\
\hline 12913591 & 13067149 & 12418060 & 12896574 & 10408313 & 14703552 & 15897732 \\
\hline
\end{tabular}

Gminy tącznie z miastami na prawach powiatu

\begin{tabular}{|r|r|r|r|r|r|r|}
\hline 126203717 & 141197341 & 144395093 & 155768542 & 190488499 & 214147386 & 232202313 \\
\hline 97112292 & 109877422 & 118804798 & 128382733 & 163684264 & 173201905 & 193407300 \\
\hline 29091425 & 31319919 & 25590295 & 27385809 & 26804235 & 40945481 & 38795013 \\
\hline
\end{tabular}

\section{Powiaty}

\begin{tabular}{|r|r|r|r|r|r|r|}
\hline 21155788 & 24058772 & 22916546 & 23444107 & 25360416 & 28656571 & 29630697 \\
\hline 17080125 & 19556760 & 20062433 & 20017020 & 21277047 & 22673787 & 24341254 \\
\hline 4075663 & 4502012 & 2854113 & 3427087 & 4083369 & 5982784 & 5289443 \\
\hline
\end{tabular}

Województwa

\begin{tabular}{|r|r|r|r|r|r|r|}
\hline 20468690 & 16338629 & 16527004 & 17202651 & 14317429 & 16582312 & 18375964 \\
\hline 10509701 & 9726371 & 9964705 & 9439662 & 9990397 & 10632639 & 11408055 \\
\hline 9958989 & 6612258 & 6562299 & 7762989 & 4327032 & 5949673 & 6967909 \\
\hline
\end{tabular}

\section{Ogółem jednostki samorządu terytorialnego}

\begin{tabular}{|r|r|r|r|r|r|r|}
\hline 167828195 & 181594742 & 183838643 & 196415300 & 230166344 & 259386269 & 280208974 \\
\hline 124702118 & 139160553 & 148831936 & 157839415 & 194951708 & 206508331 & 229156609 \\
\hline 43126077 & 42434189 & 35006707 & 38575885 & 35214636 & 52877938 & 51052365 \\
\hline
\end{tabular}

Źródto: opracowanie własne na podstawie danych ze sprawozdań budżetowych jednostek samorządu terytorialnego. 
Tabela 9. Struktura wydatków budżetu jednostek samorządu terytorialnego (w \%)

\begin{tabular}{|l|r|r|r|r|r|r|r|}
\hline \multicolumn{1}{|c|}{ Treść } & $\mathbf{1 9 9 5}$ & $\mathbf{1 9 9 7}$ & $\mathbf{1 9 9 9}$ & $\mathbf{2 0 0 1}$ & $\mathbf{2 0 0 3}$ & $\mathbf{2 0 0 5}$ & $\mathbf{2 0 0 7}$ \\
\hline \multicolumn{7}{|c|}{ Gminy bez miast na prawach powiatu } \\
\hline Wydatki & 100,0 & 100,0 & 100,0 & 100,0 & 100,0 & 100,0 & 100,0 \\
\hline bieżące & 72,8 & 74,3 & 77,9 & 80,6 & 82,9 & 81,8 & 81,2 \\
\hline majątkowe & 27,2 & 25,7 & 22,1 & 19,4 & 17,1 & 18,2 & 18,8 \\
\hline \multicolumn{7}{|c|}{ Miasta na prawach powiatu } \\
\hline Wydatki & 100,0 & 100,0 & 100,0 & 100,0 & 100,0 & 100,0 & 100,0 \\
\hline bieżące & 82,9 & 79,6 & 81,8 & 84,0 & 86,7 & 83,9 & 77,5 \\
\hline majątkowe & 17,1 & 20,4 & 18,2 & 16,0 & 13,3 & 16,1 & 22,5 \\
\hline
\end{tabular}

Gminy tącznie z miastami na prawach powiatu

\begin{tabular}{|l|r|r|r|r|r|r|r|}
\hline Wydatki & 100,0 & 100,0 & 100,0 & 100,0 & 100,0 & 100,0 & 100,0 \\
\hline bieżące & 76,5 & 76,1 & 79,4 & 82,0 & 84,6 & 82,7 & 79,5 \\
\hline majątkowe & 23,5 & 23,9 & 20,6 & 18,0 & 15,4 & 17,3 & 20,5 \\
\hline
\end{tabular}

Powiaty

\begin{tabular}{|l|r|r|r|r|r|r|r|}
\hline Wydatki & - & - & 100,0 & 100,0 & 100,0 & 100,0 & 100,0 \\
\hline bieżące & - & - & 93,5 & 91,2 & 91,2 & 88,3 & 86,9 \\
\hline majątkowe & - & - & 6,5 & 8,8 & 8,8 & 11,7 & 13,1 \\
\hline
\end{tabular}

Województwa

\begin{tabular}{|l|r|r|r|r|r|r|r|}
\hline Wydatki & - & - & 100,0 & 100,0 & 100,0 & 100,0 & 100,0 \\
\hline bieżące & - & - & 66,3 & 72,0 & 66,7 & 66,1 & 63,3 \\
\hline majątkowe & - & - & 33,7 & 28,0 & 33,3 & 33,9 & 36,7 \\
\hline
\end{tabular}

Ogółem jednostki samorządu terytorialnego

\begin{tabular}{|l|r|r|r|r|r|r|r|}
\hline Wydatki & 100,0 & 100,0 & 100,0 & 100,0 & 100,0 & 100,0 & 100,0 \\
\hline bieżące & 76,5 & 76,1 & 80,8 & 83,0 & 84,5 & 82,2 & 79,0 \\
\hline majątkowe & 23,5 & 23,9 & 19,2 & 17,00 & 15,5 & 17,8 & 21,0 \\
\hline
\end{tabular}




\begin{tabular}{|r|r|r|r|r|r|r|}
\hline $\mathbf{2 0 0 9}$ & $\mathbf{2 0 1 1}$ & $\mathbf{2 0 1 3}$ & $\mathbf{2 0 1 5}$ & $\mathbf{2 0 1 7}$ & $\mathbf{2 0 1 8}$ & $\mathbf{2 0 1 9}$ \\
\hline 100,0 & 100,0 & 100,0 & 100,0 & 100,0 & 100,0 & 100,0 \\
\hline 76,9 & 77,1 & 83,4 & 83,1 & 85,4 & 79,4 & 83,1 \\
\hline 23,1 & 22,9 & 16,6 & 16,9 & 14,6 & 20,6 & 16,9 \\
\hline
\end{tabular}

Miasta na prawach powiatu

\begin{tabular}{|r|r|r|r|r|r|r|}
\hline 100,0 & 100,0 & 100,0 & 100,0 & 100,0 & 100,0 & 100,0 \\
\hline 77,0 & 78,8 & 80,9 & 81,5 & 86,7 & 83,1 & 83,6 \\
\hline 23,0 & 21,2 & 19,1 & 18,5 & 13,3 & 16,9 & 16,4 \\
\hline
\end{tabular}

Gminy tącznie z miastami na prawach powiatu

\begin{tabular}{|r|r|r|r|r|r|r|}
\hline 100,0 & 100,0 & 100,0 & 100,0 & 100,0 & 100,0 & 100,0 \\
\hline 76,9 & 77,8 & 82,3 & 82,4 & 85,9 & 80,9 & 83,3 \\
\hline 23,1 & 22,2 & 17,7 & 17,6 & 14,1 & 19,1 & 16,7 \\
\hline 100,0 & 100,0 & 100,0 & 100,0 & 100,0 & 100,0 & 100,0 \\
\hline 80,7 & 81,3 & 87,5 & 85,4 & 83,9 & 79,1 & 82,1 \\
\hline 19,3 & 18,7 & 12,5 & 14,6 & 16,1 & 20,9 & 17,9 \\
\hline
\end{tabular}

Województwa

\begin{tabular}{|r|r|r|r|r|r|r|}
\hline 100,0 & 100,0 & 100,0 & 100,0 & 100,0 & 100,0 & 100,0 \\
\hline 51,3 & 59,5 & 60,3 & 54,9 & 69,8 & 64,1 & 62,1 \\
\hline 48,7 & 40,5 & 39,7 & 45,1 & 30,2 & 35,9 & 37,9 \\
\hline \multicolumn{7}{|c|}{ Ogółem jednostki samorządu terytorialnego } \\
\hline 100,0 & 100,0 & 100,0 & 100,0 & 100,0 & 100,0 & 100,0 \\
\hline 74,3 & 76,6 & 81,0 & 80,4 & 84,7 & 79,6 & 81,8 \\
\hline 25,7 & 23,4 & 19,0 & 19,6 & 15,3 & 20,4 & 18,2 \\
\hline
\end{tabular}

Źródło: opracowanie własne na podstawie danych ze sprawozdań budżetowych jednostek samorządu terytorialnego. 
Tabela 10. Wynik na działalności bieżącej w budżetach jednostek samorządu terytorialnego - nadwyżka operacyjna (w tys. zł)

\begin{tabular}{|l|c|c|c|c|c|c|c|c|}
\hline \multicolumn{1}{|c|}{ Treść } & $\mathbf{2 0 0 7}$ & $\mathbf{2 0 0 9}$ & $\mathbf{2 0 1 1}$ & $\mathbf{2 0 1 3}$ & $\mathbf{2 0 1 5}$ & $\mathbf{2 0 1 7}$ & $\mathbf{2 0 1 8}$ & $\mathbf{2 0 1 9}$ \\
\hline $\begin{array}{l}\text { Gminy } \\
\text { bez miast } \\
\text { na prawach } \\
\text { powiatu }\end{array}$ & 7197145 & 6191256 & 5426440 & 7340436 & 8730744 & 10405869 & 10814688 & 11376846 \\
\hline $\begin{array}{l}\text { Miasta } \\
\text { na prawach } \\
\text { powiatu }\end{array}$ & 6793425 & 2981699 & 2787569 & 4152056 & 5849383 & 6336539 & 7162087 & 6343375 \\
\hline $\begin{array}{l}\text { Gminy } \\
\text { z miastami } \\
\text { na prawach } \\
\text { powiatu }\end{array}$ & 13990570 & 9172955 & 8214009 & 11492492 & 14580127 & 16742408 & 17976775 & 17720221 \\
\hline Powiaty & 975670 & 883330 & 1267534 & 1255944 & 1613222 & 2073145 & 2057714 & 2762092 \\
\hline $\begin{array}{l}\text { Wojewódz- } \\
\text { twa }\end{array}$ & 2756764 & 1903531 & 1512455 & 1588353 & 2034265 & 2362887 & 3087521 & 3673312 \\
\hline
\end{tabular}

Źródto: opracowanie własne na podstawie danych ze sprawozdań budżetowych jednostek samorządu terytorialneo. 


\section{Spis tabel}

Tabela 1. Wybrane państwa OECD wg poziomu decentralizacji (podsektor subnational government; 2015)

Tabela 2. Liczba samorządów z deficytem na działalności bieżącej w latach 2012-2019

Tabela 3. Ocena kondycji gospodarki finansowej jednostki samorządowej

Tabela 4. Wielkość dochodów budżetowych jednostek samorządu terytorialnego (w tys. zt)

Tabela 5. Struktura dochodów budżetowych jednostek samorządu terytorialnego (w \%)

Tabela 6. Dochody, wydatki i wynik budżetów jednostek samorządowych (w tys. zt)

Tabela 7. Zadłużenie i obsługa długu jednostek samorządu terytorialnego (w tys. zt)

Tabela 8. Wydatki budżetu jednostek samorządu terytorialnego (w tys. zł)

Tabela 9. Struktura wydatków budżetu jednostek samorządu terytorialnego (w \%)

Tabela 10. Wynik na działalności bieżącej w budżetach jednostek samorządu terytorialnego - nadwyżka operacyjna (w tys. zt) 